\title{
Višeslojno naselje Gornja Tuzla u hronologiji neolita sjeveroistočne Bosne
}

\section{Brigić, Dženan}

\section{Doctoral thesis / Disertacija}

2020

Degree Grantor / Ustanova koja je dodijelila akademski / stručni stupanj: University of Zagreb, University of Zagreb, Faculty of Humanities and Social Sciences / Sveučilište u Zagrebu, Filozofski fakultet

https://doi.org/10.17234/diss.2020.344966

Permanent link / Trajna poveznica: https://urn.nsk.hr/urn:nbn:hr:131:675053

Rights / Prava: In copyright/Zaštićeno autorskim pravom.

Download date / Datum preuzimanja: 2023-04-26

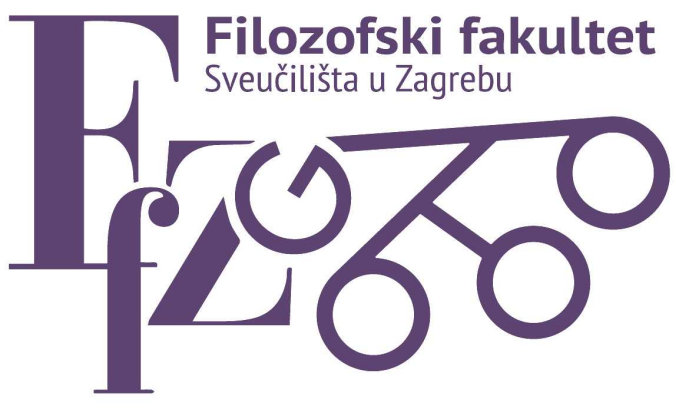

Repository / Repozitorij:

ODRAZ - open repository of the University of Zagreb Faculty of Humanities and Social Sciences
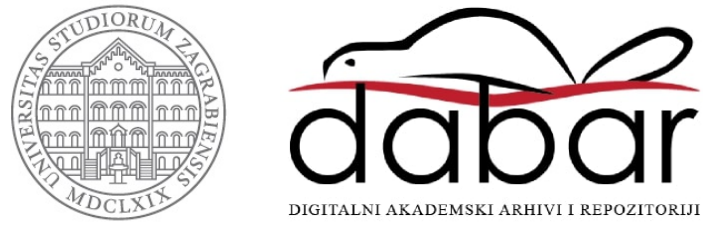


\section{(c) \\ Sveučilište u Zagrebu}

Filozofski fakultet

Dženan Brigić

\section{VIŠESLOJNO NASELJE GORNJA TUZLA U HRONOLOGIJI NEOLITA SJEVEROISTOČNE BOSNE}

DOKTORSKI RAD

Zagreb, 2020 


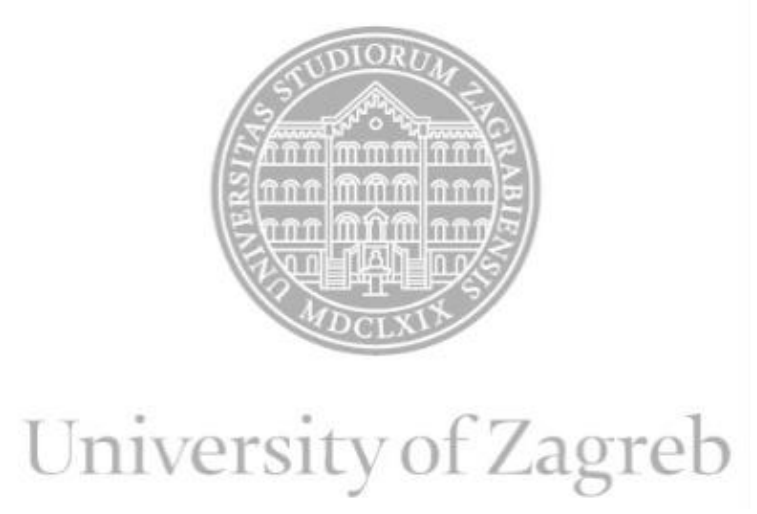

Faculty of Humanities and Social Sciences

Dženan Brigić

\section{MULTILAYERED SETTLEMENT OF GORNJA TUZLA IN THE NEOLITHIC CHRONOLOGY OF NORTHEASTERN BOSNIA}

Doctoral Thesis

Zagreb, 2020 


\section{Podatci o mentoru}

Marcel Burić rođen je 1973. godine u Darmstadtu u Njemačkoj. Godine 1993. upisao je jednopredmetni studij arheologije na Odsjeku za arheologiju Filozofskog fakulteta Sveučilišta u Zagrebu. Dobitnik je Rektorove nagrade Sveučilišta u Zagrebu za 2000. godinu, a diplomirao je 2001. godine. U razdoblju od 2003 - 2009. godine bio je zaposlen na Odsjeku za arheologiju Filozofskog fakulteta Sveučilišta u Zagrebu kao znanstveni novak na projektu Ministarstva znanosti, obrazovanja i sporta Republike Hrvatske "Sirovine i tehnologije prapovijesnih kultura u Hrvatskoj / Raw materials and technologies of the prehistoric cultures in Croatia" (130-2690680-0987) koji je vodila prof. dr. sc. Tihomila Težak-Gregl. Godine 2009. stekao je akademski stupanj doktora nauka, doktoriravši s temom "Vinčanska kultura i njezin utjecaj na neolitik istočne Hrvatske" pod mentorstvom prof. dr. sc. Tihomile TežakGregl. Iste godine prelazi u saradničko zvanje višeg asistenta. U 2011. godini izabran je u naučno zvanje znanstvenog suradnika u naučnom području humanističkih nauka, polje arheologija, grana prahistorijska arheologija. Godine 2012. postaje član Vijeća Filozofskog fakulteta Sveučilišta u Zagrebu. U 2013. godini izabran je u naučno-nastavno zvanje docenta na Odsjeku za arheologiju Filozofskog fakulteta Sveučilišta u Zagrebu.

Od akademske godine 2003/2004. do danas, redovno sudjeluje u izvođenju nastave na preddiplomskom i diplomskom studiju arheologije Filozofskog fakulteta Sveučilišta u Zagrebu, a od 2009. godine sudjeluje u nastavi na poslijediplomskom doktorskom studiju arheologije na istome Fakultetu. Mentor je u izradi diplomskih i doktorskih radova na Sveučilištu u Zagrebu. Voditelj je naučnog projekta Ministarstva kulture Republike Hrvatske "Bapska- Gradac; Iskopavanje kasnoneolitičkog višeslojnog lokaliteta", koji traje od 2006. godine do danas.

Bio je suorganizator međunarodnog naučnog projekta "Archaeometrical research of lithic raw materials for Early Neolithic prehistoric communities with the help of Prompt Gamma Activation Analysis, with special regard to radiolarites and obsidian" (hrvatsko-mađarski bilateralni projekt). Također je saradnik na više međunarodnih znanstvenih projekata. Od 2010. godine saradnik je na projektu "CHARISMA: FIXLAB the platforms of European large and medium scale facilities - PLATFORM B". Taj projekt sufinancira Europska komisija u okviru programa "Research Infrastructures of the 'Capacities' Programme GA No. FP7-228330", Wigner Research Centre for Physics (BNC-WIGNER) i Centre for Energy Research of Hungarian Academy of Sciences, Budapest. Dio je programa "PGAA research 
on obsidian and radiolarite raw materials from archaeological contexts in Croatia and Bosnia and Herzegovina." Od 2010. godine saradnik je i na projektu Ministarstva nauka Republike Srbije "Društvo, duhovno-materijalna kultura i komunikacije u praistoriji i ranoj istoriji Balkana / Society, Spiritual and Material Culture and Communications in Prehistory and Early History of Balkans" (177012) koji vodi prof. dr. sc. Nenad Tasić.

Održao je i niz pozvanih predavanja na inozemnim naučnim ustanovama. U maju 2007. godine održao je pozvano predavanje pod naslovom "Neolithic of Continetal Croatia as part of the Late Neolithic of SE Europe. The Late Neolithic Tell in Bapska and R. R. Schimdt" na Institut für Ur- und Frühgeschichte und Archäologie des Mittelalters, Abteilung für Jüngere Urgeschichte und Früchgeschichte Sveučilišta u Tübingenu. U aprilu 2008. godine održao je pozvano predavanje pod naslovom "Early to Late Neolithic Shift in Eastern Croatia" na Dipartimento di Archeologia e Storia delle Arti Sveučilišta u Sieni. U maju 2010. godine održao je pozvano predavanje pod naslovom "The Neolithic of Croatia and problems of the absolute chronology" na Odsjeku za povijest i arheologiju Aristotelovog sveučilišta u Solunu. U novembru 2011. godine održao je pozvano predavanje pod naslovom "Neolithic Period in Croatia: Current state of research. Case study: Tell in Bapska in frame of Late Neolithic of Eastern Croatia" na Das Institut für Ur- und Frühgeschichte Sveučilišta u Beču. Sudjelovao je na brojnim domaćim i inozemnim naučnim konferencijama. Organizator je međunarodne naučne konferencije "Northern Greece and Southeastern Europe during the Neolithic Period. An Interaction Zone", održane 26 - 29. juna 2014. u Solunu, na kojoj je sudjelovao i kao predavač.

Recenzent je znanstvenih priloga u hrvatskim naučnim arheološkim časopisima (Prilozi Instituta za arheologiju u Zagrebu, Zagreb; Diadora, Zadar; Asseria, Zadar; Opuscula Archaeologica, Zagreb), kao i u jednom inozemnom naučnom arheološkom časopisu (Anthropologie, Prag).

Područje njegovog naučnog interesa obuhvata arheologiju neolita i eneolita. 


\section{SAŽETAK}

Ova disertacija bavi se istraživanjem prostora Bosne i Hercegovine u neolitskom periodu, sa posebnim osvrtom na prostor sjeveroistočne Bosne, odnosno lokalitet Gornja Tuzla. Navedeni je prostor bio dominatno pod uticajem vinčanske kulture, a starčevačka je pripadnost ustanovljena samo na lokalitetu Gornja Tuzla. Prema tome, vinčanska je kultura imala izuzetno jak uticaj na prostor sjeveroistočne Bosne u odnosu na starčevačku, ostavivši iza sebe mnogo naselja sa dužim ili kraćim periodom trajanja. Vremenski okvir kojim se ovaj rad bavi jeste period druge polovice srednjeg te cjelokupan period mlađeg neolita na prostoru Bosne odnosno istočne Hrvatske i zapadne Srbije (područje prostiranja starčevačke i vinčanske kulture).

Rad polazi od pretpostavke da su geološke promjene imale znatan uticaj na genezu tla sjeveroistočne Bosne, geografske odlike tuzlanskog bazena i stvaranje solnih formacija. Upravo taj geološki proces, koji je doveo do stvaranja solnih formacija na prostoru tuzlanskog bazena, imao je ključnu ulogu pri naseljavanju starčevačke populacije, kasnije i vinčanske, na lokalitet Gornja Tuzla. Bogatstvo tuzlanskog bazena rudama soli omogućilo je neolitskim zajednicama da se bave proizvodnjom soli koja je imala veoma bitnu ulogu u njihovom životu.

Izvršena je analiza materijala iskopanog 1958. godine u Gornjoj Tuzli (voditelja Borivoja Čovića), koji je deponovan u Zemaljski muzej Bosne i Hercegovine u Sarajevu. Analiziran je i materijal sa iskopavanja provedenog 2007 - 2009. godine, kao i sa iskopavanja provedenog 2018. godine, sa ciljem komparacije i dodatne analize materijala. Komparacijom iskopanog materijala sa lokaliteta Gornja Tuzla ustanovljena je kulturna pripadnost Gornje Tuzle i njenih stratuma sa njihovim specifičnostima. Dosad je objavljeno pet datuma radiokarbonske analize iz slojeva Gornje Tuzle, na osnovu čega je ustanovljena hronološka determinacija u odnosu na ostala neolitska naselja sjeveroistočne Bosne.

Ključne riječi: neolit, Bosna i Hercegovina, sjeveroistočna Bosna, solna formacija, Gornja Tuzla, keramika, Starčevo, Vinča, hronologija 


\section{SUMMARY}

This dissertation explores the neolithic period in Bosnia and Herzegovina, with special reference to northeastern Bosnia and the settlement Gornja Tuzla. This area was under the influence of the Vinča culture, with a Starčevo presence determined only in Gornja Tuzla. According to this, compared to Starčevo, the Vinča culture had exceptional influence on northeastern Bosnia, leaving many settlements with longer or shorter periods of duration. The time frame that this dissertation explores is the second half of the middle, and the entire period of the younger neolithic period in Bosnia, in relation with eastern Croatia and western Serbia (Starčevo and Vinča culture).

This dissertation is based on the hypotesis that geological changes had significant influence on the genesis of soil in northeastern Bosnia, geographical features of Tuzla basin and creation of salt formations. This geological process, which led to the creation of salt formations in the Tuzla basin, had a key role in the process of inhabiting the area of Gornja Tuzla by Starčevo and later Vinča populations. The wealth of salt ore in the Tuzla basin enabled production of this mineral to the neolithic communities, and this an extremely important role in their lives.

An analysis of material excavated in 1958 by Borivoj Čović in Gornja Tuzla, which is curated in the National museum of Bosnia and Herzegovina, has been performed. Also, an analysis of material excavated during 2007-2008, and 2018, has been performed. Comparing the excavated material in Gornja Tuzla from these three excavations, a cultural affiliation of Gornja Tuzla with its layers and their specific features has been established. So far, five samples from Gornja Tuzla layers have been analysed. Results of radiocarbon analysis allow better information about the chronological determination of Gornja Tuzla in relationship to the rest of the neolithic settlements of northeastern Bosnia.

Key words: neolithic, Bosnia and Herzegovina, northeastern Bosnia, salt formation, Gornja Tuzla, pottery, Starčevo, Vinča, chronology 


\section{SADRŽAJ}

I

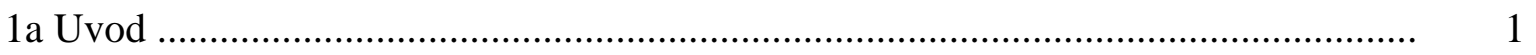

1b Geografske odrednice sjeveroistočne Bosne .................................................... 4

II

2a Povijest istraživanja neolitskih lokaliteta Bosne i Hercegovine

III

Neolit BiH - vanjski utjecaji na formiranje kulturnih grupa

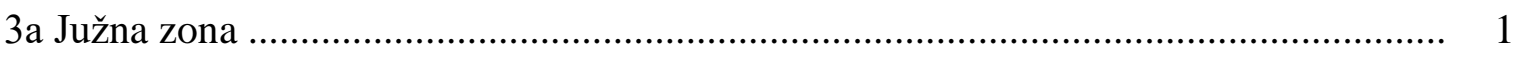

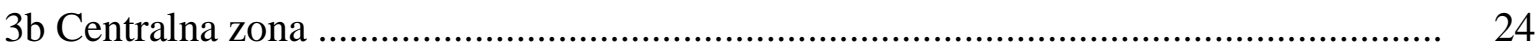

3c Neolit sjeveroistočne Bosne - uticaj starčevačke i vinčanske kulture ..................... 31

IV

\section{Gornja Tuzla}

4a Zbog čega se Gornja Tuzla nije desila u Tuzli?

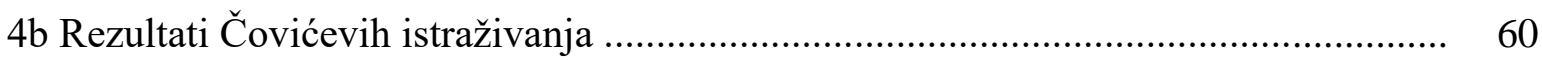

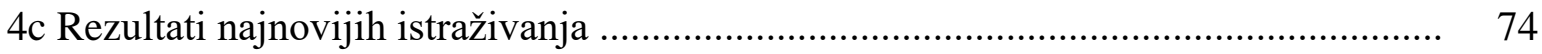

4d Pitanje apsolutne hronologije ....................................................................... 96

$\mathbf{V}$

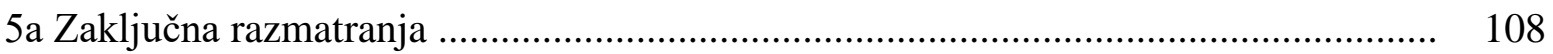

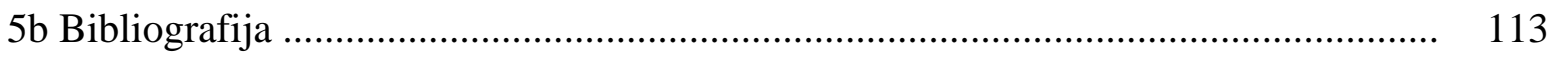

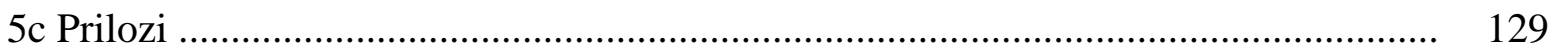

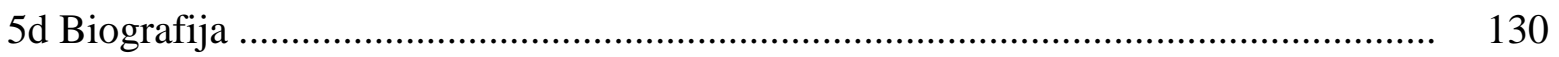

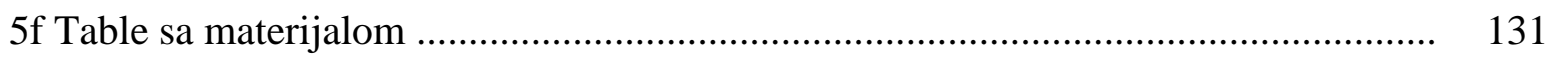




\section{1a Uvod}

Rad je koncipiran u nekoliko tematskih cjelina koje za cilj imaju obradu dosadašnjih saznanja o neolitu Bosne i Hercegovine, odnosno neolitu sjeveroistočne Bosne. S obzirom na nedostatak novijih istraživanja u odnosu na istraživanja tokom jugoslavenskog perioda, prvi dio rada obuhvaća sintezu ranijih zaključaka, koja predstavlja bazu za novija razmišljanja. Kapitalno djelo Praistorija jugoslavenskih zemalja, objavljeno krajem sedamdesetih godina 20. stoljeća, smatra se vrhuncem dotadašnjih istraživanja i rezultata do kojih se došlo. Moderni postratni period obilježen je degradacijom naučnih istraživanja u praktičnom i teorijskom smislu, što se posebno odnosi na prostor sjeveroistočne Bosne. Kada je u pitanju neolit Bosne i Hercegovine, degradacija je također očigledna, što je dovelo do opadanja zainteresiranosti za daleku prošlost ove zemlje. Unutar Bosne i Hercegovine mogu se promatrati tri kulturne zone u kojima su se razvile pojedine kulturne grupe, a to su: zona na sjeveru i sjeveroistoku Bosne i Hercegovine dominantno pod utjecajem starčevačke, a kasnije i vinčanske kulture, centralna zona s razvijenom butmirskom kulturom, te južna zona gdje se razvila lisičićka kultura, usko vezana za jadransko područje.

Istraživanje također obuhvata posmatranje geoloških i geografskih odrednica prostora sjeveroistočne Bosne, kao i klimatskih mehanizama i promjena tokom neogena do početka holocena, kada je područje Tuzle bilo obuhvaćeno Paratetisom (staro more). Kao rezultat toga, razvile su se razne geološke formacije od kojih je najzanimljivija solna formacija. Analizirat će se Tetima, lokalitet bogat rudama soli, koji se nalazi nešto sjevernije od Gornje Tuzle i gdje izvire rječica Jala koja je svojim tokom nanosila halit (kamenu sol) do mjesta gdje se formiralo naselje. Posmatrano sa geografskog aspekta, područje na kojem se nalazi današnje naselje Gornja Tuzla okruženo je brdima, pa neki veći razvoj nije bio moguć, kao što se to dogodilo u Donjoj Tuzli odnosno današnjem gradu Tuzli. Postavlja se logično pitanje: zbog čega se Gornja Tuzla nije dogodila u Tuzli, što je to navelo neolitsko stanovništvo da naseli ovo područje? Riječ Tuzla je osmanskog porijekla - tuz znači sol, pa se već samo na osnovi eponima može zaključiti koji je to elemenat bio presudan pri određivanju najpovoljnijeg mjesta za podizanje prvih naseobina. Prema geološkim saznanjima, na području Gornje Tuzle, kamena sol se nalazila veoma blizu površine, ako ne i na samoj površini (Vrabac, Ferhatbegović, Đulović, Bijedić 2010). Eksploatacija soli zna biti veoma mukotrpan i kompliciran proces, ali u slučaju Gornje Tuzle taj je postupak bio lakši s obzirom na površinske nalaze kamene soli koji su omogućavali jednostavan pristup ovom vrijednom mineralu. Danas na području Tuzle 
postoje dva aktivna rudnika soli, od kojih je jedan u neposrednoj blizini lokaliteta Gornja Tuzla, na području Tetime koja se nalazi sjevernije u odnosu na sam lokalitet. Ležište kamene soli Tetima smješteno je na južnim obroncima Majevice, oko $12 \mathrm{~km}$ sjeveroistočno od Tuzle, svega nekoliko kilometara sjevernije od Gornje Tuzle, i zahvata površinu od oko $106 \mathrm{~m}^{2}$ (Nuhanović 2010).

Hipotezu o vitalnoj važnosti soli za neolitske populacije na Balkanu iznio je N. Tasić i svoju je ideju potvrdio kartiranjem ranoneolitskih nalazišta uporedivši ih s poznatim depozitima soli, kako bi došao do zaključka da je gotovo svako nalazište na neki način povezano sa solju (Tasić 2012). Činjenica je da na područjima bogatim rudama soli dolazi do značajnije mješavine kulturnih elemenata, kao što je to slučaj na lokalitetu Gornja Tuzla gdje se miješaju elementi kultura Starčevo - impresso i Starčevo - Vinča. Gornja Tuzla je rijetko nalazište na Balkanu gdje dolazi do direktne korelacije između dvije velike i značajne kulturne grupacije, starčevačke i vinčanske. Samim time lokalitet Gornja Tuzla predstavlja jedno od značajnijih prahistorijskih nalazišta ne samo u Bosni i Hercegovini, već i u široj regiji gdje sol predstavlja okosnicu života svake kulturne skupine koja se tu nastanila.

$\mathrm{Na}$ sjeveroistoku Bosne i Hercegovine postoji nekoliko lokaliteta nastalih tokom neolita, poput Varoši kod Koraja, naselja Gradina u Grbači, Gradine u općini Orašje, Donje Tuzle, Donje Mahale, Donjeg Klakara, Gradca u selu Batkovići kod Bijeljine, Dobrovca sjeverno od Čelića te najvećeg i ujedno najstarijeg naselja ove zone - Gornje Tuzle (Benac 1958; 1960; Kosorić 1967; 1970). Đuro Basler je 1949. godine prvi konstatovao postojanje lokaliteta, vezano uz nalaz jednog stariježeljeznodobnog groba (Čović 1961). Nedugo zatim Borivoj Čović je otvorio nekoliko sondi sa ciljem da utvrdi ima li više grobova iz željeznog doba. Međutim, prilikom kopanja Čović je, umjesto da pronađe dodatne grobove, shvatio da se kulturni sloj nastavlja u dubinu, što je rezultiralo otvaranjem velike sonde 1958. godine (sonda II-1958) gdje se do zdravice došlo na dubini od 5,50 m. S obzirom na to da nije bilo recentnih oštećenja slojeva, ova sonda uzeta je kao stratigrafska baza. Prema Čovićevoj analizi, najdublji slojevi pripadaju starčevačkoj kulturi na koju se u mlađim periodima nadovezala vinčanska kultura, s najplićim slojem (stratum I) koji Čović svrstava u eneolitski period. Zahvaljujući ovom istraživanju došlo se do prvih rezultata apsolutne hronologije, ali sam Čović je bio veoma rezerviran kada je u pitanju radiokarbonsko datiranje i dobivene je rezultate smatrao pogrešnima, pa ovom problemu nije posvetio veću pažnju. Kako je i sam naveo, apsolutna hronologija naselja Gornja Tuzla u potpunosti je ovisna o određenju apsolutne hronologije onih kultura za koje se određeni stratum veže, pa je, pri tadašnjem nedostatku podataka kojima mi danas jednim dijelom raspolažemo, ostavio ovo pitanje nedorečenim. 
Nakon Čovićevog iskopavanja i objavljenih rezultata uslijedio je dugi niz godina u kojima se na ovome lokalitetu ništa nije dešavalo. Tek 2007 - 2009. godine realizira se projekt pod pokroviteljstvom JU Muzej Istočne Bosne Tuzla, koji je predvodila Zilka Kujundžić-Vejzagić, arheologinja i muzejska savjetnica Zemaljskog muzeja Bosne i Hercegovine u Sarajevu, u saradnji sa austrijskim Institutom za arheologiju koji su zastupali Andreas Lippert i Georg Tiefengraber. Rezultati iskopavanja nikada nisu objavljeni, osim u jednom kratkom članku, napisanom 2009. a objavljenom 2017. godine, koji se osvrće na radiokarbonsku analizu (Kujundžić-Vejzagić, Lippert, Tiefengraber, Bakalović 2017). Ipak, zahvaljujući terenskoj dokumentaciji i materijalnim nalazima iz muzejskog depoa, koji se nalaze u Muzeju Istočne Bosne u Tuzli, omogućeni su pristup materijalu i njegova obrada. Analiza materijala iskopanog tokom ove kampanje imat će pri pisanju ovoga doktorskog rada značajnu ulogu, uz komparaciju s ranijim Čovićevim istraživanjem, ali i s najnovijim iskopavanjem provedenim u augustu 2018. godine. 


\section{1b Geografske odrednice sjeveroistočne Bosne}

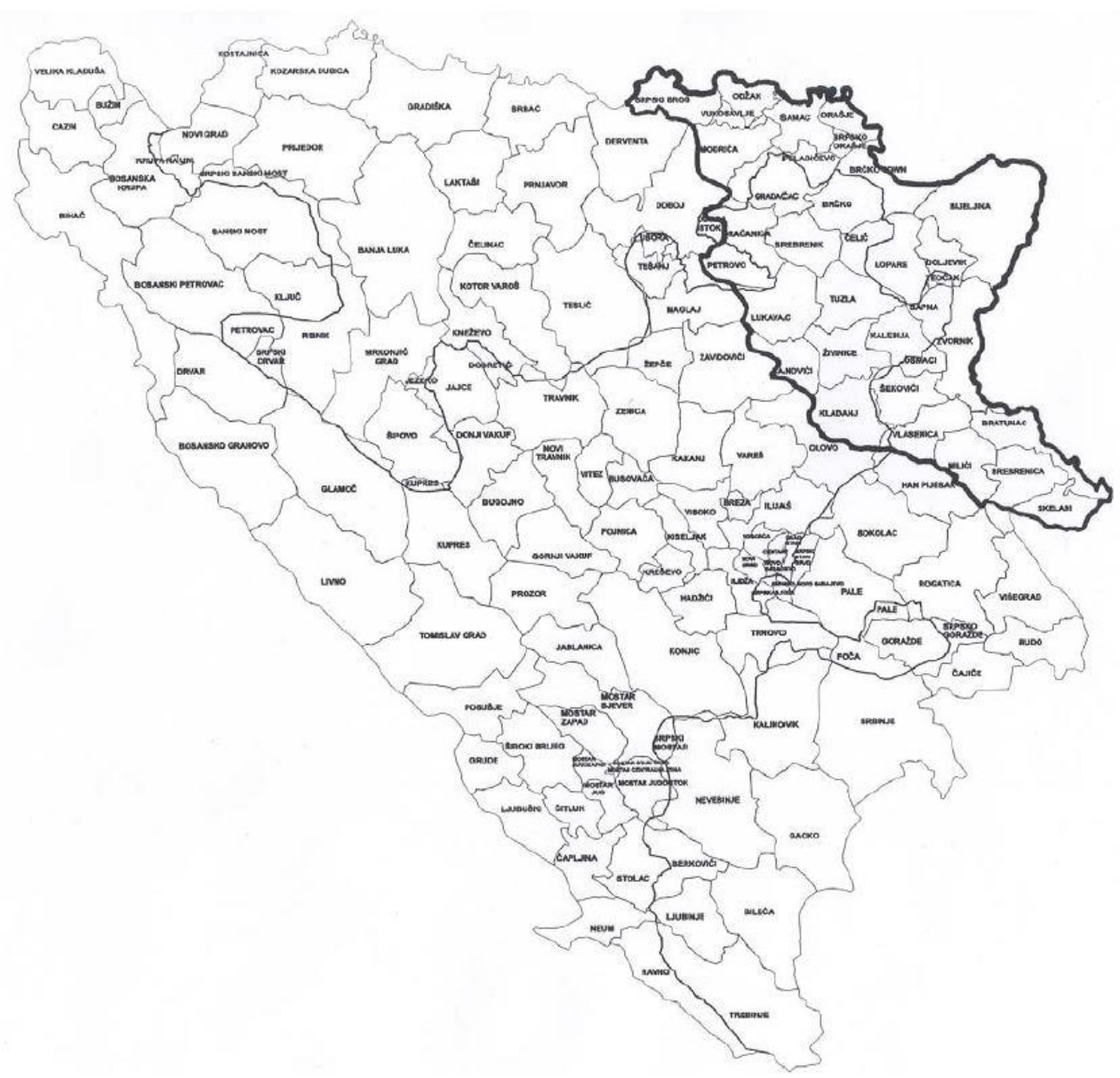

Slika 1. Karta BiH sa označenim administrativnim područjem sjeveroistočne Bosne (www.fzzpr.gov.ba/download/doc/prilog_2_socioekonomska_analiza_regije_sjeveroistocna_bosna.pdf/f07843f2b259b4e 221c6f3a467b7d64e.pdf sjeveroistocna bosna)

U geomorfološkom smislu, prostor Bosne i Hercegovine nije jedinstvena cjelina s obzirom na to da se nalazi između istočne jadranske obale i centralnog Balkana, gdje izuzetno ravničarsko područje na sjeveru u središnjem dijelu prelazi u brdske predjele pa do planinskih vrhova od oko 1000 - $1500 \mathrm{~m}$. Geografski posmatrano, sjeveroistočna Bosna pripada zapadnom dijelu jugoistočne Evrope, Balkanskom poluostrvu, južnom dijelu Panonske nizije i sjevernom dijelu dinarskog planinskog sistema. Reljefnu strukturu Bosne i Hercegovine čine: planinski masivi i hrptovi sa predgorskim stepenicima, površi, gorska uzvišenja i pobrđa, kraška polja, doline, zavale i kotline (Lepirica 2012: 5). Centralni dio Bosne i Hercegovine je područje između primorskog i panonskog prostora, okruženo planinama Igmanom, Trebevićem i Jahorinom na jugu i jugoistoku, Romanijom na istoku, 
Ozrenom i Ravni na sjeveroistoku te Vlašićem i Manjačom na zapadu. Bogat zelenilom i vodama te plodnim zemljištem, ovaj prostor bio je idealan za neolitske populacije. Hercegovački predio, južno od Bjelašnice, karakteriše krševiti predio koji se spušta prema Jadranskom moru.

Sjeveroistočni dio Bosne i Hercegovine, na koji se ovaj rad fokusira, može se podijeliti na dvije cjeline kojima međusobnu prirodnu granicu čini planina Majevica. Na sjevernoj strani nalazi se Bosanska Posavina, dok je na južnoj brdoviti predio koji se nadovezuje na centralnu Bosnu. ${ }^{1}$ Istočnu i sjevernu granicu čine rijeke Drina i Sava, a od juga prema zapadu granica se proteže istočnim obroncima planina Javora, Konjuha i Ozrena, zatim dolinom donjeg toka rijeke Spreče i zapadnim padinama planine Trebovca, te dolinom rijeke Tolise do Save na sjeveru. Regija ima oblik nepravilnog trougla, a izdužena je u pravcu sjeverozapad - jugoistok sa površinom od $6.813 \mathrm{~km}^{2}$, što čini 13,3\% državne teritorije (Kudumović-Dostović 2017: 18). U prirodno-geografskom pogledu, prostor sjeveroistočne Bosne predstavlja izuzetno povoljno područje za naseljavanje s obzirom na geomorfološke, klimatske, pedološke i hidrografske uvjete. U tom se smislu najviše ističu plodno zemljište te mineralna i rudna bogatstva (Omerčević, Šaković: 37). Sjeveroistočna Bosna je, dakle, područje bogato podzemnim vodama, potocima, jezerima te termalnim i mineralnim izvorima. Pored stočarstva i zemljoradnje kao glavnih poljoprivrednih grana, karakterišu je i rudno-mineralna bogatstva među kojima se posebno ističu rezerve soli, boksita, olova, cinka, kaolina, mramora, kvarca itd. Klima je umjereno kontinentalna i jasno se očituju ljeta i zime, kao i prelazni periodi u proljeće i jesen. S obzirom na fizičke specifikume sjeveroistočne Bosne, u kojoj razlika između najniže (Posavina $80 \mathrm{~m}$ ) i najviše (Konjuh $1.327 \mathrm{~m}$ ) tačke iznosi čak $1.247 \mathrm{~m}$, posmatrajući od nizijskog sjevera ka planinskom jugu smjenjuje se nekoliko klimatskih varijanti modifikovanih nadmorskom visinom. ${ }^{2}$ Veliku ulogu pri modifikaciji klime ima zapadni vjetar kao najznačajniji pored lokalnih vjetrova, koji uslijed temperaturnih razlika znatno utiče na isparavanje vode i doprinosi klimatskim promjenama. Navedene klimatske prilike znatno utiču na strukturu zemljištā sjeveroistočne Bosne, koja se mogu podijeliti u dvije vrste, automorfna zemljišta koja vlagu dobivaju od atmosferskih padavina te hidromorfna koja, pored padavina, vlagu dobivaju pod uticajem podzemnih voda. Sjeverni dio prostora karakterišu hidromorfna, a južni automorfna zemljišta.

\footnotetext{
${ }^{1}$ Sastavni dijelovi sjeveroistočne regije su: Bosanska Posavina, Semberija, dolina Spreče i Tuzlanska kotlina, Trebava, Majevica, zvorničko Podrinje, Ludmer, Osat i Birač. Zahvaljujući tim fizičko-geografskim specifičnostima, regija se često naziva Posavsko-sprečko-majevičko-donjodrinska regija.

${ }^{2}$ Vazdušne mase koje se formiraju iznad Arktika i Sibira obrazuju anticiklon nad istočnom i centralnom Evropom, koji na prostor sjeveroistočne Bosne prodire kao studeni arktički zrak kada nastupa hladniji period godine.Nasuprot tome, tokom toplijeg dijela godine najveći uticaj imaju zračne mase sjevernog dijela subtropskog pojasa koje donose suhi i topli zrak iz Sahare. Ove zračne mase se prelaskom preko Sredozemnog i Jadranskog mora navlaže, dok se nad visokim bosanskohercegovačkim planinskim vrhovima rashlade, uzrokujući najveće padavine. Prelazeći preko planinskog pojasa Dinarida, do sjeveroistočne Bosne dopiru kao tople i suhe mase i uzrokuju ljetni sušni period (Kudumović-Dostović 2017: 31).
} 
Tokom neolita, na prostoru sjeveroistočne Bosne razvilo se više naselja od kojih neka postoje i danas, što svjedoči o značajnom kontinuitetu života na ovom prostoru. Riječ je o naseljima: Gradina u Grbači (opština Bosanski Šamac), Gradina u opštini Orašje, Donja Tuzla, Donja Mahala, Donji Klakar, Korića Han kod Gračanice, Simin Han kod Tuzle, Gradac u selu Batkovići kod Bijeljine, Dobrovac sjeverno od Čelića, Varoš kod Koraja, Gornja Tuzla itd. Lokalitet Korića Han najistraženije je naselje u dolini rijeke Spreče, odnosno u području odakle Spreča izvire kod Zvornika do mjesta gdje se ulijeva u rijeku Bosnu kod Doboja (Kosorić 1980: 103). Lokalitet Varoš kod Koraja ima oblik većeg uzvišenja (tela) koje se prema jugu spušta u ravnicu, kao što je to slučaj i u Gornjoj Tuzli. Smješten je u istočnom kraju Luke, doline koja se pruža ispod sela Koraja (Benac 1960: 46). Gornja Tuzla, najstarije te ujedno najveće i najznačajnije naselje sjeveroistočne Bosne o kojem će biti najviše govora u ovome radu, smještena je na krajnjim obroncima planine Majevice, uz gornji tok riječice Jale, udaljena desetak kilometara sjeveroistočno od Tuzle.

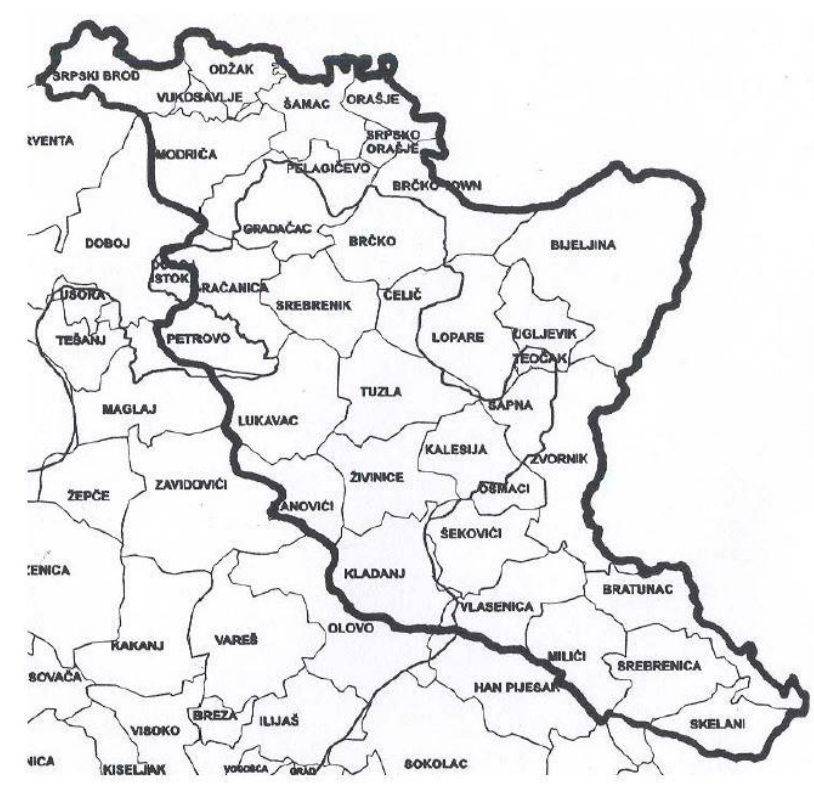

Slika 2. Granice sjeveroistočne Bosne (www.fzzpr.gov.ba/download/doc/prilog_2_socioekonomska_analiza_regije_sjeveroistocna_bosna.pdf/f07843f2b259b4e 221c6f3a467b7d64e.pdf sjeveroistocna bosna) 


\section{II}

\section{2a Povijest istraživanja neolitskih lokaliteta Bosne i Hercegovine}

Kapitalno djelo Praistorija jugoslavenskih zemalja (PJZ), koje su krajem sedamdesetih godina 20. stoljeća objavili tada najveći stručnjaci u arheologiji na prostoru zemalja bivše Jugoslavije, može se nazvati određenim vrhuncem dotadašnjih arheoloških istraživanja, jer sadrži neke od najvažnijih rezultata i zaključaka do kojih se do tog vremena došlo. Ukoliko se osamdesete godine 20. stoljeća smatraju vrhuncem u istraživanju prahistorije spomenutog prostora, onda period nakon toga treba predstavlja jedan vid degradacije naučnih istraživanja, barem što se tiče kvantiteta poduzetih radova na terenu. Kada je u pitanju neolit Bosne i Hercegovine, ta degradacija je očigledna, što je dovelo do opadanja zainteresovanosti za daleku prošlost te zemlje. Prošlost Bosne i Hercegovine nužno je uticala na razvoj arheologije, odnosno prahistorijske arheologije, pa se taj proces može podijeliti na nekoliko faza. Posmatrano iz hronološkog apsekta, krajem 19. stoljeća Bosna i Hercegovina postaje dio Austro-Ugarske Monarhije koja 1888. osniva Zemaljski muzej u Sarajevu (Dautbegović 1988: 3). Već naredne godine počinje da izlazi Glasnik Zemaljskog muzeja u kojem su se objavljivali rezultati do kojih se dolazilo na raznim iskopavanjima. Godine 1914. Bosna i Hercegovina, kao zemlja u sastavu Austro-Ugarske Monarhije, uzima učešće u Prvom svjetskom ratu da bi nakon toga postala dio Kraljevine Jugoslavije. Tada stupa druga faza arheoloških istraživanja koja traje sve do početka Drugog svjetskog rata (godine 1939.). Nakon kapitulacije Njemačke (godine 1945.) Bosna i Hercegovina postaje dio bivše Jugoslavije, što označava treću i ujedno najvažniju fazu istraživanja i razvoja prahistorijske arheologije Bosne i Hercegovine, kao i istraživanje kultura koje su živjele na ovom prostoru. Postratni period obilježen je stagnirajućom fazom u istraživanju prahistorije Bosne i Hercegovine, posebno u što se tiče terenskog rada jer je trebalo dosta vremena da se arheološka iskopavanja ponovo počnu izvoditi. Ipak, u ovoj fazi donešeni su neki od najvažnijih zaključaka s obzirom na razvoj tehnologije koja igra ključnu ulogu u procesu terenskog istraživanja, ali i u procesu analize podataka koji veoma često otkrivaju nove činjenice.

Bosna i Hercegovina se nalazi na centralnom dijelu Balkana i predstavljala je određenu zonu u kojoj je dolazilo do ispreplitanja raznih uticaja koji su dolazili iz okolnih regija, u nauci prihvaćenih pod nazivima: centralnobalkanska regija, jadranska, prelazna i sjeverna regija. ${ }^{3}$ Kulture koje su se razvile na prostoru Bosne i Hercegovine spadaju u tzv. prelaznu zonu, omeđenu panonskom regijom na

\footnotetext{
${ }^{3}$ Tvorac termina "prelazna zona" jeste Alojz Benac (Benac 1979: 24).
} 
sjeveru i jadranskom na jugu. Glavnina teritorija prelazne regije pruža se od sjeverozapada prema jugoistoku, paralelno sa jadranskom obalom, dijeleći se na taj način na tri dijela: oblast oko gornjeg toga rijeke Bosne (oblast centralne Bosne), južnu Metohiju i Ohridsko jezero - južnu Pelagoniju (Benac 1979: 363). Unutar Bosne i Hercegovine mogu se također posmatrati tri kulturne zone, unutar kojih su se razvile pojedine kulturne grupe, a to su: zona na sjeveru i sjeveroistoku Bosne i Hercegovine dominantno pod uticajem starčevačke, a kasnije i vinčanske kulture, centralna zona sa razvijenom butmirskom kulturom, te južna zona gdje se razvila lisičićka kultura, usko vezana za jadransku oblast.

Godine 1893. otkriveno je naselje u Butmiru, što će se kasnije ispostaviti najvažnijim otkrićem ne samo prve faze iskopavanja, nego i jedan od najznačajnijih neolitskih lokaliteta Bosne i Hercegovine. ${ }^{4}$ Veoma brzo Butmir i butmirska kultura postali su pojam neolitskog doba u ovom dijelu Balkana, a ono što je možda najvažnije i što je izazvalo mnoge rasprave u naučnim djelima jeste njena kulturna izoliranost u odnosu na druge neolitske grupe (Benac 1979: 368). U ranim godinama prve faze vršena su razna istraživanja pod vodstvom uglavnom Fiale i Radimskog, te je otkriveno još nekoliko manje značajnijih lokaliteta i pojedinačnih nalaza. Među njima valja istaći Naklo kod Vojkovića (Fiala 1892: 211), istraživanja pećina u Bosni naseljenih neolitskim populacijama, te posebno Marinovu pećinu oko $19 \mathrm{~km}$ od Sarajeva gdje je pronađen materijal od ilovače, bez ukrasa i slabo pečen. ${ }^{5}$ Nešto kasnije pronađeno je još nekoliko lokaliteta: Kraljevine kod Novog Šehera gdje su od 1906. do 1908. godine vršena iskopavanja, ${ }^{6}$ neolitsko naselje u Donjem Klakaru kod Bosanskog Broda i naselje Novi Šeher, inače poznato kao radionica poliranog kamenog oružja. Kao i mnoga druga neolitska naselja, i Donji Klakar je lociran na nešto uzvišenijem tlu u blizini rijeka, jezera, močvara i sl. Prema pronađenoj keramici, naselje u Klakaru se razlikuje od butmirskog, keramički ostaci su primitivni i nesavršeni i sa slabom ornamentikom, a oblici zastupljeni u najjednostavnijoj formi (Truhelka 1906: 449). Kada je riječ o iskopavanjima za vrijeme prve faze, potrebno je još istaknuti i otkriće nekoliko prahistorijskih utvrda oko Sarajeva koje su nastale u mlađem neolitu a svoj vrhunac doživjele u nešto kasnijim vremenima. Riječ je o kompleksu Soukbunar, Debelo Brdo i Zlatište, koji je prvi otkrio Fiala, a poseban rad o tome ostavio Vejsil Čurčić (Čurčić 1908: 363).

\footnotetext{
${ }^{4}$ Do otkrića je došlo prilikom kopanja temelja Poljoprivredne škole, nakon čega su uslijedila sistematska istraživanja prilikom kojih je otkriveno 89 zemunica te tragovi kućnih ognjišta. Tadašnja Zemaljska vlada je 1894. godine u Sarajevu organizovala naučni skup evropskih arheologa, pa je butmirska kultura od tada pa do danas predmet interesovanja stručnjaka iz cijelog svijeta.

${ }^{5}$ Uglavnom je riječ o nepropečenoj keramici (Fiala 1892: 237).

${ }^{6} \mathrm{Na}$ osnovu keramičkih nalaza pretpostavlja se da je ovo naselje nastalo u srednjem neolitu i da mu je život produžen u mlađem neolitu, jer keramički ostaci asociraju na butmirsku kulturu u nešto uproštenom obliku. Rezultati ovih istraživanja nisu nikada u cjelini objavljeni (Benac 1979: 369).
} 
Drugu fazu istraživanja između dva svjetska rata obilježili su mnogi unutrašnji problemi sa kojima se susretala Bosna i Hercegovina, a ni sama istraživanja nisu donijela neke značajnije rezultate. Najvažniji lokalitet otkriven u drugoj fazi je naselje u Kaknju, pa će se prema istoimenom nalazištu u nauci razviti termin kakanjska kultura, ${ }^{7}$ za koju se smatralo da obuhvata srednjeneolitska naselja centralne Bosne. Do otkrića je došlo prilikom izgradnje pruge 1933. godine, kod ušća Zgošćanskog potoka u rijeku Bosnu (Benac 1979: 369). Pod vodstvom Mihovila Mandića iskopani su ostaci keramičkih, kamenih i koštanih nalaza, ali prilikom tadašnjih iskopavanja nisu donešeni neki značajniji zaključci o samom karakteru ove kulture. Mandić je poduzeo još nekoliko istraživanja u okolini Travnika (Mandić 1926: 35), kao i dosta značajnije iskopavanje neolitskog naselja u Donjoj Mahali kod Orašja na Savi. Konstatovao je da se ovo naselje nalazilo između naselja u Donjoj Dolini i onoga Donjem Klakaru za kojeg tvrdi da je postojalo u isto vrijeme kada i naselje u Donjoj Mahali, te da su u pitanju dva naselja koja se hronološki mogu datirati među najstarija neolitska naselja Bosne i Hercegovine (Mandić 1927: 199), što se kasnije ispostavilo netačnom konstatacijom. Potrebno je još i ukazati i na otkriće Hrustovačke pećine, o kojoj su pisali Mandić i geolog Ahmed Polić, pred sam kraj druge faze arheoloških istraživanja u Bosni i Hercegovini. ${ }^{8}$

\footnotetext{
7 Kasnije će se ispostaviti da je kakanjska kultura, preimenovana u početnu fazu butmirske kulture- Protobutmir Ia (Perić 1995: 79).

8 Zanimljiv je jedan slučaj prilikom rekognisciranja ovog lokaliteta. Naime, stanovnici Hrustva su se bunili protiv iskopavanja ove pećine i napali su Antu Krčana koji je namjeravao da istražuje, ali je bio primoran da se povuče sa lokaliteta. Kasnije je Sergejevski preko Zemaljskog muzeja tražio zaštitu od upravne vlasti, kako bi se istraživanja nastavila (Mandić 1939: 65; Polić 1939: 1 -7).
} 
Treća faza predstavlja vremenski period od kraja Drugog svjetskog rata do objave PJZ 1979. godine, u kojoj su objedinjeni svi zaključci do kojih se došlo u toku sve tri faze. PJZ je, kao što je već rečeno, kapitalno djelo arheološke nauke, sadržano u pet tomova od kojih je drugi tom posvećen neolitskom periodu. U trećoj fazi je došlo do izdvajanja centralne Bosne u prelaznu fazu, zahvaljujući intenziviranijim istraživanjima i rezultatima koje su ta istraživanja dala. Neposredno nakon rata, 1948. godine započela su istraživanja lokaliteta Nebo u dolini Bile kod Travnika, o čemu je pisao Alojz Benac (Benac 1949/50: 5). Pored otkrića raznih stambenih objekata, Benac je na osnovu pronađene keramike došao do značajnog zaključka. Uvidjevši da je sličnost sa Butmirom jako velika, zaključio je da Butmir nije nikakva usamljena pojava, već da pripada široj neolitskoj grupi (Benac 1953: 263) kojoj je pripadao i lokalitet Nebo, nazvanoj butmirska kultura iz prostog razloga što je Butmir otrkiven znatno ranije. Uporedo sa iskopavanjima u Nebu vršena su terenska istraživanja u naselju Mujevine, na samoj obali rijeke Bile. ${ }^{9}$

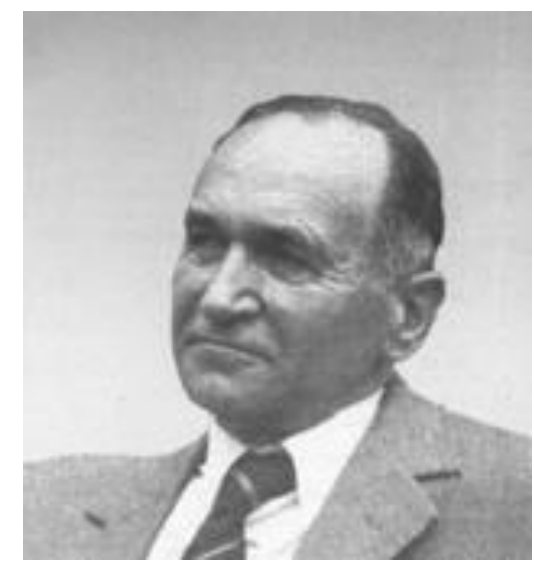

Unatoč nedovoljnim elementima za potpunije istraživanje, Benac je isprva pretpostavio da Mujevine pripadaju kakanjskoj kulturi (Benac 1949-50: 25), ali kasnije je uočio da takav zaključak nema materijalne osnove s obzirom na to da su trake sa ubodima osnovni ornamentalni motiv u Mujevinama (Benac 1956: 174), što se razlikuje od situacije u naselju u Kaknju. Sve do objave $P J Z$ ostalo je nesigurno pitanje kulturne stratigrafije Mujevina, ali se pretpostavljalo da je riječ o kulturi mlađeg neolita koja pripada butmirskom kompleksu (Benac 1979: 371).

Slika 3. Dr. Alojz Benac (https://bs.wikipedia.org/wiki/Alojz_Benac)

U maju 1952. godine vršeno je prvo iskopavanje u Lisičićima (kasnije će se ispostaviti - vrlo značajnom naselju), udaljenom stotinjak metara od rijeke Neretve (Benac 1954: 137). Sistemsko iskopavanje je uslijedilo naredne godine kada su ustanovljena dva stratuma, donji (stratum A) i gornji (stratum B). Komparirajući materijal iz Lisičića sa Butmirom, uočava se da u kamenom oruđu i nema neke značajne razlike, dok keramika sugeriše da je riječ o različitim stilovima.

Naime, butmirska keramika ne upotrebljava ornamente girlanda i šrafiranih polukrugova koji su zapravo najčešći ornamentalni motivi u Lisičićima (Benac 1955: 67). Također, u Lisičićima nema tipičnog trakastog motiva - trake sa ispunjenim tačkicama, što predstavlja osnovu u ornamentici

\footnotetext{
${ }^{9}$ Problem je nastao kada se shvatilo da je veliki dio naselja oštećen zbog izlijevanja vode u naselje, pa je bilo jako teško doći do konkretnijeg zaključka.
} 
Butmira (Benac 1955: 67), kao ni spiralne ornamentike koja je jedna od glavnih osobina butmirske kulture (Benac 1971: 136). Neke od osnovnih osobina keramike u Lisičićima su nedostatak slikane keramike i posuđa na četiri noge, kao i monohromne keramike sa čvrstom bojom. Zatim, osnovne ukrase predstavljaju motivi polukrugova i girlandi, ukras nema strogo geometrijske osobine, preovladavaju motivi izvedeni urezivanjem i udubljivanjem, brazdasti ukras se u potpunosti povezuje sa vinčanskom kulturom i preuzet je preko butmirske kulture (Batović 1979: 600). Keramika iz Lisičića se znatno razlikuje od starije danilske i samim time se nameće zaključak da ona nije izravno naslijedila tu kutluru, ali je u dosta bliskim vezama sa hvarskom kulturnom grupom, što je rezultiralo postankom hvarsko-lisičićke kulture. ${ }^{10}$ Poznat je još jedan lokalitet koji je pripadao jadranskom kompleksu, a nalazio se na samoj periferiji. To je Popov Do na Hranjenskom potoku koji se kod Goražda ulijeva u Drinu. Keramička roba, na kojoj se primjećuju motivi dvostruke girlande i tehnika udubljivanja, bliska je sa onom iz Lisičića. Ujedno, pošto je riječ o perifernom naselju na rijeci Drini, nameće se zaključak da na tom prostoru valja tražiti granicu između vinčanskog i jadranskog kompleksa (Benac 1959: 61).

Početkom pedesetih godina 20. stoljeća, prilikom rekognisciranja terena koje su izvršili članovi Zemaljskog muzeja, u Arnautovićima kod Visokog otkriven je još jedan lokalitet. Tokom naredne decenije vršeno je nekoliko sondažnih iskopavanja i na osnovu pronađenog materijala utvrdilo se da je riječ o naselju za koje se smatralo da pripada kakanjskoj (protobutmirskoj) kulturi srednjeg neolita Bosne i Hercegovine. ${ }^{11}$ Kasnija istraživanja su pokazala da je naselje u Arnautovićima mlađe od onoga u Kaknju. Paralelno u isto vrijeme nastavila su se istraživanja u Kaknju, koja su dala osnove za kulturno i hronološko datiranje ovog naselja. U najstarijim slojevima uočljiva je primitivnost $u$ obradi keramičke robe, kao i rijetkost glačanog oruđa, što asocira na starije periode. Time se utvrdilo da su Kakanj i Butmir hronološki različite kulturne grupe i da je Kakanj stariji od Butmira (Benac 1956: 167), što hronološki podržava tezu da kakanjska kultura ustvari predstavlja početnu fazu butmirske, odnosno Protobutmir Ia. Među osnovnim karakteristikama kakanjske keramike su obilje vaza sa cilindričnim i zvonolikim nogama, kao i obilje šolja i ritona na četiri noge, dok se ornamentika uglavnom sastoji od urezanih linearnih motiva. Benac je stoga smatrao da je kakanjska kultura, kao i naselje u Mujevinama, kulturno i hronološki povezano sa mlađom linearnom keramikom Podunavlja (Benac 1963: 25). Krajem šezdesetih godina, na mjestu Raskršće na obali rijeke Trstionice koja se ulijeva u Bosnu otkriven je izuzetno značajan lokalitet koji je dobio naziv

\footnotetext{
${ }^{10}$ Prema Benčevom mišljenju, hvarska kultura se dodiruje sa danilskom samo po nekoliko elemenata, jer je hvarska naslijedila danilsku kulturu, ali nije proizašla iz nje (Batović 1979: 618).

11 Keramički oblici su identični, ukrašavanje gotovo isto kao i u Kaknju. Karakteristika Arnautovića jesu grube posude na niskoj cilindričnoj nozi i uglasti motivi (Benac 1965: 261).
} 
Obre I. Naselje Obre I starije je od Kaknja, prva dva kulturna stratuma pripadaju starčevačkoimpresso kulturnoj grupi iz vremena srednjeg neolita, dok treći stratum predstavlja rane početke kakanjske kulture (današnji Protobutmir Ia). Četvrti kulturni stratum naselja Obre I prema Benčevim
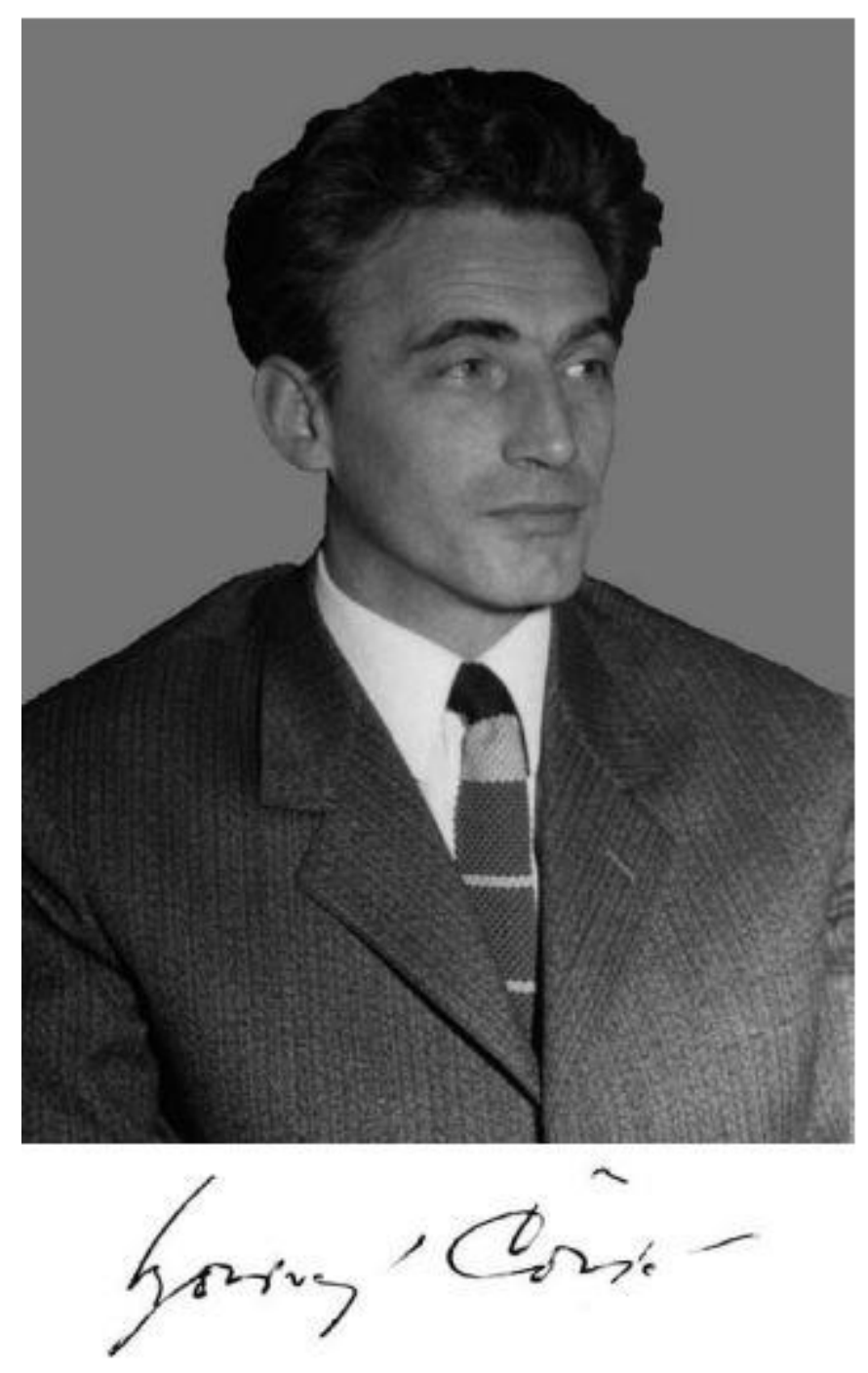

zaključcima pripada klasičnoj kakanjskoj kulturi, odnosno butmirskoj (Benac 197273: 60).

Za prve dvije faze naselja Obre I potrebno je naglasiti da pripadaju periodu srednjeg, a ne starijeg neolita kako je Benac navodio (Benac 1972-73: 62) i nazvao je starčevačko-impresso kulturom (Brukner 1976: 45), koja ujedno predstavlja najstariju kulturnu grupu centralne Bosne. Na ovom primjeru se najbolje vidi ispreplitanje uticaja sa istoka i zapada, odnosno između starčevačke i jadranske komponente, što je dovelo do formiranja posebnog tipa keramičkog materijala.

Slika 4. Borivoj Čović (Godišnjak ANUBiH 34, 2005)

Naime, tehnološki proces stvaranja keramike u naselju Obre I drugačiji je i od onog u Starčevu i od onog na Jadranu, odakle proizilazi ideja stvaranja posebne, lokalne

varijante ovih kultura koje su postale stvaraoci starčevačko-impresso komponente (Brukner 1976: 63). U obje starije faze naselja Obre I dominira barbotin keramika starčevačkog tipa naspram monohromne keramike sa Jadrana, što je dovelo do determinisanja barbotin keramike kao "domaćinske" asocirajući na taj način da je starčevačka komponenta činila snažniju bazu prilikom formiranja naselja. ${ }^{12}$ Slojevi starčevačke kulture u Bosni i Hercegovini nisu poznati samo u naselju Obre I, već i u najdubljim slojevima naselja u Gornjoj Tuzli otkrivenom 1949. godine. Nakon što je Borivoj Čović uspostavio stratigrafiju Gornje Tuzle, pojavile su se nove ideje oko smjene

\footnotetext{
12 Elemente starčevačke kulture predstavljaju barbotin keramika, žrtvenici, gruba keramika sa urezanim ornamentima, fina slikana keramika, kao i tipični plastični proizvodi, dok s druge strane elemente impresso kulture predstavljaju fina keramika sa tremolo ukrasima, monohromna keramika te impresso ukrasi urezani noktom (Benac 1972-73: 60).
} 
starčevačke kulture u korist tada nove vinčanske kulture, koja je gotovo u cijelosti u kulturnom smislu produžila život starčevačkih naselja. Tako se u stratumu VIb i VIa naselja u Gornjoj Tuzli primjećuju brojni ostaci grube barbotin i slikane keramike, ali se ne primjećuje nikakva čvršća granica između ta dva kulturna stratuma (Čović 1960: 87). Ipak, već u narednom stratumu V primjećuje se novi kulturni sloj, ali bez naznaka prekida života. Naime, riječ je o vinčanskom kulturnom sloju koji će se protezati kroz veći dio kulturnih faza ne samo lokaliteta Gornja Tuzla, nego i mnogih drugih naselja u sjeveroistočnoj Bosni. Barbotin keramika gotovo u potpunosti izlazi iz upotrebe, dok slikana keramika više ne postoji (Čović 1960-61: 88). Dakle, sa stratumom V naselja u Gornjoj Tuzli prate se veze sa starijim slojevima Vinče (crna i siva glačana keramika sa kanelurama), dok već stratum II pripada završnoj fazi vinčanske kulture, nakon čega su ovaj lokalitet naselile eneolitske kulture (Čović 1960-61: 121). Manje-više je usvojena hipoteza o formiranju vinčanske kulture i njenom širenju kao rezultat migracije brojnog populacijskog kompleksa iz Male Azije, pa bi se na osnovu toga, kao i na osnovu crnoglačane keramike koju su donijeli sa sobom, moglo pretpostaviti da su tim stanovnicima morali biti poznati bakreni objekti, a možda i osnovni metalurški procesi dobivanja bakra (Čović 1960-61: 127). Sve to ukazuje na kulturne promjene koje su se dešavale na ovim prostorima, kada je vinčanska kulturna grupa potisnula ka sjeveru nosioce slikane keramike, odnosno nosioce starčevačke kulturne grupe. ${ }^{13}$ Posmatrano iz hronološkog aspekta, u stratumu III Gornje Tuzle, paralelnom sa početkom mlađe vinčanske faze, pronađeni su najstariji ostaci bakrenih objekata (Čović 1959: 10).

Pored naselja u Gornjoj Tuzli, koje je svakako jedno od najznačajnijih otkrivenih neolitskih lokaliteta Bosne i Hercegovine, pronađeno je još nekoliko naselja koje je važno istaknuti, a koja uglavnom pripadaju vinčanskoj kulturi. Prije svega, 1956. godine otkriveno je naselje u Varoši kod Koraja, gdje su ustanovljena četiri kulturna stratuma od kojih je IV, najstariji, paralelan sa stratumom V Gornje Tuzle, iz razloga što u ovom naselju nisu pronađeni ostaci slikane keramike. Početak života Varoši vjerovatno je vezan za kraj stratuma VI u Gornjoj Tuzli (Benac 1960: 46), što Benac hronološki veže za stariji dio vinčanske kulture, vinčansko-tordošku fazu (Benac 1958: 8). Godine 1955. otkriveno je neolitsko naselje Gradina u Grbači (opština Bosanski Šamac) koje je mlađe od Varoši, tačnije pretpostavlja se da je ono paralelno sa stratumom II naselja Varoš kod Koraja. Važno je napomenuti i naselje Gradinu u opštini Orašje koje je starije od Grbače, kao i lokalitet Donju Tuzlu otkriven 1955. godine u Rudarskoj ulici. Pretpostavlja se da je riječ o sojeničkom naselju čiji se početak vjerovatno veže za Varoš III odnosno Gornju Tuzlu IV. Važno je istaknuti i naselje Donju

\footnotetext{
13 Prodiranje predstavnika crnoglačane keramike, kao i uticaj jadranske obale u okviru danilske grupe obilježavaju početak mlađeg odnosno srednjeg neolita u Bosni (Brukner 1974: 46).
} 
Mahalu, čiji gornji sloj pripada kostolačkoj kulturi a donji mlađem neolitu odnosno vinčanskoj kulturi, te Donji Klakar koji je imao sličnu strukturu (Benac 1960: 39). Jula 1966. godine otkriveno je naselje Gradac u selu Batković, koje predstavlja periferno naselje vinčanske kulture i vjerovatno pripada periodu kasnog neolita (Kosorić 1967: 21), a zatim i neolitsko naselje na lokalitetu Dobrovac sjeverno od Čelića, čiji osnovni elementi ukazuju na vinčanske (Kosorić 1970: 9). Cijeli je kompleks sjeveroistočne Bosne bio, dakle, pod uticajem vinčanske kulturne grupe, što bi značilo da neolit sjeveroistočne Bosne pripada balkansko-anadolskom kompleksu, za razliku od onoga u centralnom dijelu koji je sačinjen od raznih kulturnih elemenata.

Jadranski uticaji sa juga i zapada djelovali su na razvoj neolitskih naselja Hercegovine, dok su starčevačka i vinčanska kultura uticale na razvoj naselja sjeverne i istočne Bosne. Iz toga proizilazi ideja o prostoru centralne Bosne kao o zoni gdje je dolazilo do ispreplitanja raznih uticaja, što je najbolje pokazalo starije naselje Obre I. Ipak, ovaj prostor je imao svoje karakteristike koje se prepoznaju kod butmirske kulture, koja je zbog svoje zanimljive geneze privlačila veliki broj stručnjaka još u najranijim periodima. Pored naselja u Butmiru, jedan od najznačajnijih predstavnika butmirske kulture jeste svakako naselje Obre II, ${ }^{14}$ koje predstavlja kontinuitet razvoja od srednjeg neolita, preko Protobutmira čiji elementi pripadaju samo prvoj fazi naselja Obre II, do mlađeg neolita i nastanka butmirske kulture. Druga faza naselja Obre II predstavlja početke butmirske kulture, dok u Butmiru u potpunosti nedostaju svi osnovni elementi starije faze ove kulture. ${ }^{15}$ Prema tome, naselje Obre II je najstarije dosad poznato naselje butmirske kulture. Primjećuje se specifikum butmirske kulture koja je nastala kao posljedica kulturnih ispreplitanja raznih uticaja, pa i rasnih, kako to najbolje pokazuje plastična umjetnost. ${ }^{16}$ Ona je i razvila svoj poseban stil, keramiku i poseban ornamentalni sistem koji će se najbolje demonstrirati u samom butmirskom naselju, ali i u naselju Obre II. Tek kasnije će istraživanja u Okolištu kod Visokog, lokalitetu otkrivenom 1966. godine (o kojem je pisao Benac), donijeti detaljnije informacije o samoj butmirskoj kulturi, ulozi koju je naselje u Okolištu imalo i o organizaciji naselja kasnog neolita.

Iz navedenog proizilazi nekoliko hipoteza koje su bile zastupljene tokom sedamdesetih godina 20 . stoljeća i koje pokazuju sumarne zaključke do kojih su tadašnji arheolozi došli. Prije svega, kada je u

\footnotetext{
14 Naselja Obre I i Obre II nisu dva horizonta jednog položaja, već dva različita položaja. Nažalost, zbog parcijalne istraženosti ne može se sa sigurnošću odrediti da li se radi o jednom lokalitetu ili o odvojenim naseljima. To je važno naglasiti iz razloga što te dvije sonde zapravo pružaju podake o različitim materijalima.

15 Slabije je zastupljena i keramika jadranskog tipa, kao i crnoglačana roba. Jedino je spiralno-trakasta keramika srodna u oba naselja, jer je spiraloidna keramika zapravo posebnost butmirske kulture (Benac 1971: 138).

16 Većina nalaza plastične umjetnosti iz Butmira odnosi se na ljudske figure, a samo mali broj na životinjske. One su izrađene sa velikom pažnjom, pretežno u crnoglačanoj tehnici. Jedan broj sačuvanih glava ljudskih figura pokazuje određene osobine realistične umjetnosti. U crtama lica, obliku glave, nosa, čela te u predstavi kose kao da se naziru pripadnici tri rasna tipa: armenoidi, negroidi i europeidi, alpski tip (Benac 1979: 437).
} 
pitanju sam početak mlađeg kamenog doba odnosno neolita na prostoru Balkana, uzimaju se uglavnom one ideje koje pretpostavljaju širenje neolitskih zajednica sa istoka. Taj proces "neolitske revolucije" ${ }^{17}$ bio je postepen i trajao je dugo vremena. Prema Benčevim riječima, Bosna je u starijem neolitskom periodu bila nenastanjena, vjerovatno zbog promjene klime nakon mezolita odnosno srednjeg kamenog doba, ili jednostavno do tada nisu pronađeni tragovi života iz ovog perioda, što je Benac smatrao puno izvjesnijim. Danas je poznato kako je veći dio Evrope oko 7.000 godina pr. n. e. bio naseljen sakupljačko-lovačkim zajednicama, dok je otprilike u istom periodu na prostoru jugozapadne Azije već započeo proces sjedilačkog načina života.

Nakon objave PJZ krajem sedamdesetih godina 20. stoljeća, proučavanje neolita Bosne i Hercegovine je u blagom opadanju zbog raspada Jugoslavije i ratnih zbivanja na ovom prostoru. Ipak, u godinama stabilizacije i napretka države osjeća se i napredak u nauci, ponajviše zahvaljujući modernoj tehnologiji. Krajem osamdesetih objavljen je Arheološki leksikon Bosne i Hercegovine u tri toma, koji zajedno sa $P J Z$ predstavlja monumentalno djelo najvećih arheologa tadašnjeg vremena. U prvom tomu Leksikona prikazana je Bosna i Hercegovina u prahistoriji, antici i srednjovjekovnom periodu, zajedno sa leksikografskim dijelom (Leksikon I 1988: 15-190). Prostor Bosne podijeljen je na 25 regija unutar kojih su nabrojana i ukratko objašnjena sva naselja i lokaliteti koji se odnose na navedene periode. ${ }^{18}$ Hronološki posmatrano, neolit Bosne i Hercegovine je krajem 20. stoljeća smješten u vremenski period od 6 . do početka 3. milenija, najraniji je period direktno zavisio od centralnobalkanskog odnosno jadranskog uticaja, da bi kasniji razvoj imao karakter formiranja originalnih kulturnih manifestacija (Leksikon I 1988: 18).

Regija 7, odnosno sjeveroistočna Bosna, u postratnom je periodu doživjela zatišje u literarnom, a posebno u terenskom dijelu. Izvršen je mali broj iskopavanja od kojih većina nije objavljena, kao što je to bio slučaj i sa Gornjom Tuzlom. Kako je već navedeno, lokalitet Gornju Tuzlu otkrio je Basler, a Čović je istražio i objavio poveći članak u kojem podrobno opisuje stratume, hronologiju, tipologiju, tehnologiju itd. Tek 2007. godine realizira se projekat pod pokroviteljstvom JU Muzej Istočne Bosne Tuzla, koji je predvodila Zilka Kujundžić-Vejzagić u svojstvu arheologa i muzejskog savjetnika Zemaljskog muzeja Bosne i Hercegovine u Sarajevu, u saradnji sa austrijskim Institutom za arheologiju koji su predstavljali Andreas Lippert i George Tiefengraber. U toku višegodišnjeg iskopavanja otvoreno je nekoliko sondi, ali rezultati nažalost nikada nisu objavljeni izuzev jednog

\footnotetext{
17 Gordon Childe je promjenu načina života od lovačko-sakupljačkih zajednica do uvođenja trajnih naselja i širenja poljoprivrede kao glavne privredne grane shvatio kao proces do kojeg je moglo doći isključivo revolucijom. Ipak, danas je prihvaćena hipoteza kako je navedena promjena bila postepena i dugotrajna, pa je proces nazvan neolitizacija (TežakGregl 2014: 7).

18 Prostor sjeveroistočne Bosne pripada tomu II, regija 7 (Leksikon II 1988: 101).
} 
kratkog članka objavljenog 2017. godine, koji se osvrće na radiokarbonsku analizu (KujundžićVejzagić, Lippert, Tiefengraber, Bakalović 2017: 148). Terenska dokumentacija i iskopani materijal nalaze se u Muzeju Istočne Bosne u Tuzli i bit će podvrgnuti detaljnoj analizi i komparaciji sa najnovijim istraživanjem na prostoru Gornje Tuzle, provedenim u augustu 2018. godine. Jedan od najvećih doprinosa proučavanju prahistorijske arheologije sjeveroistočne Bosne dala je arheologinja Milica Kosorić, dugogodišnja uposlenica Muzeja Istočne Bosne u Tuzli. Njezini istraživački radovi na lokalitetima u području Spreče (Korića Han, Lug, Vuknići) i na ostalim lokalitetima poput Batkovića kod Bijeljine, Brda u Donjoj Mahali kod Orašja, Dobrovca, Dvorišta na Drinjači kod Zvornika i dr. (Kosorić 1980: 103; Kosorić 1990: 27), značajno su doprinijeli u istraživanju neolita sjeveroistočne Bosne. Potrebno je izdvojiti radove Nikole Tasića koji je, proučavajući starčevačku kulturu i ulogu soli u životu neolitskih populacija, veoma često pisao o sjeveroistočnoj Bosni i o dva starčevačka naselja, Gornjoj Tuzli i Obre I u centralnoj zoni, kao jedinim naseljima starčevačkog kompleksa na prostoru Bosne i Hercegovine. Nije se značajnije uplitao u analize dosadašnjih zaključaka s ozbirom na (kako je i sam naveo) nedovoljnu istraženost lokaliteta. Spomenuo je moguću komunikacionu liniju između dva naselja uzmimajući sol kao najvjerovatniji predmet trgovine te iznio zaključak da je, sudeći prema $\mathrm{C}_{14}$ nalazima, naselje Obre I nešto mlađe od Gornje Tuzle (Tasić 2007: 11).

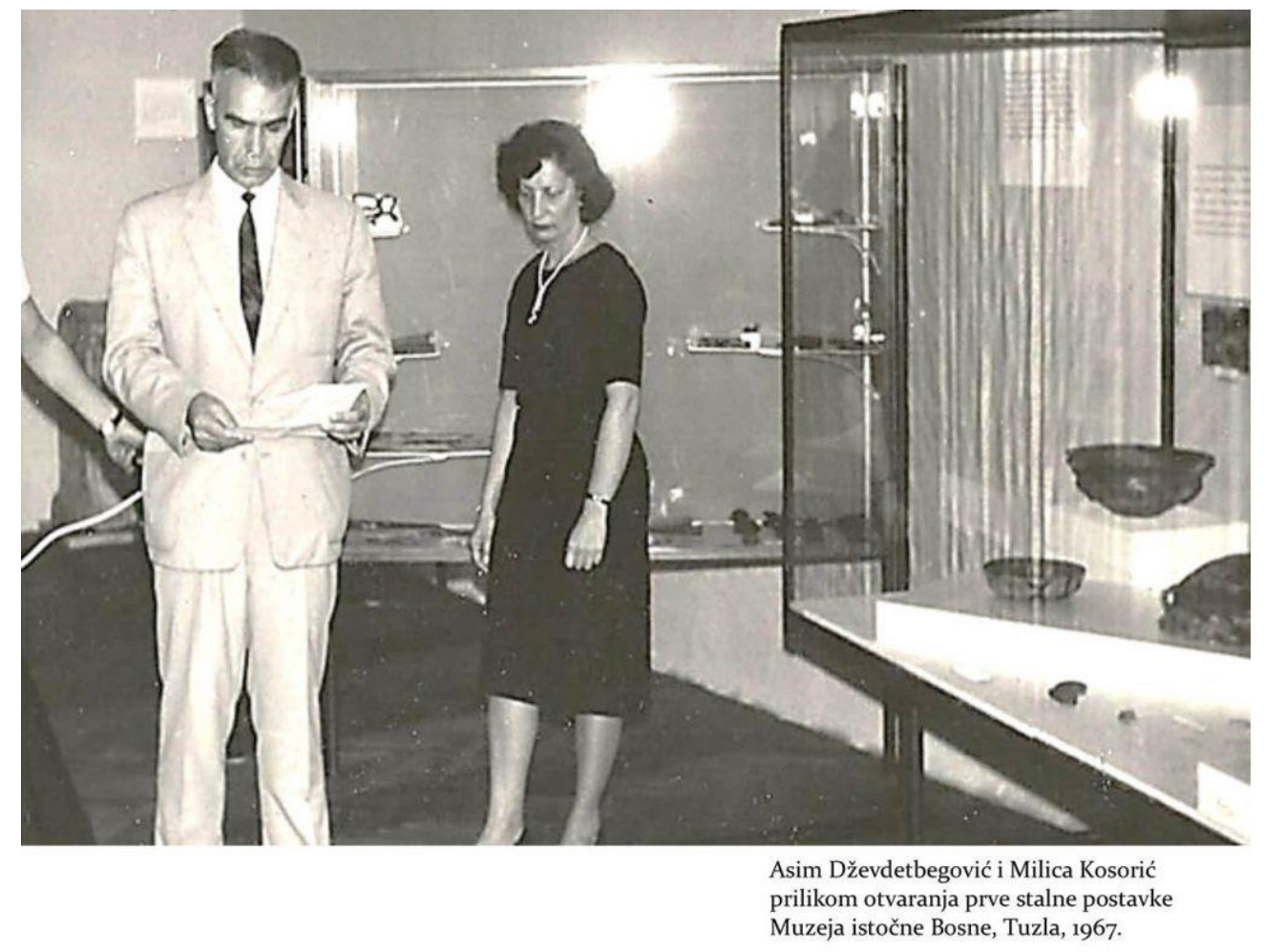

Slika 5. Milica Kosorić (http://muzejibtuzla.podkonac.org/o-muzeju/) 
Najznačajnija istraživanja od kraja 20. stoljeća do danas rađena su u centralnoj zoni, gdje su razmatrane ranije ideje i doneseni noviji zaključci. Veliku ulogu u tome imao je arheolog Slaviša Perić koji je svojim istraživanjem o butmirskoj kulturi proširio dotadašnja saznanja i preispitao ranije tvrdnje, poput Benčeve o postojanju samostalne kakanjske kulture koju je Perić definisao fazom Protobutmir Ia (Perić 1985-86: 15; Perić 1995: 79; Perić 2012: 21). Pored Slaviše Perića, problematikom butmirske kulture bavila se i Zilka Kujundžić-Vejzagić izučavajući Okolište i ranu metalurgiju u centralnoj Bosni (Kujundžić-Vejzagić, Müller, Rassman, Schüler 2004: 13; Kujundžić-Vejzagić 2008: 23). Ona je također učestvovala u radovima najbolje istraženog lokaliteta centralne zone, naselja Okolište, u saradnji sa austrijskim stručnjacima (Robert Hofmann, Johannes Müller, Knut Rassmann, Nils Müller-Scheessel). Njihovi radovi o rekonstrukciji kasnoneolitičkih procesa naseljavanja centralne Bosne i lokaliteta Okolište predstavljaju vrhunac istraživanja jednog naselja prema modernim standardima nauke (Hofmann, Kujundžić-Vejzagić, Müller, Rassmann, Müller-Scheessel 2009: 11). Najnovija istraživanja na Butmiru radio je Adnan Kaljanac u sklopu istraživanja preventivne prospekcije arheološkog potencijala na lokalitetu nacionalnog spomenika iz 2015. godine, ${ }^{19}$ što je predstavljalo prvu fazu arheološkog istraživanja kao prethodnicu sistematskim istraživanjima. ${ }^{20}$ Kada je u pitanju južna zona, potrebno je spomenuti Brunislava Marijanovića koji se u svojim radovima detaljnije osvrtao na ranije zaključke o neolitiku jadranskog područja i hercegovačkog dijela Bosne i Hercegovine te o značaju vode, u ovom slučaju Neretve, pri naseljavanju ovog prostora.

\footnotetext{
${ }^{19}$ Plan preventivne prospekcije arheološkog potencijala na lokalitetu nacionalnog spomenika Arheološko područje prahistorijsko naselje u Butmiru, općina Ilidža (Faza 1) (Sarajevo, 2015.).

${ }^{20}$ Rezultati arheološke prospekcije objavljeni su 2017. godine u Godišnjaku (Kaljanac 2017: 19).
} 


\section{Neolit BiH - vanjski uticaji na formiranje kulturnih gupa}

\section{3a Južna zona}

Period mlađeg kamenog doba na teritoriji današnje Bosne i Hercegovine usko je vezan za susjedne oblasti, odakle su dopirali razni uticaji koji su se širili i uspostavljali temelje razvoja neolitskih kultura. Veoma često takvi su uticaji predstavljali baze za međusobno miješanje i ispreplitanje, što je za posljedicu uglavnom imalo stvaranje kultura i naselja sa karakteristikama matičnog područja, odakle su se ti uticaji prvobitno i širili. Na taj način dolazi do poprimanja nekih od bitnijih osobina jedne kulturne grupe unutar druge, $\mathrm{u}$ zavisnosti od nivoa uticaja jedne odnosno druge kulture. $\mathrm{U}$ nekim slučajevima takav proces asimilacije nije igrao značajniju ulogu, nego su uglavnom uticaji jedne kulturne grupe bili superiorniji prema drugoj, što je rezultiralo promjenama u keramografiji, načinu života $\mathrm{i} \mathrm{sl.}^{21}$ Upravo iz tog razloga je prostor današnje Bosne i Hercegovine bio sklon uticajama, ne samo sa Jadrana nego i iz kontinentalnog dijela Hrvatske te istočne Srbije, srednje Evrope i jugoistočnog Balkana, iz područja koja su kulturološkim propagiranjem širila pogodnosti vlastitog razvoja i napretka. Oblik tla, građa i reljef prostora, sredozemna klima i pristup Jadranskom moru, što je otvaralo pristup unutrašnjim i vanjskim komunikacijama (Batović 1979: 471), činili su prostor današnje Dalmacije veoma pogodnim za nastanak i razvoj neolitskih kultura (ponajviše u privrednom smislu), odakle se nešto kasnije vršio kulturni uticaj dublje u unutrašnjost.

21 Počeci tranzicije poljoprivrede jugoistočne Evrope vežu se za agrikulturalne zajednice koje su stvorile neolitsku dijasporu, kroz koju se uzgoj poljoprivrednih kultura i životinja raširio kroz cijeli region. Farmeri koji su migrirali sa sobom su donijeli nove tehnologije i simbole, a pojava keramografije shvaćena je kao značajna distinkcija između kasnomezolitskih i ranoneolitskih kultura. (Budja 2014: 71). 


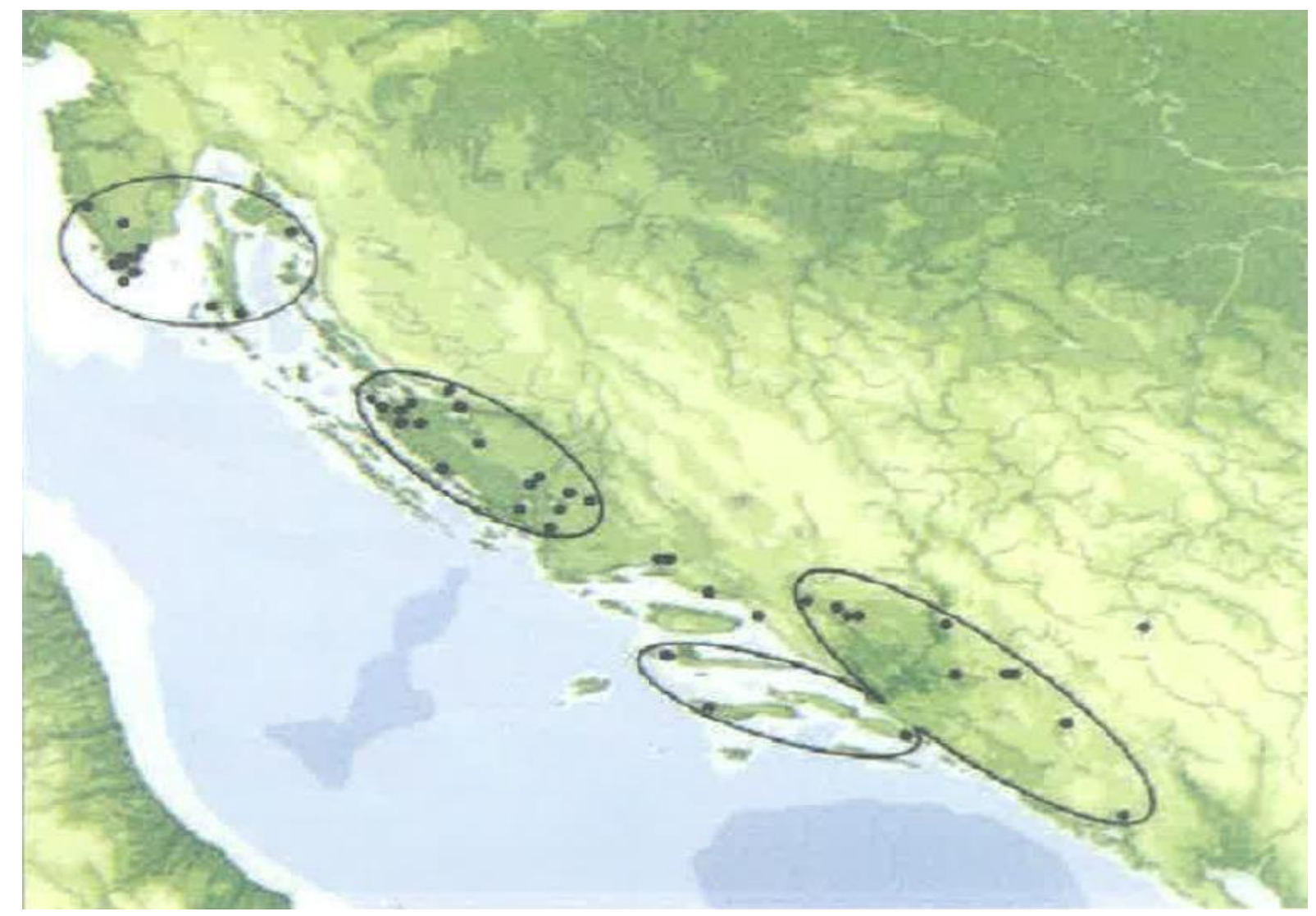

Slika 6. Hercegovina u sklopu istočnog jadranskog kompleksa. Hercegovina pripada južnoj cjelini (Marijanović 2007: 16)

Geografski posmatrano, jadranskom zaleđu bi pripadao prostor današnje Hercegovine koja je u ranim periodima neolita bila pod značajnim uticajima nosilaca impresso kulture. Većina hercegovačkih polja bila je izložena dugotrajnim taloženjima i poremećajima naslaga zemlje, pa su tokom glacijalnog perioda pod uticajem vode veoma često poprimala neplodne naslage koje su naposlijetku činile bitan faktor za određivanje nivoa ekonomske stabilnosti zasnovane na poljoprivrednoj proizvodnji (Marijanović 1983: 68). Međutim, lovačko - stočarska privreda nije oskudijevala u tom smislu, posebno kada su u pitanju Lisičići i Ravlića pećina, (Marijanović 1981: 11) gdje je zemljoradnja činila samo sporedni izvor egzistencije. Karakter privrede starijeg neolita Hercegovine nije bitno izmijenjen u odnosu na prethodni, mezolitski period, i konstantno traganje za boljim načinom života i drugačijim izvorima egzistencije daje pečat čitavom načinu života, usmjeravajući ga na taj način na nešto specifičniji sjedilački život ${ }^{22}$ u odnosu na područje centralne i sjeveroistočne Bosne, gdje je čovjek od najranijih perioda gradio naselja na otvorenom sa akcentom na zemljoradničkoj privredi zajedno sa lovačkom komponentom. Tokom starijeg neolita

22 Prema Šimi Batoviću, koji je analizirao ekonomske osnove starijeg neolita Jadrana, područja u koje je ubrajao i prostor Hercegovine, zemljoradnja kao osnovni faktor stalnog sjedilačkog načina života uzima maha tek u II. fazi impresso kulture (Batović 1979: 510.) Takav proces je rezultirao napuštanjem privremenih pećinskih skloništa i osnivanjem većeg broja naselja na otvorenom. 
Hercegovina je, dakle, u značajnoj mjeri bila uključena u neposredne dodire sa nosiocima impresso kulture sa Jadrana, što se nastavilo za vrijeme srednjeg neolita kada je najzastupljenija kultura bila danilska, odnosno mlađi neolit i period hvarsko - lisičićke kulture.

Na osnovu rezultata novijih arheoloških istraživanja u Bosni i Hercegovini, može se konstatovati da je period starijeg neolita zastupljen samo na prostoru Hercegovine, koja u širem geografskom smislu pripada južnoj cjelini istočnog jadranskog kompleksa. Uglavnom je riječ o pećinskim naseljima (Zelena pećina, Ravlića pećina i dr.) koja su usko vezana za kršovite i brdovite predjele, i gdje se uglavnom prati tradicija mezolitskog perioda sa osnovom u lovačkoj komponenti privrede, što najbolje dokazuju mnogobrojni ostaci divljih životinja (Pandžić 2014: 81). Zasad nije poznato niti jedno pećinsko nalazište iz starijeg neolita sa ostacima cerealija, što je vjerovatno posljedica neobradivog i neplodnog terena na kojem su ove zajednice živjele (Marijanović 2007: 7). Pored pećinskih naselja, poznata su i standardna naselja na otvorenom (Čairi kod Stoca, Vukove njive kod Posušja i dr.), na kojima su pronađeni ostaci cerealija odnosno najmanje dvije vrste žitarica (Triticum monococcum i Triticum dicoccum) i uglavnom ostaci domaćih životinja (Marijanović, 2007: 29 32), što ukazuje na razlike u privredi ovih tipova naselja. Najstariji tragovi ranog neolita na području današnje Bosne i Hercegovine nalaze se, dakle, na prostoru Hercegovine gdje se iz mezolitskih supstrata razvijaju neolitske kulture, isprva nastanjene u pećinama uglavnom sa karakterom kratkotrajnog zadržavanja, a nešto kasnije i pod otvorenim nebom. Osnovni demografski nosioc svih razvojnih procesa tokom starijeg neolita ovog područja jeste zapravo autohtoni mezolitski supstrat, s obzirom na to da je na prostoru istočnojadranske zone sa Hercegovinom dokazana prisutnost mezolitskih populacija na nekoliko značajnih nalazišta, poput Crvene stijene i Crnog Vrila (Marijanović 2009: 26 - 74; Marijanović 2013: 80) za razliku od ostatka Bosne a onda i susjednih regija, za koje zasada nema podataka o takvim tragovima (Pandžić 2014: 82).

Nosioci impresso kulture, nastale na autohtonim mezolitskim supstratima jadranske obale, tokom II. faze razvoja impresso kulture na Jadranu ostvarili su kulturne dodire sa stanovništvom Hercegovine. ${ }^{23} \mathrm{U}$ odnosu na jadransku obalu, impresso kultura starijeg neolita Hercegovine imala je nešto drugačije osobine koje su se najviše uočavale u nedostatku ornamentike izvedene utiskivanjem ruba školjke cardium, iz prostog razloga što je nedostatak tih školjaka dublje u kontinentalnim predjelima bio značajan u odnosu na obalna područja. Ukoliko se, dakle, uzme u obzir podatak da se kardium impresso kultura javlja na prostoru Hercegovine u svojoj drugoj, zreloj fazi te da ima određene specifičnosti koje se najbolje ogledaju u nedostatku kardium školjki, koje s druge strane

23 Zrelu, odnosno II fazu impresso kulture, odlikuje utiskivanje prstom ili noktom te monohromna siva i smeđa keramika. 
čine jednu od značajnijih osnova razvoja kulture, onda se može zaključiti da impresso kultura ne predstavlja autohtonu komponentu, nego je vjerovatno dolinom rijeke Neretve tokom migracija dospjela na prostor Hercegovine. Već u narednoj fazi impresso kulture na Jadranu, odnosno u III. kasnoj fazi, na prostoru Hercegovine ona doživljava svoj vrhunac i nastavlja ekspanziju, započetu u prethodnoj fazi sa prostora Jadrana. Uticaji sa Jadrana nisu prestali ni tokom prelaznog perioda iz starijeg u srednji neolit - na osnovama impresso kulture razvija se nova, danilska kultura srednjeg neolita koja je bila raširena uglavnom na istom području kao i impresso (Batović 1979: 524). Na prostoru Hercegovine dolazi do formiranja značajnih naselja koja u osnovi imaju karakteristike impresso kulture, a od kojih je većina nastavila životni vijek za vrijeme srednjeg, pod uticajem danilske kulture, te mlađeg neolita, pod uticajem hvarsko - lisičićke kulture.

Neka od najznačajnijih naselja iz najstarijeg perioda neolita svakako su pećine poput Ravlića pećine i Hateljske pećine, na kojima se prati dugotrajni proces života neolitskog čovjeka. Višeslojno nalazište Ravlića pećina (Marijanović 2008: 141 - 145; Marijanović 2012: 7 - 107) nalazi se na izvoru rijeke Tihaljine u zapadnom dijelu Hercegovine, i karakteristično je prije svega iz razloga što ne postoje stratigrafski slojevi koji bi potvrdili život u periodu srednjeg neolita, što bi značilo da je pećina neposredno nakon završetka impresso kulture bila napuštena, te u nešto kasnijem periodu ponovo naseljena iz dosad nepoznatih razloga. Prema Marijanoviću, prve dvije faze pripadaju neolitskom periodu: na dubini do 3,5 m nalaze se ostaci starije impresso kulture, a od 3,5 do $2 \mathrm{~m}$ dubine konstatovana je faza prelaza iz mlađeg neolita u eneolit (Marijanović 1981: 18). Sloj impresso kulture je tanak, što znači da je ta faza trajala kratko, o čemu svjedoči i ograničen broj nalaza. Ipak, Marijanović pretpostavlja da se radi o važnom lokalitetu s obzirom na to da se na osnovu ornamentike može potvrditi prije svega pripadnost impresso kulturi u cjelini, a onda i direktna analogija sa materijalom iz Smilčića i zrelom fazom impresso kulture sa kojom se i povezuje najstarija faza Ravlića pećine (Marijanović 1981: 44). Lokalitet Hateljska pećina nalazi se kod Stoca u istočnoj Hercegovini i naselje je sa dugotrajnim periodom života, s tim da je, kao i u slučaju Ravlića pećine, život za vrijeme srednjeg neolita zasad nepoznat. Utvrđena je jasna stratigrafija pet razvojnih faza, i to: period starijeg i mlađeg neolita, eneolit, rano i srednje bronzano doba (Marijanović 2000: 195). ${ }^{24}$ Najstarija faza naselja pripada impresso kulturi starijeg neolita i sadrži keramički materijal tipičan za neolit Jadrana i zaleđa, ali i keramički materijal za koji Marijanović kaže da ima regionalna obilježja i da je usko vezan za III. fazu lokaliteta Zelena pećina koja se nalazi kod Blagaja, na rijeci Buni. Keramografska srodnost Hateljske i Zelene pećine

\footnotetext{
${ }^{24}$ Izdvojen je i mali broj nalaza koji pripadaju periodu srednjeg vijeka, pa se na osnovu navedenih stratigrafskih faza može uočiti prekid života u Hateljskoj pećini u dva navrata, u periodu između starijeg i mlađeg neolita te od bronzanog doba do srednjeg vijeka.
} 
najuočljivija je u ukrašavanju posuda redovima polukrugova te uglastih i izduženih štapićastih motiva u tehnici gustog utiskivanja (Marijanović 2000: 195). ${ }^{25}$ Marijanović zaključuje da je u istočnoj Hercegovini postojala posebna impresso varijanta u sklopu jadranske impresso kulture. Pored karakterističnih regionalnih obilježja, rana faza Hateljske pećine karateristična je i zbog pronađenih primjeraka slikane i barbotin keramike starčevačkog tipa, koji se ipak pripisuju samo importu a ne značajnijim kulturološkim posebnostima. U poređenju sa impresso kulturom na Jadranu, najranija faza Hateljske pećine hronološki se vezuje za prelaz iz zrele u kasnu fazu impresso kulture (Marijanović 2000: 196).

Vrijedi spomenuti i lokalitet Žukovačka pećina kod Posušja, koji je najvjerovatnije imao karakter naselja kratkotrajnog zadržavanja s obzirom na to da se primjećuje nedostatak podataka o stratigrafiji. Analizom pronađene skromne količine keramičkih nalaza utvrđeno je da je riječ o impresso keramici ukrašenoj utistivanjem, urezivanjem i žigosanjem (Marijanović 1978: 5).

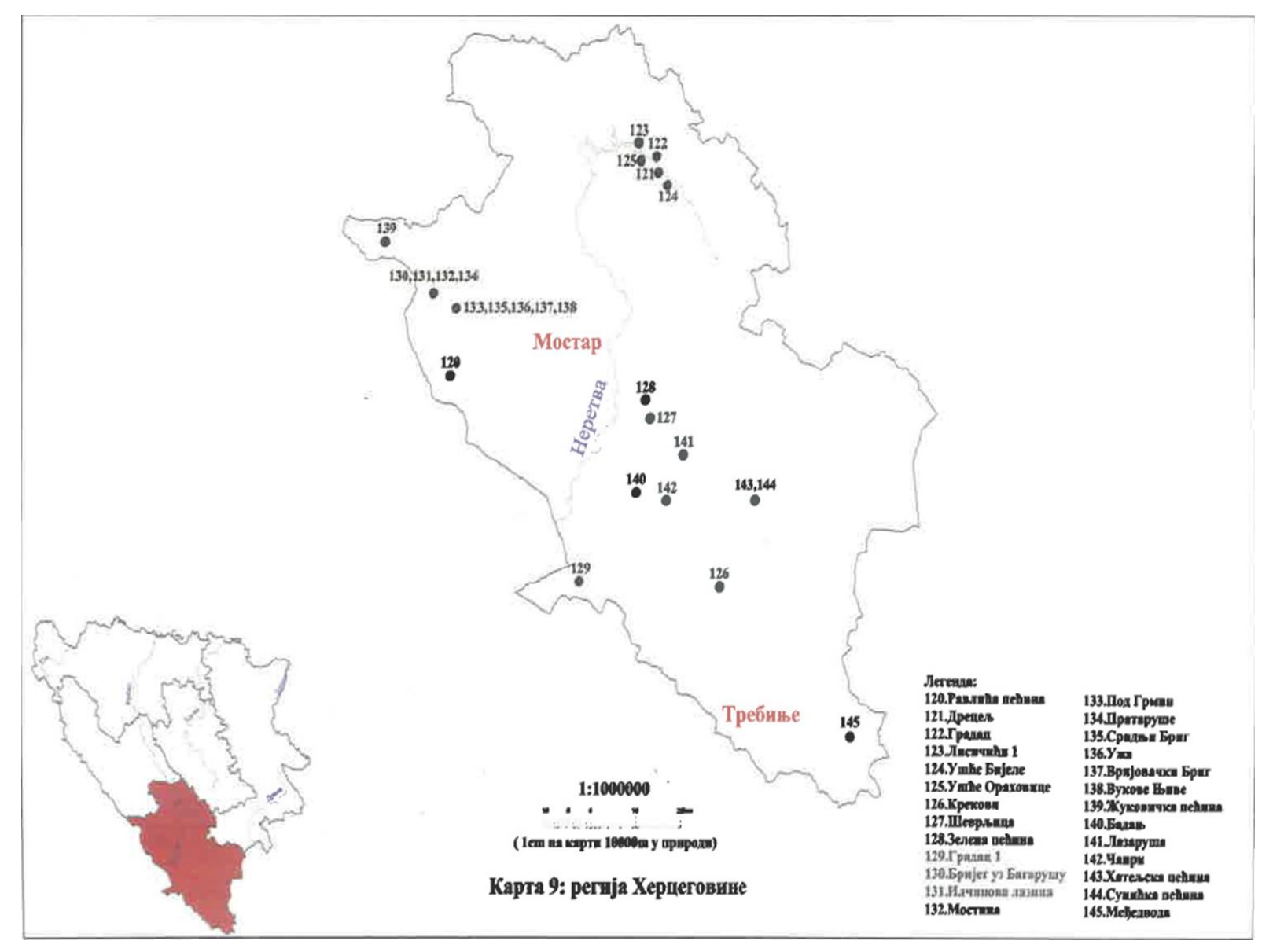

Slika 7. Regija Hercegovine (Pandžić 2014: 151)

25 Ipak postoje i neke razlike između ove dvije pećine, a one se očituju u pojavi motiva izvedenog utiskivanjem ruba školjke u Hateljskoj pećini, što je karateristično za Jadran, a što u potpunosti nedostaje u Zelenoj pećini. 
Detektovanje impresso kulture starijeg neolita Hercegovine nije potvrđeno samo na pećinskim lokalitetima, nego i na otvorenim naseljima poput Čairi kod Stoca te Vukove njive kod Posušja. Na lokalitetu Čairi kod Stoca utvrđen je sloj za koji se vjeruje da potiče iz mezolitskog perioda, na osnovu pronađenih kremenih nukleusa, mikrolitskih kamenih oruđa i bezkeramičkih nalaza, dok je iznad njega utvrđen nešto mlađi sloj sa keramičkim ostacima impresso kulture. U neolitskom sloju prevladavaju fina i bojena keramika bez ornamenata, te monohromni fragmenti i manji komadi sa urezanim ornamentalnim motivima, koji predstavljaju neke od karakteristika srednjeneolitske danilske kulture (Pandžić 2014: 67) Na ovom se lokalitetu, dakle, prati kontinuiran život sa tankim kulturnim slojem srodnim danilskoj kulturi, na osnovu čega se može utvrditi prelaz iz ranog u srednji neolit. Za lokalitet Vukove njive kod Posušja je na osnovu nalaza iz relativno plitkog sloja utvrđena pripadnost impresso kulturi u širem smislu. Keramički materijal je nešto slabijeg kvaliteta, bez primjese, sa primarnim odlikama impresso ukrašavanja. Prema Marijanoviću, posmatrano iz hronološkog aspekta lokalitet Vukove njive je nešto stariji od lokaliteta Smilčića i Zelene pećine, što bi ga svrstalo u okvire rane faze impresso kulture u Hercegovini (Marijanović 1978: 12). 


\section{3b Centralna zona}

Nakon što su naselili Hercegovinu, nosioci impresso kulture prodrli su dolinom rijeke Neretve u nešto sjevernije predjele kako bi se naselili na lokalitetu Obre I u centralnoj Bosni. Taj proces bio je dugotrajan i nosioci impresso kulture su na ovom lokalitetu stupili u neku vrstu simbioze sa pripadnicima starčevačkog kompleksa, koji su do ovog lokaliteta došli dolinom rijeke Bosne. Kao posljedica kontakta dvije geografski udaljene kulture, razvija se jedna regionalna kulturna grupa na čijim se ostacima primjećuju identifikacijske karakteristike impresso i starčevačke kulture i koju je Benac okarakterisao terminom stačevačko - impresso kultura (Benac 1973: 63). Nosioci starčevačke kulture sa sobom su donijeli sve elemente izvorne kulture: barbotin keramiku, žrtvenike starčevačkog tipa, grubu keramiku sa urezanim ornamentima, finu slikanu keramiku, kao i neke tipične plastične proizvode. $\mathrm{S}$ druge strane, jadranska komponenta pruža nešto drugačiju sliku uglavnom su pronađeni brojni primjerci fine keramike sa tremolo ornamentima, kao i grube keramike sa ukrasima izvedenim noktom. Ipak, u potpunosti nedostaju primjerci grube keramike sa raznovrsnim impresso motivima izvedenim rubom školjke, što predstavlja glavnu odliku impresso kulture (Benac 1973: 63). Na osnovu analize keramike nađene u ovakvom omjeru, gdje je uglavnom riječ o keramici starčevačkog tipa obogaćenoj elementima jadranske impresso kulture, pretpostavlja se da su nosioci starčevačke komponente imali veću ulogu pri formiranju naselja (Benac 1979: 388). Ono što se može potvrditi sa sigurnošću jeste činjenica da su prva drva stratuma naselja Obre I najstarija u centralnoj Bosni, te da je riječ o kulturnoj grupi nastaloj pod uticajem migracionih kretanja. To automatski isključuje bilo kakvu ideju o autohtonom razvoju, s obzirom na to da je naselje locirano na perifernim dijelovima impresso kulturnog kompleksa, ali i onog starčevačkog.

U I. fazi lokaliteta Obre I materijal starčevačke kulture uglavnom je predstavljen osnovnim karakteristikama iste kulture na generalnom niovu. Riječ je o barbotin keramici koja je u I. fazi najbrojnija i najdominantnija keramička vrsta, ${ }^{26}$ zatim o dijelovima jednog žrtvenika sa četiri noge, običnoj gruboj keramici uglavnom crvenkaste boje i vjerovatno trbušastog oblika sa ravnim dnom, te o bojenoj keramici koja spada u finu starčevačku keramičku robu (Benac 1973: 51). ${ }^{27} \mathrm{~S}$ druge strane, keramika impresso kulture se u značajnoj mjeri razlikuje od starčevačke i uglavnom spada u finu keramiku. Površina vaza je relativno dobro glačana, a ponekad i prevučena sjajnim crnim premazom

\footnotetext{
${ }^{26}$ Najčešći oblik barbotinske robe je trbušasta vaza sa manje ili više izvijenim rubom i prstenastom nogom ili sa ravnim dnom, te nešto rjeđe trbušasta vaza sa cilindričnim vratom. Drške su relativno rijetke i obično su trakaste, dok je ornamentalni sistem uglavnom zastupljen kaneliranim barbotinskim elementima izvedenim povlačenjem prstiju preko vlažne gline.

27 Obično je riječ o kombinaciji dva motiva (snopovi okomitih linija i prepleti s okvirom od debljih okomitih linija), zastupljenih na koničnoj zdjeli na prstenastoj nozi, peharu na prstenastoj nozi i visokoj šolji sa naglašenim trbuhom.
} 
kako bi dobila tamnu boju, relativno sličnu vinčanskoj keramici sa kojom u svakom slučaju nije vezana ni na bilo koji način. Kao što je ranije navedeno, ornamenti (odnosno tremolo motivi) su uglavnom rađeni rubom morske školjke (Benac 1973: 52). Situacija u narednoj, II. fazi naselja Obre I, uglavnom je slična ali na osnovu nekih detalja razlikuje se od prethodne. Keramika starčevačkog tipa i dalje je procentualno zastupljenija, ali uz osjetan porast uticaja impresso komponente. Barbotin keramika starčevačkog tipa i dalje dominira, uz znatan tehnološki napredak s obzirom na to da se više ne koristi samo pljeva nego i pijesak u glini, što je dodatno utjecalo na čvrstoću zidova posuda, a pojavljuje se i tamna odnosno crna barbotinska robea ${ }^{28}$ U II. fazi ostaci starčevačkih žrtvenika nešto su brojniji u odnosu na prethodnu fazu, glavni dijelovi žrtvenika i dalje su četiri noge uglavnom trouglastog presjeka, a kod grube keramike primjećuje se porast upotrebe pijeska u fakturi, te tamne, tamnosive i tamnosmeđe boje, ${ }^{29}$ dok bojena keramika nije doživjela bitnije promjene. Nalazi impresso keramike daleko su bogatiji u odnosu na prethodnu fazu. Faktura tankih zidova i dalje je jednobojna, tamnosiva, crna i sivosmeđa. Oblici su dosta jednostavni i svode se na više ili niže konične posude sa uvijenim središnjim dijelom, dok su tremolo ukrasi i dalje najkarakterističniji oblik ornamentalnog sistema. ${ }^{30} \mathrm{~S}$ obzirom na karakteristike keramičkog materijala najstarijih faza naselja Obre I, zaključuje se da ove izdvojene faze ne predstavljaju ujedno i dvije razvojne faze kulture, što potvrđuju i poređenja sa srodnim nalazištima starčevačke i impresso kulture (Benac 1973: $67-77)$.

\footnotetext{
28 Najčešći oblici su trbušasti sudovi sa uvučenim ili izvijenim obodom, te trbušaste posude sa niskim cilindričnim vratom. Ornamentalni sistem je nešto razvijeniji, pa se II. faza naselja Obre I uzima kao vrhunac razvoja barbotin keramike. Najčešći su kanelirani vertikalni motivi.

${ }^{29}$ Među oblicima dominiraju veći lonci sa istaknutim trbušnim dijelom i izvijenim obodom. Drške se javljaju u tri varijante: obične trakaste drške, dvostruke trakaste drške i tunelaste drške.

30 Sitni pravi tremolo, široki tremolo koji liči na kardium motive, tremolo sa urezanom okomitom linijom, žigosane crtice koje liče na pravi tremolo, tremolo motivi koji podsjećaju na rad točkića i oni koji liče na jelovu grančicu. Motivi su redovno geometrijski.
} 


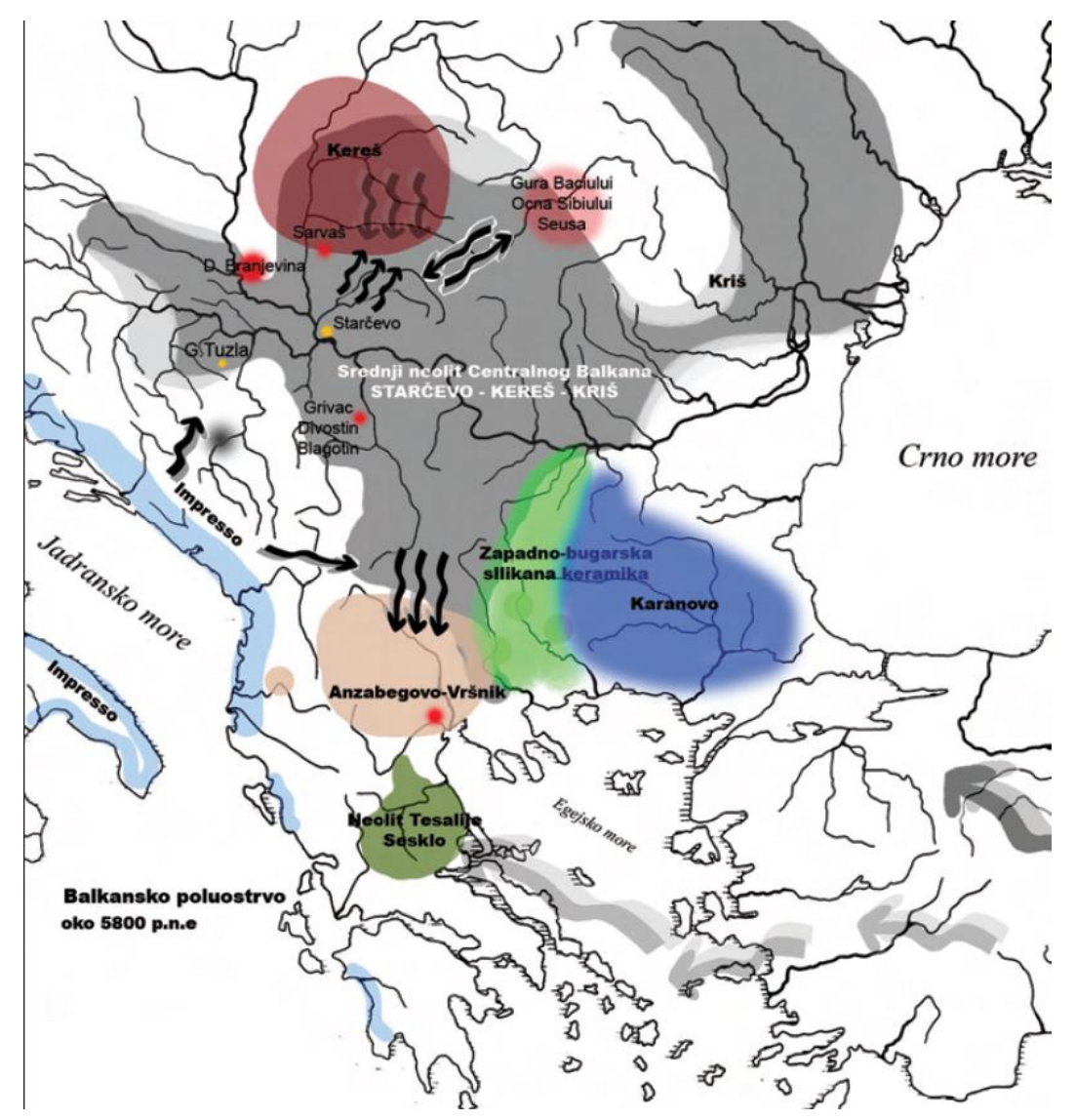

Slika 8. Balkansko poluostrvo oko 5.800 godine pr. n. e. i širenje impresso kulture prema centralnoj Bosni (Tasić 2007:

6)

Starčevačko-impresso kulturu, kako ju je definisao Benac nakon istraživanja na lokalitetu Obre I, isti je autor definisao kao kulturu starijeg neolita (Benac 1973: 5-171; 1979: 372). ${ }^{31}$ Kako je riječ o već unaprijed formiranim kulturnim grupacijama, uz činjenicu da je starčevačko-impresso kultura zastupljena jedino na lokalitetu Obre I, teško je govoriti o nekoj opštoj kulturnoj slici centralne Bosne toga vremena. Genezu nastanka ove kulture Benac tumači stanjem društvene organizacije $u$ neolitsko doba, zasnovane na principu egzogamnog braka odnosno zabrane ženidbe između članova iste rodovske zajednice (Benac 1979: 386-387), što implicira da su se ove relativno udaljene kulturne grupacije susrele i na taj način osigurale buduću egzistenciju. Ipak, na osnovu keramičkog materijala uočava se da je starčevačko-impresso kultura već unaprijed formirana kulturna grupacija sa obje keramografske karakteristike, izuzev pojave grube keramike impresso kulture, što također pokazuje da je riječ o ranije formiranoj kulturi (Perić 1995: 18) ${ }^{32}$ Ipak, kada je u pitanju odnos

\footnotetext{
${ }^{31}$ Prije nego li je vršeno istraživanje na lokalitetu Obre I, smatralo se kako prostor centralne Bosne nije bio naseljen u periodu prije formiranja kakanjske i butmirske kulture.

${ }^{32}$ Potvrdu za ovakvu tezu Perić pronalazi u Albaniji, gdje su izdvojene dvije faze definisane kao kulture Burim I (starija faza paralelna kraju Starčevo I i početak Starčevo IIa, bez primjese elemenata jadranske impreso kulture) i Kolš I (mlađa
} 
materijalnih nalaza prvog i drugog stratuma naselja Obre I prema starčevačkoj komponenti, uočava se da oni posjeduju sve elemente starčevačke kulture odnosno da se na lokalitetu Obre I dešava sličan proces zabilježen i u razvoju starčevačke kulture u njenim perifernim oblastima. U poređenju sa tim oblastima, keramika iz naselja Obre I najveće sličnosti na prostoru Bosne i Hercegovine ima sa najstarijim slojevima lokaliteta Gornja Tuzla (Čović 1961: 79), koji odgovaraju finalnoj fazi u razvoju starčevačke kulture (Garašanin 1979: 139). ${ }^{33}$ Uzimajući u obzir tvrdnje da materijal naselja Obre I pripada finalnoj fazi starčevačke kulture kao i materijal sa naselja Gornja Tuzla, onda ideja o starčevačko-impresso kulturi kao kulturi starijeg neolita nailazi na hronološke konfrontacije. Naime, na matičnom prostoru starčevačke kulture starijem se neolitu pripisuje samo njena prva faza, dok faza IIa obilježava rani, a faza IIb razvijeni srednji neolit (Garašanin 1979: 139-143). Kada je u pitanju jadranska komponenta na naselju Obre I, već je navedeno da se proces širenja impresso kulture do centralne Bosne odvija u njenoj finalnoj fazi, te da se na pojedinim lokalitetima karakterističnim za kraj jadranske impresso kulture javljaju elementi srednjeneolitske danilske kulture, uz činjenicu da se u mlađoj fazi u Albaniji, koja pripada srednjem neolitu, javljaju isti motivi na impresso keramici kao i u naselju Obre I. Nameće se zaključak (koji iznosi Perić) da starčevačkoimpresso kultura u naselju Obre I pripada periodu razvijenog srednjeg neolita, a ne starijeg neolita (Perić 1995: 19-20).

Ukoliko bi se tvrdnje Slaviše Perića ispostavile tačnima, ranija periodizacija neolitskih kultura po kojoj srednjem neolitu Bosne i Hercegovine (odnosno centralne Bosne) pripada kakanjska kultura a mlađem butmirska, onda se primjećuje određeni hronološki nesklad koji je potrebno razmotriti. Naime, u literaturi je ustavnovljeno da III. i IV. faza na lokalitetu Obre I pripadaju kakanjskoj kulturi (Benac 1979: 80). Na osnovu keramičkog materijala, odnosno potpunog gubitka impresso i starčevačke slikane keramike, Benac je primijetio pojavu nove kulture sa nekim novim elementima poput kultnih ritona (T. IV, 1-10), što bi impliciralo promjene u duhovnom načinu života. Zatim, kada je u pitanju monohromna keramika, koja je bila zapažena u prethodne dvije faze, Benac je naglasio da ona predstavlja ozbiljnog prethodnika nove kulturne faze koja će nastupiti sa III. fazom u naselju Obre I (Benac 1973: 56). Suština promjene koja se desila u Obrima tokom III. faze jeste nestanak impresso i slikane keramike, dok su se zadržale druge forme koje su procentualno bile zastupljenije, obična gruba barbotin i monohromna keramika, ${ }^{34}$ a nedostaje žutosmeđa keramika iz

faza koja odgovara Starčevo IIb), a zapravo se radi o dvije razvojne faze jedne varijante starčevačke kulture (Pandžić 2014: 49.)

33 Obre I/ I i II = Gornja Tuzla VI

34 Elementi novog kulturnog izraza zabilježeni su samo u okviru monohromne keramike, u ornamentalnom sistemu, pojavom urezanih i plastičnih motiva, dok je većina oblika starčevačko-impresso kulture, koja je bila zastupljena u okviru slikane i monohromne keramike, nastavila da egzistira i dalje, uz neke promjene (Perić 1995: 50). 
prehodnih slojeva - umjeso nje uvodi se u upotrebu keramika sa sjajnim crnim premazom (Benac 1973: 57-58). Ipak, Perić smatra da pojavu crnog premaza treba dovesti u vezu sa pokušajem podržavanja crnoglačane keramike, koja je u to vrijeme već u upotrebi u neolitskim grupama srednje Grčke i Tesalije, koja je dospjela i na matično područje starčevačke kulture i za koju će se ispostaviti da je osnovna karakteristika mlađe, vinčanske kulture. Perić smatra da se u tom pravcu trebaju posmatrati određene promjene konstatovane na osnovnim oblicima monohromne keramike u Obrima I, te navodi da bi se mogli preispitati Benčevi zaključci o razvoju protokakanjske i kakanjske kulture za vrijeme III. faze naselja Obre I. Također tvrdi da je neosnovana činjenica kako je III. stratum u Obrima I zaista obilježen pojavom novih elemenata materijalne i duhovne kulture, te ističe kako u istoj fazi još uvijek značajno mjesto (kada je u pitanju keramički materijal) pripada starčevačkoj kulturi (Perić 1995: 50-51).

Kao jedan od glavnih elemenata razvoja III. i IV. faze na Obrima I jeste potpuni nedostatak starčevačke keramike u IV. fazi (Benac 1979: 60-62.). ${ }^{35}$ Perić međutim navodi kako izostanak barbotin keramike treba u potpunosti odbaciti kao osnovu odvajanja III. i IV. faze, s obzirom na to da barbotin keramika i neki tipovi obične grube keramike predstavljaju bitnu komponentu na lokalitetima Plandište, Arnautovići i Okolište za koje se smatra da su mlađi od naselja Obre I (Perić 1995: 51), pa bi taj zaključak bio i logičan. Među zastupljenim oblicima IV. faze koji još uvijek vode porijeklo iz starčevačko-impresso kulture ustanovljena je samo jedna novina, a to je tip suda kruškolike forme sa cilindričnim vratom, koji uz zaobljene zdjele sa zadebljanim središnjim dijelom predstavlja oblik karakterističan za butmirsku kulturu (Perić 1995: 52). Elementi starčevačke i starčevačko-impresso kulture se, dakle, zadržavaju i u IV. fazi naselja Obre I, kada dolazi i do povećanja broja materijala sa elementima mlađeg balkansko-anadolskog kompleksa odnosno butmirske kulture (Pandžić 2014: 52). Na osnovu iznesenih tvrdnji Perić smatra kako stratumi III i IV u Obrima I predstavljaju postepeni prelaz iz starije starčevačko-impresso u mlađu butmirsku kulturu. Za razliku od matičnog područja starčevačke kulture, kamo su elementi balkanskoanadolskog kompleksa (odnosno vinčanska kultura) dospjeli nešto sporije, na lokaliteu Obre I dolazi do formiranja jedne prelazne faze koju Perić identifikuje kao protobutmirsku fazu. Samim time dovodi se u pitanje hronološki položaj kakanjske kulture, odnosno pitanje podjele kakanjske kulture na tri faze (ranog, srednjeg i kasnog srednjeg neolita), kako je to Benac ranije utvrdio (Benac 1973: 92).

\footnotetext{
35 Ipak, barbotin keramika nije u potpunosti nestala, ali je procentualno značajno opala, dok su kod grube keramike elementi starčevačke kulture i dalje dominantni (Perić 1995: 51).
} 

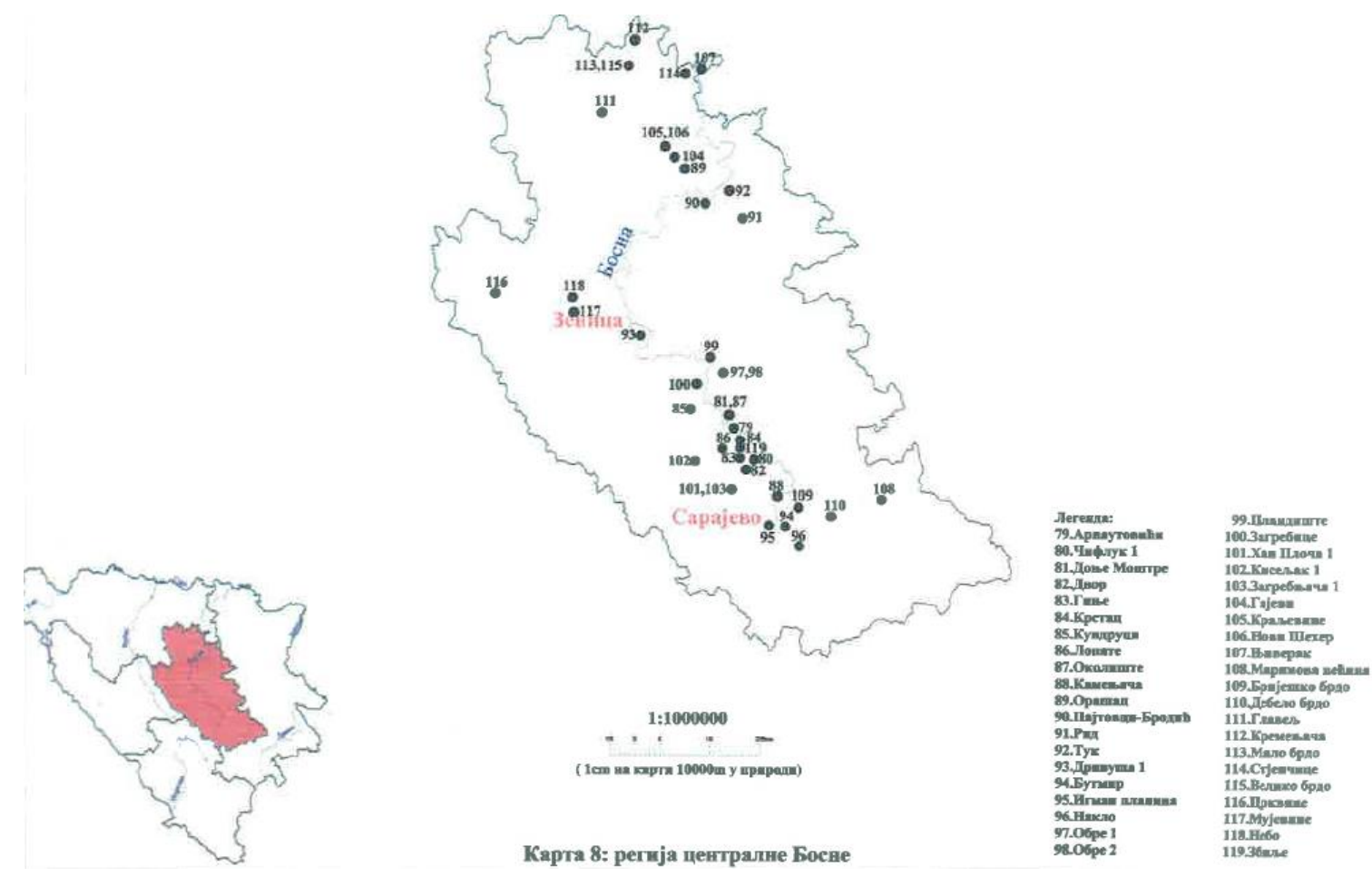

Slika 9. Regija centralne Bosne (Pandžić 2014: 149)

Prema podacima do kojih je došao Perić, prilikom analize materijala naselja za koja je utvrđeno da pripadaju kakanjskoj kulturi primjećuje se da kakanjski kulturni elementi egzistiraju u znatno užim hronološkim okvirima od onih u koje je kakanjsku kulturu smjestio Benac (Perić 1995: 78). Naime, u stratumu III i IV naselja Obre I uglavnom se radi o upotrebi sjajnog crnog premaza koji je podsjećao na crnoglačanu keramiku, ali je tek pri kraju stratuma IV pronađen jedan nalaz prave crnoglačane keramike ukrašene kanelurama, što je bila značajna odlika butmirske kulture. ${ }^{36} \mathrm{Na}$ drugim lokalitetima pripisanim kakanjskoj kulturi (Plandište, Arnautovići, Okolište i Zagrebnice) zabilježena je masovnija upotreba crnoglačane keramike, pa spiralne i trakaste keramike, što predstavlja tri osnovne komponente butmirske kulture. Prema tome, u naselju Obre I uglavnom je prisutna imitacija keramike sa metalnim sjajem, uz primjenu određenih oblika i ornamentalih motiva karakterističnih za butmirsku kulturu, dok se na ostalim lokalitetima primjećuje značajnija upotreba crnoglačane, spiralne i trakaste keramike. Ovakvo stanje zastupljenosti butmirskih elemanata na lokalitetima pripisivanim kakanjskoj kulturi predstavljaju osnovu za utvrđivanje kulturno-hronoloških odnosa (Perić 1995: 79).

\footnotetext{
${ }^{36}$ Kvantitet butmirskih elemenata na ovom lokalitetu nešto je veći tokom IV. faze u odnosu na prethodnu III. fazu. Ta je činjenica u suštini najizraženija razlika kulturnog sadržaja ove dvije faze.
} 
Imajući u vidu da hronološki okvir u kojem je mogla egzistirati kakanjska kultura obuhvata period od kraja impresso kulture do osnivanja naselja Obre II koje pripada butmirskoj kulturi, odnosno period srednjeg neolita, pojavljuje se realna sumnja o mogućnosti postojanja samostalne kakanjske kulture. Činjenica jeste da se kakanjska kultura ni u jednoj razvojnoj fazi ne javlja samostalno, odnosno da su elementi starčevačke kulture bili prisutni u svim razvojnim fazama, čak i do prodiranja crnoglačane, spiralne i trakaste keramike. Prerastanje jedne kulture u drugu, odnosno jedne periferne varijante starčevačke kulture u novu kulturnu pojavu, nije sporno, ali prema analizama Slaviše Perića to se prerastanje nije razvilo u okvirima nove kakanjske kulture, kako je to ranije definisao Benac, nego u butmirsku kulturu. Prema tome, stratum III i IV naselja Obre I, I. faza Okolišta, Arnautovići, Kakanj, Plandište i Tuk predstavljaju prelaznu fazu u procesu formiranja butmirske kulture, koja je definisana terminom protobutmirska faza i obuhvata fazu Protobutmir Ia paralelnu sa Obre I/III i Protobutmir Ib paralelnu sa Obre I/IV (Perić 2012: 25). U relativnohronološkom smislu, protobutmirska faza bi pripadala kasnom srednjem odnosno ranom mlađem neolitu (Pandžić 2014: 53).

Tabela I. Relativnohronološki odnos starčevačko-impresso i butmirske kulture na lokalitetu Obre I

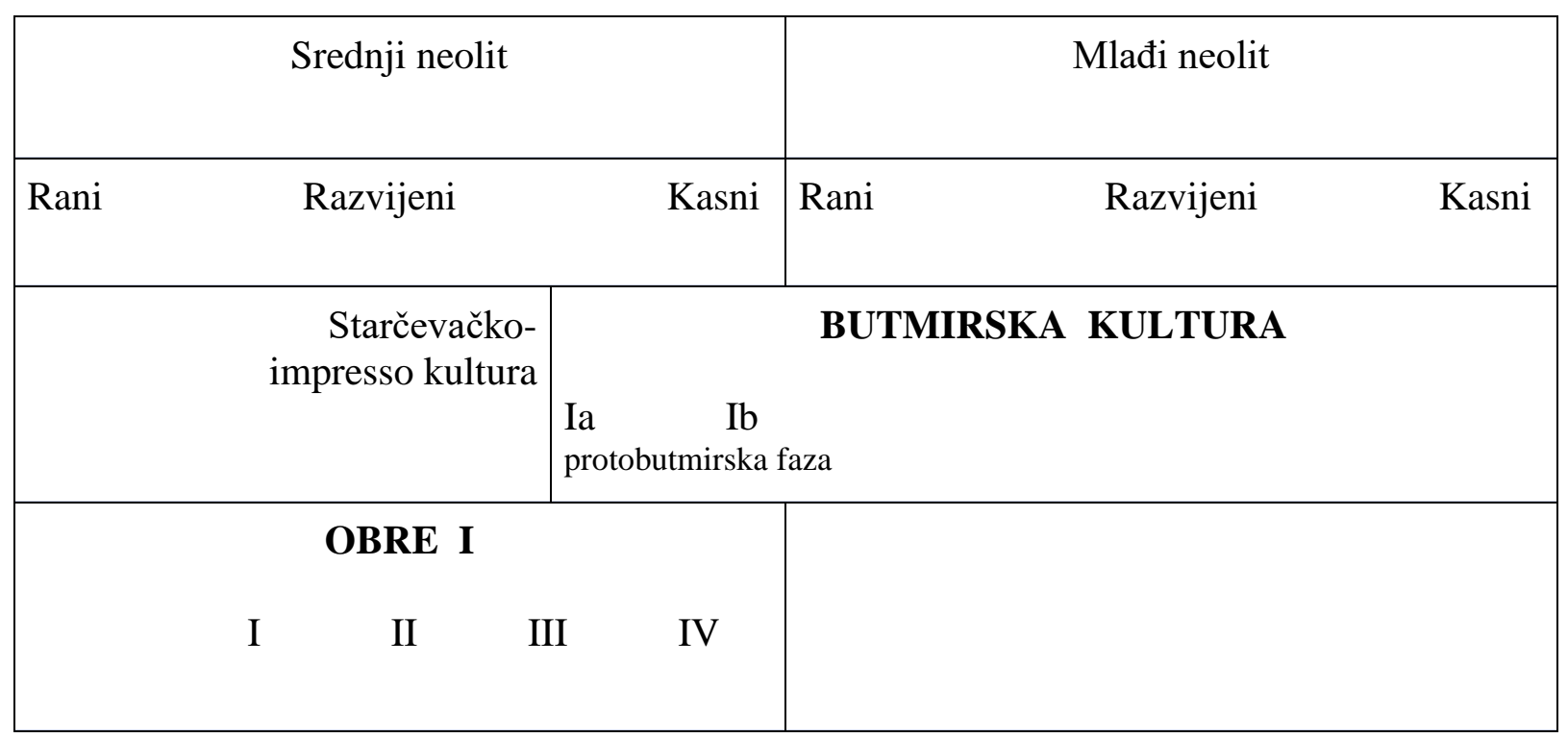




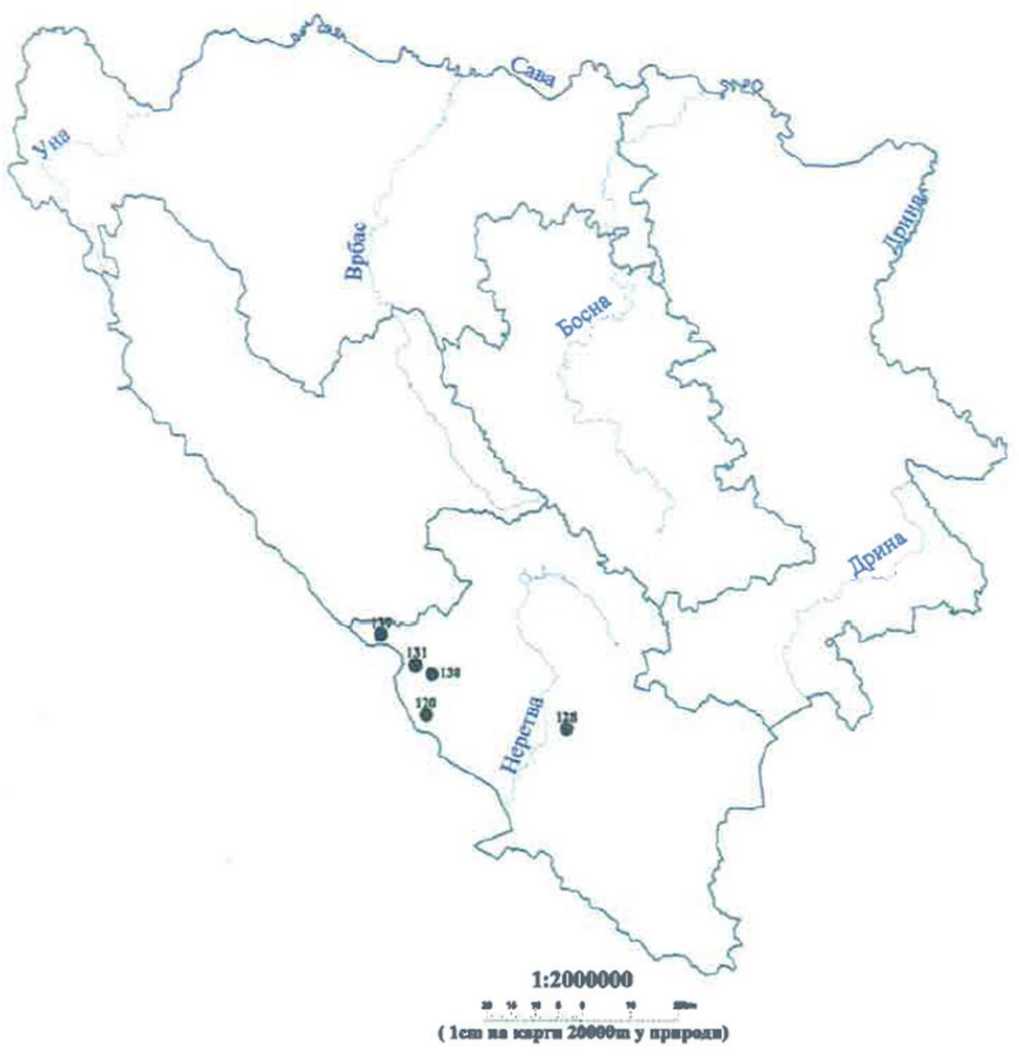

Slika 10. Lokaliteti starijeg neolita na području Bosne i Hercegovine (Pandžić 2014: 153) 


\section{3c Neolit sjeveroistočne Bosne - uticaj starčevačke i vinčanske kulture}

Region sjeveroistočne Bosne karakteriše prelazak brdskog krajolika srednje Bosne preko planine Majevice na jugu, ka ravničarskim predjelima prema sjevernoj granici sa Hrvatskom i Srbijom, odosno rijekama Save na sjeveru i Drine na istoku. Na zapadu se prostire do rijeke Bosne, dok mu južna granica nije omeđena nijednom rijekom, nego je od istočne Bosne odvojena granicama podrinjskog kantona. Najveća administrativna jedinica ovog prostora pripada tuzlanskom kantonu čija je oblast bila naseljena još od srednjeg neolita - nosioci starčevačke kulture tada su se naselili na području Gornje Tuzle, za koju se smatra da je najstarije naselje u Bosni. Pored Tuzle, važno je napomenuti i druga administrativa područja: Brčko distrikt, zatim gradove Bijeljinu, Gradačac, Srebrenik, Gračanicu, Živinice, Banoviće, Lukavac itd., na čijim područjima su pronađeni tragovi života u prahistorijskom periodu. Sjeveroistočna Bosna nije zauzela veliku ulogu u dosadašnjim istraživanjima, posebno kada se uporedi sa centralnom Bosnom i butmirskom kulturom. Zahvaljujući naporima nekoliko arheologa, od kojih posebno vrijedi istaći Milicu Kosorić, Borivoja Čovića i Alojza Benca, može se formirati osnovna slika o ovom prostoru. Upravo zahvaljujući naporima navedenih autora, može se zaključiti da je sjeveroistočna Bosna bila gusto naseljena kasnoneolitskim populacijama, prije svega nosiocima vinčanske kulture a zatim i sopotske oko rijeke Save, a prije njih i nosiocima starčevačke kulture. Naime, sjeveroistočna Bosna dobila je na značaju otkrićem starčevačkih slojeva u Gornjoj Tuzli, na koje se nadovezuju vinčanski slojevi, pa se na taj način starčevački kulturni kompleks proširio dalje prema jugozapadu u odnosu na matični prostor. Nosioci vinčanske kulture su tokom mlađeg neolita naselili prostor ne samo Gornje Tuzle nego i sjeveroistočne Bosne, na taj način osnivajući mnoga naselja od kojih je svega nekoliko sistematskih istraženo.

Lokalitet Gornja Tuzla (o kojem će kasnije biti sprovedena detaljnija analiza) nalazi se na krajnjim obroncima planine Majevice, uz gornji tok riječice Jale, desetak kilometara od današnjeg grada Tuzle u pravcu sjeveroistoka. Danas se većina lokaliteta, čiju je površinu Čović na osnovu površinskih nalaza keramičkih fragmenata procijenio između 12 i 15 ha, nalazi ispod slojeva gusto naseljene ili već poljoprivredno obrađivane površine. Prvi koji je konstatovao postojanje lokaliteta bio je Đuro Basler koji je 1949. godine pronašao jedan grob starijeg željeznog doba. Nedugo zatim, naselje su obišle stručne ekipe predvođene A. Bencom i B. Čovićem, da bi Čović otvorio prvu sondu na ovom lokalitetu godine 1955., s ciljem da se utvrdi da li postoji više grobova iz starijeg željeznog doba. Čović nije imao uspjeha u pronalasku grobova, ali je prilikom kopanja na dubini od približno $2 \mathrm{~m}$ ustanovio da se kulturni sloj, preplavljen crvenkastom grubom keramikom, nastavlja dublje, što je 
uzrokovalo otvaranje nove sonde godine 1956. No, ni ova sonda nije donijela željene rezultate $\mathrm{s}$ obzirom na to da je veliki dio zemljišta zauzimao jedan stari bunar (Čović 1960-61: 80). Tek naredne 1957. godine utvrđen je kompletan kulturni sloj - tada se kopalo sve do zdravice i utvrđeno je da naselje ima slojeve od starčevačke, preko vinčanske pa sve do bronzanodobnih kultura. Najveća otvorena sonda (u blizini škole, označena na mapi bijelim kvadratom) je ona iz 1958. godine, kada se do zdravice došlo tek na dubini od oko $5,50 \mathrm{~m} \cdot{ }^{37}$

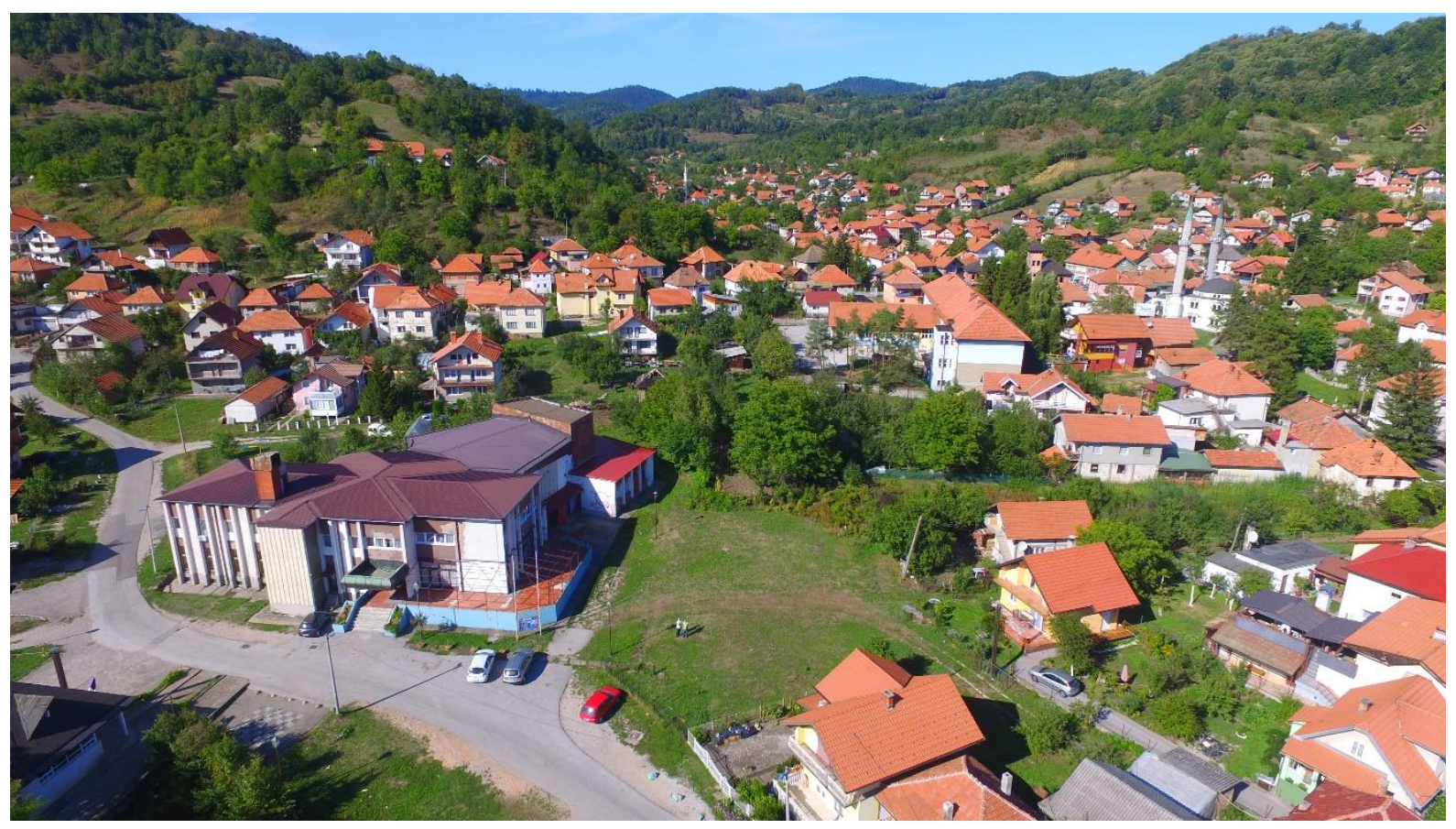

Slika 11. Naselje Gornja Tuzla: pogled na zgradu Društvenog doma i Osnovnu školu (snimio M. Burić)

Pored Gornje Tuzle, potrebno je spomenuti lokalitet u samom centru današnjeg grada Tuzle - Trg Slobode. Početkom izgradnje ovog velikog i značajnog projekta pronađeni su fragmenti keramike, pa su nadležne insitucije izvođaču radova uputile dopis da obustavi građevinske radove. U augustu 2008. godine otvorena je sonda dimenzija 4 x 4 m u centralnom dijelu trga, i u njoj je zabilježen veoma debeli recentni sloj koji se pružao od dubine od 1,20 do 1,40 m. Do zdravice se došlo na dubini od $4 \mathrm{~m}$. Radove je izvodio Mirsad Bakalović, kustos arheologije JU Muzeja Istočne Bosne u Tuzli, u saradnji sa profesorima historije Ademom Šehidićem i Almirom Mušovićem, a lokalitet je obišla i Zilka Kujundžić-Vejzagić, kao predstavnica Zemaljskog muzeja Bosne i Hercegovine. Trenutno postoji svega jedan rad objavljen o ovom lokalitetu (autor mu je profesor historije Almir Mušović) u kojemu se u kratkim crtama navode proces početka radova te nekoliko zaključaka. U radu se navodi kako je na dubini od 3,50 m pronađen dio nastambe, odnosno dio ognjišta i podnice, 37 Recentnih oštećenja sloja skoro da i nije bilo, pa su rezultati iskopavanja sa ove sonde uzeti kao stratigrafska baza
(Sonda II-1958). 
oko i ispod čega se pružao sloj kućnog lijepa. Autor zatim navodi slijedeće: Ono što je posebno važno, jer pomjera granice nastanka ovog neolitskog naselja, jeste otkriće fragmenata keramike (finoglačana i bojena keramika, kao i ostaci drški-tunelaste) koja pripada prelaznom periodu iz kasnog starčeva u ranu vinču (Mušović 2010: 114). Između ostalog, iznesen je veoma bitan zaključak koji je potvrdila Zilka Kujundžić-Vejzagić, a to je da su pronađeni nalazi kasne starčevačke kulture u okviru ovog velikog neolitskog naselja vinčanske kulturne grupe. Međutim, uvidom u materijalne nalaze deponovane u tuzlanski muzej ustanovljeno je da ni jedna kesa nema adekvatnu signaturu, odnosno da se navodi samo godina iskopavanja i lokalitet, pa su navedeni nalazi ostali bez konteksta. Ono što je očigledno nakon pregleda materijala jeste odlika vinčanske kulture sa svim svojim karakteristikama, ali više od toga trenutno nije moguće potvrditi.

Na osnovu Izvještaja o rezultatima zaštitnog arheološkog istraživanja na lokalitetu Trga Slobode, koji je 6. 11. 2008. godine Zavodu za urbanizam Općine Tuzla predao Mirsad Bakalović, kustos

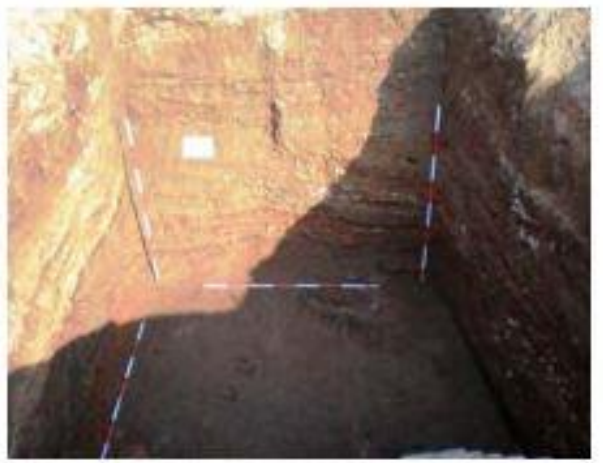

Sonda iskopana u centralnom dijelu Trga slobode, mjesto na kojem se danas nalazi fontana arheologije Muzeja Istočne Bosne u Tuzli, utvrđeno je kako su rekognisciranja građevinskih radova počela u ponedjeljak, 18. 8. 2008. godine i da se dva dana kasnije pristupilo otvaranju sonde. Najveća koncentracija pokretnog materijala nalazila se na zapadnom djelu Trga, ispred stare zgrade Općine Tuzla, a širi se na sjever prema zgradi Privredne komore. Izvještaj potvrđuje navode o pronalasku podnica i ognjišta, i ukazuje na to da je uzeto nekoliko uzoraka gari i lijepa iz ognjišta te kostiju pronađenih u ognjištu, radi buduće radiokarbonse analize do koje prema svemu sudeći nikada nije došlo. Keramika pronađena u ognjištu sonde I, sudeći prema izvještaju, pripada kasnom starčevu, tj. prelaznom periodu između ove dvije neolitske kulturne grupe.

Slika 12. Prikaz profila sonde sa Trga slobode (Mušović 2010: 113)

Ipak, kako je ranije navedeno, nemoguće je pronaći ovaj materijal manje zastupljen u odnosu na mnogobrojni vinčanski, s ozbirom na to da ni jedna kesa nije signirana, a nalazi su izmiješani. Posmatrano sa geografskog aspekta, nije nemoguće da su nosioci starčevačke kulture prodrli južnije u odnosu na Gornju Tuzlu, dolinom rijeke Jale, i osnovali naselje na mjestu na kojem je poznato da postoje naslage rude soli. Ipak, podatke o starčevačkim oblicima keramike treba uzeti sa rezervom dok se navedeni materijal podrobnije ne ispita, ili dok se ne uradi neko novo istraživanje. Tokom 2018. godine, prilikom novih građevinskih radova u neposrednoj blizini Trga Slobode, pronađeni su 
novi nalazi od neolitskog do osmanskog perioda. Nažalost, radovi nisu obustavljeni uprkos dopisima koje su uputili muzej i zavod da se izvrši istraživanje prije dodatnog uništavanja lokaliteta. Ostale su samo fotografije koje su objavili mediji i na kojima se jasno vidi klasična gornjotuzlanska keramika vinčanskog porijekla. Uništeni lokalitet udaljen je svega $20 \mathrm{~m}$ od trga gdje je 2008. godine otvorena sonda i predstavlja veoma veliko područje naseljeno neolitskim stanovnicima. Upitno je da li će se ikada više moći pristupiti značajnijim istraživanjima s obzirom na to da je cjelokupni prostor već gusto izgrađen i naseljen.

Gornja Tuzla nalazi se sa južne strane Majevice, pa je bilo logično pretpostaviti da bi moglo postojati još starčevačkog materijala sa sjeverne strane. Na taj je način pronađen lokalitet Varoš kod Koraja koji predstavlja drugi najznačajniji lokalitet sjeveroistočne Bosne. ${ }^{38}$ Istraživanja su rađena u isto vrijeme kad i u Gornjoj Tuzli, 1957. godine kada je iskopano $65 \mathrm{~m}^{2} \mathrm{u}$ dvije sonde, od kojih je jedna uzeta kao stratigrafska baza a druga kao građevinska. Na osnovu analize materijala Benac je odredio četiri stratuma naselja u Varoši ${ }^{39}$ i stratum V Gornje Tuzle hronološki vezao za najstariji stratum IV na lokalitetu Varoš kod Koraja (Čović 1961: 115). Naselje u Varoši zauzima stratigrafski interval u Gornjoj Tuzli od stratuma V do kraja stratuma II. To naselje od samog početka ima "čisto" vinčanski karakter, ${ }^{40}$ bez dosada pronađene starčevačke tradicije, pa se može pretpostaviti da je naselje u Gornjoj Tuzli u jednom trenutku ostalo izolovano i u potpunosti prepušteno novim uticajima koji su dolazili sa istoka.

\footnotetext{
${ }^{38}$ Lokalitet je u odnosu na Gornju Tuzlu udaljeno oko $20 \mathrm{~km}$ sjeveroistočno i nalazi se s druge strane planine Majevice. Iskopavanja su vršena paralelno u isto vrijeme kao i u Tuzli, pod rukovodstvom A. Benca.

${ }^{39}$ Stratum I: 0-0,90 m, stratum II: 0,90-1,90 m, međustratum II/III: 1,90-2,10 m, stratum III: 2,10-2,80 m, stratum IV: 2,80-4,10 m (Benac 1960-61: 49).

${ }^{40}$ U Varoši ne postoji nikakav stratum sa slikanom keramikom, pa je prema tome naselje u Gornjoj Tuzli starije za čitav jedan stratum. Kulturni razvoj se od samog početka zasniva na crno i sivo poliranoj keramici, pa je prema tome od početka vezan za vinčansku kulturu (Benac 1960-61: 58).
} 


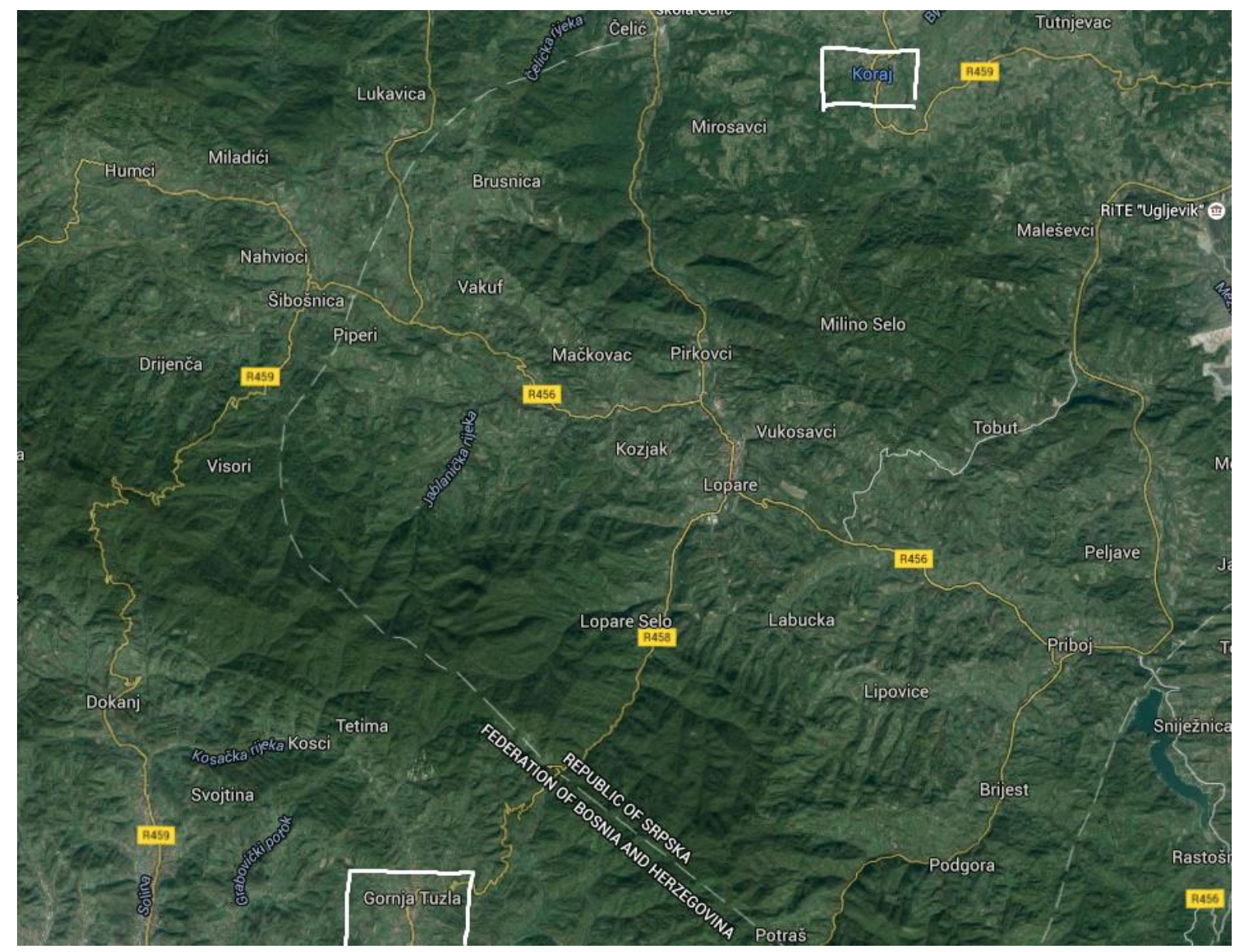

Slika 13. Geografska lokacija naselja Varoš kod Koraja u odnosu na Gornju Tuzlu (Google maps, 2015)

U stratumu IV Gornje Tuzle primjećuje se iščezavanje starčevačkih elemenata u korist vinčanskih koji sada već preovladavaju, ali nije prestala upotreba lokalne domaće crvenkaste grube keramike (kakva se i danas vidi na površini lokaliteta), rađene sa velikom primjesom krečnog pijeska, koja utvrđuje kontinuitet i vezu sa starijim slojevima. Prema tome, stratum IV naselja u Gornjoj Tuzli bi na osnovu analize materijala odgovarao sloju III i prelaznom sloju III/II naselja Varoš kod Koraja. Prema Bencu, ti stratumi u Varoši hronološki bi odgovarali mlađoj vinčansko-tordoškoj fazi (Benac 1960-61: 120), što bi stratum IV hronološki smjestilo Gornje Tuzle na kraj vinčansko-tordoške faze, ${ }^{41}$ o čemu govori Milutin Garašanin u svom radu o mlađem neolitu Bosne i Srbije (Garašanin 1954: 9).

Keramiku sloja IV Varoši karakterisale su tamne i sive mrlje na grubim bikoničnim i koničnim sudovima, dok su od fine keramike zastupljene vaze na nozi i bikonične zdjele ukrašene kanelurama na kojima nisu zapažene trakaste drške, već drške u obliku životinjske glave. Primjetna su dva načina

${ }^{41}$ Prema Garašaninu, Vinča-Tordoš II (D. Garašanin 1954: 108), a prema Milojčiću, Vinča B2 (Milojčić 1949: 72). 
ukrašavanja, tamne ili svijetle mrlje uglavnom nanesene pravilno te tamni ton preko cijele površine zdjele (Benac 1960-61: 49). ${ }^{42}$ Što se tiče građevinskog dijela, u zdravici sonde II bila je ukopana jedna veća jama nepravilnog oblika ali mekanog unutrašnjeg sadržaja, iznad koje je u profilu detektovano šest građevinskih faza odnosno šest linija kompaktnog lijepa i gareži. Najstariji ostaci jedne građevine (podnica kuće) pronađeni su u lijepu na dubini od 2,70-3,30 m, jer dubina varira prema mjestu u sondi koje je najdublje propalo na sredini direktno iznad jame (Benac 1958: 7). ${ }^{43}$ Druga podnica otkrivena je na dubini od 2,20-2,80 m, što je opet zavisilo od mjesta u sondi. ${ }^{44}$ Ona bi pripadala III. stratumu sonde I u kojem su znatno rjeđi nalazi sa ukrasima tamnih mrlja, što se razlikuje od prethodnog sloja. Najkarakterističniji oblik grube keramike predstavlja posuda sa unutra uvučenim talasastim obodom formiranim vertikalnim pritiskom prsta, sa trakastim i cilindričnim drškama. Fina keramika zastupljena je vazama na nozi i plitkim amforicama ukrašenim kanelurnim motivima, a drške su i dalje karakteristične, u obliku životinjskih glava (Benac 1960-61: 53).

Pri dubini od 1,90 m Benac je naišao na tri rupe od stubova koje se rasprostiru u pravoj liniji kroz sondu i za koje je pretpostavio da ocrtavaju liniju kućnog zida, čime je ustanovljeno postojanje pravougaonih kuća na površini zemlje, kao i sistem izgradnje kuća sa stubovima. Ova građevinska faza odgovarala bi stratumu II u kojem dolazi do novog razvoja i kada je u pitanju keramika. Ukrasi mrljama se gube, dominantna je plastična dekoracija modelovana prstom, a posebnu karakteristiku čine amfore sa zaobljenim trbuhom ukrašene kanelurama i s trakastim drškama. Od fine keramike, vaze na nozi imaju isključivo šuplje noge, a najviše su zastupljene zdjele sa cilindričnim vratom i zdjele sa vani izvijenim vratom koje ranije nisu bili u upotrebi. Tehnika kaneliranja i dalje ostaje dominantni oblik ornamentike, dok poseban vid ukrasa čine stilizovane životinjske glave koje služe i kao drška (Benac 1960-61: 56). Značajan nalaz svakako predstavlja četvrtasto ognjište pronađeno na dubini od 1,40 m, gdje se nalazila jama sa dosta naslaga luga koji je u nju odlagan. Neposredno iznad ognjišta pronađena je druga podnica, dosta čvršćeg i kompaktnijeg sastava, debljine $25-30 \mathrm{~cm}$ (Benac 1958: 11). Iznad nje pronađena je još jedna čvrsta podnica sa čistim profilom, debljine 40-55 $\mathrm{cm}$, što je čini najdebljom podnicom u naselju. Ona bi pripadala najmlađem stratumu I u kojem dolazi do novih keramografskih promjena: nestaju šiljate noge i zašiljena dna kod grube keramike, glavna karakteristika postaju neprobušene drške. Kod fine keramike i dalje dominiraju vaze na nogama i zdjele sa cilindričnim vratom. U potpunosti su nestale zdjele sa izvijenim vratom, dok

\footnotetext{
42 Ovakvu karakterističnu keramiku Benac je nazvao "šarena keramika".

43 Debljina gareži u prosjeku je iznosila oko $0,20 \mathrm{~cm}$.

${ }^{44}$ Pronađene su dvije ljudske statuete, za koje je Benac bio uvjeren da su usko povezane sa građevinskom djelatnošću na pronađenim dubinama. Jedna je pronađena ispod podnice, a druga u uglu sonde. Ovaj nalaz je predstavljao jedine ljudske figure dotad pronađene, sve do 2007./2009 godine kada je u Gornjoj Tuzli pronađena jedna ljudska figurina koja nikada nije objavljena.
} 
zdjele sa uvučenim obodom predstavljaju osnovno obilježje stratuma, zajedno sa horizontalnim trakastim drškama. Na osnovu analize keramike Varoši kod Koraja ustanovljeno je da ona u potpunosti pripada vinčanskoj kulturi, o čemu svjedoče i građevinski nalazi i sistem izgradnje kuća. Benac ističe važnost ovog lokaliteta i smatra da bi ono bilo idealno za dalja ispitivanja o neolitskim kućama, zahvaljujući dovoljno debelom kulturnom sloju i sačuvanim nalazima, te navodi kako bi Zavičajni muzej trebao poduzeti mjere da se jedno ovakvo istraživanje sprovede (Benac 1958: 19). Varoš, dakle, predstavlja naselje posve vinčanskog karaktera, mlađe od Gornje Tuzle za jedan sloj, odnosno za sloj slikane keramike determinisane u najdubljim stratumima Gornje Tuzle. Od samog početka Varoši kulturni razvoj se zasniva na crnoj i sivo poliranoj keramici, dok se u Gornjoj Tuzli dosta duže zadržao starčevački uticaj. Mlađi stratumi vinčanske kulture u Gornjoj Tuzli paralelno teku sa onima iz Varoši, odnosno slojevi Varoš IV-I su jednaki gornjotuzlanskim slojevima V-II.

Tabela 2. Stratigrafski interval naselja u Gornjoj Tuzli i Varoši kod Koraja

\begin{tabular}{|c|c|c|}
\hline \multicolumn{2}{|c|}{ Gornja Tuzla } & \\
\hline Kultura & VIb aroš kod Koraja \\
\hline starčevačka & VIa & IV \\
\hline starčevačka & V & III \\
\hline vinčanska & IV II \\
\hline vinčanska & III & I \\
\hline vinčanska & II & \\
\hline vinčanska & I & \\
\hline rani eneolit & & \\
\hline
\end{tabular}

Drugačija situacija je u Donjoj Tuzli odnosno današnjem gradu Tuzli, gdje se za pronađene tragovi smatra da su ostaci sojeničkog naselja (Puš 1957: 85) koje je mlađe od onoga iz Gornje Tuzle, pa i Varoši kod Koraja. Naselje leži na manjem uzvišenju sa desne strane Jale (Šarena džamija) i označava prirodan tok naseljavanja niz dolinu rijeke Jale, preko mjesta Simin Hana preko kojega je, 
kako se pretpostavlja (s obzirom na nalaz kamene sjekire, godine 1967. ${ }^{45}$ ), vodila putna komunikacija od Gornje Tuzle ka Tuzli, gdje su zabilježeni tragovi slanih izvora. Nakon podizanja sojenica $^{46}$ bilo je lakše eksploatisati slane izvore s obzirom na močvarne predjele koji su se formirali pod uticajem vode i slanih izvora (Milić, Kulenović, Panjević 1985: 8-11). Pronađeni materijal predstavlja slučajne nalaze iskopane prilikom građevinskih radova i ujedno je prvi pokušaj kulturnog rekognosciranja naselja. ${ }^{47}$ Kopalo se do dubine od 3,72 m, tj. do dubine dovoljne za temelj zgrade koja se na tom prostoru gradila, ali se do zdravice nije došlo (Puš 1957: 86). Pronađeni su u znatnim količinama fragmenti grubih posuda sa uvučenim valovitim obodom, što je uzeto kao indikacija početka života naselja prilikom čega je povučena paralela sa stratumom III Varoši i te stratumom IV Gornje Tuzle (Benac 1960-61: 59). Naselje pripada vinčanskom kulturnom kompleksu, ali kao što je navedeno - nikada nije istraženo do kraja, pa se ne zna da li ima dubljih slojeva.

Godine 1955., prilikom rekognisciranja terena sjeveroistočne Bosne, otkrivena su još dva prahistorijska lokaliteta: gradina u zaseoku Grbači kod Gornje Slatine i Gradić u selu Matiću kod Tolise. Inicijalnim istraživanjem zaključeno je da su oba naselja po položaju i površinskim nalazima veoma slična te da vjerovatno predstavljaju jednu kulturnu cjelinu (Benac 1957: 209). Dvije godine kasnije izvršena su sistematska iskopavanja koja je predvodio Benac, na osnovu čijeg se istraživanja došlo do važnih spoznaja o ovim lokalitetima. Gradina u Grbači čini cjelinu sa Gornjom Slatinom koja pripada opštini Bosanski Šamac i nalazi se na uzvišenju koje se ističe u odnosu na okolne ravnice. Otvorena je jedna sonda dimenzija 5 x $5 \mathrm{~m} .{ }^{48}$ Recentni sloj je bio relativno plitak, svega 15ak cm, da bi se ispod toga ušlo u kulturni sloj u kojem su se do dubine od 3,20 m javile dvije jame, jedna na dubini od 0,60-0,80 m u kojoj je pronađen lijep sa otiscima kolja, a druga na dubini od 2,60-3,20 m gdje se pojavila ilovača, pa je pretpostavljeno da se iz nje vadila žućkasta ilovasta zemlja (Benac 1960-61: 40). Kulturni sloj je debeo 1,80 m i podijeljen je na dva stratuma sa granicom na oko $0,80 \mathrm{~m}$. Za donji stratum karakteristične su grube konične noge, kakve se masovno pojavljuju u Gornjoj Tuzli, ali i u Varoši kod Koraja, i predstavljaju bitnu karakteristiku za određene periode neolita sjeveroistočne Bosne. Pronađeno je dosta trakastih drški smještenih uglavnom uz

\footnotetext{
45 Dokumentacija arheološkog odjeljenja Muzeja Istočne Bosne u Tuzli.

46 Navod da se radi o sojenicama je hipotetičke vrijednosti (Marijanović 1988: 105).

47 Prvi nalaz neolitskog perioda u Tuzli poznat je od 1903. godine i pronađen je prilikom radova na Trgu Slobode. Stručnu analizu načinio je Vejsil Čurčić, koji je ustanovio da je na području Tuzle postojalo neolitsko naselje čiji su stanovnici pored tradicionalnih privrednih djelatnosti vjerovatno koristili i izvore slane vode (Čurčić 1908: 80-81).

48 Jedan od mještana je tvrdio kako je pronalazio fragmente keramike na dubini do $8 \mathrm{~m}$ prilikom kopanja bunara, pa je Benac pomislio da bi moglo biti riječi o veoma dubokom kulturnom sloju i iz tog je razloga krenuo sa kopanjem sonde većih dimenzija. No, ispostavilo se da je kulturni sloj bio mnogo plići (Benac 1960-61: 40).
} 
obod, horizontalnog smjera i sa nešto većim pregibom na sredini. ${ }^{49}$ Rijetka je fina glačana keramika, posebno crna. Zapažena su samo dva poveća fragmenta zdjela sa izvijenim vratom i okomitim kanelurama, tamnosive površine. Češći su nalazi poluglačanih oblika, crvenosmeđe i tamnosmeđe boje. Benac je na osnovu nalaza koničnih nogu pretpostavio da stratum II Gradine hronološki odgovara stratumu II Varoši, gdje takve noge predstavljaju izrazitu osobinu na toj dubini (Benac 1960-61: 42). Mlađi sloj karakteriše potpuni gubitak grubih koničnih nogu, dok su trakaste horizontalne drške i dalje u upotrebi, ali se javljaju i drške sa plastičnim ispupčenjima, što je uzeto kao paralela sa stratumom I Varoši. Kanelirani oranamenti su u izumiranju, dok su pojačani nalazi urezane ornamentike ili žigosanih kružića na fragmentima crne glačane keramike. Keramika iz Grbače dosta je grublja u odnosu na onu iz Varoši, što Benac objašnjava perifernom lokacijom naselja u odnosu na centar Vinče i navodi da je ta gradina krajnje zapadno nalazište u sjeveroistočnoj Bosni (Benac 1960-61: 43).

Gradić u Matiću, lokalitet okruglog tela koji se nalazi na uzvišenju okruženom barovitim pijeskom, pripada opštini Orašje. Otvorena je sonda dimenzija 4 x 4 m s tankim recentnim slojem debljine svega $10 \mathrm{~cm}$. Do dubine od $90 \mathrm{~cm}$ primijećena je velika količina lijepa, što bi ukazivalo na intenzivne građevinske djelatnosti. Na dubini od $90 \mathrm{~cm}$ pronađen je ljudski kostur koji je pripadao muškarcu starijih godina, položen na leđa, sa rukama prekrštenim na prsima, orijentacije istokzapad. Nekoliko centimetara iznad kostura pronađeni su fragmenti posuda rađenih na lončarskom kolu, pa se kostur datirao u kasnoantički period. Na dubini od 1,40 m došlo se do jame najvećeg promjera 1,50 m, ukopane u zdravicu, koja je dopirala do dubine od 2,50 $\mathrm{m}$ i unutar koje su se nalazili komadići fine glačane keramike i nešto veći komadi lijepa. Benac je pretpostavio da je i ova jama korištena za vađenje ilovače i da je služila kao jama za otpatke ili kao ostava (Benac 1960-61: 44). Definisana su dva kulturna stratuma, sa granicom na dubini od $0,90 \mathrm{~m}$. Stariji sloj karakterišu bikonične grube visoke posude sa izvučenim gornjim obodom. Fina keramika je daleko bolje polirana od one u Grbači, ističu se vaze na nozi ${ }^{50}$ i bikonične zdjele sa cilindričnim vratom. Nisu pronađene posude sa drškama, već su se kao drške uglavnom koristila manje naglašena plastična ispupčenja. Osnovni motiv ukrašavanja izveden je tehnikom kaneliranja - okomiti i kanelirani krugovi sa okcem; taj se motiv pojavljuje i u stratumu II Varoši, čime je stariji sloj Gradića horizontalno povezan sa Varoši kod Koraja II. Keramika mlađeg stratuma je relativno siromašna u odnosu na stariji, nedostaje fino glačana roba koja je karakterisala stratum II. Uglavnom se pronalazi

\footnotetext{
49 Za ovaj lokalitet karakteristične su i posude grublje fakture (mrke i hrapave) koje na obodu imaju kljun za izlivanje, kakve su pronađene i u Gornjoj Tuzli.

50 Noge su visoke, valjkaste i pune, sa proširenom bazom, te šuplje, s vanjskom površinom ukrašenom horizontalnim kanelurama.
} 
poluglačana keramika hrapave površine tamnosive i crvenkasto-smeđe boje. I dalje se koriste vaze na nozi, ali noga je sada šuplja sa proširenom bazom. Javlja se novi oblik grubih posuda sa šiljastim dnom koje ovaj sloj Gradića vezuju sa stratumom II u Grbači, a samim time i Varoši, iz čega se vidi da je Gradić nešto stariji od Grbače. Pronađene su trakaste drške na vazama, za razliku od donjeg sloja, dok se tehnika kaneliranja zadržala ali je puno rjeđa i svedena je na nešto šire kanelure (Benac 1960-61: 46).

Nalazište Lug nalazi se 3,5 km južnije od Goražda, na samom rubu platoa koji se pruža na desnoj obali Drine. Nažalost, lokalitet je devastiran prilikom radova mašina. Na centralnom dijelu moglo se zateći debelih komada lijepa koji vjerovatno pripadaju nekoj čvršćoj podnoj konstrukciji. Prilikom naknadnog pregleda terena Benac i Basler su odredili kulturološku pripadonost lokaliteta. Gruba keramika je pretežno crvenkaste i smeđe površine, dobro pečena i sa mnogo sitnog bijelog pijeska. Najkarakerističniji oblik fine keramike predstavlja bikonična zdjela, izrađena od dobro prečišćene zemlje tamnosive ili crvene površine, na kojoj glačanje nije doseglo veći kvalitet. Drške su uglavnom tunelastog oblika, a jedna od karakteristika ovog lokaliteta su drške u obliku ptičije glave, ustanovljene u dva primjerka. Uočene su dvije vrste ukrasa: kanelure i duguljasta ispupčenja. Kako su jednu pljosnatu statuetu pronašli radnici, ne može se reći nešto više o njenom kontekstu u sondi. Prema osnovnim karakteristikama tamnosive ili crne keramike, osrednje glačane i sa gotovo isključivo kaneliranom ornamentikom, Benac je zaključio da Lug pripada vinčanskoj kultunoj grupi (Benac 1959: 59). ${ }^{51}$ Hronološka usporedba sa Varoši rađena je na osnovu plastičnih ispupčenja koja se nalaze u prelaznom stratumu III/II te je uporedo s tim i okvirno determinisana pripadnost. Susjedni lokalitet Popov do, smješten iznad Hranjenskog potoka na lijevoj strani Drine sjeverozapadno od Goražda, također je znatno uništen okolnim radovima. Ponovo su Benac i Basler pokušali da odrede neku stratigrafsku sliku i zaključili da se kulturni sloj nalazi na dubini od 0,601,70 m, nakon čega slijedi ilovasta zdravica. Sudeći prema nešto većim pronađenim fragmentima, keramika se razlikovala od one u Lugu. Grube posude su uglavnom svjetlosive površine, dok je fina keramika crnosmeđe boje sa crvenkastim preljevima pri obodu, što zajedno sa oblicima vaza i ornamentalnim motivima više podsjeća na keramiku iz Lisičića kod Konjica (Benac 1959: 62).

Gradac u selu Batkovićima kod Bijeljine još je jedan lokalitet sjeveroistočne Bosne koji pripada vinčanskom kulturnom kompleksu, a otkriven je 1966. godine prilikom izgradnje silosa, kada je znatan dio lokaliteta i uništen. Iste godine muzej Tuzla je poslao stručnu ekipu da se utvrdi o kakvim

\footnotetext{
${ }^{51}$ Geografski posmatrano, Lug je najjužnije locirani lokalitet u odnosu na neolitske lokalitet sjeveroistočne Bosne, odnosno najjužniji lokalitet vinčanske kulture u Bosni. Keramika je znatno siromašnija, ali je zadržala osnovne zajedničke elemente, oblike zdjela, vaze na koničnoj šupljoj nozi, kanelirani ornamenti na gornjem konusu zdjela i osnovni ton površine.
} 
nalazima je riječ. Otvorene su četiri sonde, dvije veličine $5 \times 5 \mathrm{~m}$, treća 5 x 3 m i četvrta 4 × $3 \mathrm{~m}$. Ispitana je površina od $72 \mathrm{~m}^{2}$ i ustanovljen je kulturni sloj čija dubina varira od 1,70 do 1,90 m. Izdvojene su dvije građevinske faze čija je međusobna granica ustanovljena na dubini od 1,10-1,20 m i u kojima je detektovano dosta kućnog lijepa uglavnom crveno-žute boje, na kojem se vide otisci pruća. Pronađeni su ostaci izgorjelih stubova, zatim podnice i dijelovi porušene peći oko koje su konstatovani jaki tragovi gorenja te ostaci puževa, školjki, životinjskih kostiju i troske (Kosorić 1967: 22). Gruba keramika sadrži sitnije i krupnije tragove pijeska uglavnom tamne i sive boje, a najviše su zastupljene posude sa ravnim obodom i cilindričnim vratom. Dna posuda su ravna, a konusne noge sudova karakteristične su za neolit sjeveroistočne Bosne. Drške su trakaste i tunelaste, a ima i fragmenata plastičnih drški jezičastog i bradavičastog oblika. Ornamenti su uglavnom izvođeni utiskivanjem prsta u svježu glinu. Fina keramika rađena je od prečišćene zemlje sa sitnim zrncima pijeska, tankih je zidova tamne i sive boje i uglavnom uglačane površine. Zastupljeni su konusni i bikonusni obilici među kojima se ističe plitka zdjela-pehar na šupljoj zvonastoj nozi. Drške su uglavnom plastične, a ornamentika je rađena tehnikom kanelisanja; na jednom je primjerku prisutan i motiv spirale (Kosorić 1967: 23).

Neolitsko naselje Dobrovac nalazi se u blizini Čelića, a njegovo postojanje konstatovano je 1963. godine prilikom rekognosciranja terena kada je pronađeno dosta keramičkih nalaza i ostataka kućnog lijepa. Istražena je površina od $51 \mathrm{~m}^{2} \mathrm{u}$ tri sonde, a do zdravice se došlo na dubini od 1,30-1,40 m. Pronađeni keramički materijal ne pokazuje bogatstvo u ornamentalnim motivima, kao ni veliku raznovrsnost oblika. Najčešći sudovi su koničnog i bikoničnog oblika, sa ravnim obodom i cilindričnim vratom, ukrašeni kanelurama ili plastičnim otiscima prsta ili nokta. Prema svemu navedenom lokalitet pripada vinčanskoj kulturi, konkretnije II. i I. stratumu Varoši kod Koraja sa kojim pronađeni materijal ima najveće sličnosti (Kosorić 1970: 12).

Među značajnijim i sistematski istraženim lokalitetima sjeveroistočne Bosne je i naselje Korića han, koje se nalazi južno od Gračanice u dolini rijeke Spreče i jedini je neolitski lokalitet sjeveroistočne Bosne koji je proglašen nacionalnim spomenikom 2003. godine. ${ }^{52}$ Postojanje naselja konstatovano je 1971. godine slučajnim nalazima otkrivenim prilikom kopanja temelja, kada je istražena manja površina od 7,2 $\mathrm{m}^{2}$ (Kosorić 1972: 5). Nedugo zatim otvoreno je još sedam sondi i istražena je znatno veća površina ovog lokaliteta. Debljina kulturnog sloja varira u različitim sondama od 1,80

\footnotetext{
52 Dana 13. decembra 2002. godine Opština Gračanica je Komisiji podnijela Prijedlog za proglašenje nepokretnog dobra - Neolitsko naselje Korića han nacionalnim spomenikom Bosne i Hercegovine. Prijedlog je zaprimljen pod brojem 01420/02. U skladu sa odredbama Zakona, a na osnovu člana V, stav 4. Aneksa 8. i člana 35. Poslovnika o radu Komisije za očuvanje nacionalnih spomenika, komisija je pristupila sprovođenju postupka za donošenje konačne odluke za proglašenje dobra nacionalnim spomenikom (Službeni glasnik BiH 2003: 32).
} 
do 2,70 m. Izdvojena su dva kulturna perioda i četiri građevinske faze, od čega starijem periodu pripadaju slojevi od zdravice do oko 1,40 $\mathrm{m}$ i dvije građevinske, a mlađem slojevi iznad te dubine pa do humusa koji je debljine svega $0,10 \mathrm{~m}$. Starijem periodu života pripadaju tragovi od stubova, kućni lijep, dijelovi poda, ostaci ugljenisanog drveta, dijelovi ognjišta te jama polukružnog oblika u kojoj je pronađeno gareži, keramike i životinjskih kostiju. Keramika je uglavnom grube fakture. Javljaju se velike i grube posude sa dosta zrnaca pijeska, koničnog, bikoničnog i loptastog oblika, sa ravnim donjim dijelom, ravnog ili uvučenog talasastog oboda i cilindričnog vrata. Drške su trakastog, tunelastog i plastičnog tipa. Zastupljeni su oblici koničnih, šupljih i punih nogu, te masivnih koničnih nogu sa proširenom bazom, dok je ukrašavanje uglavnom rađeno plastičnim trakama, urezivanjem i kaneliranjem (Kosorić 1980: 105). Navedene karakteristike starije faze Korića hana imaju hronološke dodire sa stratumom III Varoši kod Koraja te stratumom IV Gornje Tuzle. Mlađem periodu naselja pripadaju građevinski ostaci: osnova pravougaone kuće, dosta obrušenog kompaktnog lijepa crvene boje sa otiscima pruća, ostaci ognjišta pored kojeg je pronađen i kameni žrvanj, te ostaci uništene peći na dubini od $0,35 \mathrm{~m}$. Osnovna karakteristika posuda je potpuna odsutnost sudova sa uvučenim talasastim obodom odnosno veća upotreba sudova sa razgrnutim obodom i cilindričnim vratom, kao i plitke zdjele sa kratkim vratom i uvučenim obodom. Drške su trakaste i tunelaste, a u ornamentici se javljaju i motivi zareza na obodu i ramenu suda, kao i motivi ispupčenja i udubljenja te širokih kanelura (Kosorić 1980: 106). Mlađa faza Korića hana pokazuje sličnosti sa najmlađim stratumom u Varoši, kao i u Matiću. Naselje Korića han prema tome u potpunosti pripada vinčanskoj kulturnoj grupaciji sjeveroistočne Bosne, a svojim položajem u blizini rijeke i plodnim tlom pružalo je povoljne uslove za život. ${ }^{53}$

Pored navedenih i donekle istraženih neolitskih naselja sjeveroistočne Bosne, vrijedi istaći još nekoliko manje značajnih odnosno slabije istraženih lokaliteta o kojima se u dokumentaciji Muzeja Istočne Bosne u Tuzli nalaze određene informacije. Lokalitet Šarnapo, selo Glavičice kod Bijeljine, nalazi se na visokoj riječnoj terasi na lijevoj obali Drine. Probno sondažno istraživanje je 1975. godine izvršila Milica Kosorić i na nekim je mjestima zabilježen kulturni sloj debljine oko $2 \mathrm{~m}$. Na pronađenom materijalu uočene su karakteristike neolitskog perioda. Krušik u selu Kakmužu kod Gračanice pripada naseljima koja se nalaze u sprečanskoj dolini. Za njega se na osnovu sondažnih rekognisciranja pretpostavlja da pripada neolitskom periodu; uslijed poplava dobrim je dijelom uništeno. Krčevine-Lednjici u selu Trnovicama kod Zvornika nalazi se na uzvišenoj terasi nedaleko od korita rijeke Drine. Godine 1976. rađeno je sondažno istraživanje na osnovu kojeg se ustanovilo

\footnotetext{
53 Zabilježeno je i nekoliko nalaza koji, kako Kosorić navodi, podsjećaju na eneolitske kulture, ali su najplići slojevi naselja u potpunosti uništeni poljoprivrednim radovima (Kosorić 1980: 107).
} 
da je riječ o naselju iz neolitskog perioda. Obrtnjaci, selo Šetići kod Zvornika, također je istraživano 1976. godine i utvrđena je neolitska pripadnost naselja koje ima oblik brežuljka i na kojem su pronađene kamene sjekire jezičastog tipa, kao i kremeni materijal (Bakalović 2017: 92). Lokalitet Bašće, ulica Dardagani u Zvorniku, nalazi se u neposrednoj blizini antičkog kamenoloma, lociran je na lijevoj strani puta Sapna-Zvornik. Na lokalitetu su pronađeni fragmenti keramike, kremeni nožići, nukleus i fragment kamenog žrvnja; nalazi pripadaju vinčanskoj kulturi kasnog neolita. ${ }^{54}$ Lokalitet Dvorišta, na rijeci Drinjači kod Zvornika, nalazi se na lijevoj obali rijeke Drine oko 500 m od ušća Drinjače u Drinu. Kosorić je ondje 1989. godine izvršila probno iskopavanje i svrstala materijal među vinčanske nalaze. ${ }^{55}$ Godinu ranije, 1988. Kosorić je vršila probno istraživanje na brdu Kosici, Hajdarevići kod Zvornika, gdje je pronašla materijal koji je klasificirala kao neolitski vinčanski te mlađi eneolitski i bronzanodobni (Elaborat 1991: 16). Na putu Zvornik-Tuzla Kosorić je površinskim rekognisciranjem terena Suvat kod Karakaja pronašla i nekoliko fragmenata keramike i ulomke lijepa neolitske pripadnosti. Lokalitet Brdo u selu Laništu kod Brčkog ustanovljen je putem rekognisciranja terena 1976. godine, i na osnovu površinskih fragmenata utvrdilo se da ima neolitske i mlađe eneolitske keramike, ali sistematska istraživanja nikada nisu urađena. Kulište u selu Boderištu kod Brčkog ima istu situaciju kao i na lokalitetu Brdo s obzirom na to da nikada nisu izvršena sistematska iskopavanja, ali je površinskim nalazima utvrđeno da keramika pripada neolitskom periodu (dokumentacija Arheološkog Muzeja Istočne Bosne u Tuzli). Identična situacija važi i za lokalitete Kamenik u selu Donjim Vukšićima kod Brčkog, Barice u selu Dubravama kod Brčkog, Ljeskovac u selu Poljacima kod Brčkog, Crkvište u selu Vranoševićima kod Bratunca, Hriđe u selu Mihaljevićima kod Bratunca, Sava u selu Aćimovićima kod Bijeljine, Savića njive u selu Dvorovima kod Bijeljine te Čolakovača u selu Golom Brdu kod Bijeljine.

Jedno od najosjetljivijih pitanja prahistorijske arheologije jeste problem migracija $\mathrm{i}$ autohtonosti određenih kultura. Veoma je teško naći rješenje za ovaj problem, pa se on ne može generalizirati na sva naselja i kulture, nego je potrebno odvojeno gledati na pojedine lokalitete i pokušati odgonentnuti kako je zapravo došlo do formiranja naselja. Uglavnom se koristi teorija migracija određenih kultura koje su se iz vlastitih razloga odlučile na naseljavanje novih, nepoznatih prostora. ${ }^{56}$ Zahvaljujući datiranju s pomoću radiometrijskih metoda pokazalo se kako se neolitik širio od jugoistoka prema sjeverozapadu u tzv. valovima napretka kroz tri tisuće godina (Težak-

\footnotetext{
54 Broj A-3, kategorizacija III (Elaborat 1991: 12).

55 Broj A-7, kategorizacija III (Elaborat 1991: 13).

56 Kod balkansko-anadolskog kompleksa mlađeg neolita ispunjeni su svi metodološki uslovi za postojanje migracije: uska povezanost kulturnih grupa koje ga sačinjavaju, mogućnost geografskog povezivanja i hronološki momenat, ali bitna je i činjenica da ovaj kompleks svugdje zamjenjuje kulturu starijeg neolita (Garašanin 1954: 32).
} 
Gregl 2014: 9). Širenje neolita nije, dakle, bilo podjednako i ravnomjerno, nego je zavisilo od mnogih faktora te je od mjesta do mjesta išlo sporije, odnosno brže. Pretpostavlja se da Jugoistočna Evropa predstavlja zapadni rubni prostor bliskoistočne kulture zemljoradnika, modernim terminom rečeno kolonizovani prostor, što potvrđuju najprije zajedničke tradicije u keramičkim stilovima. ${ }^{57}$ Starčevački kulturni kompleks (Starčevo-Körös-Criş) rasprostire se na većem dijelu Balkana, ${ }^{58}$ a odlikuju ga dominacija grube keramike, ${ }^{59}$ rijetka pojava slikanog ukrasa, barbotin ukras te jednoslojna i kratkotrajna naselja. Posmatrajući periferne dijelove starčevačke kulture, među kojima je i Bosna, primjećuje se tendencija miješanja Starčeva sa ranijim obližnjim srednjeneolitskim kulturama. ${ }^{60}$ Što se tiče neolita Bosne i Hercegovine, ${ }^{61}$ dosad su poznata svega dva lokaliteta koja imaju slojeve Starčeva - Gornja Tuzla i Obre I, ${ }^{62}$ dok je u Slavoniji između Dunava, Save i Drave dosada otkriveno oko 120 naselja starčevačke kulture (Minichreiter 2010: 15). Sam položaj naselja u Gornjoj Tuzli bio je idealan za neolitsko stanovništo, a posebno za nosioce starčevačke kulture. Poznato je, naime, da se većina starčevačkih nalazišta formirala oko slanih izvora na prostoru Balkana, kao što su Janica u Solunskom zalivu, Anzabegovo, Ovče polje, Slatina-Sofia itd. (Tasić 2007: 13). Nekoliko kilometara sjevernije od lokaliteta Gornja Tuzla, na južnim obroncima Majevice, nalazi se rudnik soli Tetima, u blizini kojeg izvire rijeka Jala. Na osnovu geoloških saznanja, ovaj je region veoma bogat naslagama soli koje su se veoma često manifestovale u vidu kamene soli, a koje je nanosila rijeka Jala svojim tokom. Samim time Gornja Tuzla predstavlja najstarije naselje starčevačke kulture na prostoru sjeveroistočne Bosne, s obzirom na to da na svim ostalim lokalitetima nisu zabilježeni njeni elementi. Na osnovu nalaza keramike u Gornjoj Tuzli može se zaključiti da se starčevačka kultura u Bosni pojavljuje tek sa zrelom fazom svog razvoja, odnosno u vremenu procvata starčevačke kulture u matičnom predjelu, s obzirom na to da se od šest determinisanih stratuma samo posljednji (stratum VI), koji se dijeli na dvije faze, pripada Starčevu.

\footnotetext{
57 Najranija proizvodnja keramike (slikane) na Bliskom istoku javlja se u zemljoradničkim društvenim kontekstima i datirana je u vremenskom periodu između 7066 i 6840 godina pr. n. e. (Budja 2014: 117).

58 U širem bi smislu obuhvatao Protosesklo kulturu u sjevernoj Grčkoj, kulturu Anzabegovo-Vršnik u sjevernoj Makedoniji i Čavdar-Kremikovci-Karanovo kulturu u Bugarskoj (Minichereiter 2007: 14).

${ }^{59}$ Keramika je pečena oksidacijskim postupkom, odnosno uz veću cirkulaciju zraka u peći, što je dovelo do toga da bude crvene ili oker boje.

${ }^{60}$ Posmatrano kroz prizmu centra i periferije, odnosno izvora jedne kulture i manifestacija identiteta prema susjednoj zajednici, dolazi do formiranja hibridne kulture nastale iz dvije zajednice (Kaljanac 2013: 64).

${ }^{61}$ Pretpostavlja se da su starčevačka naselja u Bosni i Hercegovini zavisila od migracionih pokreta uzvodno Savom i njenim pritokama ka sjeveroistoku i centralnoj Bosni i Hercegovini (Brukner 1976: 45).

${ }^{62} \mathrm{Na}$ osnovu istraživanja koje je sproveo na ovom lokalitetu, Benac je uvidio miješanje jadranske impresso kulture sa starčevačkom i taj je fenomen nazvao starčevačko-impresso kulturom (Benac 1972-73: 62).
} 
Sa sjeverne strane Majevice nalazi se lokalitet Varoš kod Koraja, ${ }^{63}$ na kojem je utvrđeno da najstariji slojevi pripadaju vinčanskoj kulturi, a koji su paralelni sa slojem V Gornje Tuzle, tj. s prelaznim slojem u kojem se miješaju nalazi Starčeva i Vinče (Čović 1960-61: 112). U Varoši, dakle, odmah nastupaju pravi vinčanski elementi bez tragova neke starije kulture na koju bi se nadovezali, što znači da su osnivaoci tog naselja u nekom trenutku prešli Drinu i formirali naselje na ovom prostoru. ${ }^{64}$ Identična je situacija i na drugim lokalitetima, poput Grbače i Matića, koji imaju čisti vinčanski karakter. Posljednja faza starčevačke kulture u literaturi se posmatra kao period u kojem jedna kultura nakon dugotrajnog života gubi svoju kulturnu snagu i identitet. Ta faza je paralelna sa najdubljim slojem Gornje Tuzle, odnosno fazom spiraloid B prema Stojanu Dimitrijeviću, koju odlikuje bikonizacija posuđa i manji broj slikane keramike. To ujedno predstavlja rane početke vinčanske tradicije na lokalitetu Gornja Tuzla (stratum V), odakle se ona dalje širila na prostor sjeveroistočne Bosne preko Majevice i niz dolinu rijeke Jale. Vinčanska kultura predstavlja jednu od najvažnijih kasnoneolitskih pojava u jugoistočnoj Evropi s kojom počinje novo neolitsko doba, period širenja i konsolidacije te pojava velikih naselja tipa tela (Tasić, Marić, Filipović, Penezić, Dunbar, Reimer, Barclay, Bayliss, Gaydarska, Whittle 2016: 2). Karakterišu je novine u odnosu na ranije periode, poput značajne promjene keramičke produkcije kako u tehnologiji pečenja, tako i u oblicima i tehnikama ukrašavanja, zatim veliki napredak u duhovnom životu koji karakteriše veliki broj pronađenih keramičkih figurina, te prva pojava metalurgije. ${ }^{65}$ Najviše je karakteriše glačanje tamnih, najčešće crnih keramičkih posuda, pa je zbog toga ta keramika i dobila naziv crna glačana keramika. Ipak, način života, zemljoradnja, poljoprivreda, arhitektura i prehrana nisu se u značajnoj mjeri promijenili u odnosu na ranije periode. Matični prostor vinčanske kulture na vrhuncu svog postojanja podudarao se u značajnoj mjeri sa teritorijom srednjeneolitske starčevačke kulture (Tasić 2008: 21). Značajna je razlika kada je u pitanju prostor sjeveroistočne Bosne, gdje se razvio dosta veći broj naselja u odnosu na vrijeme starčevačke kulture, dok je npr. u Slavoniji poznat samo jedan lokalitet vinčanske kulture, Bapska-Gradac (Burić 2014: 42) ${ }^{66}$. Prema navedenom, sjeveroistočna Bosna pripada tzv. balkansko-anadolskom kompleksu ranoneolitske starčevačke (slikane) i kasnoneolitske vinčanske (glačane) keramike, čiji su nositelji dolaskom na ove prostore podigli

\footnotetext{
63 Broj katastarske čestice: dio 265, 266/1, 266/2, opština Koraj, broj zemljišnog uloška: 84/04, 442/01, 290/01, 439/03, 809/03 (Elaborat 1990: 15.A).

${ }^{64}$ Izvan područja sjeveroistočne Bosne teško je govoriti o nekom jačem uticaju vinčanske kulture, s obzirom na to da se u centralnom dijelu formirala butmirska, a u južnom lisičićka kultura.

${ }^{65} \mathrm{Na}$ lokalitetu Gornja Tuzla Čović je u vinčanskom stratumu III pronašao 22 male bakrene perle, spiralni prsten i fragmenat tanke bakarne žice okruglog presjeka (Čović 1960-61: 98).

66 Burić navodi da ovaj podatak u ovom trenutku ipak treba uzeti sa izvjesnom rezervom, budući da postoje lokaliteti u Baranji, na istočnim padinama Banskog brda uz samu obalu Dunava, koji su istraživani u manjoj mjeri, a pokazuju neke obrise vinčanskih lokaliteta (figuralna plastika).
} 
najranija poznata naselja u sjeveroistočnoj Bosni od kojih su neka, poput Gornje Tuzle, i danas naseljena.

Svakako da je bilo više faktora koji su uticali na naseljavanje neolitske populacije na određene prostore, poput geografskih i klimatskih faktora, prirodnih resursa, hidrografske situacije, plodnosti tla, od kojih je mogućnost zemljoradnje bila glavni uslov koji je trebalo ispuniti kako bi se odabrala lokacija. Najveći broj neolitskih naselja u sjeveroistočnoj Bosni lociran je na obalama rijeka ili potoka, ili na uzvišenim platoima iznad riječnih dolina. S obzirom na to, razlikuju se dva tipa naselja vinčanske grupe u sjeveroistočnoj Bosni: naselja u obliku tela (Gornja Tuzla, Varoš, Grbača, Matić) i naselja na istaknutim brežuljcima. Naziv tel dolazi od arapske riječi tell u značenju umjetni humak, brdo (Rosenstock 2005: 221), ${ }^{67}$ dok se fenomen tela definira kao višeslojno naselje koje se razvilo na određenim geografskim područjima i karakteriše ga debeli kulturni sloj koji u kontekstu vremena dokazuje dugotrajnost života na lokalitetu. ${ }^{68} \mathrm{~S}$ obzirom na nivo istraženosti odnosno neistraženosti neolita sjeveroistočne Bosne, teško je govoriti o građevinskim karakteristikama, ali zahvaljujući nekoliko rezultata iz sondi u Varoši i Korića hanu mogu se iznijeti neki osnovni zaključci. Naime, kuće su postavljane polukružno uz ivicu tela koji se uglavnom sa južne i istočne strane blago spuštao, dok je sa sjeverne i zapadne strane nešto strmije odsječen. Prema Bencu, ovakav je oblik najvjerovatnije biran radi izolacije, a možda i radi odbrambenih razloga, posebno kada se uzme u obzir da je dosta naselja izgrađeno na močvarnim predjelima i oko njih. Oblici kuća nisu utvrđeni, ali uočeno je značajnije pridavanje pažnje podnicama koje su kvalitetno rađene, vjerovatno radi spriječavanja vlage. U sklopu toga, na osnovu nalaza ognjišta može se zaključiti da su ona građena kao sastavni dio podne konstrukcije i da su bila otvorenog tipa, dok su zidovi građeni od lijepa i drva.

\footnotetext{
${ }^{67}$ Lokalni sinonimi su höyük, grĉka magoula, makedonska toumba, slavenska mogyla, engleski naziv mound settlement. ${ }^{68}$ U suštini, tel predstavlja kontinuirano naselje koje zadovljava neophodne potrebe za životom, prilikom čega se dugogodišnjim boravkom stvaraju duboke strukture trajnog života, odnosno telovi.
} 


\section{GORNJA TUZLA}

\section{4a Zbog čega se Gornja Tuzla nije desila u Tuzli?}

Kompleksnost geološke građe i petrografskog sastava sjeveroistočne Bosne rezultat je duge geološke prošlosti u toku koje su se dešavale razne promjene koje su direktno uticale na prahistorijsko kopno. Geološko stvaranje terena Bosne i Hercegovine vezuje se za kaledonskohercinski orogeni ciklus u paleozoiku te alpski orogeni ciklus u mezozoiku i kenozoiku, čijom je orogenezom formiran dinarski planinski sistem. Područje sjeveroistočne Bosne nalazi se u okviru geotektonskog kompleksa Unutrašnjih Dinarida (Kudumović-Dostović 2017: 20). Početkom neogena na prostoru srednje i jugoistočne Evrope nastalo je veliko unutrašnje more, skoro paralelno sa Tetisom, ${ }^{69}$ nazvano Paratetis (staro more), u čijem su okviru egzistirali različiti bazeni: Panonski, Dakijski, Pontski itd. Područje sjeverne Bosne tokom miocena pripadalo je centralnom Paratetisu i za to se vrijeme, između rijeka Drine i Bosne, Panonski bazen zavlačio u kopno Bosne i Hercegovine sve do Tuzle, na taj način formirajući tuzlanski zaliv. Sjeverna Bosna je početkom miocena bila u potpunosti pokrivena Paratetisom, tako da se samo u okviru Tuzlanskog bazena nataložilo različitih sedimenata debljine oko 2.000 metara (Baraković 2007: 322). Za vrijeme pliocena, u okviru Panonskog bazena, u tuzlanskom zalivu između rijeka Drine i Bosne, uglavnom se vrši taloženje u slatkovodnim jezerskim prostorima, jer više nema morske sedimentacije. Na krajnjem jugoistoku lista Tuzla nataložena je serija slatkovodnih sedimenata u čiji sastav, pored glina, laporaca i pješčara, ulaze piroklastične tvorevine kao na primjer tufni pješčari, tufiti i tufovi, tufozne breče i konglomerati. Ova slatkovodna serija sedimenata na susjednim terenima leži u konkordantnom odnosu ispod tortonskih marinskih sedimenata i njena je starost određena kao donjisrednji miocen (Baraković 2007: 323).

Tuzlanski bazen odlikuje vrlo složena geološka građa i geološka evolucija, naročito u paleozojskom i mezozojskom periodu. Tercijarne tvorevine na listu Tuzla javljaju se na površini od oko $1000 \mathrm{~km}^{2} \mathrm{i}$ zahvataju blizu dvije trećine od ukupne površine terena. Zahvaljujući interesovanju geologa za što potpunijim poznavanjem ovih naslaga doprinijelo je i prisustvo različitih mineralnih sirovina: ležišta kamenih ugljeva, kamene soli, mrkih ugljeva, pojava nafte, ležišta lignita, kvarcnog pijeska, glina i litotamnijskih krečnjaka. Zahvaljujući rezultatima istraživanja koja traju duže od jednog stoljeća, stub tercijarnih tvorevina zastupljenih na listu Tuzla u osnovi je riješen. Izdvojeni su raznovrsni

\footnotetext{
69 Nekadašnja Tetis geosinklinala nalazila se između afričke ploče na jugu i eurosibirske ploče na sjeveru. To je bio
} okeanski prostor na kojem su se formirale stijenske formacije različite starosti i sastava. 
marinski sedimenti paleogena, zatim jezerske, marinske, brakične i kaspibrakične naslage neogena, kao i produkti vulkanskih aktivnosti koje su bile intenzivne u drugoj polovini donjeg i početkom srednjeg miocena. Sedimenti eocenskog stratigrafskog člana izgrađuju veći dio planine Majevice i konstatovani su u građi njenog glavnog grebena, pa u litološkom pogledu Majevica je najrazvijeniji član eocenskog sedimentnog kompleksa. U njegov sastav ulaze krečnjaci, laporci, alevroliti, glinci, pješčari i konglomerati. U oligocenu su izdvojeni sedimenti koji leže konkordantno ispod slavinovićkih krečnjaka u tuzlanskom bazenu. U tjemenu antiklinale Jala-Požarnica otkriveni su samo najmlađi sedimenti oligocena. Ove naslage najveće prostranstvo imaju na terenu između Požarnice, Stolice i Okruglice do Priboja. Javljaju se kao uzane zone, naročito u sjevernom rubu Tuzlanskog bazena. Na terenu lista Tuzla tokom neogena trajala je kontinualna kopnena i marinska sedimentacija, uz intenzivnu vulkansku aktivnost burdigalske i helvetske starosti. Obrazovane su raznovrsne, uglavnom sedimentne tvorevine, koje u Tuzlanskom bazenu imaju debljinu od preko $2.500 \mathrm{~m}$. U genetskom smislu zastupljene su raznovrsne tvorevine: (slatkovodne, slanojezerske, marinske, brakične i kaspibrakične) u okviru stratigrafskih članova: akvitan, hurdigal-helvet, torton, sarmat, pont i panon.

Tereni koje zahvata Tuzlanski bazen intenzivno se proučavaju već više od 100 godina. Veliki interes geologa za ove terene poticao je od složene geološke građe i sklopa tih terena, a posebno zbog prisustva ekonomski značajnih resursa uglja i kamene soli. Prve podatke o geološkoj građi dao je 1880. godine E. Tietze (Babajić, Mandžić, Salihović 2011: 67), koji je opisao ugljene slojeve Ugljevika. Prvo proučavanje sedimenata sone formacije izvršio je A. Boue još u drugoj polovici 19. stoljeća (Čičić, Redžepović 2005: 3) i pojavu slanih voda vezivao je za sedimente verfenske starosti. $^{70}$ Katzer je još 1903. godine (Isabegović 2011: 480), proučavajući tuzlanske sononosne sedimente, raščlanio sonu formaciju na podinske klastične crvene sedimente, sononosne prugaste laporce i gornjotuzlanske pločaste krečnjake. On sonu formaciju prvo ubraja u donji miocen, da bi kasnije došao do zaključka da pravog marinskog donjeg miocena u sjevernoj Bosni ipak nema, pa 1919. godine navodi da slana formacija potiče zapravo iz eocena. I. Soklić se još od 1948. godine bavi rješavanjem geologije šireg prostora Tuzlanskog bazena, proučavajući razvoj sedimenata eocena, oligocena, sone formacije, marinskih i kaspibrakičnih naslaga miocena, kao i tektonske karakteristike šireg prostora. On također 80-ih godina uspijeva da dokumentuje svoja ranija tvrđenja da je tuzlansko i gornjotuzlansko ležište kamene soli gornjohelvetske (karpatske) starosti (Soklić 1982: 140).

\footnotetext{
${ }^{70}$ Prema Katzeru, prvi koji se ozbiljnije bavio pitanjem geologije Balkanskog poluostrva bio je Ami Boue kome se s pravom daje počasna titula osnivača geologije Bosne i Hercegovine (Katzer 1926: 25).
} 
U dužem razdoblju P. Stevanović se bavio proučavanjem sedimenata sone formacije Tuzle, a naročito pliocenskih ugljenosnih sedimenata. Nakon proučavanja terena između Tušnja i Plješevice, P. Stevanović i M. Eremija 1961. godine obrađuju burdigal-helvetsku sonu formaciju, srednje i gornje miocenske marinske odnosno brakične naslage. U pogledu geneze sone formacije autori iznose slijedeće: Crvenom serijom otpočinje novi litološki ciklus koji se završava tuzlanskim pločastim krečnjacima, ciklus kojim obuhvata postanak, razviće $i$ iščeznuće lagunskog režima u okolini G. Tuzla (Čičić, Jovanović, Mojičević, Tokić 1991: 11). Č. Jovanović je u toku proučavanja sone formacije izradio litofacijalne karte za pojedine horizonte i izdvojio perspektivna područja za nalazak ležišta kamene soli. U brojnim rukopisnim radovima, a posebno u saradnji sa S. Čičićem, dao je dokumentacioni materijal za egzistenciju slano-jezerskog režima sedimentacije u razdoblju od gornjeg oligocena do tortona, čiji je najistaknutiji produkt sol

na formacija sa ekonomski značajnim ležištima soli. Na osnovu geoloških istraživanja sone formacije ležišta Tetima kod Tuzle, realizovanih u periodu 1971.-1983. godine, O. Jovanović i Č. Jovanović konstatovali su slijedeće: Brojnim mikropaleontološkim ispitivanjima, kao $i$ proučavanjima preparata u okviru sedimentoloških ispitivanja nisu utvrđeni nikakvi mikropaleontološki ostaci pa čak ni nađene slatkovodne forme gastropoda i fauna ostrakoda. Navedene činjenice ukazuju da sedimenti trakaste serije ne predstavljaju produkt lagunske hemijske sedimentacije (Vrabac, Ferhatbegović, Đulović, Bijedić 2010: 2). Saglasno tome, Č. Jovanović i S. Čičić smatraju da solna formacija predstavlja produkt formacije u slanom jezeru tokom gornjeg burdigala-helveta odnosno donjeg miocena, što je za posljedicu imalo pretpostavku da je solna formacija tvorevina tuzlansko-loparske slane lagune koja pripada karpatskom gornjem burdigalu. Na osnovu ispitivanja faune ježinaca došlo se do zaključka da donji dio tuzlanskog šlira zapravo pripada helvetu (Soklić 1982: 142). Šlir u suštini predstavlja morske sedimente koji leže poviše tuzlanskog pločastog krečnjaka, i riječ je o tamnosivim i sivim fino uslojenim laporcima koji su taloženi u dubljim slojevima bazena tokom burdigala, odnosno u Tuzli je zastupljen u slojevima koji pripadaju karpatu te donjem i srednjem badenu (Soklić, 1982: 82).

Ipak, postoji i druga struja koja zastupa mišljenje da je solna formacija nastala u navedeno vrijeme, ali u zalivu Paratetisa. Postavlja se pitanje nastanka sone formacije tuzlanskog bazena, pa jedna teorija tvrdi da je solna formacija nastala u morskom zalivu Paratetis tokom donjeg miocena odnosno karpata, a druga teorija kaže kako je solna formacija nastala u donjem miocenu, ali u slanom jezeru. Ako su ležišta soli nastala u okviru slanog jezera, to je i potencijalna površina njihovog rasprostranjivanja ograničena samo na prostore tuzlanskog i loparskog bazena. Međutim, ako se pretpostavi da je geneza ležišta vezana za morski zaliv, onda je logično pretpostaviti da je na području sjeverne Bosne, pa i šire u okviru karpatskog mora, postojalo još sličnih paleografskih 
prostora u kojima su se mogla obrazovati ležišta soli (Vrabac 1991: 190). Danas se pretpostavlja da je S. Vrabac 1991. godine riješio dilemu o genezi sone formacije prilikom pronalaska mikroforaminifera u sonoj formaciji na izdancima kod Gradine u Tuzli, odnosno da je dokazao njeno morsko porijeklo. ${ }^{71}$ Tokom 2008. godine na ležištu kamene soli Tetima rađena je istražnoeksploataciona bušotina i dala određene rezultata koji svjedoče da početak transgresije Paratetisa na prostor sjeverne Bosne nije vezan za donji miocen (karpat), nego za srednji miocen odnosno donji baden, kada je u okviru zaliva na prostoru Tuzlanskog bazena taložena solna formacija (Vrabac, Ferhatbegović, Đulović, Bijedić 2010: 2). Ovaj podatak znatno je izmijenio stratigrafiju marinskog neogena tuzlanskog bazena i sjeverne Bosne. U tom kontekstu je pomjeran vremenski period nastanka sone formacije tuzlanskog bazena. Solna formacija je prije tretirana kao donjomiocenska, a prema ovim novim podacima ona je ipak formirana u srednjem miocenu odnosno donjem badenu (Vrabac, Ćorić 2008: 72). Prisustvo marinskih karpatskih sedimenata do sada je utvrđeno na području Hrvatske i Srbije, pa prema tome postojanje marinskog karpata na prostoru sjeverne Bosne nije sporno, posebno nakon što je utvrđeno da debljina marinskih karpatskih sedimenata na bušotinama iznosi oko $280 \mathrm{~m}$. Na osnovu sedimenata tog profila uočava se da je taloženje nastajalo u uslovima otvorenijeg mora i da je njihov stariji dio vjerovatno vremenski ekvivalentan sonoj formaciji (Vrabac 1991: 191). Prema navedenim rezultatima istraživanja o sonoj formaciji, utvrđeno je dovoljno osnove da se dođe do zaključka o genezi ležišta kamene soli tuzlanskog bazena u zalivu karpatskog mora.

U dugogodišnjim istraživanjima dokanjske sinklinale u sonoj fromaciji Tetime kod Gornje Tuzle pronađeni su morski fosili koji predstavljaju pouzdanu osnovu za definisanje geneze i vremena nastanka kamene soli u ovom dijelu Tuzlanskog bazena. Dugo vremena se smatralo da solna formacija Tuzlanskog bazena ne sadrži nikakve fosile izuzev palinoloških ostataka. Erozionim faktorom na prostoru dokanjske sinklinale, koja ima dužinu od $15 \mathrm{~km}$ i nalazi se sjeverozapadno od Tetime, došlo je do nagiba od $17^{\circ}$ prema jugu, iz čega se može zaključiti da je nakon privremenog povlačenja i erozije obale more ponovo prekrilo bazen i istaložilo svoje nove sedimente (Soklić 1986: 40), što bi išlo u prilog prethodnoj teoriji. Na južnom krilu dokanjske sinklinale, sjeverno od Gornje Tuzle, vidljivi su na terenu odsjeci poprečnih rasjeda sa lijevim horizontalnim pomakom, što ukazuje na gravitaciono kretanje bazenskih naslaga niz sinklinalu. ${ }^{72}$ Geografski položaj Tuzlanskog

\footnotetext{
71 Miocen je zastupljen veoma debelim kompleksom sedimenata u Tuzlanskom bazenu na čijem je prostoru trajala marinska sedimentacija, kada je formirana solna formacija u okviru dokanjske sinklinale i u slivu rijeka Jale i Soline (Kudumović-Dostović 2017: 23).

${ }^{72}$ U panonskom bazenu bilo je oplićavanja i pretvaranja bazena u kopno (obodnih dijelova), kao i tonjenja dna uz sažimanje naslaga. Strukturna karta ukazuje na dekstralno pomjeranje duž uzdužnog rasjeda pružanja sjeverozapad-
} 
bazena sklon je takvim tektoničkim pokretima s obzirom na to da se nalazi između dvije veće strukturno - tektonske jedinice: Greben Majevice (kredno - paleogeni klastiti) na sjeveru i neotektonske jedinice Sprečanska depresija na jugu. Tuzlanski bazen čini nekoliko tektonskih jedinica: tuzlanski ubrani plato, dokanjski bazen te planina Majevica, a kroz sve jedinice protiče rijeka Solina kao glavna komunikaciona linija. ${ }^{73}$ Reljef sliva rijeke Soline pretežno je brdsko brežuljkastog karaktera i djelovanjem orogenih faza dolazi do radijalnih tektonskih pokreta izdizanja horsta Majevice u sjevernom dijelu sliva te do pokreta nabiranja i izdizanja u južnom dijelu (tuzlanski ubrani plato) (Hadžimustafić, Suljić, Baraković 2007-08: 215). Ovakvi tektonski pokreti nisu strani Tuzli ni danas, s tim što je izdizanje mnogo intenzivnije u prostoru Majevice nego na jugu kod tuzlanskog ubranog platoa, dok prostor dokanjskog bazena danas stagnira više nego što tone. Proces slijeganja terena prirodnim, a posebno vještačkim izlučivanjem soli naglo se ubrzao posljednjih tridesetak godina zbog veće eksploatacije. Pojava slijeganja terena uslijed podzemne ekstrakcije soli bila je poznata još početkom 20. stoljeća - iz dnevnika geologa F. Katzera vidi se da se o slijeganju vodilo računa (Soklić 1991: 135).

jugoistok dužine 1,5 km. Na platou Dobošnica (Tuzlanski bazen) vidljivi su tragovi jake erozije iz vremena atičke faze (Soklić 1991: 9).

73 Posmatrano iz strukturalnog aspekta, najveći dio tuzlanskog gradskog područja pripada ubranom platou koji se još od kraja miocena relativno brzo tektonski izdiže. 


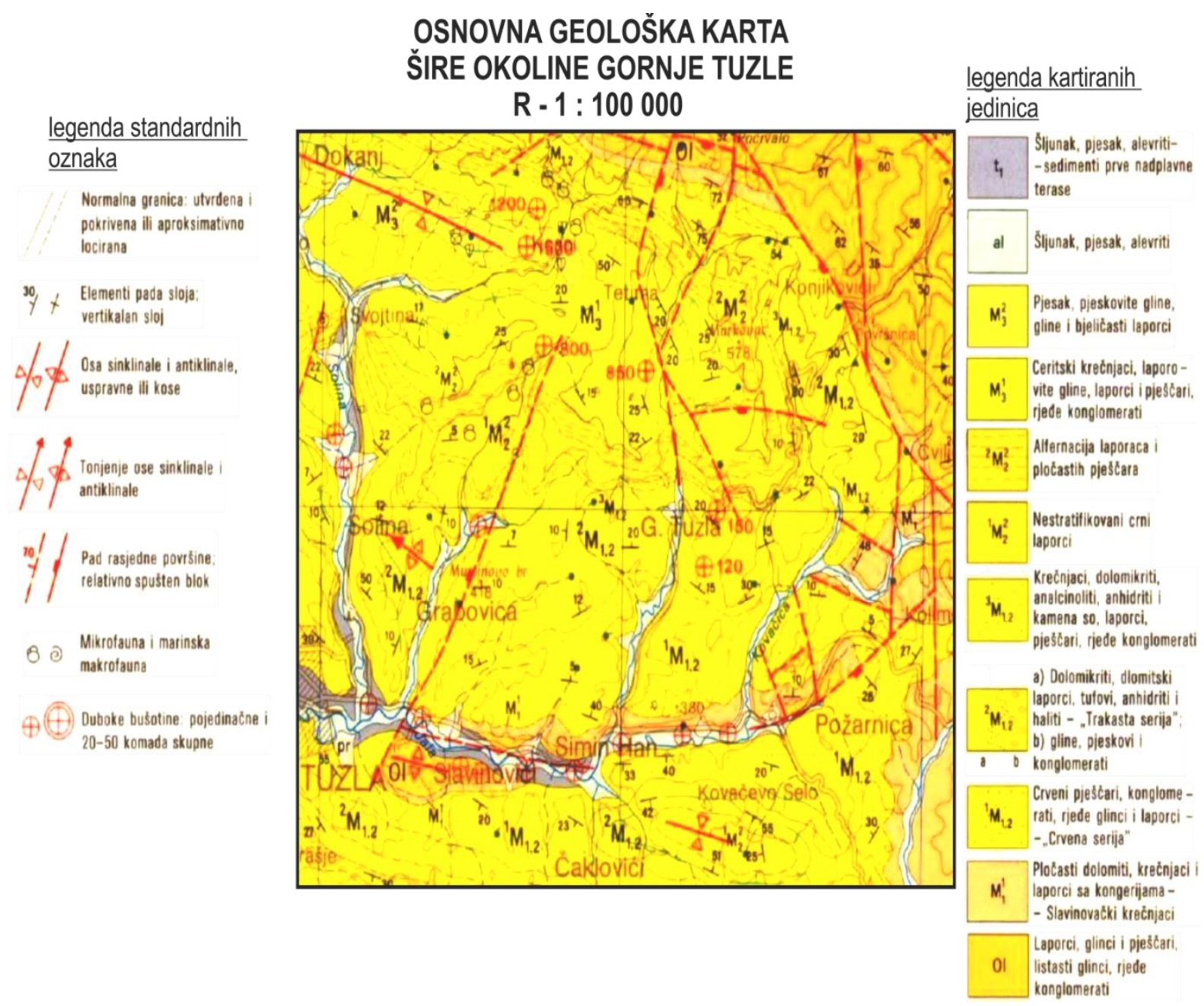

Slika 14. Geološka karta Tuzlanskog bazena (1: 100 000) (izradio E. Babajić)

Danas na području Tuzle postoje dva aktivna rudnika soli od kojih je jedan u neposrednoj blizini lokaliteta Gornja Tuzla, na području Tetime koja se nalazi sjevernije u odnosu na lokalitet. Ležište kamene soli Tetima smješteno je na južnim obroncima Majevice, oko $12 \mathrm{~km}$ sjeveroistočno od Tuzle, svega nekoliko kilometara sjevernije od Gornje Tuzle. Zahvata površinu od oko $106 \mathrm{~m}^{2}$, a u planu ima nepravilan elipsoidalan oblik s dužom osi većom od $2.000 \mathrm{~m}$ i s kraćom od oko $1.000 \mathrm{~m}$. Tuzlanski bazen u širem geografsko-geološkom aspektu pripada Panonskom bazenu i situiran je na području između $44^{\circ} 20^{\prime} 44^{\prime \prime}$ sjeverne geografske širine, te $18^{\circ} 30^{\prime}$ i $19^{\circ} 00^{\prime}$ istočne geografske dužine po “Greenwich?”. U orografskom smislu teren je vrlo složen. Njegovi južni dijelovi pripadaju ograncima planine Konjuh. Heterogen sastav odrazio se i na reljef koji karakterišu oštri oblici. Teren se blago spušta u drugu orografsku cjelinu koja obuhvata akumulacioni ravničarski reljef Sprečke depresije sa nadmorskim visinama od 200-230 m. Sjeverni dio terena pripada planini Majevici, koja u morfološkom i strukturno-tektonskom pogledu predstavlja horst između Sprečkog polja na južnoj i 
Posavine na sjevernoj strani. Greben Majevice je dinarskog smjera, jasno izražen u morfologiji sa najvećim vrhom Majevice (915 m), odakle se teren blago spušta ka Sprečanskoj depresiji a izgrađen je uglavnom od neogenih naslaga tuzlanskog bazena (Soklić 1986: 39). Jedna od značajnijih odlika terena jeste gusta riječna mreža preko koje se dolinom Spreče i njenih pritoka Gostije, Oskove i Jale, a manjim dijelom i preko Tanje, rijeke ulijevaju u Savu. Krajnji istočni dio pripada slivu Drine u koju se ulijevaju Modranica, Sapna i druge manje riječice i potoci.

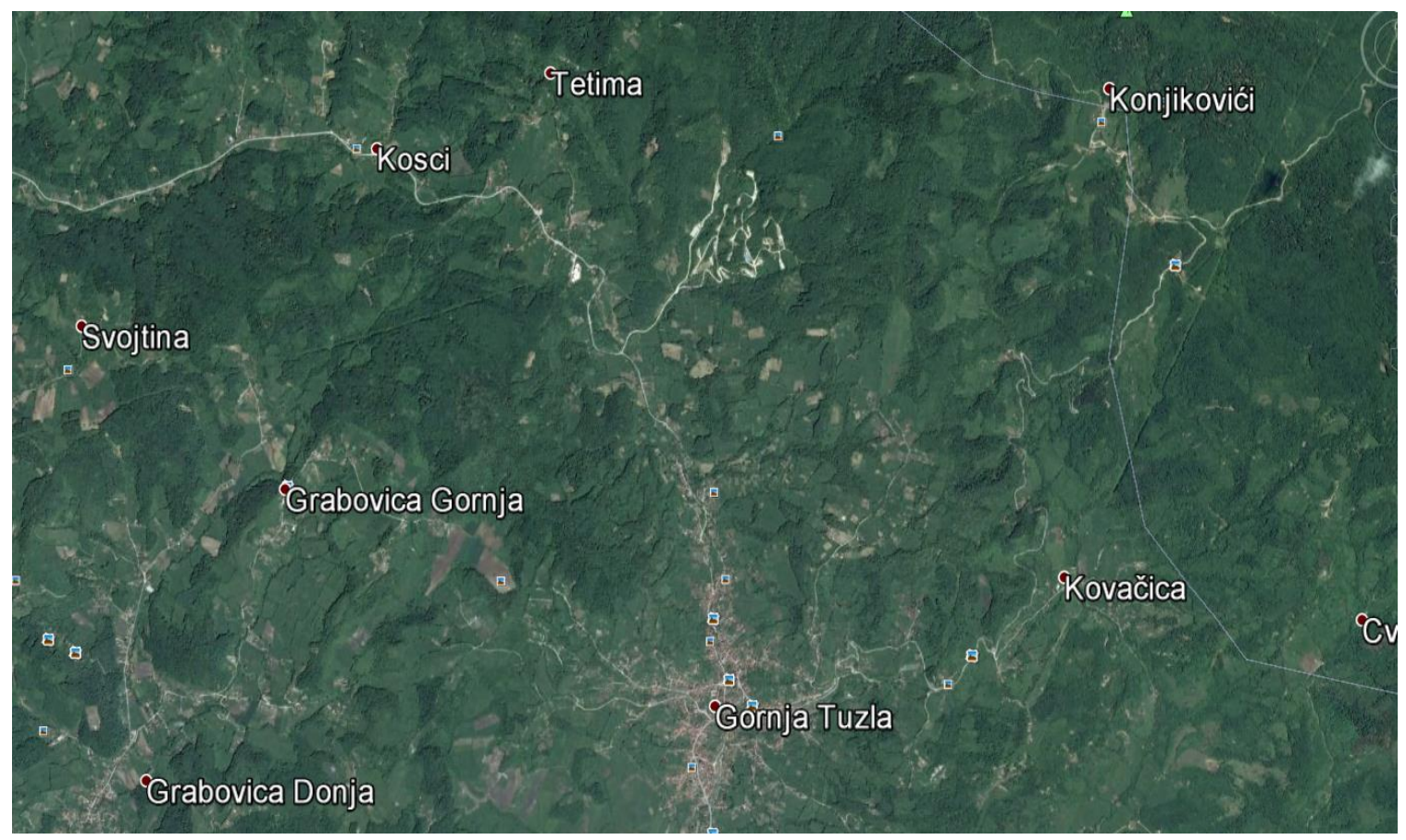

Slika 15. Položaj Gornje Tuzle u odnosu na rudnik soli Tetima (Google maps, 2017)

Ležište kamene soli Tetima izgrađeno je od jednog solnog tijela lećasto-slojevitog oblika, koje se pruža smjerom sjeverozapad - jugoistok s padom prema jugozapadu. Dubina zalijeganja je na jugoistoku $400 \mathrm{~m}$, a na sjeverozapadu oko $1.000 \mathrm{~m}$, što daje prosječan pad od $16^{\circ}$, iako taj pad u dijelovima okomitim na pružanje iznosi i do $30^{\circ}$. Najveća debljina solnog tijela iznosi $150-180 \mathrm{~m}$ i ide paralelno sa dužom osi, kroz centar ležišta, dok prema rubovima ležišta solno tijelo potpuno isklinjava. Ležište je srednjemiocenske starosti (donji baden), a deponovano je u istočnom-čeonom dijelu dokanjske sinklinale (Nuhanović 2010: 2). Područje dokanjske sinklinale, u kome se nalazi ležište kamene soli Tetima, predstavlja izrazito brdski teren s velikim padom i visinskom razlikom od $200 \mathrm{~m}$. Sam teren je prilično razuđen i većim dijelom pokriven šumom. Generalno, čitav teren pada ka jugu, u pravcu Jale koja predstavlja glavnu drenažu prirodnih voda sa ovog područja. Mineraloška ispitivanja kamene soli u ležištu Tetima vršena su makroskopskom analizom, odnosno 
kartiranjem jezgra dobivenih iz izgrađenih bušotina. Sol je u ležištu najviše zastupljena u krupnozrnim agregatima, iako se mogu konstatovati i sitnozrni agregati, kao i prisustvo idiomorfnih kristala tipičnih za halit koji predstavlja mineral nastao od natrijevog hlorida, šire poznat kao kamena sol. Boja soli varira, ali je najčešće siva, s tim što je primjetna zavisnost boje od veličine zrna, jer je sitnozrna sol svjetlijih boja, dok su krupni, idiomorfni kristali tamnosive boje.

Kamena sol $^{74}$ miocenske starosti (donji baden) odlikuje se finom usporednom slojevitošću i trakastom teksturom. Solno tijelo izgrađeno je od halita, s rijetkim slojevima laporca, debljine do 2 m. U neposrednoj podini sone formacije zastupljeni su slatkovodni jezersko-riječni donjomiocenski sedimenti. Oni su predstavljeni raznovrsnim klastitima, ${ }^{75}$ sa slojevima tufa. ${ }^{76}$ Boja im je crvena i šarena. Najnovija istraživanja pokazala su da je ove dvije serije opravdano zvati "klastično piroklastična formacija", 77 koja predstavlja donjomiocensku podinu sone formacije. Tektonska koncentracija soli nastala je u centralnom i istočnom dijelu ležišta. Na osnovu odnosa soli i jalovine utvrđen je srednji sadržaj soli u cijelom ležištu, koji iznosi 96,7\%, dok je prosječni sadržaj $\mathrm{NaCl} u$ solnom tijelu 93,75\%, a nerastvorljivi ostatak 3,46\% (tabela 3). Od produkata hemijske sedimentacije u ležištu se javljaju monomineralne tvorevine, prije svega naslage halite $-\mathrm{NaCl}$, zatim glauberove soli (mirabalita), $\mathrm{Na}_{2} \mathrm{SO}_{4}$ x $10 \mathrm{H}_{2} \mathrm{O}$ i anhidrita, $\mathrm{CaSO}_{4}$ (Nuhanović 2010: 7).

\footnotetext{
74 Pojave kamene soli vezane su za sedimente sone formacije burdigal-helvetske starosti. Sedimenti sone formacije izgrađuju terene Tuzlanskog i Šibošničko-loparskog bazena. Najveća debljina čiste kamene soli u ležištu Tetima iznosi 180 metara.

${ }^{75}$ Klastične stijene (klastiti) - sedimentne stijene koje se sastoje od čestica nastalih razaranjem starijih stijena. Mogu biti različitih dimenzija: ruditi, areniti, lutiti.

76 Pršinac ili tuf je vrsta sedimentne stijene vulkanskog porijekla. Nastaje taloženjem te sljepljivanjem sitnijeg vulkanoklastičnog materijala, poput vulkanskog pepela. Zbog toga se može pronaći oko ugašenih $i$ aktivnih vulkana. Ime je dobio po italijanskoj riječi tufo - meka, rastresita, pjeskovita masa (stijena). Iako je ime izvedeno od riječi prhak, ovaj je kamen čvrst. Može se javiti u slojevima, ali i kao masivna stijena, zbog čega se koristi i u građevinarstvu.

77 Piroklastične (vulkanoklastične) stijene su posebna skupina klastičnih sedimentnih stijena. Nastale su od materijala izbačenog vulkanskim erupcijama, sastavljenog od očvrsle lave i fragmenata stijena kroz koje lava prodire.
} 
Tabela 3. Osnovni pokazatelji kvaliteta soli u ležištu Tetima (Nuhanović 2010: 8)

\begin{tabular}{|c|c|c|c|c|c|c|c|c|c|c|}
\hline \multicolumn{2}{|c|}{ Prosječan sadržaj soli i NaCl u sonom tijelu } & \multicolumn{5}{|c|}{ Prosječan hemijski sastav soli (\%) } \\
\hline $\begin{array}{c}\text { Moćnos } \\
\text { t solnog } \\
\text { tijela }\end{array}$ & $\begin{array}{c}\text { Moćnos } \\
\mathrm{t} \text { soli } \\
(\mathrm{m})\end{array}$ & $\begin{array}{c}\text { Moćnos } \\
\mathrm{t} \\
\text { jalovine }\end{array}$ & $\begin{array}{c}\text { So u } \\
\text { solno } \\
\mathrm{m} \\
\mathrm{tijelu} \\
(\mathrm{m})\end{array}$ & $\begin{array}{c}\mathrm{NaCl} \mathrm{u} \\
\text { solno } \\
\mathrm{m} \\
\mathrm{tijelu}\end{array}$ & $\mathrm{NaCl}$ & $\mathrm{SO}_{4}^{-}$ & $\mathrm{Ca}^{+}$ & $\mathrm{Mg}^{+}$ & $\mathrm{HCO}_{3}$ & $\begin{array}{c}\text { Nerastv } \\
\text { ostatak }\end{array}$ \\
\hline 91,59 & 88,53 & 3,00 & 96,66 & 93,75 & 95,79 & 0,37 & 0,17 & 0,06 & 0,109 & 3,46 \\
\hline
\end{tabular}

Nenad Tasić je ustanovio hipotezu o vitalnom značaju soli za neolitske populacije na Balkanu i svoju ideju potvrdio kartiranjem ranoneolitskih nalazišta (Tasić 2012: 213) te ih uporedio sa poznatim depozitima soli kako bi došao do zaključka da je gotovo svako nalazište na neki način povezano sa solju. ${ }^{78} \mathrm{U}$ jugoistočnoj Evropi, neolitska naselja su se razvijala oko regiona bogatih izvorima soli, odnosno na prostoru Transilvanije i morskih obala, posebno na prostoru Grčke. Način na koji su neolićani dolazili do soli, odnosno tehnologija kojom su se koristili danas nije posebno poznata, osim kada su u pitanju pretpostavke o isparavanju slane vode, ekstrakciji soli iz blata ili filtraciji pepela slanih biljaka, ali sol se veoma često nalazila na površini zemlje, prirodnim isparavanjem slanih jezera i močvara. ${ }^{79}$ Prema ispitivanju jama i buština, taloženje soli se uglavnom odvijalo u ciklusima - nastajao je po jedan ciklotem, kao alternativna sekvenca marinskih i nemarinskih sedimenata, koji počinje laporcem i uz kojeg se često vežu i drugi hemijski talozi poput anhridita, da bi se taj proces zavšio taloženjem kamene soli (Soklić 1982: 142).

Zanimljivo je Tasićevo razmišljanje o upotrebi soli za vrijeme trajanja starčevačke kulture. Naime, kada se uzme u obzir teritorija za koju se pretpostavlja da je pripadala starčevačkoj kulturi, primjetno

\footnotetext{
78 Isti je slučaj na gotovo svakom nalazištu na području Levanta, gdje su naselja bila koncentrisana oko Jordana, rijeke koja se smatra bogatim izvorištem soli. Ni u Anadoliji situacija nije puno različita - ondje su slana jezera privlačila neolitske populacije.

${ }^{79}$ Dvije osnovne metode za produkciju soli su ekstrakcija i kopanje (rudnik). Geografski posmatrano, populacije koje su obitavale u blizini mora ili slanih jezera so su dobivale isparavanjem, dok su one u unutrašnjosti bile primorane otvarati rudnike soli, što je evenutalno rezultiralo stvaranjem trgovačkih puteva za razmjenu dobara. Postupak je uglavnom bio slijedeći: slana voda se sakupljala u velike keramičke posude koje su zatim postavljane na vatru. Nakon što voda prokuha, slane naslage su se izdvajale u manje posude u kojima se sol sušila i hladila.
} 
je da u centralnom dijelu nema solnih depozita, dok se na raznim perifernim područjima nalaze bogati rudnici soli. Takav je slučaj na istoku sa rudnicima soli u Transilvaniji, zatim na zapadu kod Gornje Tuzle te na krajnjem jugu u dijelovima kompleksa oko Tesalonikija. Činjenica je da na prostorima bogatim rudama soli dolazi do značajnije mješavine kulturnih elemenata, kao što je to slučaj na lokalitetu Gornja Tuzla, gdje dolazi do miješanja elemenata kultura Starčevo - Vinča. Gornja Tuzla predstavlja jedno od rijetkih nalazišta na Balkanu gdje dolazi do direktne korelacije dvije velike i značajne kulturne grupacije, Starčeva i Vinče. ${ }^{80}$ Samim time, u pitanju je jedno od značajnijih prahistorijskih nalazišta na prostoru ne samo Bosne i Hercegovine, već i u širem regionu u kojemu sol predstavlja okosnicu života bilo koje kulturne skupine koja se nastanila na ovom području.

Nesumnjivo da je sama lokacija nalazišta usko vezana za bogate izvore soli, kao za i riječicu Jalu koja izvire sa područja Tetime i svojim tokom nanosi slane depozite kojima su se neolićani gornjotuzlanskog regiona koristili. Uprkos važnosti soli, ${ }^{81}$ prije svega kao neophodnog minerala za ljudsko tijelo (doduše u nešto manjim količinima), ali i u ishrani stoke, literatura koja se bavi neolitskim periodom ne posvećuje veću pažnju njenoj ulozi pri formiranju i životu određenog naselja. ${ }^{82}$ Ipak, da je sol igrala značajnu ulogu pokazuje, između ostalog, višeslojno naselje u Gornjoj Tuzli sa konusnim oblicima posuda koji se povezuju sa produkcijom soli (Čović 1960/61; Chapman 1988: 12). Samim time, prema Tasiću, neolitska naselja bogata rudama soli, poput Gornje Tuzle, bila su bogatija u odnosnu na ostala savremena naselja, što najbolje pokazuje obilje keramike, ornamentalnih tehnika i motiva (Tasić 2000a: 40; Tasić 2000b: 1140; Tasić 2012: 215). U literaturi je poznato da mnogi autori smatraju kako višeslojna tel naselja (poput Gornje Tuzle) predstavljaju simbol moći i da su ondje živjele imućnije zajednice, jer se pretpostavlja da su takva naselja imala razvijenu zemljoradnju i uzgoj žitarica do te mjere da su proizvodila višak koji je bio distribuiran na tržište. Da je sol igrala značajnu ulogu u formiranju naselja i životu neolitskih zajednica najbolje pokazuje istraživanje lokaliteta Provadia u Bugarskoj, vršeno od 2005. do 2007. godine, gdje su pronađeni uvjerljivi dokazi o masovnoj produkciji soli iz slane vode (Nikolov 2012: 11). Tehnologija isparavanja soli, prema rekonstrukciji bugarskih istraživača, sastojala se od prokuhvanja u pećnicama "rasoli/slanice" (eng. brine) u keramičkim posudama veličine 5,5 do 35,5 litara. Posude su pravljene

\footnotetext{
${ }^{80}$ Granice vinčanskog kompleksa također su bile obilježene solju bogatim predjelima u Transilvaniji, Bosni i na jugu do Makedonije.

${ }^{81}$ Prvi koji je shvatio važnost soli za neolitske populacije bio je Gordon Childe (Childe 1929: 244), a nakon njega J. Nenquin sa knjigom Salt, a study in economic prehistory (1961) te Adshead (Salt and Civilization, 1992), a neki od najvažnijih podataka o ulozi i značaju soli pružio je N. Tasić kroz svoje istraživanje starčevačke kulture.

${ }^{82}$ Samo na području Balkana (Srbija, Rumunija, Bugarska, Makedonija, Bosna i Hercegovina) nalazi se najmanje 20 naselja sa toponimom "saline", od kojih se neka dovode u vezu sa neolitskim populacijama.
} 
sa širokim grlima i tanjim zidovima kako bi se slanica ranije ugrijala, što je pri zagrijavanju uzrokovalo isparavanje vode kroz otvor i pore zidova. Ovakva upotreba keramičkih posuda za proizvodnju soli dokazana je hemijskim ispitivanjem kojim su identificirani ostaci hlora, potasijuma i magnesijuma (Cavruc 2008: 80). ${ }^{83}$ Ovo otkriće najbolje pokazuje potrebu za soli neolitskih zemljoradničkih zajednica, što prema Tasiću potvrđuje njegove hipoteze da je u sjeveroistočnoj Evropi postojala proizvodnja soli na veliko (Tasić 2012: 215). Pored otkrića na lokalitetu Provadia, nekoliko godina kasnije pokrenut je i projekat pod vodstvom K. Penezić, A. Kadereit, H. Thiemeyera i N. Tasića. Projekat je za cilj imao da prikupi nove podatke o lokalitetima Starčevu i Vinči kroz geološke epohe. Prema inicijalnim rezultatima do kojih su istraživači došli, smatra se da je na prostoru između Starčeva i Vinče bila vidljiva površinska sol (Tasić 2012: 216).

Sol je za neolitske stanovnike Gornje Tuzle imala ključnu ulogu pri formiranju naselja koje će se održati kroz različite historijske procese do danas. Stvaranje solne formacije iz marinskih sedimenata starog mora, kroz duge geološke epohe, u direktnoj mjeri će uticati na odluku nosilaca starčevačke kulture prilikom odabira mjesta za podizanje najstarijeg naselja na prostoru sjeveroistočne Bosne. Geografski posmatrano, da bi naselili područje Gornje Tuzle, nosioci starčevačke kulture morali su zaobići planinu Majevicu, pod pretpostavkom da su do sjeveroistočne Bosne išli nizinskim predjelima niz dolinu rijeke Save i u nekom trenutku se spustili dolinom rijeke Drine; s obzirom na udaljenost Gornje Tuzle od navedenih rijeka, nameće se logičan zaključak da je ovaj prostor odabran ciljano. Gornja Tuzla je bila idealan izbor s obzirom na velike mogućnosti za razvoj stočarstva i zemljoradnje, uzmiajući u obzir bogatstvo pašnjaka i plodnost tla, ali i prisustvo riječice Jale čiji je izvor nekoliko kilometara sjevernije od lokaliteta. Ipak, navedene kriterije nije bilo teško ispuniti, posebno kada se uzme u obzir prirodno bogatstvo sjeveroistočne Bosne, pa se naselje moglo osnovati na većini mjesta ovog područja.

Sudeći prema navedenim istraživanjima o ulozi i značaju soli u ishrani ljudi i životinja, nameće se zaključak kako je upravo ovaj mineral, nastao dugotrajnim procesom iz sone formacije Tuzlanskog bazena, imao ključnu ulogu pri odabiru mjesta za podizanje prvih naseobina. Da je gornjotuzlanski predio izuzetno bogat rudama soli, govori i činjenica da se i danas rudnik soli Tetima aktivno bavi proizvodnjom te da se ondje na osnovu moderne tehnologije crpe slane naslage iz dubina i prerađuju u tuzlansku sol kakva se godinama prodaje. Također, veoma se često u stručnoj literaturi uz pomen Gornje Tuzle kao neolitskog naselja sjeveroistočne Bosne veže i termin "abundant rock-salt mine in east Bosnia".

${ }^{83}$ Naselje Provadia-Solnitsata datirano je u vremenskom periodu između 5400 i 5000 pr. n. e. (Cavruc 2008: 80). 


\section{4b Rezultati Čovićevih istraživanja}

Naselje Gornja Tuzla u svojoj dugogodišnjoj prošlosti nije doživjelo veliku zainteresovanost istraživača jugoslavenskog perioda, kada se uzme u obzir koliko vremena je bilo posvećeno istraživanju sjeveroistočne Bosne u odnosu na centralnu. Naime, lokalitet je istraživan nekoliko puta, s tim da je samo Čović sproveo detaljno sistematsko iskopavanje sonde II-1958, koju je uzeo kao stratigrafsku bazu, i kreirao stratume koji su i danas prihvaćeni među stručnjacima. Prvo probno sondiranje na ovom lokalitetu rađeno je 1955. godine sa ciljem da se utvrdi eventualno postojanje novih grobova željeznog doba, ali oni nisu pronađeni nego je po prvi puta ustanovljen kulturni sloj naselja ispod recentnih $0,60 \mathrm{~cm}$. Iste godine pregledana je jedna jama dubine $2 \mathrm{~m}$, iskopana prilikom građenja osnovne škole (Krečana, 1955). Jama se nalazila sjeveroistočno u odnosu na školu, i u njoj je konstatovan recentni sloj debljine $0,90 \mathrm{~cm}$ ispod kojeg se nalazio novi tamni rastresiti sloj debljine oko $1 \mathrm{~m}$, sa velikom količinom crvenkaste grube keramike. Naredne 1956. godine otvorena je još jedna sonda u neposrednoj blizini škole, u pravcu jugoistoka, veličine 3 x 4 m. Recentni sloj je, međutim, bio veoma debeo pošto se naišlo na neki stariji bunar, pa je sonda sužena samo na južni dio, od kojeg se odustalo zbog "male otkopne površine za precizno praćenje i malih raspoloživih sredstava" (Čović 1960-61: 80). Iduće 1957. godine otvorena je prva veća sonda dimenzija 7,5 x 4 $\mathrm{m}\left(30 \mathrm{~m}^{2}\right)$, u kojoj je prvi puta iskopan kompletan kulturni sloj i utvrđeno je postojanje starčevačkih elemenata. Jedine podatke o navedenoj sondi Čović je ostavio na mapi u koju je ucrtao rezultate sprovedenih sondiranja. Sudeći prema toj mapi, sonda II-1957 bila je dosta južnije u odnosu na školu. Također, u svega jednoj rečenici Čović navodi kako je sonda iskopana do kraja, ali da zbog njene lokacije na južnoj periferiji naselja nije fiksirana kompletna stratigrafija. Zdravica je u ovoj sondi pronađena na dubini od 2,70 m, što je dodatni pokazatelj za eventualnu lokaciju ove sonde, odnosno trebalo bi da je ona nekoliko metara sjevernije u odnosu na sondu I-2018, te dvadesetak metara istočnije. 


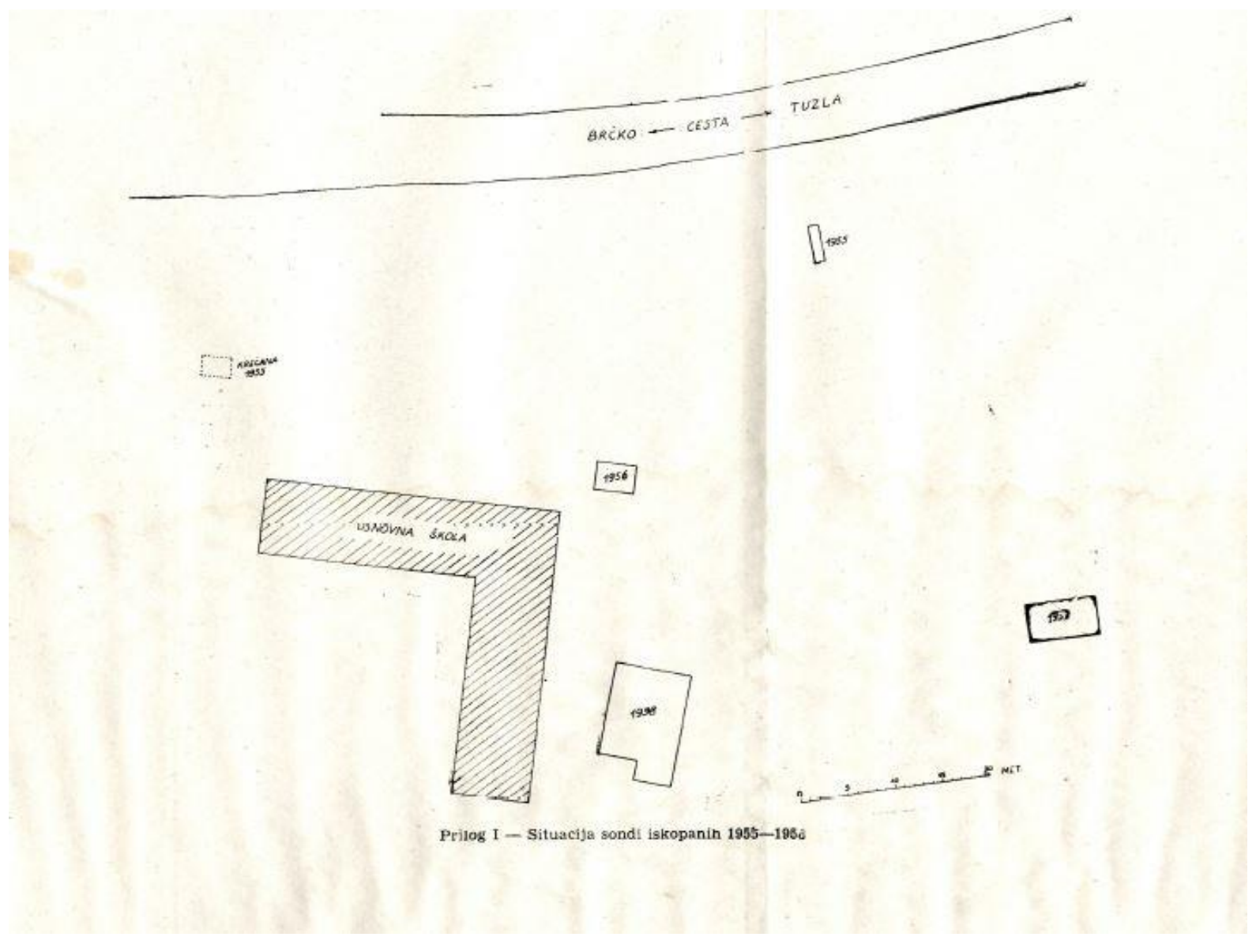

Slika 16. Raspored sondi iskopanih 1955.-1958. (Čović 1960-61: 80)

Sonda II-1958 predstavlja ujedno i najveću iskopanu sondu na ovom lokalitetu. Naime, Čović je otvorio sondu površine $88 \mathrm{~m}^{2}$ (iskopavanje starijih slojeva vršeno je samo na sjevernoj strani sonde površine $40 \mathrm{~m}^{2}$ ), ali njena lokacija je poznata samo na osnovu ucrtane mape. Ipak, prilikom radova na sondi IV iz 2018. godine, jedan je stariji gospodin iz susjedne bašče usmenim putem "potvrdio" lokaciju sonde iz 1958. godine, jer je, kako kaže, bio dječačić kada se kopalo u njegovoj bašči i sjeća se njene lokacije. U pitanju je katastarska čestica 607/3 koja pripada porodici Mehić i nalazi se svega nekoliko metara južnije od škole. Na osnovu rezultata sonde II-1958 Čović je identifikovao šest stratuma, i nalaze najdubljeg sloja determinirao kao starčevačke te na taj način potvrdio rezultate iz sonde I-1957 i lokalitet Gornja Tuzla svrstao među nastarije na prostoru sjeverne i centralne Bosne. Upravo zbog navedenog podatka, uz smjenu Starčeva u korist Vinče te obzirom na veličinu naselja, kojeg je Čović pretpostavio na oko 12 ha, teško je shvatljivo da se od svog pronalaska 1949. do 2007. godine ovaj lokalitet istraživao svega jednom. Potencijalni razlog tome može biti gusto naseljena površina na kojoj i danas ljudi žive na istom mjestu kao i prije oko 7.000 godina, ali kako 
se to može vidjeti na dronskim snimcima u prilogu rada, i dalje ima terena koji su slobodni za istraživanje.

Uvidom $\mathrm{u}$ dokumentaciju i cjelokupan asortiman keramičkih nalaza koji su deponovani $\mathrm{u}$ Zemaljskom muzeju u Sarajevu, sa ciljem pregleda materijala i stratigrafije koju je Čović ostavio iz
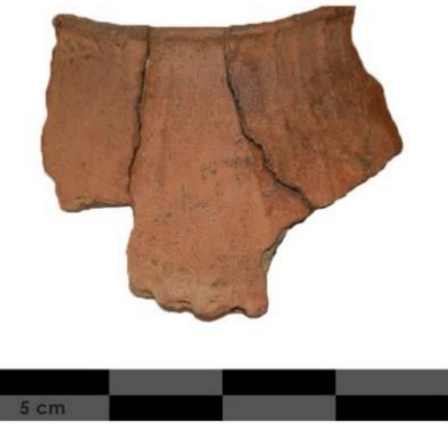
sebe, pokušat će se dati još jedna analiza iskopanog materijala. Prilikom analiziranja fine keramike, Čović je ustanovio da se nalazi neposredno na zdravici ipak u nekim crtama razlikuju od onih bližih stratumu V, pa je sloj VI podijelio na dva podstratuma, VIb i VIa. Faza VIb direktno se naslanja na zdravicu pri dubini od $5,45-5,15 \mathrm{~m}^{84}$

Slika 17. Barbotin posuda sa 5,45 m dubine, loptastog oblika i sa vertikalnim paralelnim trakama (snimio Dž. Brigić)

Najveći dio keramičkih nalaza iz ovog sloja predstavljaju fragmenti posuda debljih zidova, prosječne debljine 1-1,5 cm, uglavnom od slabije prečišćene gline bez dodavanja pijeska. Osnovne karakteristike starčevačke kulture jasno se izdvajaju o ovom sloju, pa se po načinu ukrašavanja vanjske površine primjećuju tri vrste: barbotin, impresso i urezana keramika. Ta keramika, zajedno sa monohromnom, koja ima manje ili više uglačanu površinu i slikanom keramikom predstavlja osnovu ovog stratuma. Najdominantija keramika ovog sloja je barbotin keramika, na koju je nakon modeliranaja suda na vanjskoj površini nabačen sloj razmućene zemlje koji je najčešće tretiran povlačenjem prstiju većinom vertikalno od oboda prema dnu posude, ${ }^{85}$ čime dolazi do formiranja paralelnih rebara (T. 2: 1). Pored toga, zabilježen je i barbotin ukrašen razbacanim grudicama zemlje koje su vjerovatno služile da veće posude učine grubljima radi lakše nosivosti, te bradavičasti naljepci poredani u pravilnom horizontalnom nizu koji su vjerovatno služili kao drške, što je bilo praktičnog karaktera $(\mathrm{T}, 2: 2,3)$.

Karakteristično za starčevačku kulturu, od oblika dominiraju jedostavni loptasti lonci i poluloptasti sudovi većih dimenzija. Posude su uglavnom rađene bez drški, izuzev malog broja primjeraka (Čović 1960-61: 83). U starijim fazama starčevačke kulture urezivanje je zastupljeno sa nekoliko motiva: okomitim urezima, urezanim paralelnim linijama koje oblikuju cik-cak motive, urezane mrežaste tanke linije. Na keramici Gornje Tuzle, u najdubljem stratumu VIb, zastupljena su svega dva fragmenta pronađena na dubini od $5,40 \mathrm{~m}$. Na jednom su od oboda vertikalno povučene paralelne

\footnotetext{
${ }^{84}$ Gruba keramika sačinjavala je u slojevima ove faze oko $50 \%$ od ukupnog keramičkog materijala.

${ }^{85}$ Zabilježeni su i motivi kosih ili izlomljenih cik-cak ukrasa, a horizontalne trake su prisutne na svega nekoliko fragmenata.
} 
oštro urezane linije, a na drugom identične oštro urezane paralelne linije koje idu do dna posude, ali već pri dnu prelaze u blago dijagonalni pravac (T. 2: 4, 5). Tehnika utiskivanja ili impresso (ukrašavanje štipanjem), koja se nanosila po cijeloj površini posude tako da se vrh prsta ili nokta utisnuo u vlažnu glinu, u Gornjoj Tuzli se javlja od najstarijih dubina. Već u sloju pri zdravici na dubini od 5,45 m pronađen je fragmenat narandžaste boje sa ravnim obodom ispod kojeg se, niz obod, javljaju vertikalno paralelni štipani ornamenti (T. 2: 6). Drugi fragmenat s iste dubine također ima dva paralelna, horizontalna ili vertikalna, pravca štipanja (T. 2: 7).

Slika 18. Horizontalni naljepci u obliku malih bradavica (snimio Dž. Brigić)

Pri dubini od 5,40 m pronađena su još tri gruba fragmenta ukrašena

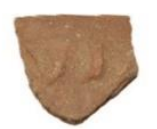
tehnikom štipanja te prvi fragmenat oboda ukrašen utiskivanjem prsta, što će se zadržati kroz sve slojeve Gornje Tuzle (T. 3: 1). Na dubini od 5,25 m pronađen je jedan malo veći fragmenat sivkaste boje na kojem je obod ukrašen utiskivanjem prsta a površina posude vertikalnim pravcima štipanja koji vjerovatno idu do kraja posude (T. 3: 2). Na prelazu iz VIb u VIa pri dubini od 5,15 m pronađena su još dva svjetlonarandžasta fragmenta ukrašena štipanjem po površini u pravilnim, vjerovatno vertikalnim pravcima (T. 3: 3), a na dubini od 5,03 m, koja pripada stratumu VIa, poluloptasti dio posude ukrašen razbacanim utiskivanjem nokta po trbuhu posude, što nije u ranijim slojevima zabilježeno (T. 3: 4). Pri ovoj dubini pronađen je i jedan tamniji fragmenat sa pravilno raspoređenom horizontalnom trakom ukrašenom utiskivanjem prsta, a na dubini od 5,00 m još jedan fragmenat posude sa obodom ukrašenim sa tri nivoa utisaka nokta u horizontalnom pravcu ispod oboda (T. 3: 5, 6). Prema tome, primjećuje se razlika u ornamentima impresso keramike (njeno opadanje) i različita ornamentika, što bi dalo još jednu osnovu za razdvajanje starčevačkog horizonta na dva različita sloja. ${ }^{86}$ Tehnika ukrašavanja plastičnim modeliranjem zastupljena je u Gornjoj Tuzli tek na dubini od $5,15 \mathrm{~m}$, gdje je pronađen jedan fragmenat sa plastičnom horizontalnom trakom ukrašenom utiskivanjem prsta. $\mathrm{Na}$ još jednom fragmentu, pri dubini od 5,00 m, primjećuju se horizontalni naljepci u obliku malih bradavica.

Faktura slikane keramike ne razlikuje se puno od grube, s tim da su manje posudice rađene od dobro prečišćene zemlje bez ikakvih primjesa. Slikanje je vršeno tamnom bojom bez sjaja, a boja se ne skida pri dodiru niti pod uticajem vode (Čović 1960-61). Najčešće su poluloptaste posudice, bez dosad konstatovanih drški. Na osnovu ovih karakteristika gornjotuzlanske keramike stratuma VI, Čoviću nije bilo teško ustanoviti srodnost sa starčevačkom grupom, ali je istakao evidentne razlike i

\footnotetext{
${ }^{86}$ Tehnika ubadanja nije zabilježena niti na jednom fragmentu posuda iz Gornje Tuzle.
} 
neke razlike u ornamentici slikane keramike. Naime, ornamentika gornjotuzlanske slikane keramike isključivo je pravolinijska, za razliku od krivolinijskog ukrašavanja u Starčevu (Garašanin 1954: 83). Uz pravolinijski ukras, čiji osnovni ornamentalni motiv predstavlja traka, detektovano je i nekoliko fragmenata sa geometrijskim ukrasom u obliku trougla, te jedan fragmenat sa cik-cak i meandrastim tekućim motivom (T. 4, 5, 6, 7, 8). Što se tiče monohromne keramike, nju karakteriše jednolični ton pečenja sa manje ili više uglačanom površinom, a najstariji nalazi sonde II-1958 pronađeni su među najdubljim slojevima starčevačke keramike. Osnovni oblik ove keramike predstavljaju poluloptaste posude na šupljoj nozi, kakve su nađene pri dubini od 5,45, 5,40 i 5,25 m, te poluloptaste posude sa ravnim dnom, a drške na ovakvim posudama su veoma rijetke, izuzev nekoliko fragmenata sa malim drškicama kroz koje se provlačilo uže ili snopovi pruća (T. 9: 1-4). Monohromnoj keramici pripadaju i pronađene noge najstarijih detektovanih žrtvenika iz Gornje Tuzle (T. 10).

Između najstarijeg i VIa stratuma ne primjećuje se kulturni prekid, ali se ipak od prethodne faze taj stratum razlikuje po određenim pojedinostima. Naime, slikana karemika je u naglom opadanju, kao što je to slučaj i sa impresso ornamentima, dok se razlike neposredno uočavaju unutar monohromne grupe gdje se javlja tendencija ka bikoničnom profilisanju posuda. Pronađen je svega jedan fragmenat crveno slikane keramike (polihromija) sa naopakim trouglastim motivima koji čine slovo $\mathrm{V}$, te jedan deblji fragmenat čija jedna polovica predstavlja barbotinom ukrašenu keramiku, a druga ima svjetliju bjelju podlogu na kojoj se primjećuju dva krivolinijska motiva koji podsjećaju na kružnu spiralu (T. 11). Barbotin je i dalje dominatna pojava na gruboj keramici uglavnom sa zaravnjenim ili zadebljanim obodom, ukrašenoj plastičnim horizontalnim trakama ispod oboda ili (na jednom fragmentu) dijagonalnim plastičnim motivima, ali se primjećuje pad impresso ornamenata. Osnovna razlika od VIb stratuma jeste faktura keramike, odnosno radi se o prvim nalazima keramike rađene sa znatnom primjesom sitnog kvarcnog pijeska ili kamene prašine, koja se u znatnoj mjeri razlikuje od nalaza iz starijih slojeva. Keramika je po pravilu bolje pečena, uglavnom tamnije smeđe i narandžaste boje, i njoj pripada ranije navedeni fragmenat tamnocrne posude ukrašene horizontalnim plastičnim trakama u tri reda (T. 12). Najveće razlike primjećuju se zapravo u monohromnoj keramici, gdje se prvi put javljaju bikonične forme posudica, kao i nova vrsta monohromne keramike čija je površina manje ili više glačana i obojena u crveno. Ona je u ovom stratumu zastupljena s tek nekoliko fragmenata, dok je dosta zastupljenija u mlađim slojevima (T. 13). U kulturnom pogledu, faza VIa predstavlja, dakle, nastavak Starčeva u Gornjoj Tuzli, gdje se primjećuju sporadične pojave mlađih elemenata koji će kasnije doći do izražaja. 


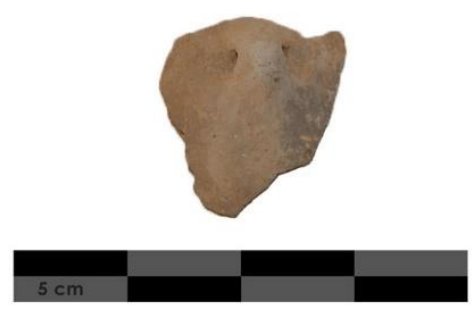

Slika 19. Fragmenat monohromne keramike sa malom drškom za provlačenje uzice, stratum IVb, dubina 5,15 m (snimio Dž. Brigić)

Također, Čović je ustanovio da ne postoji prekid života između sloja V i prethodnog stratuma, ali je ipak uvidio da se stratum $\mathrm{V}$ u kulturnom pogledu razlikuje i predstavlja novi razvoj. ${ }^{87}$ Najveća količina keramičkih predmeta

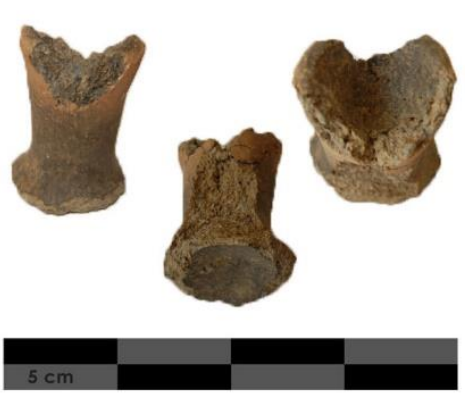
izrađena je od primjese veće količine sitnijeg i krupnijeg krečnog pijeska. Keramika ovog sloja pokazuje postepeno iščezavanje starih elemenata. Impresso keramika zastupljena je samo jednim fragmentom nađenim pri dubini od 4,32 m, ukrašenim horizontalnom plastičnom trakom utiskivanjem prstima. Barbotin, slikana i starija monohromna keramika, zastupljena jednom niskom čepastom nogom žrtvenika nađenog na dubini od 4,85 m, gotovo u potpunosti izlaze iz upotrebe (T. 14: 1, 2). U nižim nivoima stratuma $\mathrm{V}$ pronađene su posude sa šupljim cilindričnim nogama raznih oblika, koje su srodne monohromnoj keramici. ${ }^{88}$ Prisutne su vitke šuplje noge, stubaste noge sa uskom rupom u sredini, pune visoke cilindrične noge sa malim udubljenjem, gdje je na drugima bila šupljina (T. 15). Ne zna se tačno kojem obliku posude pripadaju, ali prema ostalim nalazima srodne fakture moguće da su to obične konične zdjele na visokoj nozi. Najveći dio fragmenata ovog stratuma pripada običnim velikim koničnim posudama sa uskim dnom, istanjenog oboda ukrašenog utiskivanjem prstiju, sa bradavičastim drškama. Zastupljene su i nešto pliće posude sa uvučenim zadebljanim obodom, ukrašene također utiskivanjem prsta.

Prvi puta na lokalitetu Gornja Tuzla u ovom stratum javljaju se (kasnije mnogobrojne) pune grube noge posuda od kojih se mogu izdvojiti tri tipa: stubaste noge sa proširenom bazom, stubaste

\footnotetext{
${ }^{87}$ Debljina ovog stratuma u sondi II-1958 iznosi u prosjeku nešto ispod 0,70 m. Od prethodnog stratuma se ne odvaja po boji, nego ima drugačiju tvrdoću i obojenje profila zbog većeg prisustva keramike (Čović 1960-61: 88).

${ }^{88}$ Kao izuzetak, konstatovana je jedna noga koja podsjeća na nogu vinčanskog pehara.
} 
masivne noge koje se pri gornjem dijelu šire u recipijent te konične prema dole sužene noge. Od drški najzastupljenije su bradavičaste drške, zatim plastična ispupčenja te male horizontalno postavljene ušice (T. 16).

Posebnu keramičku grupu čine fragmenti uglavnom malih bikoničnih posudica tamnosive, sivosmeđe ili crne keramike koja je relativno dobro glačana i najčešće ukrašena kanelurama, i koja se češće pojavljuje u mlađim sedimentima stratuma, što je Čović identificirao kao prve znakove pojavljivanja vinčanske kulture na ovom lokalitetu (Čović 1960-61: 92). Fina monohromna keramika sa bojenom prevlakom, koja se postepno počela pojavljivati u prethodnom stratumu, sada doživljava puni razvoj i predstavlja jednu od karakteristika ovog stratuma.

Slika 20. Stubaste noge sa proširenom bazom (snimio Dž. Brigić)

Najveći broj fragmenata ove keramike najvjerovatnije pripada jednostavnim poluloptastim posudicama malih dimenzija, s istanjenim obodima bez konstatovanih drški, ali zbog nešto manjih fragmenata teško je sa sigurnošću odrediti oblik (T. 17, 18, 19, 20). Najveća koncentracija fine bojene monohromne keramike zastupljena je u dubljim sedimentima stratuma $\mathrm{V}$, dok se prema narednom stratumu postepeno umanjuje, što je još jedan pokazatelj promjena koje su se desile u ovom periodu života. Srodna keramika sa crvenom prevlakom ${ }^{89}$ javlja se u Vinči i traje kroz starije slojeve, na osnovu čega je Čović ustvrdio da ova keramika, kako u Vinči tako i u Gornjoj Tuzli, predstavlja produženje starčevačke tradicije unutar nove nadolazeće vinčanske kulturne grupe (Čović 1960-61: 91). Primjerci sive i crne glačane keramike sa kanelurama ipak su dosta značajniji u hronološkom, ali i kulturnom pogledu (T. 22), jer prema fakturi, oblicima i načinu ornamentacije pružaju direktnu analogiju sa starijim vinčanskim slojevima (Čović 1960-61: 114). Na osnovu navedenog mogla bi se povući paralela da su stratum V Gornje Tuzle i prva faza vinčansko-tordoške kulture hronološki istovremeni (Garašanin 1951: 18). To bi značilo da sa stratumom V Gornje Tuzle otpočinje novi način života koji svoje začetke jednim dijelom vuče iz stratuma VIa, ali koji pokazuje nove elemente neke druge populacije, u ovom slučaju vinčanske.

Sedimenti narednog stratuma IV, čija debljina iznosi oko $0,50 \mathrm{~m}$, ne razlikuju se ni prema sastavu niti prema boji od gornjih sedimenata stratuma V. Zanimljivo je da se prema gornjim slojevima, odnosno prema stratumu III, postepeno stvara tvrđi sloj gotovo u potpunosti bez životinjskih kostiju koji, prema Čovićevom mišljenju, ne predstavlja sterilni sloj koji bi činio stratigrafsku granicu između stratuma IV i III naselja u Gornjoj Tuzli (Čović 1960-61: 93). Na osnovu sprovedene analize

\footnotetext{
${ }^{89}$ Nekada je prevlaka intenzivno glačana i sjajna, što je naročito slučaj u starijim slojevima čiji materijalni ostaci odgovaraju primjercima vinčansko-tordoške faze (Garašanin 1951: 19). Vasić smatra da je ona nanošena na površinu suda i zatim glačana (Vasić 1936a: 122).
} 
kulturnih ostataka stratuma III, Čović je uvidio kontinuirano produženje života i kulturnog razvoja u naselju. ${ }^{90}$ Specifikum ovog stratuma jeste potpuni nedostatak stare keramičke vrste koja bi svoj korijen vukla iz stratuma VI, kao što je to slučaj u prethodnom stratumu V. ${ }^{11}$ Osnovnu karakteristiku ovog stratuma činila bi gruba keramika rađena sa velikom primjesom pijeska, među kojom dominiraju posude sa zadebljanim uvučenim bikoničnim obodom, ukrašenim širim otiskom prsta, koje najvjerovatnije predstavljaju plitke široke posude (T. 23), ali s obzirom na slabije keramičke nalaze ovog stratuma teško je to konkretnije odrediti. Utvrđeno je i postojanje posuda sa ravnim obodom koji nije ukrašen utiskivanjem prstiju, ali se ispod njega nalaze horizontalne kanelure kakve su postojale na barbotin keramici (T. 24), što će se manje-više zadržati kroz sve slojeve Gornje Tuzle. Od drški potrebno je izdvojiti manje trakaste drške, zabilježene u nekoliko fragmenata na kojima se ne nazire obod ni neki drugi važniji dio posude.

Slika 21. Dno posude stratuma IV sa otiskom asure (snimio Dž. Brigić)

Nalazi grubih nogu i dalje su zastupljeni, ali sada se kao dominantan oblik javljaju konične prema dole sužene noge koje su vjerovatno zabadane u zemlju ( $\mathrm{T}$. 25). Fina keramika zastupljena je u svega nekoliko manjih fragmenata tipične vinčanske crne ili sive polirane robe ukrašene kanelurama. Detektovana su dva oblika koji će biti karakteristični kasnije u stratumu III, a to su mala posuda sa širokim izvijenim vratom ukrašena kanelurama sa obje strane i dno posude ukrašeno otiskom asure.

U stratumu IV primjećuje se, dakle, iščezavanje starčevačkih elemenata u korist vinčanskih koji sada već preovladavaju, ali upotreba lokalne domaće crvenkaste grube keramike (kakva se i danas vidi na površini lokaliteta), rađene sa velikom primjesom krečnog pijeska, utvrđuje kontinuitet i vezu sa starijim slojevima. Prema tome, stratum IV naselja u Gornjoj Tuzli bi, na osnovu analize materijala, odgovarao sloju III i prelaznom III/II sloju naselja Varoš kod Koraja.

Prema Bencu, ti stratumi u Varoši hronološki bi odgovarali mlađoj vinčansko-tordoškoj fazi (Benac 1960-61: 62), što bi stratum IV Gornje Tuzle hronološki smjestilo na kraj vinčansko-tordoške faze, ${ }^{92}$

\footnotetext{
90 S obzirom na "siromaštvo" nalaza iz IV. sloja, Čović pretpostavlja da su se na mjestu zahvaćenom sondom slojevi ovog stratuma formirali na nekoj praznini između kuća ili grupa kuća u naselju. U prilog tome govorio bi i potpuni nedostatak fragmenata lijepa u ovim slojevima, te gotovo potpuni nedostatak kamenog ili koštanog oruđa (Čović 196061: 93).

${ }^{91}$ Isto tako u potpunosti je nestala i fina monohromna keramika sa bojenom prevlakom koja, kao što se moglo primijetiti ranije, čini bitniju karakteristiku prethodnog stratuma V.

92 Prema Garašaninu Vinča-Tordoš II (Garašanin 1954: 108), a prema Milojčiću Vinča B 2 (Milojčić 1949: 72).
} 
o čemu govori i Garašanin u svom radu o mlađem neolitu Bosne i Srbije (Garašanin 1954: 9). Na osnovu hronološke slike i unutrašnjih promjena koje karakterišu stratum IV, Čović iznosi pretpostavku da je u periodu formiranja sedimenata stratuma IV došlo do preloma u kulturnom smislu(Čović 1960-61: 116). ${ }^{93}$

Ove dvije kategorije kontinuiteta mogu se i dodirivati, ali isto tako mogu biti u potpunosti odvojene ukoliko bi postojao kulturni kontinuitet. Prema Vladimiru Lekoviću, fenomen kontinuiteta, posmatrano iz arheološke perspektive, može biti ustanovljen jedino kroz jasne i očite dobro definisane arheološke nalaze (Leković 1990: 70). Čovićev zaključak mogao bi biti točan, posebno ukoliko se uzmu u obzir gornji slojevi koji su izrazito vinčanskog karaktera, uz fragmente crvenkaste domaće "starčevačke" keramike koja se zadržala dugo vremena. Teorija o tome da su vinčanski elementi nenasilno preuzeli dominaciju unutar jednog naselja u svakom slučaju nailazi na potporu u Gornjoj Tuzli.

Stratum III naselja u Gornjoj Tuzli u potpunosti predstavlja elemente vinčanske kulture u kojoj fina siva i crna glačana keramika dolaze do kulminacije. Osnovni ornamentalni motiv ovog stratuma, zajedno sa koničnim ili izduženim ispupčenjima, jesu zapravo kanelure koje, kao što je već poznato, predstavljaju osnovni ornament vinčanske kulture (Vasić 1932: 26). Osnovne karakteristike stratuma III, kada je u pitanju keramika, jesu zapravo gruba crvenkasta, gruba sivocrna polirana i fina glačana keramika, koje po svojoj fakturi odgovaraju vinčanskim proizvodima. Gruba crvenkasta keramika zastupljena je, prema pregledu materijala, u nešto više od polovine ukupnih nalaza iz ovog stratuma i predstavlja keramiku koja se u Gornjoj Tuzli javlja još od stratuma V. Razlika je svakako u kvaliteti: u ovom se stratumu ističe manja upotreba pijeska, što automatski olakšava proizvodnju ravnijih posuda, kao i sam proces relativnog glačanja koje je sada prisutno sa obje strane posude. Posude sa zadebljanim bikoničnim obodom ukrašene utiskivanjem prstima veoma se rjeđe javljaju, dok do punog izražaja dolaze veće posude sa šiljatim dnom, odnosno koničnim prema dole suženim šupljim nogama nešto većih dimenzija koje se prema sredini posude šire u jednom sastavu (T. 26). Ove posude morale su biti zabadane u zemlju ili na neko drugo mjesto zbog stabilnosti, ali i činjenice da na njima nisu pronađene drške, i vjerovatno su se koristile za pohranjivanje veće količine namirnica. Drugi karakterističan oblik grube crvenkaste keramike predstavlja trbušasti sud sa izvraćenim obodom (T. 27), na kojemu su pronađene manje trakaste drške, a ponekad i bradavičasta plastična ispučenja. Od ukrasa, na obje posude zabilježeni su standarni ukrasi na gruboj keramici, udubljenja prstom ispod oboda ili plastične trake sa udubljenim prstima ili noktima. Svi ovi ukrasi vuku

${ }^{93}$ Fenomen kontinuiteta u arheologiji u suštini se može shvatiti kao kulturni i “etnički” kontinuitet (Garašanin 1964: 69). 
tradiciju iz ranijih starčevačkih slojeva, što predstavlja značajnu karakteristiku Gornje Tuzle. Potrebno je izdvojiti i male konične posude, kao i jedan fragmenat sa kljunom za izlivanje tečnosti.

Novinu među materijalom Gornje Tuzle predstavlja gruba sivo-crna keramika koja je u ovom stratumu zastupljena u oko $10 \%$ fragmenata. Ona je bolje pečena i rađena sa manjom primjesom krečnog ili kvarcnog pijeska. Sudeći prema nalazima, utvrđeno je postojanje samo jedne vrste posude grube sivo-crne keramike, a to je duboka trbušasta posuda sa izvraćenim obodom i trakastim dršakama smještenim na sredini suda. Na nekoliko mjesta uočena su plastična ispupčenja i kratki nizovi ureza ispod oboda (T. 28), a ranija pojava otiska asure na dnu čini značajniju karatkeristiku ovih posuda (T. 29). Od fine keramike potrebno je istaknuti zdjele manjih dimenzija sa uvučenim obodom, koje su relativno dobro uglačane; zatim, zdjele sa cilindričnim vratom i ojačanim ramenom, velike zdjele sa ojačanim ramenom i široko izvijenim vratom, te duboke zdjele sa prema gore suženim vratom koje karakterišu četiri ispupčenja na centralnom dijelu posude, što svakako predstavlja novinu u Gornjoj Tuzli. Naime, ispupčenja sad nisu dodavana kao ranije, nego su izvlačena tokom modeliranja posude, iz čega se može izvući podatak o značajnom napretku keramografije. Posljednji oblik koji pripada stratumu III, a koji se zadržava i kroz stratum II, jesu amfore sa relativno uskim cilindričnim vratom i malim ušicama kao drškama za provlačenje uzice (T. 30, 1-5). Osnovni ornament na finoj keramiki iz stratuma III jesu kanelure koje se uglavnom nalaze na vratu, ramenu ili trbuhu posuda, a kreću se u horizontalnom, dijagonalnom i vertikalnom pravcu. Potrebno je izdvojiti i posudice sa urezanim linijama na dnu ili donjem dijelu, ornamentom koji predstavlja neke vrste znaka odnosno ravnu liniju koja se grana u tri pravca. ${ }^{94}$

Čović je nakon analize utvrdio da sloj III u Gornjoj Tuzli u kulturnom pogledu pripada vinčanskoj grupi vežući se hronološki približno za slojeve između šestog i četvrtog metra u Vinči. ${ }^{95}$ No, kada je u pitanju stratum III Gornje Tuzle dubine između 3,75 i 2,90 m, najzanimljiviji nalazi u svakom slučaju jesu tri fragmenta nekog oruđa za koje Čović kaže da izgleda kao koštano šilo, izrađenog od bakarne žice. Značajan nalaz predstavlja i nakit od bakra: 22 male bakarne perle nađene na istom mjestu, pored ugljenisane grede, na dubini od 3,50 m, zatim 13 malih perli nađenih na dubini od 3,20 m, spiralni prsten od bakarne žice nađen na dubini od 3,05 m, te fragment tanke bakarne žice

\footnotetext{
94 Sličan nalaz pronađen je u sondi I-2018.

95 Treba, međutim, imati u vidu da između ova dva nalazišta postoje i određene razlike u keramografiji koje su uglavnom uslovljene geografskim položajem naselja u Gornjoj Tuzli te složenim procesom kulturnih promjena koje su se u njemu odigravale. Na osnovu toga, kao i nekih drugih znatnijih i neznatnijih razlika na keramici i plastici, Čović objašnjava razliku između Gornje Tuzle u ovom periodu i ostalih poznatih naselja vinčansko-pločničke faze (Čović 1960-61: 118).
} 
okruglog presjeka, koja je vjerovatno bila dio narukvice (T. 31). ${ }^{96}$ U blizini jednog od ognjišta pronađenog u sondi, na nekoliko mjesta nađeno je bakarnih oksida odnosno oksidiranih kapljica ili sitnih otpadaka bakra, što bi asociralo na mogućnost da se tu nalazio prostor posvećen obradi ovog metala. Veoma dugi niz godina smatralo se kako je metalurgija vinčanske kulture zastupljena samo u njezinim mlađim periodima, ali dugogodišnjim istraživanjima ustanovljeno je kako su vinčanci tokom cijelog svog postojanja poznavali metalurgiju u različitim razvojnim stepenima (Antonović 2002: 27; 2009: 166). Tome svjedoče i nalazi iz Gornje Tuzle, kao i mnogobrojni pronađeni bakarni oksidi i troske, koje su ucrtane u milimetarski dnevnik sa iskopavanja iz 1958. godine. Prema tome, vinčanska kultura je savremenik početka jednog novog razvoja, tokom kojeg se, od jedne vrste kamena počinju izrađivati metalni proizvodi - barem kako su to vjerovatno shvatali u najranijim
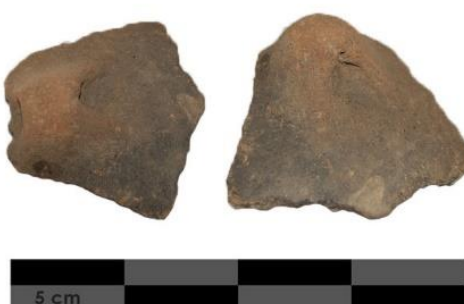
vremenima (Burić 2014: 51).

Slika 22. Dekorativne drške na keramici stratuma II (snimio Dž. Brigić)

Stratum III počinje na dubini $3,75 \mathrm{~m}$ i zajedno sa stratumom II predstavlja razvoj života i svakodnevnih aktivnosti stanovnika ovog naselja, što bi za posljedicu imalo formiranje tri metra debelog kulturnog sloja koji bi pripadao vinčanskoj grupi. Na osnovu rezultata analize kulturnog inventara, primjećuje se kontinuiran razvoj sa ipak uočljivim laganim prelazima i sporom zamjenom ranijih oblika novijima, što je dovelo do toga da Čović ovaj debeli sloj razdvoji na dva stratuma. Keramika se i dalje dijeli na grubu crvenkastu, grubu sivo-crnu i finu glačanu. Kod grube crvenkaste keramike, ranije definisane posude sa šiljatim dnom i trbušaste sa izvraćenim obodom i dalje se zadržavaju, ali dolazi do određenih promjena koje se protežu do mlađih slojeva, odnosno šiljata dna sada iz sloja u sloj postaju zdepastija i manja (T. 32, 1-3), ${ }^{97}$ dok trbušaste posude ostaju iste osim što plastične drške postaju češće. Nove oblike grubih posuda stratuma II čine zdjele sa kljunom za izlivanje, od kojih je jedan takav obod detektovan u stratumu III, zatim plitke posude sa bradavičastim drškama na obodu, što ranije nije determinisano (T. 33), plitki tanjiri odnosno veoma plitke posudice sa neznatnim prelazom dna $\mathrm{u}$ zidove, a kod grube sivo-crne keramike posude na veoma širokoj cilindričnoj nozi i nešto dublje posude sa uvučenim obodom (T. 34, 1-3).

\footnotetext{
96 Danas je lokacija bakarnih objekata nepoznata s obzirom na to da se zgrada muzeja nekoliko puta premještala tokom druge polovice 20. st., kao i nakon rata koji je zadesio Bosnu 90-ih godina, pa se izgubio trag ovom najznačajnijem nalazu metala na prostoru Gornje Tuzle.

97 Posude sa šiljatim dnom zadržavaju se do dubine od 2,10 m, kada se pojavljuju manje posude na kojima šiljata dna postaju zdepastija.
} 
Kroz cijeli stratum II dominira gruba crvenkasta keramika sa osnovnim oblikom posuda sa šiljatim ili zdepastijim dnom, a njen procenat zapravo raste prema plićim slojevima (Čović 1960-61: 100) odnosno završnim fazama vinčanske kulture u Gornjoj Tuzli. Kod finije glačane robe dolazi do niza promjena, koje i opravdavaju izdvajanje sloja između 2,90 i 0,90 m u poseban kulturni stratum. Zdjele sa cilindričnim vratom, zatim zdjele sa široko izvijenim vratom te duboke zdjele sa vratom koji se prema gore sužava, koje su bile karakteristične za stratum III, sada se gotovo nikako ne pojavljuju. Najzastupljeniji oblici fine keramike stratuma II jesu zdjele raznih dimenzija sa uvučenim obodom (T. 35), zaobljene poluloptaste zdjele sa kratkim širokim vratom (T. 36) i poluloptaste šolje na kojima se ne ističe dno (T. 37). Bitnu karakteristiku ovog stratuma predstavljaju posude na višoj ili nižoj šupljoj nozi, a od nogu su zastupljena tri oblika: cilindrične šuplje noge većih dimenzija, zvonolike noge i veoma rijetko visoke šuplje noge koje se prema gore sužavaju (T. 38). ${ }^{98}$ Pored oblika posuda, na finoj keramici dolazi i do razvoja drški. ${ }^{99}$ Kod dubljih posuda one su postavljene tako da spajaju vrat i rame, a zastupljene su i tunelasta drška manjih dimenzija kroz koju se provlačila uzica, trakasta i bradavičasta drška (T. 39 i 40). Posebno treba istaknuti dekorativne drške kakve se sporadično pojavljuju u stratumu III, a nešto više u stratumu II, koje zapravo nemaju nikakvu funkciju osim ukrasne, jer nisu probušene i premalih su dimenzija da bi se posuda puna hrane ili vode mogla za njih uhvatiti i prenositi. Međutim, veoma bitnu promjenu označava potpuna degeneracija kanelura, koje su zamijenjene rijetkim nalazima širih

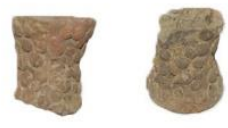
razmaknutih paralelnih linija. Jedini oblik na kojem su se kanelure zadržale jesu zdjele sa uvučenim obodom, ali se kanelure pojavljuju samo na obodu.

Slika 23. Noga ukrašena plastičnim naljepcima (snimio Dž. Brigić)

Zanimljivo je da se plastična ispupčenja zadržavaju do kraja stratuma II, posebno na zdjelama sa uvučenim obodom. Čović navodi i jedan izuzetak u ornamentici, pronađen u ovom stratumu, a dodatno potvrđen uvidom u materijal, a to je mala noga sa proširenom bazom, čija je cjelokupna površina prekrivena pravilno poredanim plastičnim naljepcima.

Pregledom keramike koja pripada ovom stratumu može se uvidjeti da ona postepeno popušta $u$ kvaliteti izrade, odnosno da kvalitet izrade posuda opada idući iz dubljih prema plićim sedimentima stratuma II gdje se više ne primjećuje glačanje do sjaja, a Čović ističe i pronalazak jednog fragmenta pri dubini od 1,90 m u čijoj je primjesi uočena pljeva. Očigledno je da se vinčanska kultura u

\footnotetext{
98 Ovaj oblik nogu veoma je čest u Varoši kod Koraja (Benac 1960-61: 79).

${ }^{99}$ Izuzetak predstavlja jedna drška u obliku falosa čiji vrh se produžuje nekoliko centimetara.
} 
Gornjoj Tuzli zadržala duži period tokom kojeg se keramika može pratiti od njene najkvalitetnije do manje kvalitetnije izrade.

U hronološkom pogledu, s obzirom na Čovićevu paralelu stratuma III sa dubinom između 6 i $4 \mathrm{~m} \mathrm{u}$ Vinči, stratum II u Gornjoj Tuzli pripadao bi završnoj fazi vinčanske kulture u cjelini. U stratumu II se u znatnijoj mjeri nego u prethodnom stratumu mogu zapaziti elementi strani vinčanskoj kulturi, poput šupljih nogu s otvorima, koji s druge strane predstavljaju jednu od karakteristika lengyelske kulture (Korošec 1957: 175) koja je svoj uticaj na sjevernu Bosnu imala krajem mlađeg neolita na Balkanu. Također, u naselju Varoš kod Koraja, čiji stratum I predstavlja paralelu stratumu II Gornje Tuzle, primjećuju se strani elementi koje Benac tumači uticajima sa sjevera (Benac 1960-61: 56).

Posljednjem, najgornjem stratumu koji je Čović označio kao stratum I pripadaju najmlađi prahistorijski slojevi naselja u Gornjoj Tuzli, dakle na dubini od 0,90 do 0,40 m, od čega bi ostatak otpadao na humus. Stratum I se u kulturnom pogledu u potpunosti odvaja od prethodnog, kojeg karateriše prisustvo velike količine crvenkaste keramike koja mu daje obojenje u profilu i tvrdoću zemlje, nasuprot relativno mekom i rastresitom sloju uglavnom tamnosmeđe ili crne boje stratuma I. Ono što karakteriše ovaj stratum jeste pojava čitavog niza novih elemenata koji nemaju nikakvih prethodnika u ranijim slojevima (T. 41, 42). Između ostalog, potrebno je izdvojiti finu crnu keramiku čija je površina dobro glačana ali bez sjaja, rađenu bez ikakve pješčane primjese, čije su i vanjska i unutrašnja stijenka crne, što se vidi i na prelomu koji je crne ili tamnosive boje. Najveći dio pripada keramici čija površina nikada nije gruba, a nerijetko je polirana i do glačanja bez sjaja, crvenkastosmeđeg do žutosmeđeg obojenja. Oblici posuda su raznovrsni, odnosno ustanovljene su poluloptaste ili jajaste posude, zatim posude sa konkavno uvijenim vratom, posude sa jače izvraćenim obodom, zaobljene zdjele sa izvraćenim zaravnjenim obodom, visoki lončići sa drškama koje polaze od oboda, kao i male kupe grubih kontura, sa proširenom bazom. Najbrojnije su vertikalne trakaste drške i dosta rjeđe tunelaste drške. Također, u većem dijelu stratuma I nisu zabilježeni ornamenti, ali su se mogli primijetiti urezi ili udubljenja na obodima ili ramenu posuda, dok su na crnoj glačanoj keramici uočeni snopovi kosih udubljenih linija od ramena do trbuha posude, nizovi trouglastih udubljenja ispod oboda i mrežasti ornamenati. Izuzetak predstavljaju ornamenti izvedeni ispod oboda cik-cak motivom kosim ubodima nekog oštrog oruđa, zatim plitke kose kanelure na gornjem dijelu jedne drške i ornament radijalnih traka izvedenih dvostrukim ubodima (Čović 1960-61: 106).

Najgornji slojevi naselja u Gornjoj Tuzli, prema Čoviću, pripadaju periodu ranog eneolita kada se ostvaruju kulturne i hronološke paralele sa naseljima poput Lengyela i Bubnja, jer se ornamenti koji 
se pojavljuju na keramici stratuma I (snopovi udubljenih ili urezanih linija te šrafirani ili mrežom ispunjeni trouglovi) vežu za mlađi Bubanj, odnosno Bubanj-Hum II. ${ }^{100}$ Posljednji sloj Gornje Tuzle Čović hronološki veže za badensku kulturu (Čović 1960-61: 126), posebno ako se uzme u obzir postojanje kratkotrajnog sloja badenske i kostolačke kulture na prostoru sjeveroistočne Bosne (Benac 1962: 21). U svakom slučaju, ono što je najvažnije za stratum I Gornje Tuzle jeste činjenica da on pripada jednoj novoj grupi stanovništva koja se naselila na ove prostore možda nakon uništavanja ili napuštanja vinčanskog naselja.

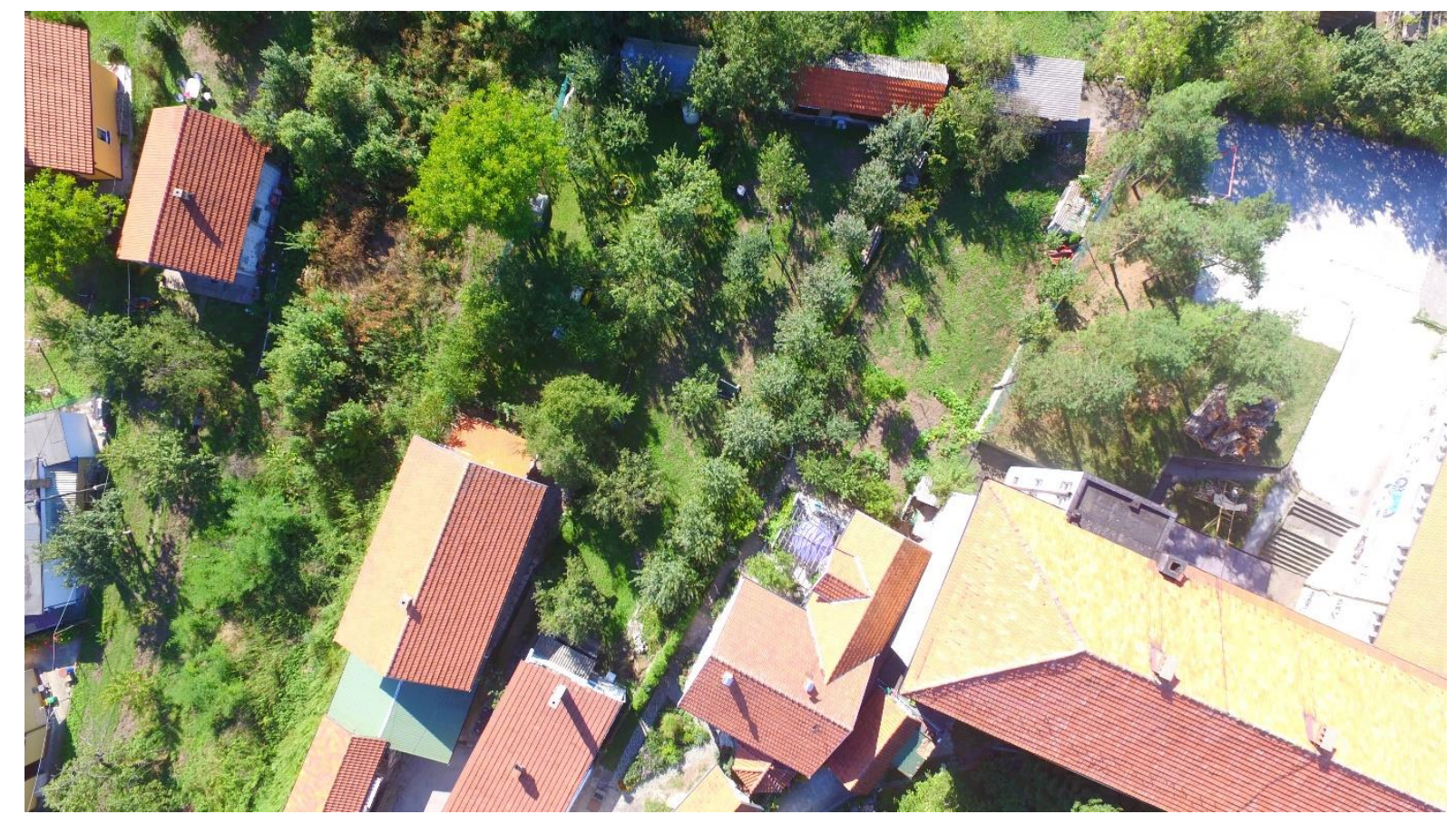

Slika 24. Lokacija sonde II-1958 (snimio M. Burić)

\footnotetext{
${ }^{100}$ U mlađim bubanjskim slojevima koji pripadaju fazi Bubanj-Hum II i naročito III, zastupljene su drške koje po svojoj profilaciji i mjestu na posudi potpuno odgovaraju nekim primjercima iz Gornje Tuzle (Čović 1960-61: 123).
} 


\section{4c Rezultati najnovijih istraživanja}

Nakon skoro 50 godina terenske stagnacije na lokalitetu Gornja Tuzla, godine 2007. pokrenut je istraživački projekat pod pokroviteljstvom JU Muzej Istočne Bosne Tuzla, koji je predvodila Zilka Kujundžić-Vejzagić, arheologinja i muzejska savjetnica Zemaljskog muzeja Bosne i Hercegovine u Sarajevu u saradnji sa Prahistorijskim institutom iz Beča koji su zastupali Andreas Lippert i Georg Tiefengraber. Pored navedenih, članove stručnog tima činili su Mirsad Bakalović (kustos arheolog JU Muzej Istočne Bosne Tuzla), Nataša Perić (kustos historičar JU Muzej Istočne Bosne Tuzla) i Ljiljana Jevtić (kustos arheolog- pripravnik Zemaljskog muzeja Bosne i Hercegovine u Sarajevu). Fizičke poslove obavljala su tri fizička radnika iz Gornje Tuzle, a jedan je čuvao lokalitet preko noći. Prema dokumentu poslatom Ministarstvu obrazovanja, nauke, kulture i sporta Vlade Tuzlanskog kantona 4. aprila 2008. godine, u kojem se obrazlaže lokalitet Gornja Tuzla, navode se ciljevi istraživanja, odnosno želja da se upotpuni saznanje o materijalnoj i duhovnoj kulturi stanovnika iz doba ranog neolita, kao i o kontinuitetu naselja u Gornoj Tuzli i vezama sa okolnim naseljima. Dalje se ističe kako istraživanje ovog lokaliteta obuhvata sondažno- zaštitno iskopavanje, kabinetsku i laboratorijsku obradu terenske dokumentacije i otkrivenog arheološkog materijala, muzeološku obradu nalaza, kao i analizu rezultata istraživanja i njihovo publikovanje. Izuzev radiokarbonske analize nalaza gari i kostiju, ništa od navedenog nije ispunjeno s ozbirom na stanje pokretnih nalaza od kojih dosta toga još uvijek nije ni oprano, a kamoli obrađeno.

Tokom probnog istraživanja 2007. godine, otvorena je sonda I i tom je prilikom otkriveno dosta fragmenata grube i nešto manje fragmenata glačane keramike, prvenstveno fragmenti posuda za isoljavanje slane vode, kao i nešto kremenog i koštanog oruđa i oružja. Pronađeni materijal pripisan je vinčanskoj kulturnoj grupi, a otkriveni su još i ostaci kalotne peći koja je, prema izvještaju dostavljenom u Muzej Istočne Bosne u Tuzli, služila za pečenje keramičkog posuđa (T. 43). ${ }^{101}$ Njena lokacija je oko 10-15 m sjeveroistočno u odnosu na spomenuti Društveni dom i nalazi se na posjedu koji pripada geologu Safetu (k.č. 615), pa se ujedno i naziva "Safetova bašča". Nalazi se malo ispod sredine tela i predstavlja izuzetno dobru lokaciju za nova potencijalna istraživanja. Tačne koordinate navode se u izvještaju:

\footnotetext{
101 Izvještaj sa arheološkog iskopavanja na lokalitetu neolitskog naselja u Gornjoj Tuzli 14.07.-19.07. 2008. godine (04155/08), 22. 7. 2008. godine (Bakalović 2008a: 1).
} 
Tabela 4. Spisak koordinata i kota krajnjih tačaka Sonde I (Safetova bašča) u Gornjoj Tuzli

\begin{tabular}{|c|c|c|c|c|}
\hline $\begin{array}{c}\text { Redni } \\
\text { broj }\end{array}$ & Ordinata Y & Apscisa & $\begin{array}{c}\text { Nadmorska visina } \\
\mathrm{H}\end{array}$ & Položajni opis \\
\hline 1 & 6560857,34 & 4934924,01 & 318,48 & U Safetovoj bašči \\
\hline 2 & 6560860,23 & 4934924,09 & 318,32 & U Safetovoj bašči \\
\hline 3 & 65608060,25 & 4934919,00 & 318,04 & U Safetovoj bašči \\
\hline 4 & 6560857,30 & 4934919,04 & 318,16 & U Safetovoj bašči \\
\hline
\end{tabular}

Tabela 5. Spisak koordinata i kota repera u Gornjoj Tuzli, lokalitet: Sonda I/2007

\begin{tabular}{|c|c|c|c|c|}
\hline $\begin{array}{c}\text { Redni } \\
\text { broj }\end{array}$ & Ordinata Y & Apscisa & $\begin{array}{c}\text { Nadmorska visina } \\
\mathrm{H}\end{array}$ & Položajni opis \\
\hline R-1 & 6560870,86 & 4934923,12 & 319,243 & Na crvenom stubu \\
\hline R-2 & 6560837,47 & 4934886,25 & 318,318 & $\begin{array}{c}\text { Na ogradi Doma } \\
\text { kulture }\end{array}$ \\
\hline R-3 & 6560839,88 & 4934898,37 & 319,321 & $\begin{array}{c}\text { Na ogradi Doma } \\
\text { kulture }\end{array}$ \\
\hline
\end{tabular}

Nažalost, kada je u pitanju sonda I-2007, u navedenom izvještaju više se ništa ne navodi osim njene lokacije u odnosu na poziciju Društvenog doma u Gornjoj Tuzli. Zahvaljujući veoma teškom procesu pronalaska izvještaja sa iskopavanja provedenog u Gornjoj Tuzli, upućen je zahtjev Prahistorijskom institutu u Beču da dostavi sve dokumente koje ima, a da su vezani za sprovedeno istraživanje. Na taj se način došlo do dva CD-a na kojima su pronađene slike iz sonde I, pa se ona barem okvirno mogla pozicionirati. Na osnovu fotografija moglo se zaključiti kako sonda nije završena do kraja, ali obim keramike u depou Muzeja Istočne Bosne u Tuzli izgledao je preveliki, da bi se kasnije, internom 
preraspodjelom muzeja i spletom okolnosti, pronašao cjelokupan izvještaj iz kojega se vidi kako su otvorene četiri sonde, a radovi na sondi I nastavljeni od 8. juna do 19. jula 2008. godine. Sonda I je, dakle, prema izvještaju zamišljena kao probna sonda i jedina je otvorena 2007. godine sa ciljem da se kroz dvije godine ponovo otvori, za kada je planirano višegodišnje sistematsko istraživanje. Radovi su nastavljeni 2008. godine, kako se navodi u izvještaju iz iste godine, primjećuje se da su pokretni nalazi u muzeju odvojeni na nalaze iz 2007. i 2009. godine te da nalaza iskopanih u 2008. godini nema, ili te godine nije ni vršeno iskopavanje. S obzirom na izvještaj od 22. jula 2008. godine, svega nekoliko dana nakon terenskog istraživanja i s obzirom na identične prve pasuse u izvještajima iz 2008. i 2009. godine, moguće je da su tokom ove godine otvorene ostale tri sonde, a radovi na sondi I nastavljeni iduće 2009. godine. Ukoliko se tako odvila situacija, kako i pokazuju signature nalaza, onda u ovom trenutku nedostaje finalni izvještaj sa iskopavanja iz 2009. godine.

Prema izvještaju iz 2008. godine, sonda I nije iskopana do kraja (otkopano je 18 otkopnih slojeva), ali se navodi da je otvoren kontrolni rov uz istočni profil sonde, koji je spušten do zdravice na dubini od 2,70 m. Najzanimljiviji nalaz koji je dobio nešto veću pažnju u medijima jeste figurina ženskog lika, pronađena u šutu. ${ }^{102}$ Pored navedene figurine, pronađena je još jedna figurina sa glavom u obliku ptice, ali se zbog manjka informacija o mjestu pronalaska ne može smjestiti u kontekst. Važno je istaći i nalaze dvije kamene kalupaste sjekire, veoma dobro polirane, te dva žrvnja i četiri kamene kugle veličine teniske loptice, za koje se navodi da su služile kao municija za praćku. ${ }^{103}$
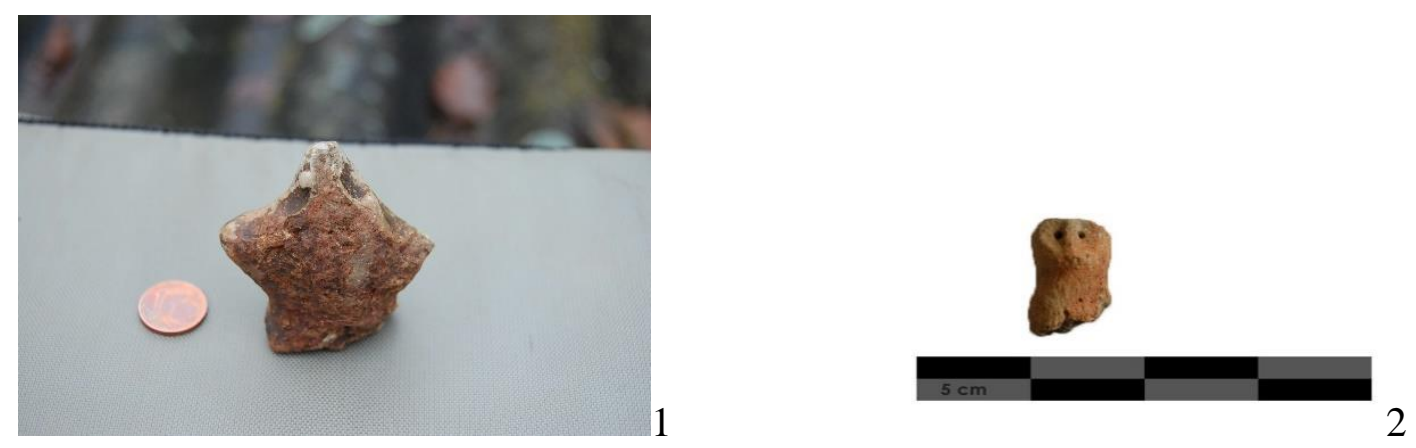

Slika 25. Figurine (snimili: sl. 1 - G. Tiefengraber; sl. 2 - Dž. Brigić)

Također, u izvještaju o nalazima stambenih objekata u vidu podnica u sondi I navodi se sloj prethistorijskog humusa između dva kulturna sloja (vinče i starčeva). Nažalost ne postoje nikakvi podaci na kojoj se dubini nalazi navedeni sloj koji bi odvajao Starčevo od Vinče, s ozbirom na to da Čović izrazito navodi kako ni u jednom momentu nije naišao na bilo kakav sterilni sloj (Čović 1960-

\footnotetext{
102 Lokacija figurine navodi se samo u nekoliko isječaka iz dnevnih novina, gdje se citira voditelj istraživanja, Zilka Kujundžić-Vejzagić, koja - prema novinama - kaže da je figurina pronađena u šutu.

${ }^{103}$ Izvještaj sa arheološkog iskopavanja na lokalitetu neolitskog naselja u Gornjoj Tuzli 2009. godine.
} 
61: 88). Dalje se navodi kako su se ispod podnice nalazili ostaci krupnijeg riječnog kamena, a između ova dva kulturna sloja, odnosno ostataka kuća, pronađeni su ostaci riječnog šljunka. Dakle, ne može se sa sigurnošću situirati spomenuti sloj prethistorijskog humusa koji odvaja Starčevo od Vinče, sa ostacima podnica između kojih se nalazi sloj riječnog šjunka. Jedino što se može uzeti kao baza za pokušaj determinisanja o kojoj dubini je riječ, jeste podatak u izvještaju kako su, u šestom otkopnom sloju, ispod ognjišta i podnice pronađeni ostaci ljudskih kostiju (Izvještaj 2009: 2). Ukoliko je riječ o ranije spomenutim podnicama, podatak da se nalaze u šestom otkopnom sloju omogućuje nešto lakše razumijevanje dubine na kojoj su pronađene. Naime, preko signatura deponovane keramike u Muzeju Istočne Bosne u Tuzli utvrđeno je kako se treći otkopni sloj zapravo nalazi na dubini od 0,50 m, dok je četvrti otkopni sloj sa dubine 0,60 m. Uzevši u obzir da su četiri otkopna sloja odvojena na dubini od svega 0,60 m, može se pretpostaviti kako šesti otkopni sloj ne bi trebao biti maksimalno ispod dubine od $1,0 \mathrm{~m}$ a minimalno $0,70 \mathrm{~m}$, čime se navedeni sloj može vertikalno okvirno smjestiti. Zahvaljujući tom podatku i narednoj rečenici u inače veoma šturoj dokumentaciji, u kojoj se navodi da su radi analize C14 prikupljeni ostaci gari i kostiju koji su poslati na analizu u Beč, dokument iz Vienna Environmental Research Accelerator, izdat 4. marta 2008. godine, pruža krucijalno važne rezultate datiranih nalaza, čime je Gornja Tuzla dobila nove datume. Ipak, trenutno ne postoji način da se utvrdi sa koje su tačno dubine uzeti nalazi za radiokarbonsku analizu, odnosno da li oni pripadaju šestom otkopnom sloju ili je riječ o nalazima uzetih sa neke druge dubine.

Istraživanje iz 2008. godine za cilj je imalo da utvrdi prostor pružanja naselja i lociranja terena za otvaranje novih sondi (Izvještaj 2008). Prema izvještaju, sonda II (4 x 4 m) otvorena je sjeverno od Društvenog doma, na udaljenosti od $40 \mathrm{~m}$, dok se prema Dnevniku sa arheološkog istraživanja na lokalitetu neolitskog naselja Gornja Tuzla ${ }^{104}$ navodi da je sonda II veličine 3 x 3 m i da se nalazi 20 m južnije od sonde I te 40 m istočnije od objekta Društvenog doma. Nameće se logično pitanje: gdje se tačno nalazi sonda II? Nisu navedene nikakve koordinate kao za sondu I, a u dva krucijalno bitna dokumenta pisana/predata u dva dana (22. i 23. jula 2008.) navode se različiti podaci o njenom geografskom smještaju. U novim iskopavanjima, vršenim u augustu 2018. godine u svrhu pisanja ovog rada, otvoreno je nekoliko sondi sa identičnim ciljem determinisanja granica naselja, konkretno južne granice. Dodatno, u jednom telefonskom razgovoru gospodino Bakalovićem je rekao kako su sonde II, III, i IV beskorisne, odnosno da tamo nisu ništa konkretno pronašli te da se sonda II nalazila također sjeverno preko ceste koja prolazi iznad škole. Zbunjujuće je što se u navedenim

\footnotetext{
104 Dnevnik sa arheološkog istraživanja na lokalitetu neolitskog naselja Gornja Tuzla 14.07-19.07.2008. godine (04157/08), 23. jula 2018. godine.
} 
izvještajima navodi kako su sonde III i IV otvorene 200 m sjevernije od Društvenog doma, dok se za sondu II navodi svega $40 \mathrm{~m}$. Trebalo bi ipak pretpostaviti da je podatak o otvaranju sonde II preko ceste vjerodostojniji, jer južnije od ceste poznat je bogat kulturni sloj, o čemu svjedoči Čovićevo iskopavanje, kao i sonda IV iz 2018. godine.

Prilikom otvaranja sonde II (prema izvještaju sa arheoloških iskopavanja 2018. godine) ${ }^{105}$ koja se nalazi na k.č. 618 svega nekoliko metara južnije od Društvenog doma, sudeći prema šturim nalazima i nailasku na moderni austrougarski/jugoslavenski bunar ili šaht (za koji, prema usmenim informacijama, ni mještani nisu znali da postoji), i uz prirodno- geografsku strukturu terena i lokaciju sonde na ravnom dijelu tela, zaključeno je kako ona ne ulazi u okvire neolitskog naselja u Gornjoj Tuzli. Vodeći se tom pretpostavkom, treba zaključiti kako je lokacija sonde II-2008 sjevernije od Doma, kako je to navedeno u izvještaju iz 2008. godine, ali trenutno ne postoji način da se sazna tačna veličina ove sonde i istražene površine. Nakon što se skinuo humus i sloj šuta iz sonde II, došlo se do kompaktnog kulturnog sloja, ali nažalost nigdje nije navedena konkretna dubina na kojoj se došlo do prvih nalaza. Jedini potencijalni način determinisanja dubine jeste komparacija, ako se uzme u obzir moguća lokacija sonde zahvaljujući istraživanjima iz 2018. godine kada je otvorena sonda (sonda IV-2018) sjevernije u odnosu na sondu I iz 2008, a južnije od sonde II-2008, gdje se kulturni sloj pojavio na dubini od oko $0,50 \mathrm{~m} \cdot{ }^{106}$ Otkopom trećeg sloja ušlo se u prahistorijski humus i pristupilo čišćenju i zaglađivanju dna sonde i fotografisanju horizontalnog $i$ vertikalnog profila, te je uzeta dubina ovog otkopnog sloja (Dnevnik 2008: 3). Međutim, nigdje u dokumentaciji se ne navodi tačna dubina niti su priložene fotografije. Prema Dnevniku, četvrti otkopni sloj definisan je zdravim odnosno neporemećenim kulturnim slojem u kojem pored mnoštva fragmenata neolitske keramike preovladava vinčanska gruba keramika, te nalazi gareži i lijepa. Izvještaj daje konkretnije podatke i navodi da su pored pokretnog arheološkog materijala nađeni i ostaci ognjišta te kućnog lijepa, jedna figurina sa ljudskim likom za koju je pretpostavljeno da je bila sastavni dio žrtvenika ili drške kultne ili slične posude, te dvije fragmentovane kamene sjekire (Izvještaj 2008: 1). Dalje se u izvještaju navodi da su na toj dubini radovi zaustavljeni, da je nivo konzerviran, a sonda zatrpana i mapirana za dalja istraživanja. Međutim, dnevnik navodi kako je taj isti dan (15. jula 2008.) skidanje petog otkopnog sloja prekinuto zbog kiše, da bi već narednog dana (16. jula 2008.) navedeno da je zemlja petog sloja rastresita uz nalaze fragmenata keramike, životinsjkih kostiju i kremenog sitnog oruđa. Dalje se navodi da je sve više ostataka gareži i lijepa, pa je iz toga pretpostavljeno kako će se u narednim slojevima naići na ostatke nastambe ili ognjišta. Također, navodi se kako je radi

\footnotetext{
105 Izvještaj o arheološkim iskopavanjima na prostoru Gornje Tuzle, 27.08.2018-31.08.2018.

106 Izvještaj o arheološkim iskopavanjima na prostoru Gornje Tuzle 2018. godine (Brigić 2018: 13).
} 
efikasnijeg rada sonda podijeljena na sjeverni i južni dio te da se kopalo sve do devetog otkopnog sloja gdje su pored keramike pronađeni ostaci gari, tj ognjišta $i$ ljepa, tj podnice. Sonda je fotografirana, ucrtan je horizontalni i vertikalni profili i uzeta dubina sonde, a zatim su obustavljena iskopavanja ulaskom u kompaktan kulturni sloj. Postavlja se logično pitanje da li se radi o istom kompaktnom sloju o kojem izvještaj govori, i ako je tako, koliko je debeo kulturni sloj, te da li su otkopni slojevi (od petog do devetog) unutar istog kulturnog sloja, ili je u pitanju više slojeva?

Sonda III otvorena je na veoma zanimljivom mjestu, tačnije na vrhu tela oko $200 \mathrm{~m}$ sjeverno od Društvenog doma i ulaza u školsko dvorište. U dokumentaciji se navodi kako je sonda otvorena iza kuće Osmana Kušljugića, uz zapadnu ogradu, ali se nigdje ne navodi koja je katastarska čestica niti koje su koordinate sonde. Zahvaljujući imenu vlasnika i geportalu katastarskih čestica Gornje Tuzle (https://www.katastar.ba/geoportal/preglednik/), pretpostavlja se da je sonda otvorena na k.č. 687/1 gdje se, pored Osmana Kušljugića, navodi još dvadesetak imena na pregledu posjednika. ${ }^{107}$ Otvaranjem sonde III dimenzija 4 x 4 m ustanovljeni su debeo humusni sloj i konstatna vlažnost sonde, a zatim riječni šljunak, kao i postojanje dva bunara u neposrednoj blizi sonde - pretpostavilo se da se u prošlosti tu nalazio potok. U prva četiri otkopna sloja pronađeno je fragmenata osmanske, srednjovjekovne i prahistorijske keramike. Od petog otkopnog sloja postepeno se povećavaju nalazi prahistorijske keramike i ostaci kostiju domaćih životinja, kao i riječni šljunak i veće kamenje. Otkopom šestog sloja i značajnijom pojavom podvodnih voda, uz siromaštvo kulturnog sloja, radovi na sondi III su obustavljeni i sonda je zatvorena (Dnevnik 2008b: 4). Prilikom rekognisciranja terena Gornje Tuzle u svrhu priprema za iskopavanje lokaliteta 2018. godine, odustalo se od ideje otvaranja sondi na ovom prostoru s obzirom na to da se radi o vrhu tela i da su se mogli očekivati deblji nanosi zemlje prije nego bi se došlo do neolitskog perioda. Vjerovatno sa ciljem da se utvrdi postoji li veći potencijal na navedenoj katastarskoj čestici, uz istočnu ogradu otvorena je sonda IV dimenzija 1,5 x 3 m. Iskopano je osam otkopnih slojeva u kojima su, kao i u sondi III, pronađeni ostaci osmanske, srednjovjekovne i prahistorijske keramike te životinjskih kostiju. Otkopom devetog sloja ustanovila se glinovita zemlja sa nalazima prahistorijske keramike bronzanog i neolitskog perioda (Dnevnik 2008: 5), nakon čega su radovi na sondi završeni i ona je zakopana. Zaključeno je kako bi navedeni prostor mogao predstavljati pojilo za stanovnike naselja u Gornjoj Tuzli i njihovu stoku (Izvještaj 2008: 2). S obzirom na činjenicu da ni sonda III ni sonda IV nisu otkopane do kraja, teško je donositi konkretne zaključke. Može se pretpostaviti da je, ako je situacija identična na zapadnom i istočnom dijelu parcele, i centralni dio imao identične nalaze, ali kako je navedeno ranije, s ozbirom na lokacije sondi treba očekivati daleko deblje nanose i potencijalni kulturni sloj u odnosu na južni dio

107 https://www.katastar.ba/pregled 
naselja. Podaci o otkopnim slojevima nažalost ne pružaju više pojedinosti o konkretnim dubinama do kojih su sonde otvorene, a ni nedostatak fotografija u dokumentaciji ne olakšava process razumijevanja istraženog prostora.

Istraživanje provedeno od 2007. do 2009. godine ima veoma bitnu ulogu u razumijevanju lokaliteta Gornja Tuzla u geografskom ali najviše u hronološkom smislu. Nažalost, bez kompletne dokumentacije teško je govoriti o konkretnijim analizama s obzirom na to da se podaci o dubinama otkopnih slojeva ne mogu nabaviti, a samim time se i pronađeni nalazi veoma teško mogu staviti u kontekst. Olakšavajuću okolnost pruža istraživanje provedeno 2018. godine čiji je cilj bio da se odredi južna granica lokaliteta i pokuša ustanoviti vertikalna stratigrafija na kraju tela. Tim povodom otvoreno je pet sondi od kojih je jedna iskopana do zdravice i služit će kao osnovna baza za komparaciju slojeva na ostalim sondama. Prije samog iskopavanja na lokalitetu Gornja Tuzla, postavljeno je 12 geodetskih tačaka:

- P1-316.13ํ bolcna čelična, k.č. 619

- P2-318.16º bolcna čelična, k.č. 980, zid terase Društvenog doma

- $\quad$ P3-317.11 ${ }^{\circ}$ rupa u betonu, k.č. $620 / 2$

- $\quad \mathrm{P} 4-319,53^{\circ}$ drveni kolac, k.č. 630/2

- $\quad$ P5-318,94 drveni kolac, k.č. 630/2

- $\quad \mathrm{P} 6-317,13^{\circ}$ bolcna čelična, k.č. $632 / 3$

- $\quad \mathrm{P} 7-316,17^{\circ}$ bolcna čelična, k.č. 984

- $\quad$ P8-319,33 drveni kolac, k.č. 611

- P9-320,90 ${ }^{\circ}$ drveni kolac, k.č. $620 / 1$

- P10-351,22 ${ }^{\circ}$ alem minaret, jugozapadni dio džamije, k.č. 579

- P11-322,55 ${ }^{\circ}$ sljeme žute kuće jugoistočno od lokaliteta, k.č. 982

- P12-327,66 ${ }^{\circ}$ vrh na zgradi Društvenog doma, k.č. 981/2 
Tabela 6. Izvještaj GPS mjerenja iz Gornje Tuzle (2018.)

\begin{tabular}{|c|c|c|c|c|c|c|c|c|c|c|c|c|c|c|c|c|c|c|}
\hline $\begin{array}{l}\text { ta } \\
\check{c} \\
\mathrm{k} \\
\mathrm{a}\end{array}$ & $Y$ & $X$ & $\mathrm{Z}$ & \begin{tabular}{|l} 
WG \\
S \\
latit \\
uda
\end{tabular} & \begin{tabular}{|l} 
WG \\
$\mathrm{S}$ \\
long \\
ituda
\end{tabular} & $\begin{array}{l}\text { W } \\
G \\
\text { S } \\
\text { vi } \\
\text { si } \\
\text { na }\end{array}$ & \begin{tabular}{|l}
$X$ \\
EC \\
EF
\end{tabular} & \begin{tabular}{|l}
$\mathrm{Y}$ \\
$\mathrm{EC}$ \\
$\mathrm{EF}$
\end{tabular} & \begin{tabular}{|l}
$\mathrm{Z}$ \\
$\mathrm{EC}$ \\
$\mathrm{EF}$
\end{tabular} & $\begin{array}{l}\mathrm{Da} \\
\text { tu } \\
\mathrm{m}\end{array}$ & $\begin{array}{l}\text { Po } \\
\text { c. } \\
\text { mj } \\
\text { ere } \\
\text { nja }\end{array}$ & $\begin{array}{l}\text { E } \\
\text { po } \\
\text { he }\end{array}$ & $\begin{array}{l}\mathrm{M} \\
\mathrm{ax} \\
\cdot \\
\mathrm{H} \\
\mathrm{D} \\
\mathrm{O} \\
\mathrm{P}\end{array}$ & $\begin{array}{l}\mathrm{M} \\
\mathrm{ax} \\
. \\
\mathrm{V} \\
\mathrm{D} \\
\mathrm{O} \\
\mathrm{P}\end{array}$ & $\begin{array}{l}\mathrm{M} \\
\mathrm{ax} \\
\cdot \\
\mathrm{P} \\
\mathrm{D} \\
\mathrm{O} \\
\mathrm{P}\end{array}$ & \begin{tabular}{|l|}
$\mathrm{Vi}$ \\
$\mathrm{si}$ \\
$\mathrm{na}$ \\
an \\
te \\
ne \\
(fa \\
$\mathrm{zn}$ \\
$\mathrm{i}$ \\
$\mathrm{ce}$ \\
$\mathrm{nt}$ \\
ar)
\end{tabular} & $\begin{array}{l}\mathrm{H} \\
\text { or } \\
. \\
\mathrm{pr} \\
\mathrm{e} \\
\mathrm{c} .\end{array}$ & \begin{tabular}{|l} 
V \\
er \\
t. \\
pr \\
e \\
c.
\end{tabular} \\
\hline
\end{tabular}

\begin{tabular}{|l|l|l|l|l|l|l|l|l|l|l|l|l|l|l|l|l|l|l|}
\hline & 6.560 & 4.934 & 31 & $44^{\circ} 33^{\prime}$ & $18^{\circ} 45^{\prime}$ & 36 & 4.310 & 1.464 & 4.452 & 16.0 & $10:$ & & & & & & 0. & 0. \\
P1 & $\begin{array}{l}841 . \\
4884\end{array}$ & 6.1 & 21.24 & 38.66 & 1.2 & .728. & .196. & .570. & 9.20 & $30:$ & 31 & 0.8 & 1.3 & 1.6 & 2.0 & 0. & 00 & 01 \\
& 455 & 33 & $607^{\prime \prime}$ & $937^{\prime \prime}$ & 73 & 686 & 542 & 203 & 17 & 13 & & & 81 & 37 & 65 & 9 \\
\hline
\end{tabular}

\begin{tabular}{|c|c|c|c|c|c|c|c|c|c|c|c|c|c|c|c|c|c|c|}
\hline $\mathrm{P} 2$ & $\begin{array}{l}6.560 \\
.840 \\
526\end{array}$ & $\begin{array}{l}4.934 \\
.898 \\
722\end{array}$ & $\begin{array}{l}31 \\
8.1 \\
63\end{array}$ & $\begin{array}{l}44^{\circ} 33^{\prime} \\
21.69 \\
417^{\prime \prime}\end{array}$ & $\begin{array}{l}18^{\circ} 45^{\prime} \\
38.63 \\
312^{\prime \prime}\end{array}$ & $\begin{array}{l}36 \\
3.3 \\
03\end{array}$ & $\begin{array}{l}4.310 \\
.721 \\
124\end{array}$ & $\begin{array}{l}1.464 \\
.193 . \\
129\end{array}$ & $\begin{array}{l}4.452 \\
.581 \\
484\end{array}$ & $\begin{array}{l}16.0 \\
9.20 \\
17\end{array}$ & $\begin{array}{l}\text { 10: } \\
32: \\
31\end{array}$ & 30 & $\begin{array}{l}0.9 \\
50\end{array}$ & $\begin{array}{l}1.6 \\
92\end{array}$ & $\begin{array}{l}1.9 \\
40\end{array}$ & $\begin{array}{l}2.0 \\
65\end{array}$ & $\begin{array}{l}0 . \\
01 \\
0\end{array}$ & $\begin{array}{l}0 . \\
01 \\
8\end{array}$ \\
\hline
\end{tabular}

\begin{tabular}{|l|l|l|l|l|l|l|l|l|l|l|l|l|l|l|l|l|l|l|}
\hline & 6.560 & 4.934 & 31 & $44^{\circ} 33^{\prime}$ & $18^{\circ} 45^{\prime}$ & 36 & 4.310 & 1.464 & 4.452 & 16.0 & $10:$ & & & & & & 0. & 0. \\
P3 & .847. & .916. & 7.1 & 22.27 & 38.96 & 2.2 & .706. & .195. & .593. & 9.20 & $33:$ & 0 & 1.6 & 2.6 & 3.0 & 2.0 & 0. & 0. \\
& 680 & 697 & 07 & $431^{\prime \prime}$ & $487^{\prime \prime}$ & 47 & 159 & 779 & 504 & 17 & 47 & & 09 & 13 & 68 & 65 & 5 & 2 \\
\hline
\end{tabular}

\begin{tabular}{|c|c|c|c|c|c|c|c|c|c|c|c|c|c|c|c|c|c|c|}
\hline P4 & $\begin{array}{l}6.560 \\
.844 \\
120\end{array}$ & $\begin{array}{l}4.934 \\
.926 . \\
587\end{array}$ & $\begin{array}{l}31 \\
9.5 \\
26\end{array}$ & $\begin{array}{l}44^{\circ} 33^{\prime} \\
22.59 \\
578^{\prime \prime}\end{array}$ & $\begin{array}{l}18^{\circ} 45^{\prime} \\
38.80 \\
773^{\prime \prime}\end{array}$ & $\begin{array}{l}36 \\
4.6 \\
66\end{array}$ & $\begin{array}{l}4.310 \\
.702 . \\
314\end{array}$ & $\begin{array}{l}1.464 \\
.190 \\
810\end{array}$ & $\begin{array}{l}4.452 \\
.602 . \\
273\end{array}$ & $\begin{array}{l}16.0 \\
9.20 \\
17\end{array}$ & $\begin{array}{l}\text { 10: } \\
39: \\
41\end{array}$ & 0 & $\begin{array}{l}0.9 \\
02\end{array}$ & $\begin{array}{l}1.3 \\
18\end{array}$ & $\begin{array}{l}1.5 \\
97\end{array}$ & $\begin{array}{l}2.0 \\
65\end{array}$ & $\begin{array}{l}0 . \\
02 \\
3\end{array}$ & $\begin{array}{l}0 . \\
03 \\
6\end{array}$ \\
\hline
\end{tabular}

\begin{tabular}{|l|l|l|l|l|l|l|l|l|l|l|l|l|l|l|l|l|l|l|}
\hline & 6.560 & 4.934 & 31 & $44^{\circ} 33^{\prime}$ & $18^{\circ} 45^{\prime}$ & 36 & 4.310 & 1.464 & 4.452 & 16.0 & $10:$ & & & & & & 0. & 0. \\
P5 & .808. & .921. & 8.9 & 22.44 & 37.20 & 4.0 & .716. & .158. & .598. & 9.20 & $43:$ & 31 & 0.6 & 1.1 & 1.3 & 2.0 & 0. & 0 \\
& 756 & 453 & 39 & $016^{\prime \prime}$ & $326^{\prime \prime}$ & 79 & 499 & 228 & 438 & 17 & 52 & & 37 & 78 & 40 & 65 & 0 & 0 \\
6
\end{tabular}




\begin{tabular}{|c|c|c|c|c|c|c|c|c|c|c|c|c|c|c|c|c|c|c|}
\hline P6 & $\begin{array}{l}6.560 \\
.789 . \\
511\end{array}$ & $\begin{array}{l}4.934 \\
.897 . \\
919\end{array}$ & \begin{tabular}{|l}
31 \\
7.1 \\
33
\end{tabular} & $\begin{array}{l}44^{\circ} 33^{\prime} \\
21.68 \\
355^{\prime \prime}\end{array}$ & $\begin{array}{l}18^{\circ} 45^{\prime} \\
36.32 \\
138^{\prime \prime}\end{array}$ & $\begin{array}{l}36 \\
2.2 \\
72\end{array}$ & $\begin{array}{l}4.310 \\
.737 . \\
056\end{array}$ & $\begin{array}{l}1.464 \\
.144 . \\
654\end{array}$ & $\begin{array}{l}4.452 \\
.580 . \\
528\end{array}$ & $\begin{array}{l}16.0 \\
9.20 \\
17\end{array}$ & $\begin{array}{l}\text { 10: } \\
46: \\
42\end{array}$ & 31 & $\begin{array}{l}0.7 \\
33\end{array}$ & $\begin{array}{l}1.3 \\
88\end{array}$ & $\begin{array}{l}1.5 \\
69\end{array}$ & $\begin{array}{l}2.0 \\
65\end{array}$ & \begin{tabular}{|l}
0. \\
00 \\
7
\end{tabular} & $\begin{array}{l}0 . \\
01 \\
4\end{array}$ \\
\hline
\end{tabular}

\begin{tabular}{|c|c|c|c|c|c|c|c|c|c|c|c|c|c|c|c|c|c|c|}
\hline P7 & $\begin{array}{l}6.560 \\
.814 \\
409\end{array}$ & $\begin{array}{l}4.934 \\
.878 \\
751\end{array}$ & $\begin{array}{l}31 \\
6.1 \\
66\end{array}$ & $\begin{array}{l}44^{\circ} 33^{\prime} \\
21.05 \\
509^{\prime \prime}\end{array}$ & $\begin{array}{l}18^{\circ} 45^{\prime} \\
37.44 \\
135^{\prime \prime}\end{array}$ & $\begin{array}{l}36 \\
1.3 \\
06\end{array}$ & $\begin{array}{l}4.310 \\
.741 \\
342\end{array}$ & $\begin{array}{l}1.464 \\
.172 . \\
216\end{array}$ & $\begin{array}{l}4.452 \\
.566 \\
025\end{array}$ & $\begin{array}{l}16.0 \\
9.20 \\
17\end{array}$ & $\begin{array}{l}\text { 10: } \\
49: \\
26\end{array}$ & 31 & $\begin{array}{l}0.6 \\
92\end{array}$ & $\begin{array}{l}1.2 \\
85\end{array}$ & $\begin{array}{l}1.4 \\
60\end{array}$ & $\begin{array}{l}2.0 \\
65\end{array}$ & $\begin{array}{l}0 . \\
00 \\
7\end{array}$ & $\begin{array}{l}0 . \\
01 \\
3\end{array}$ \\
\hline
\end{tabular}

\begin{tabular}{|c|c|c|c|c|c|c|c|c|c|c|c|c|c|c|c|c|c|c|}
\hline P8 & $\begin{array}{l}6.560 \\
.869 \\
504\end{array}$ & $\begin{array}{l}4.934 \\
.940 . \\
508\end{array}$ & $\begin{array}{l}31 \\
9.3 \\
27\end{array}$ & $\begin{array}{l}44^{\circ} 33^{\prime} \\
23.03 \\
910^{\prime \prime}\end{array}$ & $\begin{array}{l}18^{\circ} 45^{\prime} \\
39.96 \\
375^{\prime \prime}\end{array}$ & $\begin{array}{l}36 \\
4.4 \\
67\end{array}$ & $\begin{array}{l}4.310 \\
.684 . \\
883\end{array}$ & $\begin{array}{l}1.464 \\
.211 \\
836\end{array}$ & $\begin{array}{l}4.452 \\
.611 \\
885\end{array}$ & $\begin{array}{l}16.0 \\
9.20 \\
17\end{array}$ & $\begin{array}{l}\text { 10: } \\
56: \\
09\end{array}$ & 31 & $\begin{array}{l}0.7 \\
48\end{array}$ & $\begin{array}{l}1.3 \\
54\end{array}$ & $\begin{array}{l}1.5 \\
47\end{array}$ & $\begin{array}{l}2.0 \\
65\end{array}$ & $\begin{array}{l}0 . \\
00 \\
8\end{array}$ & $\begin{array}{l}0 . \\
01 \\
5\end{array}$ \\
\hline
\end{tabular}

\begin{tabular}{|c|c|c|c|c|c|c|c|c|c|c|c|c|c|c|c|c|c|c|}
\hline P9 & $\begin{array}{l}6.560 \\
.852 . \\
270\end{array}$ & $\begin{array}{l}4.934 \\
.952 . \\
944\end{array}$ & $\begin{array}{l}32 \\
0.9 \\
00\end{array}$ & $\begin{array}{l}44^{\circ} 33^{\prime} \\
23.44 \\
717^{\prime \prime}\end{array}$ & $\begin{array}{l}18^{\circ} 45^{\prime} \\
39.18 \\
815^{\prime \prime}\end{array}$ & $\begin{array}{l}36 \\
6.0 \\
40\end{array}$ & $\begin{array}{l}4.310 \\
.683 . \\
081\end{array}$ & $\begin{array}{l}1.464 \\
.193 . \\
145\end{array}$ & $\begin{array}{l}4.452 \\
.621 . \\
964\end{array}$ & \begin{tabular}{|l|}
16.0 \\
9.20 \\
17
\end{tabular} & $\begin{array}{l}\text { 10: } \\
59: \\
18\end{array}$ & 31 & $\begin{array}{l}0.6 \\
39\end{array}$ & $\begin{array}{l}1.1 \\
74\end{array}$ & $\begin{array}{l}1.3 \\
37\end{array}$ & $\begin{array}{l}2.0 \\
65\end{array}$ & $\begin{array}{l}0 . \\
00 \\
8\end{array}$ & $\begin{array}{l}0 . \\
01 \\
5\end{array}$ \\
\hline
\end{tabular}

\begin{tabular}{|c|c|c|c|c|c|c|c|c|c|c|c|c|c|c|c|c|c|c|}
\hline $\begin{array}{l}\text { P7 } \\
26 \\
-\end{array}$ & $\begin{array}{l}6.559 \\
.875 \\
564\end{array}$ & $\begin{array}{l}4.932 \\
.092 . \\
516\end{array}$ & $\begin{array}{l}27 \\
1.5 \\
48\end{array}$ & $\begin{array}{l}44^{\circ} 31^{\prime} \\
51.07 \\
404^{\prime \prime}\end{array}$ & $\begin{array}{l}18^{\circ} 44^{\prime} \\
53.74 \\
613^{\prime \prime}\end{array}$ & \begin{tabular}{|l}
31 \\
6.6 \\
50
\end{tabular} & $\begin{array}{l}4.312 \\
.866 \\
265\end{array}$ & $\begin{array}{l}1.463 \\
.874 \\
991\end{array}$ & $\begin{array}{l}4.450 \\
.555 \text {. } \\
027\end{array}$ & $\begin{array}{l}16.0 \\
9.20 \\
17\end{array}$ & $\begin{array}{l}\text { 12: } \\
45: \\
28\end{array}$ & 30 & $\begin{array}{l}0.9 \\
35\end{array}$ & $\begin{array}{l}1.5 \\
15\end{array}$ & $\begin{array}{l}1.7 \\
80\end{array}$ & $\begin{array}{l}2.0 \\
65\end{array}$ & $\begin{array}{l}0 . \\
00 \\
8\end{array}$ & $\begin{array}{l}0 . \\
01 \\
3\end{array}$ \\
\hline
\end{tabular}

Nakon toga, cjelokupno naselje Gornja Tuzla snimano je dronom DJI Phantom 3, te su uzeti fotografski, video, ortofoto i 3D snimci lokaliteta (T. 61-64). Tek tada je dogovoreno probno sondiranje koje je izvršeno 16. maja 2018. godine sa ciljem da se na k.č. 617, 618 i 619 ustanovi rasprostranjenost materijala. Otvoreno je 6 probnih sondi koje su kopane do prvih nalaza (T. 65). ${ }^{108}$ Neposredno prije samog kopanja postavljene su geofizičke mreže 20 x 10 m smjera sjeversjeverozapad i navedene katastarske čestice su snimljene. Unaprijed se znalo da su na određenim mjestima kopani kanali za sprovođenje struje i grijanja za osnovnu školu, pa su se prilikom kopanja ta mjesta zaobišla, a tačne lokacije su određene zahvaljujući rezultatima geofizike. Probna sonda I otvorena je sjevernije od geofizičke mreže budući da se taj dio zbog zaraslog terena nije mogao

\footnotetext{
${ }^{108}$ Za georeferenciranje sondi korišteni su rover, radar, resistivity (RM\&S) (Dnevnik 16.05.2018.).
} 
snimiti. Ona je ciljano otvorena s obzirom na to da se nalazi direktno ispod sonde I-2008 (Safetova bašča) a predstavljala je najbliže moguće mjesto zbog ograde koja dijeli parcelu 616 (Sonda 1-2008) sa snimanom parcelom 617. Probne sonde pokazale su identične rezultate na svim mjestima, pa se pretpostavilo kako se erozijom zemlje navuklo izmiješanih materijalnih nalaza. Zahvaljujući tome, kao i rezultatima geofizike, odlučeno je da se otvori po jedna sonda na sjevernom, tj. južnom dijelu parcela 617/618. Dubine nalaza i slojeva snimane su nivelirom - nula je iznosila 167 (na putu pored P1 na k.č. 619).

Na južnom dijelu parcele otvorena je sonda II dimenzija 3 × 3 m, da bi se ispostavilo kako sonda izlazi van okvira neolitskog lokaliteta. Budući da se na dubini od pola metra pojavila moderna austrougarska/jugoslavenska gradnja, pretpostavlja se da je riječ o bunaru ili šahtu (za koji mještani nisu znali da postoji) te je on ostavljen za buduća istraživanja (T. 66). Samim time, kao i prema prirodno-geografskom položaju na telu odnosno na dijelu tla koje je u potpunosti ravno, ustanovljeno je da neolitsko naselje tu završava. Taj podatak je veoma bitan s ozbirom na to da odražava širu sliku rasprostiranja naselja odnosno njegova južnog kraja. Na sjevernom dijelu, na k.č. 617, otvorena je prva sonda (sonda I-2018), svega desetak metara ispod sonde I iz 2008. godine; vlasnik parcele, razočaran iskopavanjima iz 2007./2009., nije želio ni da čuje o bilo kakvim arheološkim istraživanjima na njegovoj parceli koja prema svemu sudeći krije veoma bogate kulturne ostatke.

Sonda I je zamišljena da bude nešto većih dimenzija, ali zbog finansijskog i vremenskog ograničenja sužena je na dimenzije 1,8 x 1,5 m (T. 67). Prvi sloj je sačinjen od šute, izmiješanog materijala: cigla, pješčar, recentno staklo, drvo, kost, armatura, ekser itd. ${ }^{109}$ Idući sloj bio je smeđkaste boje i sa slabo zastupljenim materijalom; u njemu je pronađena plava kreda, vjerovatno iz okolne škole, što je pokazalo da je debljina recentnog sloja veća od očekivane. Na dubini od 0,70 m zemlja je imala narandžasto obojenje i sadržavala dosta fragmenata keramike s većom tendencijom pojavljivanja u sjevernom dijelu sonde, gdje se došlo do prvog kulturnog sloja koji su najviše karakterisale narandžasta boja sa dosta gareži debljine oko $0,30 \mathrm{~m}$, koje je najviše bilo u sjeveroistočnom dijelu sonde. Ovaj sloj ujedno predstavlja jedinu građevinsku fazu u sondi I, a najzanimljivija je činjenica da se identičan sloj sa gareži širi u jednakoj debljini na sve profile sonde, što znači da se ušlo u neki centralni dio građevine, posebno ako se uzme u obzir podatak da se jama ukopana u zdravicu nalazi direktno na sredini otvorene sonde (T. 68). Ispod sloja gareži ušlo se u dosta deblji kulturni sloj od 0,75 m, koji je u gornjem dijelu imao tamnosmeđkasto i crno obojenje, a u donjem dijelu sivkastotamno. Ovaj sloj bio je i posljednji sloj sonde I, nakon čega se na dubini od 1,70 m došlo do

\footnotetext{
${ }^{109}$ Pronađeni su ostaci glazirane keramike iz osmanskog perioda.
} 
zdravice. Zemlja je bila pjeskovita i mokra, a ilovača žućkasto-zelena. U zdravicu je ukopana jama uskog cilindričnog vrata dubine oko $0,20 \mathrm{~m}$, koji se pri većoj dubini loptasto širi. Jama je iskopana do dubine od 2,40 m, a sudeći prema nalazima trebalo bi je dodatno proširiti i vidjeti koliko još ide $u$ dubinu. Nažalost, zbog vremenskog ograničenja ti su radovi ostavljeni za naredni put, a dno sonde je pokriveno geotekstilom radi prezervacije nalaza. $U$ jami su pronađene loptaste manje posude okruglog dna, promjera oko $10 \mathrm{~cm}$, veoma grube fakture i bez ukrasa. U ovom sloju pronađeni su i fragmenti oboda sa bradavičastim ornamentima, kao i životinjske kosti. Na zidovima početka jame ustanovljena je nešto deblja širina izrazito žućkasto-zelenkaste ilovače koja se dalje od same jame pretvara u tamniju masniju zelenkastu boju, a u unutrašnjosti grla jame u profilu se primjećuju ostaci smeđkaste keramike, što bi značilo da je jama dosta veća od otkopanog (T. 69). Sudeći prema nalazima, to je vrlo vjerovatno bila jama za ostavu hrane, s obzirom na više manjih grubih posudica (u kojima se vjerovatno čuvala hrana) i životinjskih kostiju. No, postoji mogućnost da se zapravo ne radi o jami, nego o krušnoj peći, s obzirom na unutrašnji sastav zemlje, gareži i životinjskih kostiju, kao i zadebljanja na grlu otvora. Ipak, bez proširenja sonde i otvaranja cjelokupne dubine teško je doći do konkretnog zaključka.

Materijalni nalazi iz sonde I pružili su najbolje podatke o stratigrafiji Gornje Tuzle, ali s obzirom na veličinu i lokaciju sonde teško je za očekivati da se prate svi slojevi života ovog naselja. Ipak, u skladu sa onime što je pronađeno mogu se donijeti određeni zaključci. Najdublji slojevi u potpunosti pripadaju starčevačkoj kulturi bez ikakvih karekteristika vinčanskih elemenata, koji se pojavljuju tek u mlađim slojevima. Kada su u pitanju keramički nalazi iz sonde I, uključujući i recentne izmiješane slojeve, oni procentualno čine $70 \%$ od ukupnog iskopanog i signiranog keramičkog materijala. Svega $15 \%$ keramike iz sonde I pripada finoj, od koje je $40 \%$ sa određenim ukrasom. Prema tome, gruba keramika u potpunosti dominira kroz sve slojeve ove sonde. Od ukupne količine pokretnog materijala sonde I, 28\% otpada na recentne izmiješane slojeve. Keramika najdubljih starčevačkih slojeva, kojima pripadaju svi nalazi između 1,45 i 2,15 m, obuhvata 20\%, dok vinčanski slojevi, kojima pripadaju nalazi između 0,60 - 0,85 m, zauzimaju oko 9\% svih nalaza. Od životinjskih kostiju ukupno je pronađeno 145 koštanih ostataka, bilo da je riječ o većim ili manjim kostima, zubima, vilicama itd. U površinskom sloju zabilježena je svega jedna kost, dok najranijim starčevačkim slojevima pripada $17 \%$, a vinčanskim $64 \%$ nalaza. Velika većina kostiju pronađenih u vinčanskim slojevima pripada građevinskoj fazi, što bi imalo smisla s ozbirom na postojanje nekog objekta na ovoj dubini.

Najraniji nalazi sonde I potječu iz jame ukopane u zdravicu nekih 0,45 m koja pruža veoma korisne podatke o starčevačkoj keramici. U najdubljim razinama jame dominira gruba barbotin keramika sa 
dosta primjesa pljeve. Na dubini od 1,90 - 2,15 m pronađeno je nekoliko manjih posuda sa loptastim dnom, ${ }^{110}$ veoma grube fakture i sastava koja se mrvi i rasipa u rukama, ${ }^{111}$ zatim grubi fragmenti keramike među kojima dominira bradavičasta drška sa obodima ukrašenim utiskivanjem prstiju, dok su zidovi ovih posuda ukrašeni horizontalnim trakama nastalim povlačenjem prstiju na još uvijek vlažnoj površini posude (barbotin). Pronađeni su i fragmenti grube keramike sa plastičnim modeliranjem od kojih treba istaknuti jedan nešto veći komad sa polukružnom plastičnom trakom ukrašenom utiskivanjem prstiju (T. 70). Potrebno je izdvojiti i nekoliko fragmenata finije keramike iz ovih razina, tamno smeđe boje; jedan od tih fragmenata odnosi se na dio posude sa ravnim obodom, identične keramici kakvu je Čović pronašao na dubini od 5,45 m i koja je svrstana u grupu monohromne keramike, uglavnom ugasitosmeđeg tona, nekad bolje a nekad slabije glačane (T. 70). Drugi fragmenat pripada trbuhu te iste posude i na sebi ima urezane linije koje podsjećaju na neku vrstu crteža na kojem se relativno dobro mogu primijetiti oblik ljudskog tijela, glava, ruke i noge u raskoraku. Zanimljivo je da su oba fragmenta polirana sa vanjske i unutrašnje strane.

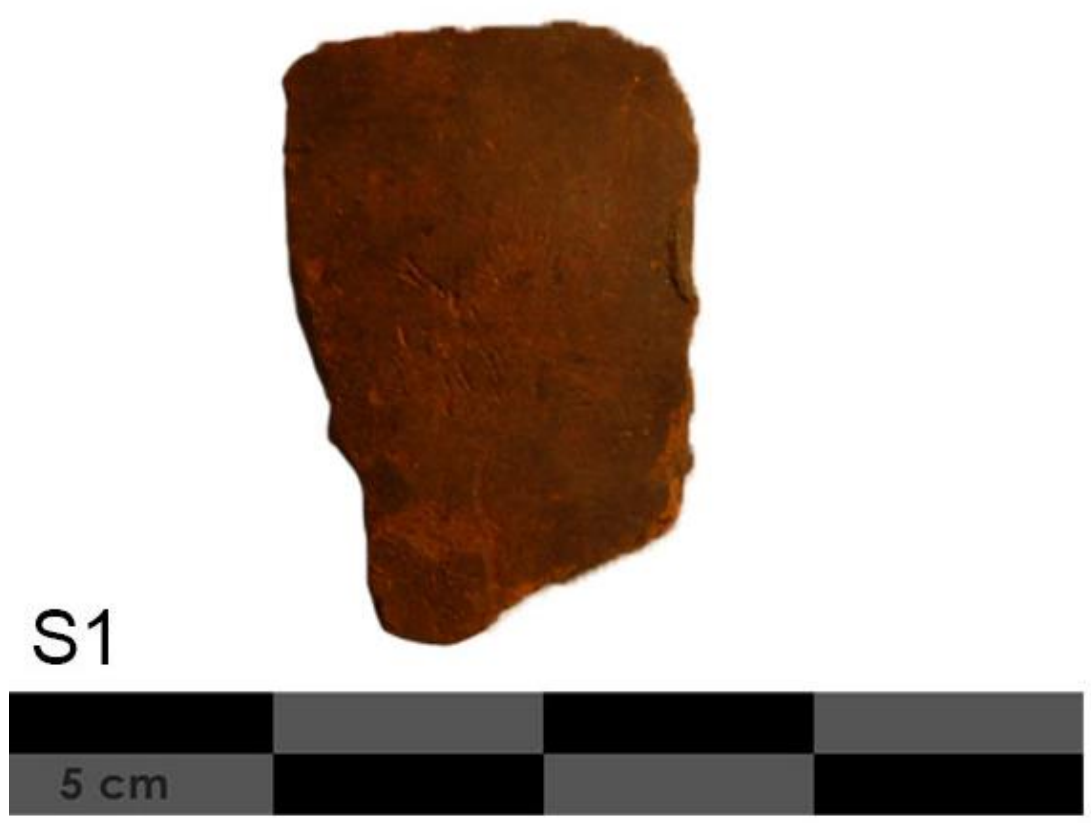

Slika 26. Fragmenat monohromne keramike sa crtežom? Fragmenat je uvećan radi bolje vidljivosti (snimio Dž. Brigić)

\footnotetext{
110 Čović je na osnovu fragmenata pretpostavio da najdubljem stratumu VIb pripadaju poluloptaste i loptaste monohromne posude sa ravnim dnom (Čović 1960/61: 84).

111 Čović je naveo kako se u najdubljim slojevima kod znatnog dijela posuda zidovi otiru pri dodiru (Čović 1960/61: 82).
} 
U gornjem dijelu jame zastupljeni su identični oblici manjih grubih loptastih posuda sa okruglim dnom, te zidova posuda ukrašenih povlačenjem prstiju što je površinu posude činilo nešto rebrastijom. Izuzetak čini nekoliko fragmenata slikane fine keramike ukrašene tamnijim premazom dobro prečišćene zemlje (Starčevo, spiraloid B) i jedan fragmenat ukrašen utiskivanjem noktiju na površinu posude - impresso (T. 70). Od izuzetnog su značaja dva fragmenta slikane keramike pronađena pri dubini od 1,90 $\mathrm{m}$ - na stijenkama keramike koja pokazuje boju primjećuje se "sendvič" presjek (središnji dio je crn, a iznad i ispod njega je crveni dio), što govori o načinu pečenja i veoma je indikativno za starčevačku kulturu. Pronađeno je i jedno dno posude sa zidom fine svjetlosmeđe boje, polirano sa vanjske i unutrašnje strane.

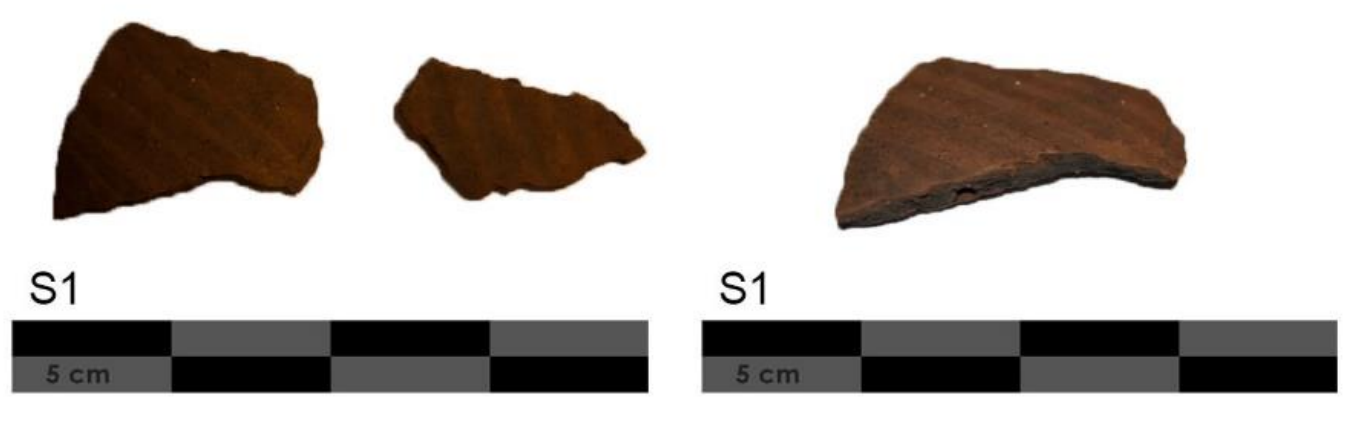

Slika 27. Slikana keramika sonde I-2018 (snimio Dž. Brigić)

Sve do zdravice odnosno do početka jame javlja se identičan materijal koji u potpunosti preovladava keramikom starčevačke kulture. Time je još jedanput utvrđeno da su najdublji slojevi Gornje Tuzle u potpunosti pripadali nosiocima starčevačke kulture koja je očito naselila veći prostor danas poznatog naselja. Sloj koji leži na zdravici, odnosno najstariji kulturni sloj sonde I, imao je sivkasto-tamno obojenje, a njegova debljina iznosi nekih $30 \mathrm{~cm}$ (sloj se proteže na dubini od 1,40 - 1,70 m). Keramika ovog sloja zadržava starčevačke karakteristike, što nije čudno s obzirom na to da je u pitanju najstariji sloj naselja, ali se primjećuje određen napredak u razvoju keramike. Nije pronađen nijedan fragment slikane keramike, što prema Čoviću čini jedan od glavnih faktora za razdvajanje VIb i VIa stratuma. Pronađen je svega jedan fragmenat urezane keramike smeđkasto-narandžaste boje, na kojem se primjećuje nedostatak pljeve u fakturi (T. 72, 3), što također predstavlja prelaz iz starijeg VIb u mlađi VIa stratum (Čović 1960-61: 88). Dominatna je gruba keramika barbotin tipa 
sa velikom primjesom pljeve, na kojoj se zadržavaju ravni obodi ukrašeni utiskivanjem prstiju smeđkasto-narandžaste boje i s bradavičastim plastičnim ispupčenjima odnosno drškama (T. 71). Novi oblik predstavlja jedan fragmenat sa trakastom drškom, tamnije smeđkaste boje, s primjesom koja se ne sastoji od pljeve već od krečnog pijeska (T. 72, 1). Detektovano je i nekoliko fragmenata na kojima se glina vezala sitnijim bjeličastim krečnim pijeskom (T. 72, 2), što u znatnoj mjeri karakteriše Čovićev VIa sloj. Keramika ovog sastava uglavnom je nešto bolje glačana, pa se primjećuje razlika u odnosu na stariju keramiku. Samim time Čovićeva podjela na stratume VIb i VIa bi imala smisla. Iako ne postoji nikakva vidljiva razlika u profilima sonde, odnosno njenom obojenju, očita je razlika u sastavu keramike i njenom pečenju. Pljeva je ostala u upotrebi do najmlađih perioda života u Gornjoj Tuzli, ali krečni pijesak se u sastavu keramike pojavio tek u mlađoj fazi Starčeva. U najmlađem dijelu ovog sloja, pri dubini od $1,30 \mathrm{~m}$, primjećuje se nešto značajnija upotreba sitnog krečnog pijeska u keramici, na kojoj i dalje dominira ravni obod ukrašen utiskivanjem prstiju. Pored toga, važno je spomenuti pojavu sivocrne grube keramike sa primjesom krečnog pijeska kakva u ranijim slojevima nije zapažena, kao i postepenu veoma blagu pojavu bikoniteta na posudama, ali to nije onaj klasični izraženi bikonitet vinčanske kulture. Važno je spomenti i jedan fragmenat sa urezanim motivima pronađen na ovoj dubini, koji u potpunosti odudara od ostalih. Naime, u pitanju je fragmenat sivkaste boje, sa veoma malim primjesama krečnog pijeska, na kojemu se primjećuju četiri paralelne urezane linije, prema svemu sudeći urezane nakon pečenja, od kojih se dvije spajaju i čine slovo V (T. 73, 1). Sličan urezani motiv na tamnijoj keramici već je ranije spomenut pri obradi keramike sa Čovićevog iskopavanja, čija je pripadnost determinirana u stratum III a pronađen je pri dubini od 3,05 m (T. 73, 2). Pri ovoj dubini pojavljuju se i prvi nalazi nogu žrtvenika od kojih se ističu dvije vrste: punjena noga sa nešto oštrijim dnom i punjena niža noga sa ravnim dnom. Sličan nalaz ustanovio je Čović pri vrhu svog stratuma V, koji predstavlja prelaznu fazu prema mlađim vinčanskim nalazima (T. 74). Čović navodi i jedan slučajan izolovan nalaz, posude sa čepastim nogama, ali takva je noga pronađena u sondi I pri dubini od 1,40 m. Ovaj nalaz, uz fragmenat urezane keramike i zajedno sa pojavom sivocrne grube keramike sa bikonitetom, ukazuje na pojavu nove populacije koja se naselila na prostoru Gornje Tuzle.

Naredni sloj, odnosno sloj na dubini između 0,85 i 1,25 m, sudeći prema sastavu i obojenju zemlje ne predstavlja sterilan sloj, ali u njemu nisu zabilježeni materijalni nalazi. U pitanju je sloj debljine $40 \mathrm{~cm}$ koji se ni po čemu, osim po nedostatku keramike, ne izdvaja od ostalih. U profilu sloja primjećuje se narandžasto obojenje, ali ono je vjerovatno nastalo od kućnog lijepa građevine koja je gorila iznad. Sa slojem gareži debljine oko $3 \mathrm{~cm}$ pri dubini od $0,70 \mathrm{~m}$, na koji se naslanja nešto deblji narandžasti sloj, nastaje novi život u sondi I. To je vrijeme nove kulture, jer se u sondi I-2018 može 
primijetiti, pri dubini od $0,85 \mathrm{~m}$ pa naviše, da se dešavaju određene promjene u materijalnim nalazima. Naime, keramika ovog sloja pokazuje nove elemente, odnosno elemente vinčanske kulture koja se razvila na jakoj osnovi starčevačke srednjeneolitske kulture. S1 Već u najdubljim dijelovima ovog sloja, na $0,85 \mathrm{~m}$, javljaju se bikonične forme crnoglačane keramike ukrašene kanelurama $(T$. 75, 76), što svakako predstavlja osnovnu karakteristiku vinčanske kulture.

Slika 28. Fragmenti sa impresso ukrasima (snimio Dž. Brigić)

Potrebno je još izdvojiti manje posude sa šupljim zdepastim nogama koje su pronađene u oba Čovićeva posve vinčanska stratuma, III i II (T. 77). Cjelokupan asortiman keramike pronađene u ovom sloju znatno je bolje pečen u odnosu na ranije, ali se i dalje zadržavaju pljeva i krečni pijesak kao glavni sastav zemlje (u znatno manjoj količini), ali to više nije ona gruba keramika koja se otire u ruci, nego je u pitanju poluglačana i glačana keramika kvalitetnijeg sastava, crvenkaste, sive i crne boje.

I dalje dominira crvenkastosmeđa keramika sa horizontalnim trakama izvedenima nekim vjerovatno drvenim predmetom, na kojoj se uglavnom ističu trakaste drške. Obodi su i dalje ravni i ukrašeni utiskivanjem prstiju, ali ima i primjeraka sa ravnim zadebljanim obodima (T. 78). Tradicija Starčeva pokazuje se i na jednom koničnom fragmentu ukrašenom gusto postavljenim udubljenjima izvedenima prstom. Da je ta tradicija izuzetno jaka pokazuje još nekoliko fragmenata crnosmeđe boje, na kojima se odmah ispod ravnog neukrašenog oboda nalaze urezani otisci nokta poredani horizontalno, što predstavlja tragove utjecaja impresso keramike iz ranijih slojeva.

U gornjim sedimentima ovog sloja, na dubini od $0,68-0,75 \mathrm{~m}$, primjećuje se učestalost vinčanske fine keramike. Dominiraju male bikonične zdjele koje su na trbuhu ukrašene uskim nježnim kanelurama. Uočeni su fragmenti sa dva (bradavičasta) ispupčenja na ramenu posudica čije se dvije drškice nalaze neposredno jedna pored druge, što u ranijim slojevima nije detektovano (T. 79, 80). $\mathrm{Na}$ jednom tamnom fragmentu bikonične poluglačane posude sa tragovima žućkaste pljeve i bijelog krečnog pijeska, uočavaju se impresso ukrasi otiscima prstiju ili nekog predmeta ispod oboda, što predstavlja prve ovakve ukrase na tamnijoj vinčanskoj keramici, a koji su ranije bili zastupljeni na starčevačkoj.

Pored klasične crnoglačane vinčanske keramike, i dalje se zadržava crvenkasto-narandžasta boja na uglavnom većim posudama, koje su vjerovatno služile za spremanje hrane i soli. Uglavnom su to 
barbotin posude iz najranijih slojeva sa obodom ukrašenim utiskivanjem prstiju i horizontalnim trakama na kojima još uvijek nema tragova bikoniteta (T. 81).

Jedan od glavnih oblika grubih posuda Čovićeva stratuma III jesu velike posude sa šiljatim dnom. To su u suštini konične posude koje završavaju na jednoj prema dole zaobljenoj nozi (rjeđe ravnoj), kakvih je u ovom sloju pronađeno više komada. Većina tih nogu se zapravo u nešto većoj mjeri naglo širi prema recipijentu čineći ga dovoljno širokim da podnese teret veće posude. Očito je da ove posude nisu mogle stajati na zemlji, nego su ih vjerovatno ubadali u zemlju i na taj način im osiguravali stabilnost. Noge su crvenkasto-smeđeg obojenja, grube ali sa relativno dobro glačanom unutrašnjom i vanjskom površinom. Posude ovog tipa, prema Čoviću, nisu imale nikakve drške, što se potvrđuje nalazima ovog sloja gdje su pronađeni veći fragmenti ravnih oboda bez drški bilo kakve vrste. U stratumu III Čović navodi jednu izuzetnu pojavu fragmenata suda sa kljunom za izlivanje ( $\mathrm{T}$. 77), kakav je pronađen i u sondi I-2018 pri dubini od $0,80 \mathrm{~m}$. U pitanju je tamnosmeđi fragmenat veoma grube konture ali sa ravnom poluglačanom površinom na kojoj se vidi dosta pljeve, a kljun za izlijevanje tečnosti se veoma jasno definira. On predstavlja jednu od osobina stratuma II prema Čoviću, ali su nažalost zbog nešto debljeg recentnog površinskog sloja gornji slojevi sonde u potpunosti uništeni i ne može se reći ništa konkretnije.

S obzirom na to da je sonda II zatvorena, bilo je odlučeno otvoriti treću sondu dvadesetak metara istočnije od prve, na istoj parceli. Ona je zamišljena kao probna sonda dimenzija 3 x 2 m, kako bi se ustanovilo da li se naselje širi dalje prema istoku. Taj dio morao se pokositi i trebalo je isrkrčiti divlje biljke koje su obrasle sjeveroistočni dio parcele. Prema rezultatima inicijalnih iskopina, ona nije bila oštećena ljudskom rukom u ranijim naseljavanjima, kopanjima, poljoprivrednim radovima, kopanjem bunara i sl., odnosno recenti sloj je dosta plići u odnosu na sondu I. Već na dubini od oko pola metra kroz cijelu se sondu počela pojavljivati crvenkasta keramika pomiješana sa kućnim lijepom, pa je sonda zatvorena i ostavljena za dalja istraživanja (T. 82). 
Tabela 7. Koordinate sonde III

\begin{tabular}{|l|l|l|l|l|l|}
\hline Grid & \multicolumn{2}{|l|}{ Lat/Lon hddd ${ }^{\circ}$ mm.mm' } & & \\
\hline Datum & WGS 84 & & & & \\
\hline & & & & & \\
\hline Header & Name & Description & Type & Position & Altitude \\
\hline & & & & & \\
\hline Waypoint & 53 & & User Waypoint & N44 33.367 E18 45.662 & $316 \mathrm{~m}$ \\
\hline Waypoint & 54 & & User Waypoint & N44 33.365 E18 45.663 & $316 \mathrm{~m}$ \\
\hline Waypoint & 55 & & User Waypoint & N44 33.365 E18 45.665 & $316 \mathrm{~m}$ \\
\hline Waypoint & 56 & & User Waypoint & N44 33.366 E18 45.664 & $316 \mathrm{~m}$ \\
\hline
\end{tabular}

Zapadnije od sonde I, na sjevernom dijelu parcele 619 nekoliko metara od Društvenog doma, otvorena je sonda nazvana Usjek I. Ona je otvorena radi poređenja nalaza sa sondom I, kao i jednostavnosti otvaranja "usjeka" s obzirom na to da se zemlja morala skinuti samo sa jedne strane jer su ukopani temelji zgrade. Samim time, očekivalo se da debljina recentnog sloja bude nešto veća, što se i pokazalo. Kao najviša tačka uzeta je sjeveroistočna strana sonde te se skinulo oko $80 \mathrm{~cm}$ zemlje kako bi se tlo poravnalo sa zapadnim ravnim dijelom pored zgrade (T. 83). Pri dubini od $1 \mathrm{~m}$ javlja se narandžasti sloj sa gareži, koji se širi dalje u profil prema sjeveru i istoku i predstavlja prvi građevinski sloj. Sloj od 1,20 - 1,40 m dubine (u dokumentaciji vođen kao šesti sloj) predstavlja drugi kulturni sloj ove sonde, tamnosive boje, sa fragmentima naradžaste keramike u profilu koja mu daje malo svjetliju boju, odnosno sloj nivelacije (međusloj). On se direktno naslanja na još jedan sloj gareži i keramike pri dubini od 1,60 m, koji se u ovom slučaju širi na zapadni profil sonde i predstavlja još jedan građevinski sloj koji se jednim dijelom miješa sa narednim četvrtim slojem najvjerovatnije slojem nivelacije. Pri dubini od 1,87 m, odnosno na prelazu iz trećeg građevinskog sloja u četvrti, pronađena su dva fragmenta slikane glačane fine keramike, tamnije narandžaste boje sa crnim premazom. Kroz sloj nivelacije prema zapadnom profilu proteže se jedan sivi sloj debljine 10-ak $\mathrm{cm}$ - to je najvjerovatnije sloj pepela ispod kojeg se nadovezuje naredni, šesti sloj odnosno sloj identičan četvrtom. Kao što je rečeno, sloj 4 je vjerovatno zapravo sloj nivelacije, nastao prije 
gradnje u sloju 3. S obzirom na nalaze u profilu sonde, kao i na sitne fragmente keramike u posljednjem sloju nivelacije, ovaj sloj ne predstavlja zdravicu ali je zbog nedostatka vremena sonda morala da se zaustavi na ovom mjestu, iako se njen kraj očekivao veoma brzo, za svega nekih 15-20 $\mathrm{cm}$.

U poređenju sa materijalom iz sonde I, keramika iz Usjeka daleko je malobrojnija. Gruba keramika čini $15 \%$ od ukupnog iskopanog materijala, dok svega $9 \%$ cjelokupne grube keramike iz Usjeka ima neke ukrase. Fina keramika također čini $15 \%$ od ukupnog materijala iz svih sondi, a ukrasi se nalaze na svega 36\% keramičkih ostataka. ${ }^{12}$ Samim time, veoma je teško ustanoviti statigrafiju, posebno ako se uzme u obzir da zaključno sa dubinom na kojoj se nalazi ranije navedeni sloj "pepela" $(1,87$ m) prestaju keramički nalazi, izuzev sitnijih fragmenata koji se ne mogu podvrgnuti detaljnijoj analizi. ${ }^{113}$ Ono što ipak predstavlja izuzetno vrijedne nalaze jesu dva fina fragmenta slikane keramike tamnosmeđe boje (T. 85). Ta je keramika rađena bez primjesa pljeve i sa veoma malo krečnog pijeska, a oslikana je tamnom bojom po svjetlijoj površini. Motivi na tim fragmentima su pravolinijski, ali se primjećuje da je tamna ukrasna boja spojena kružno preko krajeva fragmenata, što bi moglo predstavljati neki drugačiji geometrijski oblik. Zanimljivo je što se na jednom fragmentu boja gotovo isprala, iako Čović napominje kako se boja ne skida pri dodiru niti pod uticajem vode. U ovom slučaju to nije tako, jer se prilikom nešto jačeg pritiska spužvicom na podlogu moglo primijetiti da se ukras ispira. Ostali keramički nalazi iz ovog sloja pokazuju karakteristike mlađe faze starčevačke kulture, tamne monohromne i barbotin keramike pri čijem se pečenju kao primjesa uglavnom koristi krečni pijesak, dok su grubi fragmenti sa dosta žućkaste pljeve zapravo nešto ravniji i ne rasipaju se pri dodiru. Detektovano je svega nekoliko takvih fragmenata, a na jednom od njih primjećuju se horzontalne trake ispod oboda koji nije ukrašen utiskivanjem prstiju. Keramika iz ovog sloja ne pruža neke konkretne podatke, ali s obzirom na fragmente slikane keramike, za koju Čović kaže da se ne pojavljuje ni u jednom drugom stratumu osim u stratumu VI, pretpostavlja se da je u pitanju finalna faza starčevačke kulture. U prilog tome govori i pojava prve fine crvenkaste i crne bikonične posudice zajedno sa monohromnom keramikom ukrašenom utiskivanjem prstiju ispod oboda, što pokazuje miješanje dvije kulture uočljivo u prelaznom stratumu V sonde I-1958 (T. 87). pro

Prilikom traženja dozvole za iskopavanje, kao i zbog želje da se iskopa jedna sonda na sredini tela, navedena je i parcela u privatnom vlasništvu, k.č. 615 (T. 88). No, zbog kompleksnosti problema

\footnotetext{
112 Nalazi kostiju iz Usjeka veoma su malobrojni, čine svega 2,5\% od cjelokupnih nalaza.

${ }^{113}$ U šutu zemlje izbačene iz ovih dubina pronađena je jedna glačana kamena sjekira. Ona se ipak ne može staviti u kontekst s obzirom na manjak pažnje prilikom izbacivanja zemlje iz sonde.
} 
porodične razjedinjenosti vlasnika parcele, nije vjerovatno da će se dobiti saglasnost, a samim time nije ni planiran iskop na ovom dijelu terena. Ipak, jedna od vlasnica ove parcele dozvolila je da se otvori manja sonda dimenzija 1,55 x 1,80 m. Nazvana je sondom 4, s visinom vrha sonde 322 a dna $320 \mathrm{~m}$ u odnosu na nulu. Imajući u vidu da se ova parcela nalazi na sredini tela, s pravom je bilo za očekivati dublji kulturni sloj. ${ }^{114}$ Ipak, otvaranje ove sonde mnogo je doprinijelo budućim istraživanjima, jer već na oko pola metra dubine ušlo se u kulturni sloj koji je pokazao bogatstvo pokretnih nalaza i kvalitetnije mlađe keramike boljeg sastava i ljepših ukrasa. Naredni sloj, ispod humusa, imao je smeđkasto tamno obojenje zemlje sa većom količinom lijepa. Treći sloj je također imao smeđe obojenje ali sa manjom količinom primjesa lijepa, a četvrti je bio sličan sloj sa većom količinom usitnjenog lijepa. Slojevi 2, 3 i 4 mogu se posmatrati kao jedna cjelina sa različitim koncetracijama lijepa, što im daje drugačije konotacije. Na to se nastavlja nabijeni žućkasto-smeđi sloj, dok je naredni šesti sloj ujedno prvi građevinski sloj ove sonde. Sloj ispod građevinskog je nabijeni zelenkasto-sivi i predstavlja nekakav sloj nivelacije ili prirodnog zatrpavanja te miješanja sa obradom zemlje, dok su posljednji slojevi 8, 8a, 9 i 10 zapravo dijelovi iste, tj. naredne građevinske faze (T. 89, 90). Ova sloj je ujedno pružio najviše nalaza - pronađeni su tragovi gorenja ispod kojeg je bio deblji crvenkasti sloj pomiješan sa rastresitim kućnim lijepom i keramikom. Pri dnu ovog sloja naišlo se i na kućni lijep ispod kojeg se javila plavakasto obojana kraterisana zemlja od koje je uzet uzorak radi daljih ispitivanja. Na prvu je djelovalo kao da je u pitanju troska, ali sa dosta rezerve $s$ obzirom na dubinu na kojoj je pronađena, što se kasnije i pokazalo ispravnim. U pitanju je sintetirani lijep: silikati u glini izloženi temperaturi između 900 i 1200 stepeni rastvaraju se i počinju prelaziti u staklasti oblik koji podsjeća na trosku. Direktno ispod sloja kućnog lijepa, u zapadnom dijelu sonde na dubini od $1,70 \mathrm{~m}$, došlo se do naslaganih kamenica čiji je izgled podsjećao na podnice polukružnog tipa. Neposredno pored (istočni dio) "podnica" ležala je konična posuda sa šiljatim dnom (promjera oko $50 \mathrm{~cm}$ ) većih dimenzija, koja se pokušala izvaditi in situ, ali se zbog rastresitosti zemlje raspala, prilikom čega je dokumentovana, fotografski zabilježena, signirana i izdvojena (T. 91). Kako je došlo vrijeme da se radovi privedu kraju, sonda je zatvorena pri dubini od $1,90 \mathrm{~m}$ i ostavljena za buduća istraživanja koja će zahtijevati veća finansijska sredstva zbog kompleksnosti sonde i očekivanih većih rezultata, s obzirom na to da podnice ulaze u sjeverni i zapadni profil sonde te da se rastresita zemlja širi na jugozapadni dio sonde.

Keramika iz sonde 4, odnosno njenih najdubljih slojeva, sačuvala se u jako velikim fragmentima u odnosu na ostale nalaze, na osnovu čega se može pretpostaviti da su se na ovom mjestu proizvodile

\footnotetext{
114 Nedaleko od ove sonde IV, u pravcu sjeveroistoka Čović je 1960tih otvorio svoju sondu gdje je kopao do 5,5m u dubini pa se znalo da je bilo nemoguće očekivati neke značajnije rezultate u preostalom vremenu.
} 
velike posude, najvjerovatnije za čuvanje soli. Gruba keramika iz sonde IV obuhvata 8,50\% od ukupnih nalaza, od čega 30\% ima neke ukrase. Fina keramika čini oko $8 \%$ u odnosu na cjelokupne nalaze, od čega čak 70\% ima ukrase među kojima dominiraju kanelure odnosno horizontalne trake. S obzirom na to da sonda IV nije iskopana do kraja, potrebno je pokušati razjasniti do kojeg se sloja uopšte došlo. Naime, glavni oblik grube crvenkaste keramike stratuma III predstavlja posuda sa šiljatim dnom, koja je ona ležala na dubini od 1,90 m (T. 92, 93). Imajući u vidu dubinu na kojoj je pronađena, podatak da je sonda IV locirana nešto južnije od sonde II-1958, kao i zašiljenost noge, pretpostavlja se da se pri ovoj dubini nalazi granica između Čovićevih stratuma III i II, odnosno rani početak stratuma II. ${ }^{115} \mathrm{U}$ prilog tome govori još jedna posuda sa šiljatim dnom pronađena pri dubini od 1,70 m, ali njena šiljata noga već prelazi u zdepastu varijantu koja s druge strane predstavlja promjenu koja se desila u stratumu II (T. 94). Zanimljiv je podatak da se tradicija Starčeva provlači do najmlađih vinčanskih slojeva Gornje Tuzle. Naime, obje posude su rađene sa primjesom sitnog krečnog pijeska i imaju identične ukrase: horizontalne trake koje se provlače prstima ili nekim drvenim predmetom direktno ispod oboda i imaju tendenciju opadanja prema dnu, što je novina $u$ odnosu na ranije načine ukrašavanja. Ta dijagonalna tendencija vjerovatno je odraz vinčanskog načina ukrašavanja ovog posuđa koja, s druge strane, vuče tradicije iz najstarijih vremena, što je čini specifičnom za prostor Gornje Tuzle. Obodi posuda su i dalje ukrašeni utiskivanjem prstiju, ali uglavnom su postavljeni ukoso (dijagonalno) a ne ravno kao ranije. Na ovim posudama nisu detektovane drške, što nije ni čudno s obzirom na njihovo pretpostavljeno zakopavanje u zemlju. Ipak, s vanjske strane zida posude uočena su plastična ispupčenja koja su se vjerovatno nalazila na sve četiri strane posude i služila da se posuda ispod njih poveže nekom vrstom uzice kako bi se mogla prenositi (T. 95, 96, 97, 98). Sloj iznad ovih posuda sloj je kućnog lijepa koji je gorio na veoma visokoj temepraturi, pa je postao rastresit do te mjere da se lopatama morao izbacivati iz sonde. Iznad njega, na dubini od 1,63 m pronađen je fragmenat trbušaste posude sa izvraćenim obodom, kakva se pronalazi u stratumima III i II i potvrđuje svoju upotrebu u ovom periodu (T. 99). Prema Čoviću, te su posude obično bile bez ikakvih ukrasa, dok je fragmenat pronađen u ovoj sondi imao nizove udubljenja prstom ispod oboda, što i Čović navodi kao uobičajeni ornament za grubu keramiku. Ostala keramika ovog sloja u potpunosti odgovara onoj iz dubljih slojeva - zadržavaju se horizontalne (dijagonalne) trake po zidovima posuda i kosa udubljenja prstiju po obodu. Ovaj sloj od prethodnog petog sloja odvaja jedna građevinska faza iznad koje već ima prvih nalaza klasične vinčanske crnoglačane keramike. U sloju 5 pri dubini od oko jednog metra javljaju se bikonični oblici manjih crnosmeđih posudica, zajedno sa klasičnom grubom crvenkastom keramikom (T. 100).

\footnotetext{
${ }^{115}$ Prema stratigrafiji sonde II-1958, stratumi III i II počinju od dubine 3,75m i traju do 0,90 m, gdje stratumu III pripada svega $0,85 \mathrm{~cm}(3,75-2,90 \mathrm{~m})$, a stratumu II debeli sloj od 2 metra.
} 
Važno je istaći još nekoliko zanimljivih nalaza na ovoj dubini. Jedan od njih je fragmenat trbušaste posudice sa izvraćenim obodom ispod kojeg su vidljivi otisci prstiju kakvi su detektovani u dubljim slojevima, te zatim dva manja dna posudica grube sivorcrne keramike koji sa donje strane imaju otiske asure, što je prema Čoviću bitna karakteristika stratuma III i II (T. 101, 1-3). Pronađen je i jedan manji fragmenat grube sivocrne keramike koji na sebi ima ucrtan veoma zanimljiv znak: povučena je vertikalna linija koja se pri vrhu račva u četiri različita smjera. Sličnih nalaza ima i u sondama II-1958 i I-2018., pa se može reći da ovi ucrtani "simboli" predstavljaju karakteristiku crne keramike iz vinčanskih slojeva Gornje Tuzle (T. 102, 1-3). Imajući u vidu da se veoma slični nalazi sonde IV provlače kroz sve iskopane slojeve, njihova se pripadnost može sa velikom vjerovatnoćom smjestiti u Čovićev stratum II. Pronađeni su i elementi starijeg stratuma III, što nije čudno s obzirom na to da i sam Čović navodi kako je u pitanju dugi kontinuirani razvoj sa veoma postepenim zamjenjivanjem oblika, što se može konstatovati i na osnovu sonde IV-2018.

Istraživanje sondi 2018. godine pokazalo je južnu granicu naselja u Gornjoj Tuzli i još jednom potvrdilo postojanje starčevačkih slojeva zajedno sa karakterističnom slikanom keramikom i ostalim specifičnostima koje ova kultura nosi sa sobom. Vinčanski period života Gornje Tuzle rezultirao je bogatim nalazima i debelim kulturnim slojevima sa velikim brojem raznovrsnim oblika i karakteristika. Na osnovu uvida u cjelokupan materijal Gornje Tuzle sa posljednjeg iskopavanja, može se ustanoviti da se starčevačka tradicija zadržala veoma dugo kroz vinčanski period, te da je igrala značajnu ulogu u keramografiji stanovnika ovog naselja. Čović je na osnovu nalaza također utvrdio specifičnost Gornje Tuzle, pokušavajući da izdvoji specifičnosti kultura ovog naselja kakve nisu primjećivane na drugim lokalitetima, posebno kada je u pitanju vinčanska kultura. I tokom istraživanja provedenog 2007.-2009. godine primjećuje se tendencija izdvajanja prostora sjeveroistočne Bosne i Gornje Tuzle, kao najznačajnijeg lokaliteta, u istočnobosansku varijantu vinčanske kulture. Ovakva teza je potkrijepljena specifičnostima u razvoju vinčanske kulture na ovom prostoru, odnosno u Gornjoj Tuzli. Dakle, materijal Gornje Tuzle pokazuje dugu tradiciju od najranijih vremena, pri čemu se na osnovu keramografije može relativno dobro pratiti razvoj naselja, ali i činjenica da su zadržane ranije ideje kreiranja posuđa za svakodnevnu upotrebu. Takve su bile posude za čuvanje soli, kakve su prvi puta izrađivali nosioci starčevačke kulture: velike grube barbotin posud koje su uglavnom ukrašavane utiskivanjem prsta po obodu i povlačenjem horizontalnih traka po zidovima posude. Istina, tokom dugogodišnjeg razvoja života u Gornjoj Tuzli primjećuje se i napredak u proizvodnji tih posuda, koje su zatim rađene od dosta prečišćenije zemlje i imaju ljepše ukrase, ali se zadržava osnovna ideja ornamentisanja. Time se najbolje primjećuje snažan uticaj ranijih vremena, što s druge strane može značiti da je Gornja Tuzla živjela mirnim 
industrijskim životom sa ciljem eksploatacije soli kao glavne ekonomije, pored stočarstva i poljoprivrede. Gornja Tuzla je sol koristila u svakodnevne svrhe i navjerovatnije je prodavala okolnim naseljima, osiguravajući tako sebi život - koji traje i danas. 


\section{4d Pitanje apsolutne hronologije}

Tokom istraživanja koja je 1950-ih godina predvodio Borivoj Čović još uvijek nije bila razvijena konkretnija hronologija neolitskih kultura, posebno starčevačke i vinčanske. Iz tog je razloga Čović svjesno odlučio da se suzdrži od detaljnije analize i hronološke determinacije stratuma Gornje Tuzle. On kaže kako je apsolutna hronologija ovog naselja i pojedinih perioda života u njemu potpuno zavisna od fiksiranja apsolutne hronologije onih kultura ili grupa za koje se veže, pa stoga ne postoji potreba da se o tome ovdje detaljnije raspravlja (Čović 1960-61: 129). Nažalost, ni danas nije u potpunosti riješen problem hronologije starčevačke kulture s obzirom na to da ne postoji ujednačen hronološki sistem. Glavni razlog tome je prije svega nedovoljna istraženost lokalitetā starčevačke kulture (posebno u Bosni i Hercegovini), ali i ogroman prostor naseljavanja ove kulture na Balkanu. Uglavnom su posmatrane lokalne varijante na osnovu kojih je determinirana neka stratigrafija, uglavnom na osnovu ukrašene i slikane keramike. Tokom druge polovine 20. stoljeća ustanovljeno je nekoliko periodizacija starčevačke kulture, ${ }^{116}$ koje se uglavnom i danas sve koriste, iako se najčešće uzima relevantnom treća periodizacija koju je Stojan Dimitrijević predložio 1969. i dopunio 1974. godine. Prema Dimitrijeviću, najstariji stepen je monohromni; slijede linearni koji se dijeli na Linear A i Linear B, spiraloidni koji se također dijeli na Spiraloid A i Spiraloid B, te kao završni stepen tip Ždralovi odnosno razdoblje degeneracije (Dimitrijević 1974: 69). ${ }^{117}$

Kada je u pitanju Gornja Tuzla, ustanovljeni su elementi starčevačke kulture u najdubljim slojevima koji se naslanjaju direktno na zdravicu. Debljina starčevačkih slojeva je, prema Čoviću, iznosila 60 cm na središnjem dijelu tela, dok je na južnom perifernom iznosila $40 \mathrm{~cm}$ (što je ustanovljeno i sondom I-2018), što je sasvim razumljivo s obzirom na to da je riječ o tel naselju. Čović je pretpostavio da se najstariji dijelovi lokaliteta šire dalje na istok prema riječici Jali, a da se u kasnijim periodima naselje širilo prema zapadu. Na osnovu raspoloživih informacija, sakupljenih usmenim putem, nalazi iz željeznog doba utvrđeni su prilikom izgradnje džamije koja se nalazi istočnije između osnovne škole i Jale, dok to nije bio slučaj zapadnije od škole. Prema tome, moguće je pretpostaviti da se naselje širilo prema istoku, odnosno prema rijeci Jali, ali na tom prostoru dosada još uvijek nisu vršena istraživanja, pa se ne može ništa konkretnije reći. U prilog tome govori

\footnotetext{
${ }^{116}$ Prvu periodizaciju starčevačke kulture napravio je Vladimir Milojčić 1949. godine podjelom na četiri stepena. Drugu periodizaciju napravila je Draga Garašanin 1954. godine, također na četiri stepena. Treći periodizacijski sistem starčevačke kulture napravio je 1969. godine Stojan Dimitrijević, podjelom na pet stepeni. Milutin Garašanin 1971. godine dijeli starčevačku kulturu na četiri stepena. Dragoslav Srejović podijelio je starčevačku kulturu na pet stepeni. Prema Nikoli Tasiću, koji je dao najnoviju periodizaciju, starčevačka kultura se dijeli na pet stepeni (Klindžić, Hršak 2014: 16-19).

${ }^{117}$ Istraživanja Kornelije Minichreiter potvrđuju Dimitrijevićevu hronologiju (Minichreiter 2007a: 18-20).
} 
i Čovićeva dokumentacija u kojoj se spominje blagi nagib slojeva od istoka prema zapadu. Na osnovu raspoloživih rezultata provedenih istraživanja zna se da su nosioci starčevačke kulture naselili prostor Tuzle u relativno kasnijem periodu, što najbolje oslikavaju materijalni nalazi. Naime, gruba i fina slikana keramika prema fakturi, oblicima i načinu ornamentisanja u potpunosti odgovara starčevačkim nalazima sa ostalih lokaliteta. Imajući u vidu te identičnosti, kao i suzdržanost u hronologiji, Čović je odlučio da pažnju posveti razlikama koje je primijetio u odnosu na tadašnje poznate specifičnosti Starčeva. Istakao je jednu veoma bitnu razliku - nepostojanje bijele slikane keramike, što govori da na prostoru Gornje Tuzle nije zabilježena (barem ne zasada) starija faza starčevačke kulture, Linear A. Istraživanja na lokalitetu Galovo kod Slavonskog Broda, kojom su prilikom u zemunicama 205 i 207, datiranima $\mathrm{C}^{14}$ metodom, pronađeni fragmenti posuda sa bijelim slikanjem, pokazalo je rezultate od 6100-5700 godina pr. n. e. (Minichreiter 2007b: 23; Minichreiter 2006: 5). ${ }^{118}$ Rezultati ugljena sa istraživanja u Zadubravlju pokazali su postojanje ove faze između 6600 i 5300 godina pr. n. e., dok analize uzoraka ugljena iz Donjih Branjevina daju rezultate u vremenskom rasponu od 6100-5700 godina pr. n. e. (Karmanski 2000: 186). Sa druge strane, $C^{14}$ analize na lokalitetima u Srbiji, u Banatu i Bačkoj, pokazale su rezultate ove faze u periodu od oko 6000 godina pr. n. e. (Whittle, Bartosiewicz, Borić, Pettitt, Richards 2002: 93). Kasnijim fazama starčevačke kulture pripadaju lokaliteti Virovitica-Brekinja koji je apsolutno datiran u vremenski raspon od 5520 do 5080 godina pr. n. e., te Đakovački Selci-Kaznica-Rutak čiji su kasniji starčevački sediment datirani između 5305 i 5200 (Klindžić, Hršak 2014: 28).

Na osnovu svojevremeno poznatih periodizacija starčevačke kulture, Čović je dobro zaključio da slikanje bijelom bojom pripada starijem periodu, dok je slikanje tamnom bojom pripisao mlađem periodu, koji je Draga Garašanin tada determinisala nazivom Starčevo IIb, a koji je on izjednačio sa stratumom VIb. Mlađi stratum VIa najbolje karakteriše naglo opadanje slikane keramike, na osnovu čega je Čović zaključio da ovaj stratum izlazi iz stratigrafije starijih sedimenata Starčeva (Čović 1960-61: 109). Prema rezultatima iskopavanja sondi II-1958 i I-2018, sa sigurnošću se može pretpostaviti da je Gornja Tuzla pripadala kasnijem razvojnom periodu starčevačke kulture. Prije svega, to se odnosi na tamno slikanje po svijetloj podlozi, linearno i spiralno slikane keramičke fragmente, koji u kombinaciji sa kaneliranim barbotinom grube keramike i načinom pečenja, čine pouzdanu osnovu za izjednačavanje najstarijih starčevačkih elemenata Gornje Tuzle, sa završnim fazama starčevačke kulture, posebno ako se uzme u obzir da su već u stratumu VIa zabilježeni neki mlađi elementi. Prema Dimitrijeviću, slikana keramika Gornje Tuzle pripada fazi Spiraloid B,

\footnotetext{
118 Hronološke paralele ove rane faze u Galovu pronalaze se u većem broju naselja širom teritorija prostiranja starčevačke kulture, kao i na lokalitetu Donja Branjevina u Vojvodini čiji horizont II i početak horizonta I odgovaraju fazi Linear A (Karmanski 2005: 72).
} 
odnosno Starčevo III po Garašaninu. ${ }^{119}$ Ipak, sudeći prema malobrojnim fragmentima keramike sa slikanim motivima u poređenju sa ostalom mnogobrojnom keramikom, kao i na osnovu podatka da je spiralni ornament zabilježen na svega dva fragmenta, veoma je teško sa sigurnošću odgonetnuti kojoj fazi pripada starčevački sloj Gornje Tuzle. Gotovo svi pronađeni fragmenti slikane keramike, sa sva tri iskopavanja u Gornjoj Tuzli, imaju pravolinijske i geometrijske ornamente, izuzev jednog već navedenog fragmenta. To bi značilo da slikana keramika Gornje Tuzle više naginje fazi Linear B, ali imajući u vidu da nije istražen značajan dio naselja te da slikana keramika čini samo mali dio ukupnog inventara, kao i činjenicu da je starčevačka kultura u Gornjoj Tuzli prisutna u svojim finalnim fazama, imalo bi smisla da ona pripada nekoj mlađoj fazi, odnosno fazi degradacije starčevačke kulture. Važno je spomenuti i fragmenat sa polihromno slikanim ornamentom, zabilježen u stratumu VIa, za koji je utvrđeno da pripada mlađem periodu. Imajući u vidu sve navedeno, kao i najveći procenat grube keramike sa organizovanim barbotinom, može se pretpostaviti da starčevački slojevi Gornje Tuzle pripadaju fazi Spiraloid B, odnosno Starčevo III. Prema Dimitrijeviću, starčevački Spiraloid B karakteriše blaga bikonizacija i preuzimanje osnovnih elemenata rane vinčanske kulture, odnosno imitacija redukcijskog načina pečenja keramike, kao i postepeno smanjenje slikane keramike (Dimitrijević 1979: 258). Keramika iz sonde I-2018 pokazala je svega dva fragmenta slikane keramike, što se samo po sebi ne može uzeti kao relevantno s obzirom na veličinu sonde, ali pojava bikonizacije i sivocrne grube keramike pri gornjim sedimentima starčevačkog sloja pokazuje da su se pri kraju Starčeva dešavale određene promjene u načinu života. ${ }^{120}$ Dimitrijević je preuzimanje bikoniteta i tamne keramike protumačio kao odumiranje snage i kulturnog identiteta starčevačke kulture (Dimitrijević 1979: 258). Istina, na dosada istraženim površinama u Gornjoj Tuzli ne primjećuje se značajniji broj bikoničnih oblika posuda, ali sama činjenica da postoje uz tamnu keramiku govori o tome da je Gornja Tuzla naseljena relativno kasnije u odnosu na sjevernu Hrvatsku i Srbiju. Sam Čović je mlađi stratum VIa shvatio kao završnu fazu starčevačke kulture u širem smislu, a svoj stratum V okarakterisao ranovinčanskim u kojem se pojavljuju prvi oblici bikoniteta. ${ }^{121}$

Prema tome, najstariji elementi vinčanske kulture u Gornjoj Tuzli zabilježeni su u stratumu V koji je B. Čović shvatio kao neku vrstu prelazne faze između starijih starčevačkih i mlađih vinčanskih

\footnotetext{
${ }^{119}$ Dubravka Nikolić ističe kako je na prostoru Hrvatske i Srbije (a samim time i Bosne i Hercegovine) moguće pratiti samo dva razvojna stepena starčevačke kulture: Linear A i Spiraloid B prema Dimitrijeviću, odnosno Starčevo II i III prema Garašaninu (Nikolić 2005: 63).

${ }^{120}$ Ovakva hronološka sukcesija, odnosno preklapanje kasnog Starčeva i rane Vinče, pokazuje se na području Vinkovaca (Burić 2009b: 30).

${ }^{121}$ Najstariji sloj Varoši kod Koraja, prema Čoviću i Bencu, pokazao je identične nalaze sa stratumom V Gornje Tuzle, pa je uzet kao hronološki paralelan sloj. Time je naselje Varoš kod Koraja shvaćeno kao jedno od najstarijih naselja posve vinčanske kulture sjeveroistočne Bosne (Čović 1960-61: 115; Benac 1960-61: 61).
} 
karakteristika. ${ }^{122}$ Najvažniji lokalitet vinčanske kulture nalazi se u Srbiji, blizu Beograda, u naselju koje i danas nosi ime kao i lokalitet po kojem je ova kultura dobila ime - Vinča. Prema dosadašnjim rezultatima iskopavanja na ovom lokalitetu, gdje su zabilježeni najstariji slojevi, nastanak vinčanske kulture stavlja se u vrijeme oko 5300 godina pr. n. e., a njeno trajanje se pretpostavlja tokom narednih hiljadu godina (Burić 2014: 43). Hronologijom vinčanske kulture bavili su se mnogi autori, od kojih treba izdvojiti Miloja Vasića koji je prvi istraživao ovaj lokalitet početkom 20. stoljeća, Gordona V. Childea koji je uočio postojanje dvije faze Vinče, Friedricha Holstea koji je stratume podijelio na nivoe A-E (od kojih faze A-D pripadaju neolitskom periodu), Vladimira Milojčića i Milutina Garašanina čije se periodizacije uglavnom i danas koriste, zatim Josipa Korošca, Borislava Jovanovića i Stojana Dimitrijevića (Garašanin 1979b: 150). ${ }^{123}$ Prema Milojčiću, vinčanska periodizacija se dijeli na faze A-D, dok je faza B podijeljena na B1 i B2 (Garašanin 1979b: 151). S druge strane, Garašanin je ustanovio vertikalnu stratigrafiju Vinče na dubini od oko 6,5 m, pri čemu se fokusirao na pojavu novih odnosno izumiranje starijih karakteristika keramografije, te uveo termine Vinča-Tordoš za stariju fazu i Vinča-Pločnik za mlađu fazu (Garašanin 1973: 95). Garašanin je od Jovanovića prihvatio jednu prelaznu fazu, tzv. gradačačku fazu odnosno fazu nagle i značajne promjene. ${ }^{124} \mathrm{Na}$ Milojčićev rad oslonio se i Dumitru Berciu 1961. godine; on je također koristio faze A-D, oslanjajući se i na lokalitet Vinča-Belo Brdo i predloživši trodjelnu podjelu Vinča C faze. S druge je strane, Dimitrijević, koji se više oslanjao na zapadne dijelove Balkana, predložio drugačiju podjelu C i D faze, te po prvi puta podjelu Vinča D faze na D1 i D2 (Dimitrijević 1968: 89). Dalje raščlanjivanje vinčanskih faza predložio je Gheorghe Lazarovici 1979. godine, najviše se oslanjajući na lokalitet Vinča-Belo Brdo. Faza A podijeljena je na tri faze (A1, A2, A3), faza B također na tri faze (B1, B2 i B2/C), dok su faze C i D vraćene u prvobitnu periodizaciju (Lazarovici 1979: 76). ${ }^{125}$ Herman Parzinger je 1993. godine predložio drugačiju podjelu vinčanske kulture pokušavajući da je sagleda u cjelini zajedno sa tipologijom i radiokarbonskim datiranjem, te je izdvojio četiri faze, I-IV (Parzinger 1993: 273; Težak-Gregl 1997: 252 ). Već poznatu podjelu na AD faze prihvatio je i John Chapman 1981. godine, kojemu su faze A-C predstavljale stariju, a D mlađu fazu (Chapman 1981: 22). Nešto detaljniju i dosta podijeljeniju stratigrafiju pružio je

\footnotetext{
122 Stratum V sa svojim statusom prelazne faze mogao bi biti specifikum Gornje Tuzle s obzirom na to da se u samoj Vinči nalazi praznina između Starčeva i Vinče (Tasić, Marić, Bronk Ramsey, Kromer, Barclay, Bayliss, Beavan, Gaydarska, Whittle 2016a: 1-76; Tasić, Marić, Filipović, Penezić, Dunbar, Reimer, Barclay, Bayliss, Gaydarska, Whittle 2016b).

123 Milojčić i Garašanin pokušali su odrediti hronološki sistem vinčanske kulture u cjelini, sa njenim određenim fazama, posmatrajući materijal prema tipološkim kriterijima; Jovanović i Korošec su svoj hronološki sistem fokusirali na slojeve u samoj Vinči.

${ }^{124}$ Kasnije je usporedbom materijala sa drugim lokalitetima došlo do daljnje podjele ovih faza.

125 Pretpostavlja se da je novi talas naseljavanja vinčanske populacije zahvatio fazu C.
} 
Wolfram Schier: ona se sastoji od osam glavnih faza i nekoliko podfaza (Schier 1995: 251). Najnovija podjela Vinče krajem 20. stoljeća navela je Garašanina da redefinira svoju raniju podjelu, pa je 2000. godine dodao posljednju Vinča-Tordoš IIb 1-3 fazu.

Navedene periodizacije vinčanske kulture najvećim su se dijelom držale tiplogije keramičkih nalaza, pokušavajući da pronađu razlike i sličnosti na osnovu kojih bi se došlo do konkretnijih zaključaka. $\mathrm{Na}$ taj se način pokušalo doći do nekih relativnih datuma koji bi dali značajnije podatke o hronologiji i vremenu iz kojeg nalazi potiču. Zahvaljujući razvoju moderne tehnologije koja omogućava sinhronizaciju ranijih tipoloških podjela, baziranu na snažnim statističkim podacima mnogobrojnih radiokarbonskih datuma koji su u velikoj mjeri direktno povezani sa keramikom, omogućena je ispravnija tipološka podjela potkrijepljena apsolutnim datumima. U toku posljednje četiri decenije izvršeno je veoma mnogo radiokabonskih analiza koje su u značajnoj mjeri pomogle smještanju vinčanske kulture u period kojem pripada. ${ }^{126}$ Samo u toku 2009. godine Dušan Borić je donio rezultate 155 radiokabonskih datuma sa 27 različitih vinčanskih nalazišta. Njegovi rezultati pokazali su trajanje vinčanske kulture u periodu od 5400-5300. do 4650-4600 godina pr. n. e, dok je trajanje faza A-D ustanovljeno po $200 \pm 50$ godina (Whittle, Bayliss, Barclay, Gaydarska, Banffy, Borić, Drasovean, Jakucs, Marić, Orton, Pantović, Schier, Tasić, Vander Linden 2016: 8).

${ }^{126}$ Do 2016. godine izvršene su 564 radiokarbonske analize. 
Tabela 8. Periodizacija vinčanske kulture (Whittle, Bayliss, Barclay, Gaydarska, Banffy, Borić, Drasovean, Jakucs,

Marić, Orton, Pantović, Schier, Tasić, Vander Linden 2016: 3)

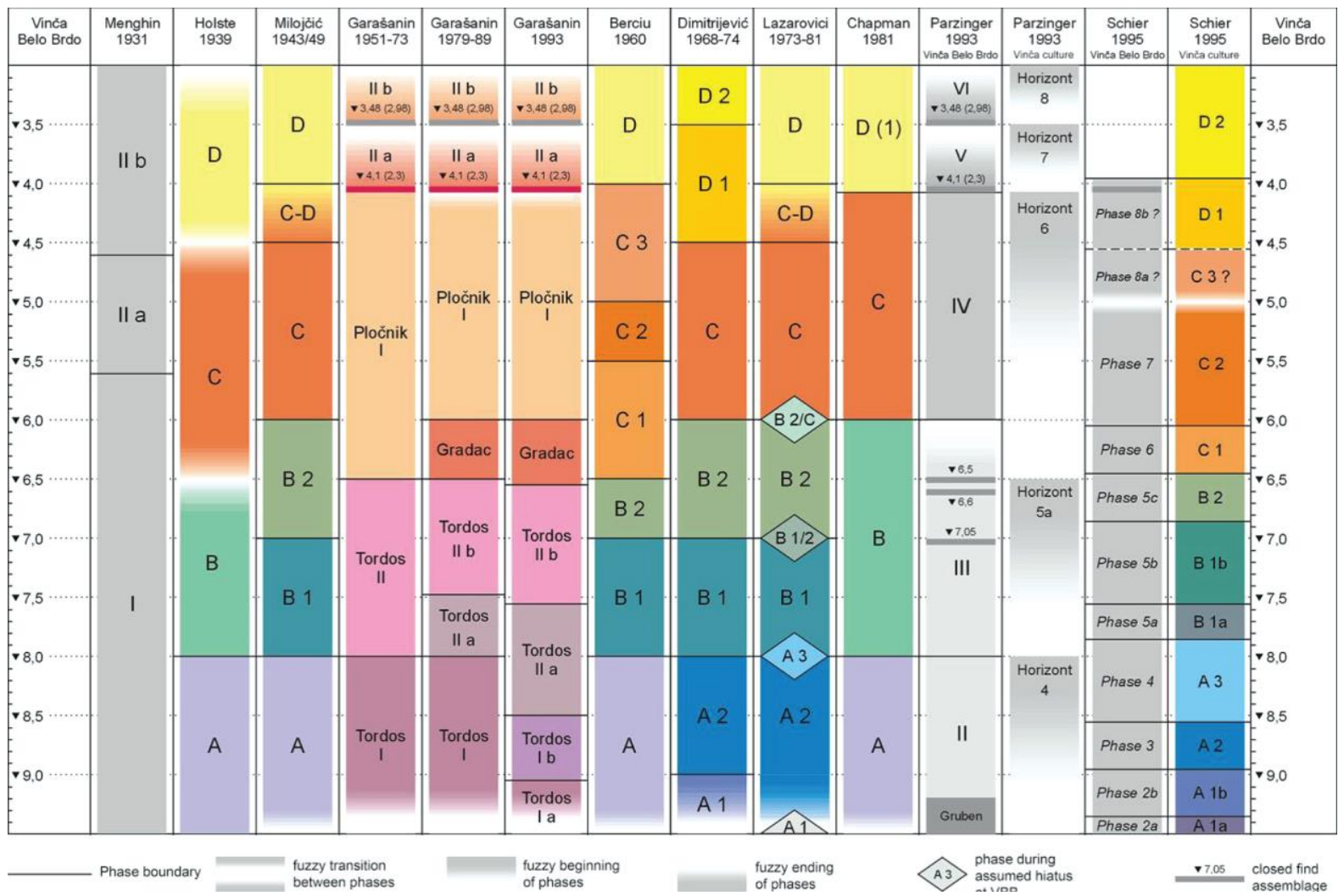

Danas je manje-više prihvaćena Milojčićeva podjela na A-D faze, pa će se pokušati navesti bitne karakteristike tih faza. Na osnovu mnogobrojnih radiokarbonskih datuma sa lokaliteta Vinča-Belo Brdo, ${ }^{127}$ koji su inkorporirani u već postojećih 600 datuma, poznato je da vinčanska kultura naseljava prostor Srbije tokom 52. stoljeća pr. n. e. i traje do kasnog 47. stoljeća pr. n. e. (Tasić, Marić, Filipović, Penezić, Dunbar, Reimer, Barclay, Bayliss, Gaydarska i Whittle 2016: 795). U radu, koji se bavi raznim hronološkim modelima i razvojem vinčanske kulture u jugoistočnoj Evropi, data je detaljna analiza cjelokupnog naselja vinčanske kulture sa slojevima, karakteristikama i datumima (Whittle, Bayliss, Barclay, Gaydarska, Banffy, Borić, Drasovean, Jakucs, Marić, Orton, Pantović, Schier, Tasić, Vander Linden 2016: 1-60). Prema istraživanju tih stručnjaka ustanovljeno je da faza Vinča A ima početke oko 5405-5310 godina pr. n. e (95\%), odnosno 5365-5320 pr. n. e (68\%). Ova faza je trajala do 5205-5070 godina pr. n. e (95\%), odnosno 5200-5130 pr. n. e (68\%). Prema tome, keramika faze Vinča A (Vinča-Tordoš I) trajala je od 125 do 295 (95\%) odnosno 140 do 230 godina (68\%). Period formiranja vinčanske kulture i njena prva proizvedena keramika ustanovljeni su u polovicu šestog milenija odnosno u toku 54. stoljeća pr. n. e., u čemu se slažu svi procesi istraživanja

${ }^{127}$ Izvršeno je oko 200 radiokarbonskih analiza. 
vinčanske i linearno-trakaste keramike na sjeveru. Faza Vinča B1 je, prema keramičkim nalazima i radiokarbonskim datumima, počela u periodu od 5335 do 5195 godina pr. n. e. (95\%) odnosno 53305245 pr. n. e. (68\%) i trajala do 5045-4800 godina pr. n. e. (95\%) odnosno 5040-4915 pr. n. e. (68\%). To bi značilo da je ova faza trajala od 185 do 505 (95\%) odnosno 230-395 godina (68\%). Prema tome, Vinča B1 trajala bi tokom 52. stoljeća pr. n. e., kada se primjećuje određeno preklapanje sa fazom A, a to razdoblje označava snažniji razvoj vinčanskih naselja koja su proizvodila keramiku karakterističnu za ovu fazu. Keramika faze Vinča B2 počela je sa proizvodnjom 5295-5105 godina pr. n. e. (95\%) odnosno 5285-5270 pr. n. e. (3\%) ili 5230-5130 pr. n. e. (65\%). Ostala je u upotrebi do 4920-770 godina pr. n. e. (95\%) odnosno 4905-4830 pr. n. e. (68\%). Keramika koja karateriše fazu Vinča B2 proizvođena je od 220 do 470 (95\%) odnosno 270405 godina (68\%). I ovi rezultati pokazuju preklapanje između keramike B1 i B2 faze, ali se primjećuje da je povećan broj naselja koja su proizvodila keramiku B2 faze. Prema dobivenim datumima, keramika koja pripada fazi B počela je da se proizvodi između 5360 i 5235 godina pr. n. e. (95\%) odnosno 5335-5275 pr. n. e. (68\%), a završila između 5050 i 4770 godina pr. n. e. (95\%) odnosno 5010-4825 pr. n. e. (68\%).

Naredna faza, Vinča C, ${ }^{128}$ prema dobivenim rezultatima počinje tokom 5115-4895 godina pr. n. e. (95\%) odnosno 5020-4905 pr. n. e. (68\%), a završava tokom 4620-4400 godina pr. n. e. (95\%) odnosno 4550-4445 pr. n. e. (68\%). To bi značilo da se keramika faze Vinča C proizvodila u trajanju od 350-650 (95\%) odnosno 390-555 godina (68\%). Većina datuma odgovara periodu trajanja faze Vinča C, izuzev nepreciznih analiza sa lokaliteta Belovode, Selevec i Gornja Tuzla koji produžuju Vinču C i nakon 4700 godina pr. n. e. Nije zabilježen porast lokaliteta koji su se bavili proizvodnjom keramike iz ove faze, u odnosu na B2 fazu. Faza Vinča D, prema rezultatima analiza, počela je u periodu između 4870 i 4725 godina pr. n. e. (95\%) odnosno 4810-4740 pr. n. e. (68\%), a završila u periodu između 4515 i 4360 godina pr. n. e. (95\%) odnosno 4490-4415 pr. n. e. (68\%), što bi značilo da je ova faza trajala od 250 do 455 (95\%) odnosno 285-390 godina (68\%). Prema navedenim datumima, očigledno je preklapanje faza C i D za period od oko 300 godina, što bi moglo da ukazuje na značajnu povezanost kulture u posljednjim stoljećima postojanja. Vinčanske faze A-D bi, na osnovu dobivenih datuma, trajale od polovine šestog do polovine petog milenija, odnosno od polovine 54. do polovine 45. stoljeća pr. n. e.. Najkraća faza bila je A, dok najduži period života predstavlja faza $\mathrm{C}$.

\footnotetext{
${ }^{128}$ Uočeno je i preklapanje B2 sa C fazom na pojedinim mjestima, što je datirano oko 4900 godina pr. n. e. (100\%).
} 
Sudeći prema pokretnim nalazima iskopanim u Gornjoj Tuzli može se reći da oni pripadaju istočnobosanskoj varijanti vinčanske kulture, koja se širi sa sjevera dolinom rijeke Drine prema jugu, što potvrđuju nalazišta oko Zvornika. Na ovom području sa sigurnošću je ustanovljeno postojanje vinčanske kulture s njenim karakteristikama, a najviše se ističu Gornja Tuzla i Varoš kod Koraja kao dva najistraženija lokaliteta na kojima je određena stratigrafska slika. Čović i Benac su utvrdili da najstariji sloj Varoši kod Koraja ima analogiju sa stratumom V Gornje Tuzle, idući na taj način do stratuma I Varoši koji bi bio jednak stratumu II Gornje Tuzle. Kada je u pitanju njihova usporedba sa vinčanskim slojevima, Čović je već dao određene karakteristike svakog stratuma koji je povezao sa Garašaninovim sistemom periodizacije, vežući npr. stratum V Gornje Tuzle sa početnom fazom Vinča- Tordoš, a mlađu fazu Gornje Tuzle sa mlađim fazama Vinče, Vinča-Pločnik. Danas je jasno da tipologija vinčanske keramike može i mora biti dublje razmotrena nego što su to ranije prihvatili mnogi autori koji su teškom mukom došli do definiranja faza kakve se i danas koriste. Ipak, u skladu sa trenutnim prihvaćenim modelima može se nešto jasnije definirati starost stratuma Gornje Tuzle u poređenju sa vinčanskim. Prema Čoviću, stratum V Gornje Tuzle hronološki se veže sa fazom Vinča-Tordoš I, odnosno fazom A.

Ukoliko se sagleda ovakva hronološka podjela, a sudeći prema veoma dobro razrađenoj tipologiji na lokalitetima Gornja Tuzla i Vinča, moguće je da ona ima dovoljno osnove da bude prihvaćena, u svakom slučaju imajući u vidu da bi trebala da se redefinira u skladu sa detaljnijom periodizacijom Vinče u budućnosti. Samim time, stratum V Gornje Tuzle hronološki je povezan sa stratumom IV Varoši kod Koraja, odnosno Vinča-Tordoš I / Vinča A, ${ }^{129}$ i ove dvije faze predstavljaju najstarije poznate slojeve vinčanske kulture u sjeveroistočnoj Bosni. One bi, dakle, prema hronološkim okvirima A faze trajale u vremenskom periodu između 5365-5320 i 5200-5130 godina pr. n. e., odnosno oko 190 godina. Time je lokalitet Varoš kod Koraja, sa svojom najstarijom fazom, na osnovu Benčeve analize smješten u hronologiju sjeveroistočne Bosne kao drugi najstariji lokalitet ovog područja. S druge strane, ovi datumi odgovaraju najstarijim nalazima vinčanskih elemenata $u$ Gornjoj Tuzli i starčevačku kulturu definiraju kao stariju od 54. stoljeća pr. n. e., kada otpočinje vinčanski period života. Stratum IV Gornje Tuzle imao je analogije sa stratumom III i prelaznim slojem III/II Varoši, koju je Benac hronološki povezao sa Vinča-Tordoš II fazom odnosno fazom B1 i djelomično B2. Što se tiče ostalih nalazišta sjeveroistočne Bosne, ova faza Varoši imala je svoje analogije sa najstarijim dijelovima lokaliteta Donja Tuzla, zatim s Lugom kod Goražda, stratumom II Matića i starijom fazom Korića hana. Prihvativši takvu povezanost, Čović je stratum IV Gornje

${ }^{129}$ Krajem 20. stoljeća Garašanin je nadopunio svoju hronologiju podijelivši Vinča - Tordoš na Tordoš Ia, Tordoš Ib, Tordoš IIa i Tordoš IIb, gdje je dodao Gradac kao prelaznu fazu, dok je faza Vinča-Pločnik ostala podijeljena na Pločnik I, Pločnik IIa i Pločnik II b. 
Tuzle hronološki usporedio sa mlađom Vinča-Tordoš fazom. Prema Garašaninu, faza Vinča-Tordoš II je trajala do prelaznog sloja dubine od 6,5 m u Vinči, dok je prema Milojčiću B faza trajala do šestog metra, a on ju je podijelio na dvije faze: B1 (8-7 m) i B2 (7-6 m). Prema nadopunjenoj Garašaninovoj periodizaciji, tadašnja Vinča-Tordoš II podijeljena je na Tordoš IIa i Tordoš IIb, sa trajanjem od 8 do 6,5 m dubine, što ponovo zahvata cijelu fazu B1 i polovinu B2. Imajući navedeno u vidu, prihvatit će se datumi B faze u cjelini, čiji se počeci datiraju od 5335-5275 godina pr. n. e. do 5010-4825 pr. n. e, što bi značilo da je B faza u cjelini trajala oko 450 godina. ${ }^{130}$ Ukoliko bi se prihvatila ranije ustanovljena tipologija prema kojoj su hronološki povezani lokaliteti sjeveroistočne Bosne, vidljivo je kako se na prelazu iz šestog u peti milenij dešava nešto veći proces naseljavanja ovog područja, što i karakteriše fazu B1 (Whittle, Bayliss, Barclay, Gaydarska, Banffy, Borić, Drasovean, Jakucs, Marić, Orton, Pantović, Schier, Tasić, Vander Linden 2016: 3).

Stratum III Gornje Tuzle odgovara stratumu II lokaliteta Varoši, za koji je u drugoj polovici 20. stoljeća ustanovljeno da ima hronološke paralele sa starijom fazom Gradine u Grbači i mlađom fazom Matića, te da se tipološki veže za fazu Vinča C (Benac 1960-61: 63). S druge strane, Čović je ustanovio da se materijal iz stratuma III Gornje Tuzle tipološki vezuje sa materijalom između 6. i 4. metra Vinče, odnosno fazom Vinča-Pločnik I koja je od početka ostala nepromijenjena. Vinča C je trajala između 5020-4905 i 4550-4445 godina pr. n. e., što bi značilo da je trajala oko 460 godina, čime je klasični period vinčanske kulture u Gornjoj Tuzli datiran u drugu polovicu petog milenija pr. n. e. - period za koji se pretpostavlja vrhunac života ovog lokaliteta. Ranije je navedeno kako se Vinča C i D preklapaju u vremenskom intervalu od oko 300 godina, što znači da međusobne razlike u keramografiji nisu značajno velike, odnosno da se elementi Vinče C zadržavaju kroz fazu D, a da elementi faze D imaju svoje začetke tokom faze C. Najmlađi vinčanski sloj Gornje Tuzle (stratum II) hronološki je povezan sa najmlađim slojem Varoši (stratumom I) za koji je utvrđeno da ima analogije sa mlađom fazom Gradine u Grbači, lokalitetom Dobrovac i mlađim periodom Korića hana. U poređenju sa Vinčom, stratum II Gornje Tuzle povezan je sa mlađom fazom Vinča-Pločnik (slojevi iznad 4 m), koju je Garašanin kasnije podijelio na Pločnik IIa i IIb, odnosno sa fazom Vinča D. Ova faza bi, dakle, trajala u periodu između 4810-4740 i 4490-4415 godina pr. n. e., što bi značilo da je postojala oko 325 godina.

Ovi datumi ujedno znače i završetak trajanja vinčanske kulture na prostoru centralnog Balkana, a samim time i na lokalitetu Gornja Tuzla na kojem se, sudeći prema nalazima iz posljednjeg metra, naselila eneolitska kultura koju Čović nije uspio sa sigurnošću hronološki odrediti. Time je, na

${ }^{130}$ Datumi pokazuju preklapanje stratuma V i IV Gornje Tuzle u trajanju od 145 godina. 
osnovu raspoloživih tipoloških vrijednosti i u kombinaciji sa radiokarbonskim datiranjem u širem području vinčanske kulture, okvirno ustanovljena hronološka slika trajanja mlađeneolitskih kultura sjeveroistočne Bosne. Kada je u pitanju lokalitet Gornja Tuzla, potrebno je malo detaljnije analizirati dosadašnje rezultate. Naime, Čović je iza sebe ostavio dva datuma. ${ }^{131}$ Jedan se odnosi na dio ugljenisane grede nađene u sondi II-1958 na dubini od 3,56 m, odnosno na početku stratuma III, čija je radiokarbonska analiza pokazala rezultate $5340 \pm 60$ godina, odnosno $3380 \pm 60$ godina pr. n. e. ${ }^{132}$ Drugi datum je ustanovljen na osnovu fragmenata ugljenisanog drva iz jame 5 u sondi I koja pripada starčevačkom periodu, čija je analiza pokazala rezultat od $6400 \pm 75$ godina, odnosno $4440 \pm 75$ godina pr. n. e (Čović 1960-61: 129). U fusnoti 165 Čović navodi kako su ovi rezultati neprihvatljivi jer se drastično razlikuju od relativne hronologije M. Garašanina, odnosno da je prvi datum 1.000 godina stariji od onoga koji se u to vrijeme smatrao tačnim. Ipak, u okvirima današnjih apsolutnih hronoloških odnosa između pojedinih vinčanskih razvojnih faza, ovi datumi su u potpunosti prihvatljivi. Rezultati drugog $\mathrm{C}^{14}$ datuma, iz najdubljeg stratuma VIb, smještaju starčevačke slojeve Gornje Tuzle u polovinu petog milenija prije nove ere, što Čović nije komentarisao ni kao ispravnim niti kao neispravnim drugim rezultatom, vjerovatno zbog slabije istraženosti ove kulture u tom periodu. Danas se, prema raspoloživim informacijama, može sa sigurnošću potvrditi da starčevački slojevi Gornje Tuzle, barem oni koji su dosad pronađeni (uz mogućnost postojanja starijih slojeva prema istoku i rijeci Jali), pripadaju završnoj fazi starčevačke kulture. Godine 2014. objavljen je novi rad koji govori o novim radiokarbonskim datumima neolitskih kultura Bosne i Hercegovine. Ondje se navodi kako su ranije definisana dva datuma ${ }^{133}$ koja se vežu za Starčevo (5674-5475 godina pr. n. e. odnosno 93,6\%) i Vinču (4534-4335. godina pr. n. e. odnosno 95,4\%) u Gornjoj Tuzli (Vander Linden, Pandžić, Orton 2014: 17). Zahvaljujući istraživanju sprovedenom od 2007. do 2009. godine i $\mathrm{C}^{14}$ analizi ugljena iz sonde I-2007, poznato je još nekoliko datuma. Ono što ipak predstavlja problem za bolju analizu ovih datuma jeste veoma štura dokumentacija koja ne navodi dubine slojeva iz kojih su uzeti uzorci. Najstariji nalaz OxA-23296 uzet je iz najnižih slojeva kontrolnog rova sonde I-2007 odnosno sa dubine od oko 2,70 m, i dao je rezultat od 5574-5482 godina pr. n. e. (75\%). Ovaj nalaz u potpunosti odgovara ranije navedenom, što bi starčevačku kulturu Gornje Tuzle smjestilo u polovinu šestog milenija prije nove ere. Uzorak OxA-23297 uzet je iz otkopnog sloja

\footnotetext{
131 Radiokarbonska analiza vršena je u Biološko-arheološkom institutu u Groningenu.

132 M. Burić je u sklopu svoje doktorske disertacije kalibrirao ove rezultate današnjim korekcijskim krivuljama, gdje je sigma 2 za ovo mjerenje 4330-4004 cal pr. n. e. (OxCal v. 4.0), za što je naveo kako izlazi van hronološkog okvira vinčanske kultre (Burić 2009: 43).

133 Ovi se datumi vjerovatno odnose na rekalibraciju (termini post quos) Čovićevih nalaza najnovijim krivuljama.
} 
$15^{134}$ koji je datiran u period od 5216-5011. godina pr. n. e. Iz osmog otkopnog sloja uzeta su dva uzorka, OxA-23298 (4786-4590 godina pr. n. e. odnosno 95,4\%) i OxA-23299 (4687-4502 godina pr. n. e. odnosno $95,4 \%$ ).

Prema rezultatima analize Instituta Vienna Environmental Research Accelerator iz marta 2008. godine, u najnovijem glasniku Muzeja Istočne Bosne u Tuzli objavljena su još dva datuma sa tih iskopavanja, a dobiveni datumi odgovaraju periodu trajanja vinčanske kulture na centralnom Balkanu. Prvi datum iz jame 14 iznosi $5735 \pm 35$ odnosno 4690-4490 godina pr. n. e. (95,4\%), a drugi datum iz jame 09 iznosi $5690 \pm 40$ odnosno 4690-4630 (4,7\%) i 4620-4440 godina pr. n. e. $(90,7 \%) .{ }^{135}$ Kalibriranjem ovih datuma 2019. godine primjećuju se neznate razlike-: prvi datum iznosi 4687-4496 (95,4\%), a drugi 4679-4450 godina pr. n. e. (95,4\%). Posljednja dva datuma vjerovatno su identični uzorci ranije spomenutih datuma, s obzirom na to da su rekalibriranjem iz 2019. godine dali rezultate identične onima iz 2014., uz to imajući u vidu da su oni pripremljeni tokom 2008., ali objavljeni tek 2017. godine. Dosad je, dakle, objavljeno pet datuma koji se vezuju za vinčanski period Gornje Tuzle, a od kojih samo dva imaju veze sa keramičkim nalazima. U pitanju su mjerenja na neidentifikovanom ugljenu koji se dovodi u vezu sa keramikom VinčaPločnik IIa odnosno Vinča C faze. Prvi datum iz ovog sloja (GrN-1974) donio je rezultat od 45354330 (95\%) odnosno 4460-4355 godina pr. n. e. (68\%), dok je drugi (Bln-349) datiran u 4780-4355 (95\%) odnosno 4685-4455 godina pr. n. e. (68\%). Od navedenih datuma, uporedo sa keramičkim nalazima sa provedenih iskopavanja, može se zaključiti da je starčevačka kultura naseljavala Gornju Tuzlu polovinom šestog milenija prije nove ere, a da su najraniji vinčanski elementi zabilježeni u periodu od 5216-5011 godina pr. n. e. i trajali do polovine petog milenija pr. n. e. odnosno do kraja vinčanske kulture u širem smislu. Prema navedenom, život neolitskog stanovništva Gornje Tuzle trajao je najmanje oko 1.000 godina, odnosno oko 360 godina za starčevačku i oko 750 godina za vinčansku kulturu, što dosada poznate granice starosti Gornje Tuzle kao najstarijeg neolitskog lokaliteta u Bosni pomjera sa oko 7.000 godina na oko 7.700 godina starosti.

\footnotetext{
134 Prema dokumentaciji sa ovog iskopavanja, iskopano je 18 slojeva nakon čega se krenulo u vertikalno spuštanje kontrolnog rova iz kojeg je uzet prvi uzorak.

135 Kopija rezultata analize koju je proveo Institut iz Beča nalazi se među dokumentacijom sa iskopavanja provedenog 2007.-2009. godine u Muzeju Istočne Bosne u Tuzli.
} 


\section{5a Zaključna razmatranja}

Neolit Bosne i Hercegovine je u značajnoj mjeri zavisio od okolnih zemalja odakle su dopirali razni kulturološki uticaji. Ti su uticaji primjetni u sve tri zone, od kojih je hercegovački predio zavisio od jadranskih uticaja, centralni dio bio je zona ispreplitanja uticaja sa sjevera i juga, u sjevernom odnosno sjeveroistočnom dijelu dominirale su bliskoistočne kulture. Najstariji tragovi neolita u Bosni i Hercegovini pronađeni su na području Hercegovine, odnosno na pećinskim lokalitetima gdje se iz mezolitskih supstrata razvijaju neolitske sjedilačke privredne kulture, kakav je slučaj bio i na istočnojadranskoj obali. Te su kulture bile pod snažnim uticajem nosilaca impresso kulture koji su, najvjerovatnije dolinom rijeke Neretve, naselili ove prostore, što najbolje pokazuje keramika, odnosno nedostatak kardium impresso keramike u Hercegovini. Tokom srednjeg i mlađeg neolita prostor Hercegovine je ostao pod uticajem sa jadranske obale, kada dolazi do razvoja danilske kulture iz vremena srednjeg neolita te hvarsko-lisičićke kulture iz mlađeg perioda. Nosioci impresso kulture prodrli su, najvjerovatnije dolinom rijeke Bosne, dublje u unutrašnjost naselivši lokalitet Obre I u centralnoj Bosni. Na ovom su lokalitetu pored impresso keramike pronađeni i tragovi života starčevačke kulture sa materijalom identičnim onome u Gornjoj Tuzli, koja je bila dominantija u odnosu na impresso keramiku. Na osnovu materijala iz dva najdublja stratuma naselja Obre I može se sa sigurnošću reći da je ovaj lokalitet najstariji u centralnoj Bosni i da pripada drugoj polovici srednjeg neolita. Mlađi stratumi ovog lokaliteta ranije su pripisani kakanjskoj kulturi, čija izolovana pojava kao zasebne kulture više nije prihvaćena s obzirom na hronološke i keramografske konfrontacije. Prema tome, stratumi III i IV naselja Obre I, I. faza Okolišta, Arnautovići, Kakanj, Plandište i Tuk predstavljaju prelaznu fazu u procesu formiranja butmirske kulture, koja je definisana terminom protobutmirska faza, odnosno faza Protobutmir Ia paralelna sa Obre I/III, te Protobutmir Ib paralelna sa Obre I/IV.

Sjeveroistočna Bosna svoj je procvat doživjela tek sa kasnim neolitom kada se pod uticajem vinčanske kulture razvio veliki broj naselja. Ipak, elementi srednjeneolitske kulture konstatovani su u najdubljim slojevima lokaliteta Gornja Tuzla, pa se ovaj lokalitet ističe kao najstariji u ovom dijelu zemlje. Tokom radova na gradskom trgu u Tuzli iznesen je zaključak da su pronađeni elementi starčevačke kulture, što je potvrdila i arheologinja Kujundžić- Vejzagić. No, na osnovu uvida u materijal sa ovog lokaliteta, deponovanog u Muzeju Istočne Bosne, tragovi starčevačke kulture nisu 
uočeni, iako je teško iznijeti konkretniji zaključak jer veoma velik broj nalaza nije signiran, a dokumentacija je u potpunosti beskorisna. Ipak, imajući u vidu da je centar Tuzle bio naseljen u kasnom neolitu, nije nemoguće pretpostaviti da su se starčevački stanovnici Gornje Tuzle tokom nekog perioda spustili dolinom rijeke Jale prema ravnijem terenu. Poznato je i da se na ovom prostoru kasnije razvio rudnik soli, što je moglo privući pripadnike starčevačke kulture, ali sudeći po geološkim analizama rude soli bile su dosta dublje u zemlji u odnosu na površinsku kamenu sol u Gornjoj Tuzli. Nažalost, veliki dio ovog lokaliteta uništen je modernim radovima, pa je teško očekivati da se dođe do konkretnijih zaključaka. Pored Gornje Tuzle i potencijalno Donje Tuzle, na prostoru sjeveroistočne Bosne dosada nisu pronađeni tragovi starčevačke kulture, pa se tako ovaj prostor definira kao dominatno pod uticajem bliskoistočne vinčanske kulture. S druge strane, na prostoru Hrvatske konstatovan je veoma veliki broj naselja starčevačke kulture sa najranijim Linear A slojevima, dok su u Gornjoj Tuzli utvrđeni nalazi iz mlađih perioda, što bi značilo da prostor sjeveroistočne Bosne u starijim fazama starčevačke kulture nije bio naseljen neolitskim kulturama. Od ranije je poznato da se mlađeneolitska vinčanska kultura javlja na istim lokalitetima koji su bili naseljeni srednjenolitskom starčevačkom kulturom, što je bio slučaj i sa Gornjom Tuzlom. Ipak, ostala naselja sjeveroistočne Bosne razvila su se tek sa dolaskom nosilaca vinčanske kulture. Ova kulturna grupacija, koja pripada periodu mlađeg neolita na prostoru centralnog Balkana, migrirala je sa jugoistoka prema sjeverozapadu tokom dugog vremenskog perioda. Pretpostavlja se da je Jugoistočna Evropa zapadna provincija bliskoistočne kulture zemljoradnika, odnosno neka vrsta kolonije koja ipak nije imala svrhu identičnu kolonijama iz mlađeg antičkog perioda. U odnosu na starije neolitske kulture, vinčanska je okarakterisana kao kultura značajnih novina u svakom aspektu života. Za razliku od starčevačke koja je naselila značajan dio istočne Hrvatske, vinčanska kultura je na ovom prostoru utvrđena samo na jednom lokalitetu - Bapska-Gradac, dok je prostor sjeveroistočne Bosne bio ispunjen vinčanskim lokalitetima.

Sjeveroistočna Bosna obiluje rijekama i uzvišenjima te plodnom i bogatom zemljom, što je zadovoljilo osnovne potrebe za odabir lokacije gdje će se podignuti naselje. Ipak, navedene karakteristike nisu strane Balkanu, što su shvatili nosioci starčevačke kulture kojima ovaj prostor nije bio zanimljiv. Ipak, nakon otkrića bogatih naslaga soli u tuzlanskom bazenu starčevačke su zajednice naselile područje Gornje Tuzle koje je imalo sve neophodne geografske odlike - rijeku, zemlju, šume itd., ali i rudu soli. Istraživanjem uloge soli kod neolitskih zajednica dobila se jedna nova percepcija, barem kada su u pitanju starčevačke zajednice koje su poznate po tome što su naseljavale prostore bogate rudama soli, što je najbolje demonstrirao N. Tasić koji je kartirao ranoneolitska nalazišta i uporedio ih sa poznatim naslagama soli. Tuzlanski bazen odlikuje veoma složena 
geološka građa, koja je rezultirala formiranjem sonih formacija nakon povlačenja marinskih sedimenata starog mora. S otkrićem mikroforaminifera u sonoj formaciji na izdancima kod Gradine u Tuzli usaglašeno je da solna formacija tuzlanskog bazena ima morsko porijeklo, iz vremena srednjeg miocena odnosno donjeg badena. Danas na području Tuzle postoje dva aktivna rudnika soli, od kojih je jedan u neposrednoj blizini lokaliteta Gornja Tuzla, tj. na području Tetime koja se nalazi sjevernije u odnosu na lokalitet. Mineraloškim ispitivanjem soli u ležištu Tetima utvrđena je sol krupnozrnog agregata, tipična za halit (kamenu sol), koja se veoma često nalazila blizu površine te se na taj način neolitskim zajednicama olakšavala njena ekspolatacija. Sol je, dakle, za neolitske stanovnike Gornje Tuzle imala ključnu ulogu pri formiranju naselja omogućivši im višemilenijsku ekspolataciju koja traje od najranijih vremena do danas, kada rudnik Tetima i dalje crpi naslage ovog veoma vrijednog i značajnog minerala.

Zahvaljujući bogatim rudnim zalihama soli i starčevačkoj tradiciji naseljavanja na prostore takvih karakteristika, Gornja Tuzla predstavlja jedno od najstarijih naselja Bosne i Hercegovine, koje je istraživano u nekoliko navrata. Prvi koji je otvorio sonde na ovom lokalitetu bio je Borivoj Čović, koji je istraživao u vremenskom periodu od 1955.-1958. godine i ustanovio kompletnu stratigrafiju ovog lokaliteta, kopajući do 5,50 m dubine na kojoj je pronađena zdravica. Zahvaljujući opsežnom istraživanju koje je trajalo preko mjesec dana i rezultatima do kojih je Čović došao, poznato je da starčevački slojevi Gornje Tuzle predstavljaju zrelu fazu njenog razvoja koja pripada drugoj polovici srednjeg neolita. Iskopavanje provedeno 2007.-2009. godine izuzetno je značajno zbog radiokarbonskih datuma iz vinčanskih slojeva čiji su rezultati dodatno utvrdili starost ovog lokaliteta. Ipak, zbog veoma šture dokumentacije i nesigniranog pokretnog materijala, uz činjenicu da sonda nije iskopana do zdravice (izuzev kontrolnog rova za koji se ne znaju tačne dubine), iz spomenutog je iskopavanja veoma teško izvući konkretnije zaključke. S druge strane, istraživanje provedeno 2018. godine pokazalo je južnu granicu rasprostiranja lokaliteta i dodatno utvrdilo postojanje starčevačkih slojeva sa slikanom keramikom koja je očigledno pokrivala veoma širok prostor. Ranije je pretpostavljeno da se naselje širi na istok i jug dolinom rijeke Jale, ali je ovim istraživanjem ustanovljena južna granica, dok istočna ostaje upitna ponajviše zbog nedostatka finansija potrebnih za ozbiljnije istraživanje s obzirom na dubinu kulturnog sloja, ali i gustu naseljenost lokalnog stanovništva.

Analizirajući keramiku sa svih navedenih iskopavanja, važno je istaknuti ozbiljnost kojom je Čović pristupio iskopavanju i procesuiranju nalaza, pa se njegovi rezultati mogu prihvatiti i danas. Primjetan je klasični period starčevačke kulture sa grubom barbotin, finom monohromnom te uglavnom linearno i manje spiraloidno ukrašenom slikanom keramikom na kojoj se može ustanoviti 
postepeni i spori prelaz u mlađu vinčansku keramiku. Nju s druge strane karakteriše crnoglačana kanelirana fina keramika, ali i zadržavanje starčevačkih elemenata do kraja te faze. Klasične velike grube konusne posude, ukrašene horizontalnim i vertikalnim trakama (kanelurama) po zidovima i utiskivanjem prstiju po obodu, u kojima se čuvala so, zadržale su se kroz cijeli period trajanja vinčanske kulture. Istina, faktura ovih posuda puno je bolje kvalitete u mlađim periodima u odnosu na starije, ali se upotreba zadržala od najranijih slojeva, što pokazuje mirnu tranizciju i ponajviše praktičnu narav stanovnika ovog naselja, koji su živjeli mirnim industrijskim životom. Postavlja se pitanje koliko je dugo trajao neolitski period Gornje Tuzle, odnosno kada su se naselili nosioci starčevačke kulture i do kada je trajala vinčanska faza ovog naselja, koju su naslijedile mlađe eneolitske kulture. Periodizacija starčevačke kulture uglavnom se zasniva na slikanim ornamentima, bojenim bijelom ili crvenom bojom, s motivima raznih geometrijskih oblika. Ni na jednom fragmentu nije ustanvoljeno slikanje bijelom bojom koje karakteriše stariju fazu Linear A zastupljenu na prostoru istočne Hrvatske, pa se prema tome može uočiti da je Gornja Tuzla mlađa od naseljā starčevačke kulture istočne Hrvatske. Najveći broj fragmenata dobivenih u sva tri iskopavanja ima pravilan geometrijski oblik, ali je ustanovljeno nekoliko spiraloidnih fragmenata, kao i jedan polihromni. To bi značilo da Gornja Tuzla ponajviše naginje fazi Spiraloid B, ali zbog veoma male istražene površine u odnosu na poznatu površinu naseljenu za vrijeme Starčeva ekstremno je teško odgonetnuti njenu pripadnost u periodizaciji slikane keramike.

Sa stratumom V Gornje Tuzle otpočinje novi život - na keramici se vide uticaji vinčanske kulture, dolazi do bikonizacije posuđa i javljanje prvih oblika tamno pečene keramike u njenim najranijim grubim sivocrnim oblicima. Periodizacijom vinčanske kulture bavilo se veoma mnogo arheologa, ali se danas uglavnom koristi Milojčićeva podjela na faze A-D. U Gornjoj Tuzli su evidentirane sve karakteristike ovih faza, pa se može reći da je vinčanska kultura ovdje prisutna tokom svog cjelokupnog perioda trajanja. Radiokarbonskim analizama omogućeno je bliže datiranje faza vinčanske kulture i njihovo hronološko određivanje. Ustanovljeno je da vinčanska kultura traje oko 1.000 godina, sa početkom od polovine 6. do polovine 5. milenija pr. n. e., te da navedene faze traju po 200 \pm 50 godina. Najstarija faza A vinčanske kulture, odnosno stratum V Gornje Tuzle, trajala je od oko 5405-5310 (95\%) odnosno 5365-5320 godina pr. n. e. (68\%). Ipak, ovi se datumi ne mogu sa sigurnošću uzeti za početke vinčanskog života u Gornjoj Tuzli, posebno kada se uzme u obzir da sam lokalitet Vinča-Belo Brdo traje od 52. do 47. stoljeća prije nove ere. Finalna faza D, odnosno stratum II Gornje Tuzle, završila je u periodu između 4515-4360 (95\%) odnosno 4490-4415 godina pr. n. e. (68\%). Kada je u pitanju lokalitet Gornja Tuzla, objavljeno je nekoliko datuma koji bi starčevačku kulturu smjestili u polovinu šestog milenija prije nove ere, a uz vinčanski period Gornje 
Tuzle vezuje se pet datuma od kojih su samo dva vezana uz keramičke nalaze. Prema rezultatima tih datuma, najraniji vinčanski elementi Gornje Tuzle zabilježeni su u periodu od 5216-5011 godina pr. n. e. i trajali su do polovine petog milenija pr. n. e., tj. do 4535-4330 (GrN-1974) (95\%) odnosno 4460-4355 godina pr. n. e. (68\%). Na osnovu rezultata radiokarbonske analize može se reći da je neolitički period u Gornjoj Tuzli trajao oko 1.000 godina, a da život u nepreknutom kontinuitetu traje i danas. 


\section{5b Bibliografija}

Aranđelović-Garašanin, D. 1954. Starčevačka kultura, Ljubljana.

Arheološki Leksikon, Tom I, Sarajevo, 1988

Arheološki Leksikon, Tom II, Sarajevo, 1988

Babajić, E., Mandžić, K., Salihović, S. 2011. Mafitni ekstruzivi Papratnice kod Žepča kao tehnički građevinski kamen, u: Zbornik radova IV, Savjetovanje geologa Bosne i Hercegovine, Sarajevo, 6675.

Bakalović, M. 2017. Neolitska naselja na području sjeveroistočne Bosne, $\check{C} G T, X X$, Tuzla, 83-101.

Baraković, A. Opća geologija, Ars Grafika, Tuzla, 2007

Batović, Š., 1979. Jadranska zona, u: Praistorija jugoslavenskih zemalja II: Neolitsko doba, Akademija nauka i umjetnosti Bosne i Hercegovine, Sarajevo, 471-634.

A. 1949/50. Istraživanja prehistorijskih nalazišta u dolini Bile, GZM, N. S. sv. IV-V, Sarajevo, 5-44.

Benac, A. 1953. , Neolitsko naselje u dolini Bile (Rezultati istraživanja u 1951. godini), GZM, N. S. sv. VIII, Sarajevo, 237-263.

Benac, A. 1954. Prethodna istraživanja na neolitskom naselju u Lisičićima, GZM, N.S. sv. IX, Sarajevo, 137-161.

Benac, A. 1955. Neolitsko naselje u Lisičićima kod Konjica, GZM, N. S. sv. X, Sarajevo, 49-77.

Benac, A. 1956. Osnovna obilježja neolitske kulture u Kaknju, GZM, N.S. sv. XI, Sarajevo, 167-182.

Benac, A. 1958. Građevinska djelatnost u prehistoriskom naselju Varoš kod Koraja, ČGT, II, Tuzla, $5-20$.

Benac, A: 1959. Dvije neolitske stanice kod Goražda, ČGT, III, Tuzla, 55-64.

Benac. A 1960. Neolitski telovi u sjeveroistočnoj Bosni i neki problemi bosanskog neolita, GZM, $N$. S. sv. XV-XVI, Sarajevo, 39-78.

Benac, A. 1960/61. Neolitski telovi u sjeveroistočnoj Bosni i neki problemi bosanskog neolita, GZM, N.S. sv.XV-XVI, Sarajevo, 39-78

Benac, A. 1963. Odnosi Bosne sa srednjom Evropom u neolitskom dobu, GZM, N. S. sv. XVIII, Sarajevo, 25-39. 
Benac, A. 1971. Obre II. Neolitsko naselje butmirske grupe na Gornjem Polju, GZM, N. S. sv. XXVI, Sarajevo, 5-299.

Benac, A. 1972/73. Neolitsko naselje starčevačko- impresso i kakanjske kulture na Raskršću, GZM, N. S. sv. XXVI / XXVIII, Sarajevo, 5- 171.

Benac. A 1979. Prelazna zona, u: Praistorija Jugoslavenskih zemalja II: Neolitsko doba, ANU BiH, Sarajevo, 363-473.

Benac, A., Garašanin, M., Srejović, D. Uvodna razmatranja, u: Praistorija Jugoslavenskih zemalja II: Neolitsko doba, ANU BiH, Sarajevo, 9-11.

Brukner, B. 1974. Praistorija Vojvodine, Monumenta Archaeologica I, Novi Sad, 1-152

Brukner, B. 1976. Prilog proučavanju veza Bosne i jugoslovenskog Podunavlja u neolitu, ANU BiH kn. XIII, CBI, XI, Sarajevo, 45-59.

Budja, M. 2012. The Transition to farming and the „revolution“ of symbols in the Balkans. From ornament to entoptic and external symbolic storage, Documenta Praehistorica XXXI, Ljubljana, 5981.

Budja, M. 2014. Neolitizacija Evrope: arheološka, arheogenetička i biomolekularna perspektiva, u: Darovi zemlje, Neolitik između Save, Drave i Dunava, Balen, J., Hršak, T., Šošić Klindžić, R. (ur.), Arheološki muzej u Zagrebu; Muzej Slavonije Osijek; Filozofski fakultet Sveučilišta u Zagrebu, 106-129.

Burić, M. 2009b. Vinčanska kultura i njezin uticaj na neolitik istočne Hrvatske, nepublicirana doktorska disertacija, Filozofski fakultet u Zagrebu.

Burić, M., 2014. Vinčanska kultura, u: Darovi zemlje, Neolitik između Save, Drave i Dunava, Balen, J; Hršak, T; Šošić-Klindžić, R (ur.), Arheološki muzej u Zagrebu, Muzej Slavonije Osijek, Filozofski Fakultet, Zagreb.

Cavruc, V. 008. The Present Stage of the Researches regarding Prehistoric Salt Production in the Carpatho-Danubian Region, ANGVSTIA, 12, 79-90.

Chapman, J. 1981, The Vinča Culture of South-East Europe: Studies in Chronology, Economy and Society, Oxford: British Archaeological Report, International Series 117.

Chapman, J. 1988. Ceramic production and Social Differentation: The Dalmatian Neolithic and the Western Mediterranean, Journal od Mediterranean Archaeology 1, 3-25. 
Childe, G. 1929. The Danube in Prehistory, At the Clarendon press, Oxford.

Čičić, S., Jovanović,Č., Mojičević, M., Tokić, S. 1991. Tumač za list OGK Tuzla 1:100000. Savezni geološki zavod Beograd, 1991, 1-72.

Čičić, S., Redžepović, R., 2005. O naučnom naslijeđu u geologiji Bosne i Hercegovine, $R G G F$, Tuzla.

Čović, B. 1960/61. Rezultati sondiranja na preistoriskom naselju u Gornjoj Tuzli, GZM, N.S. sv.XVXVI, Sarajevo, 79-139.

Čurčič, V. 1908. Prehistoričke utvrde oko Sarajeva, GZM XX, knj. III, Sarajevo, 363-381.

Dimitrijević, S., 1968. Sopotsko-lenđelska kultura, Arheološki institut Filozofskog fakulteta Sveučilišta u Zagrebu, Zagreb.

Dimitrijević, S. 1974. Problem stupnjevanja starčevačke kulture s posebnim obzirom na doprinos juţnopanonskih nalazišta rešavanju ovih problema. u: Počeci ranih zemljoradničkih kultura $u$ Vojvodini i srpskom Podunavlju. Materijali X, Beograd, 39 - 76.

Dimitrijević, S., 1979. Sjeverna zona, u: Praistorija jugoslavenskih zemalja II: neolitsko doba, Benac, A. (ur.), Akademija nauka i umjetnosti Bosne i Hercegovine, Centar za balkanološka ispitivanja, Sarajevo. 229-360

Dautbegović, A. 1988. Spomenica stogodišnjice rada zemaljskog muzeja Bosne i Hercegovine, 18881988, Zemaljski muzej Bosne i Hercegovine, Michigen University

Fiala, F. 1892. Pretraživanje pećina u Bosni, GZM, god. IV, knj. III, Sarajevo, 237-243.

Garašanin, M. 1973. Praistorija na tlu Srbije, Beograd.

Garašanin, M. 1979. Centralnobalkanska zona, Praistorija jugoslavenskih zemalja II: Neolitsko doba, Akademija nauka i umjetnosti Bosne i Hercegovine, Sarajevo, 79-213.

Garašanin, M. 1979b. Vinčanska grupa, u: Benac, A. (ed.), Praistorija jugoslavenskih zemalja II, Sarajevo, 144-207.

Hadžimustafić, E., Suljić, A., Baraković, A. 2007/08. Morfostrukturne odlike sliva rijeke Soline, Zbornik radova Prirodno-matematičkog fakulteta Univerziteta u Tuzli, IV, Tuzla, 211-218.

Hofmann, R., Kujundžić- Vejzagić, Z., Müller, J., Rassmann, K., Müller- Scheessel, N. 2009. Rekonstrukcija procesa naseljavanja u kasnom neolitu na prostoru centralne Bosne, GZM N. S. L/LI, Sarajevo, 11-179. 
Isabegović, J. 2011. Potencijal ugalja žepačko-novošeherskog basena na primjeru ležišta „Brezove Dane“, : Zbornik radova IV, Savjetovanje geologa Bosne i Hercegovine, Sarajevo, 479-494.

Kaljanac, A. 2013. Arheološka istraživanja etnogenetskih procesa u prahistoriji zapadnog Balkana: mogućnosti i ograničenja, $A N U B i H, C B I, X X X X I I$, Sarajevo, 45-71.

Kaljanac, A. 2016. Rezultati arheološke prospekcije 2016. godine na lokalitetu Butmir, ANU BiH, CBI kn. XXXXVI, Sarajevo, 19-43.

Karmanski S., 2000. Donja Branjevina, monografija, Odžaci.

Karmanski, S., 2005. Donja Branjevina: A Neolithic settlement near Deronje in the Vojvodina (Serbia), Societa per la Preistoria e Protoistoria della regione Friuli- Venezia Giulia, Quaderno 10, Trieste, 1-79.

Katzer, F. 1926. Geologija Bosne i Hercegovine, Direkcija državnih rudarskih preduzeća, Sarajevo. Kosorić, M. 1967. Neolitsko naselje u selu Batkoviću kod Bijeljine, ČGT, VII, Tuzla, 21-29.+

Kosorić, M. 1970. Rezultati zaštitnog iskopavanja na lokalitetu Brdo u Donjoj Mahali kod Orašja, $\check{C} G T$, VIII, Tuzla, 41-45.

Kosorić, M. 1970. Neolitsko naselje na lokalitetu Dobrovac, ČGT, VIII, Tuzla, 9-15.

Kosorić, M. 1972. Sondažno rekognisciranje lokaliteta Korića Han u Gračanici, $\check{C} G T, I X$, Tuzla, 5-9. Kosorić, M. 1980. Praistorijska naselja na području Spreče, ČGT, XIII, Tuzla, 103-117.

Kosorić, M. 1990. Praistorijsko naselje Dvorišta u Drinjači, GZM, N. S. sv .XXXXV, Sarajevo, 27-34. Kudumović- Dostović, F., 2017. Sjveroistočna Bosna (Geografska morfologija), Geografsko društvo Tuzlanskog kantona, Tuzla.

Kujundžić- Vejzagić, Z., Müller J., Rassman, K., Schüler, T. 2004. Okolište- Iskopavanje i geofizička prospekcija centralnobosanskog tel-naselja iz prve polovine petog milenija p.n.e., $A N U$ BiH kn. XXXIII, CBI XXXI, Sarajevo, 13-33.

Kujundžić- Vejzagić, Z. 2008. Prilog proučavanju rane metalurgije u centralnoj Bosni, ANU BiH kn. $X X X V I I, C B I X X X V$, Sarajevo, 23-47

Kujundžić-Vejzagić, Z., Lippert, A., Tiefengraber, G., Bakalović, M. 2017. Neolithic and chalkolithic setllement. Research in north-eastern Bosnia. The austro-bosnian excavation project in 
Gornja Tuzla: Some texts for the preliminary report on the first excavation campaign at Gornja Tuzla in October 2007, ¿̌GT, $X X$, Tuzla, 147-154.

Lazarovici, G. 1979. Neoliticul Banatului. Bibliotheca Musei Napocensis, 4. Cluj-Napoca.

Lepirica, A., 2012. Reljef Bosne i Hercegovine, Zbornik radova departmana za geografiju, turizam i hotelijerstvo 41, Tuzla, $1-17$.

Mandić, M. 1926. Prehistoriske i sredovječne utvrde oko Travnika, GZM, XXXVIII, Sarajevo, 35-43.

Mandić, M. 1927. Rezultati otkapanja neolitskog naselja u Donjoj Mahali kod Orašja na Savi. Broncani nalaz u Novom Gradu kod Bos. Šamca, GZM, XXXIX, sv. II, Sarajevo, 199-206.

Mandić, M. 1939. Prethodni izvještaj o započetom iskapanju u Hrustovačkoj pećini kod Bos. Vrpolja, GZM, LI, sv. I, Sarajevo, 65-71.

Marijanović, B. 1978. Nova nalazišta impreso- kulture u Hercegovini, GZM, n.s., A, XXXIII, Sarajevo, 5-21.

Marijanović, B. 1981. Ravlića pećina, GZM, N.S. XXXV-XXXVI, Sarajevo, 1-97.

Marijanović, B. 1983. Prilog proučavanju ekonomike starijeg neolita Hercegovine, GZM N.S. XXXVIII, Sarajevo, 65-72.

Marijanović, B. 2006. Neka pitanja ranog neolitika Jadrana, Archaeologia Adriatica I, Zadar, 7-54.

Marijanović, B. 2008. Pintaderad iz Ravlića Pećine, Archaeologia Adriatica II, Zadar, 141-149.

Marijanović, B. 2009. Crno Vrilo 1, Sveučilište u Zadru, odjel za arheologiju, Zadar.

Marijanović, B. 2000. Prilozi za prapovijest u zaleđu jadranske obale, Filozofski fakultet u Zadru, odsjek za arheologiju, Zadar.

Marijanović, B. 2012. Ravlića pećina. Prapovijesno naselje. Nacionalna i univerzitetska biblioteka Bosne i Hercegovine, Sarajevo

Marijanović, B. 2013. Prilog strategiji istraživanja neolitika na jadranu, Archaeologia Adriatica VII, Zadar, 77-94.

Milić, V., Kulenović, S., Panjević, N. Solarstvo u Tuzli od prahistorije do danas, Tuzla.

Milojčić, V. 1949. Chronologie Der Jüngeren Steinzeit Mittel Und Südosteuropas, Berlin. 
Minichreiter, K. 2006. New radiocarbon dates for the early Starčevo culture in Croatia, Prilozi Instituta za Arheologiju, vol 23, Zagreb, 5-16.

Minichreiter, K. 2007. Slavonski Brod Galovo, deset godina arheoloških istraživanja, Institut za arheologiju, Zagre

Minichreiter, K. 2007b, Bijelo slikani linear A stupanj starčevačke kulture u Hrvatskoj, Prilozi Instituta za arheologiju u Zagrebu, vol. 24, Zagreb, 21-34

Minichreiter, K., 2010. Nadzemni objekti u naseljima starčevačke kulture / Above-ground Structures in the Settlements of the Starčevo Culture, Prilozi Instituta za arheologiju u Zagrebu, 27: 15-32.

Mušović, A. 2010. Arheološko istraživanje lokaliteta „Trg slobode" u Tuzli, u: Baština sjeveroistočne Bosne, 1, Zavod za zaštitu i korištenje kulturno historijskog i prirodnog nasljeđa Tuzlanskog kantona, 100- 117.

Nuhanović, S. 2010. Izgradnja višenamjenskih bušotina u ležištima soli, doktorska disertacija, Univerzitet u Tuzli.

Nikolov, V. 2012. Salt, early complex society, urbanization: Provadia-Solnitsata (5500-4200 bC), Salt and Gold: The Role of Salt in Prehistoric Europe, Provadia, Veliko Tarnovo, 11-65.

Nikolić, D. 2005. The development of pottery in the middle Neolithic and chronological systems of the Starčevo culture, Glasnik srpskog arheološkog društva 21, Beograd, 45-70.

Omerčević, B., Šaković, E. 2010. Arheološka istraživanja na prostoru Tuzlanskog kantona, stanje, mogućnosti i perspektive, u: Baština sjeveroistočne Bosne, 1, Zavod za zaštitu i korištenje kulturno historijskog i prirodnog nasljeđa Tuzlanskog kantona, 34-47.

Pandžić, I. 2014. Kulturne veze neolita Bosne i Hercegovine sa neolitom susjednih oblasti, BIHERIT, Filozofski fakultet, Banja Luka.

Parzinger, H., 1993. Studien zur Chronologie und Kulturgeschichte der Jungstein-, Kupfer- und Fruhbronzezeit zwischen Karpaten und Mittlerem Taurus, Romisch-Germanische Forschungen Band 52, Mainz am Rhein, Teil 1

Perić, S. Butmirska kultura, Arheološtki insitut, Posebna izdanja, knjiga 29, Beograd.

Perić, S. 1985/86. Novi nalazi s Okolišta kod Visokog, GZM sv. XL/XLI, Sarajevo 15 - 22. 
Perić, S. 1995. Butmirska kultura, Arheološtki insitut u Beogradu, Posebna izdanja, knjiga 29, Beograd.

Perić, S. 2012. Stratigrafija neolitskih kultura u Bosni i Hercegovini, Posebna izdanja, NAUČNI SKUPOVI, knjiga 6, tom 2, Nauka i identitet, Pale, 21-30.

Polić. A, 1939. Pećina Hrustovača kod Sanskog mosta, GZM, LI, sv. II, Sarajevo, 1-7.

Puš, I. 1957. Neolitsko naselje u Tuzli (Slučajan nalaz u Rudarskoj ulici), ČGT, I, Tuzla, 85-102.

Rosenstock, E., 2005. Höyük, Toumba and Mogila: a settlement form in Anatolia and the Balkans and its ecological determination 6500 - 5500 BC», u: Lichter, C. (ur.) How Did Farming Reach Europe? Anatolian-European relations from the 2nd half of the 7th through the irst half of the 6th millennium BC, Istanbul, Proceedings of the International Workshop Istanbul, 20 - 22 May 2004, Veröffentlichungendes deutschen Archäologischen Instituts, BYZAS 2, 221-237.

Schier W. 1995. Vinča-Studien: Tradition und Innovation im Spatneolithikum des zentralen Balkanraumes am Beispiel der Gefaskeramik aus Vinča-Belo Brdo. Unpublished Habilitation thesis. Heidelberg University. Heidelberg.

Soklić, I., 1982. Stratigrafija i starost sononosnih naslaga grada Tuzle, Radovi Akademije nauka i umjetnosti BiH VII, Sarajevo.

Soklić, I. 1986. Tektonsko- strukturni oblici tuzlanskog bazena i Majevice, ANU BiH kn. X, Odjeljenje tehničkih nauka, 23-55.

Šošić Klindžić, R., Hršak, T., 2014. Starčevačka kultura, u: Darovi zemlje, Neolitik između Save, Drave i Dunava, Balen, J., Hršak, T., Šošić Klindžić, R. (ur.), Arheološki muzej u Zagrebu; Muzej Slavonije Osijek; Filozofski fakultet Sveučilišta u Zagrebu, 14-29.

Tasić, N. 2000a. Salt use in the Early and Middle Neolithic of the Balkan Peninsula, u: (ur) L. Nikolova, Technology, Style and Society. Contribution to the innovations between the Alps and the Black Sea in prehistory, Oxford British Arhchaeological Reports, International Series, Oxford, 35 40.

Tasić, N. 2000b.The Neolithic settlement patterns and salt, u: R.M. Geertman, B.V. Elsevier, Proceedings of the 8th World Salt Symposium, vol. 2. Amsterdam, 1139-1144.

Tasić, N. 2007. Neolit u senci- još jedan osvrt na starčevačka naselja u Bosni, ANU BiH kn. XXXVI, CBI XXXIV, Sarajevo, 5-17. 
Tasić, N. 2008. Vinča-Praistorijska metropola, Narodni muzej u Beogradu, Beograd.

Tasić, N. 2012. New evidence on salt use in the Neolithic of Southeast Europe, u: Salt and Gold: The Role of Salt in Prehistoric Europe, Provadia, Veliko Tarnovo, 213-219.

Tasić,N., Marić, M. Filipović, D., Penezić, K., Dunbar, E., Reimer, P., Barclay, A., Bayliss, A., Gaydarska, B., Whittle, A., 2016. Interwoven strands for refining the chronology of the Neolithic tell of Vinča-Belo Brdo, Serbia, Biological and Environmental Sciences Journal Articles, vol. LVIII, University of Arizona, 795-831.

Tasić N., Marić M., Bronk Ramsey C., Kromer B., Barclay A., Bayliss A., Beavan N., Gaydarska B. and Whittle A. 2016a. Vinča-Belo Brdo, Serbia: the times of a tell. Germania 93, 1-76.

Tasić N., Marić M., Filipović D., Penezić K., Dunbar E., Reimer P., Barclay A., Bayliss A., Gaydarska B. and Whittle A. 2016b. Interwoven strands for refining the chronology of the Neolithic tell of Vin $\neq$ a-Belo Brdo, Serbia. Radiocarbon 58/4, published online: 30 August 2016. Doi: 10.1017/ RDC.2016.56.

Težak-Gregl, T. 1997. Studien zur Chronologie und Kulturgeschichte der Jungstein-, Kupfer- und Fruhbronzezeit zwischen Karpaten und Mittlerem Taurus.

Težak-Gregl, T., 2014. Uvod, u: Darovi zemlje, Neolitik između Save, Drave i Dunava, Balen, J., Hršak, T., Šošić Klindžić, R. (ur.), Arheološki muzej u Zagrebu; Muzej Slavonije Osijek; Filozofski fakultet Sveučilišta u Zagrebu, 6-14.

Truhelka, Ć. 1906. Prethodno izvješće o neolitskom naselju u Donjem Klakaru, GZM, XVIII, sv. IV, Sarajevo, 449-462.

Vander Linden, M., Pandžić, I. i Orton, D. 2014. New radiocarbon dates for the Neolithic period in Bosnia \& Herzegovina, ANU BiH, CBI, XXXXIII, Sarajevo, 7-35

Vrabac, S., Ferhatbegović, Z., Đulović, I., Bijedić, Dž. 2010. Nalazak morskih fosila u sonoj fromaciji ležišta kamene soli Tetima kod Tuzle, u: Zbornik radova III kongresa geologa BiH, Sarajevo.

Vrabac, S. 1991. O nalasku marinskih fosila u sonoj formaciji tuzlanskog bazena sa osvrtom na starost i genezu ležišta kamene soli, Rudarsko-geološki fakultet, Geološki anali balkanskog poluostrva, Tuzla. 
Vrabac, S., Ćorić, S. 2008. Revizija „,karpata“ tuzlanskog bazena sa osvrtom na stratigrafski položaj sone formacije, Geološki glasnik 37, Sarajevo, 71- 81.

Whittle, A., Bartosiewicz, L., Borić, D., Pettitt, P., Richards, M., 2002. In the beginning: New Radiocarbon Dates for the Early Neolithic in Northern Serbia and South-East Hungary, Anateus 25,Budapest, 63-117.

Whittle, A., Bayliss, A., Barclay A., Gaydarska, B., Banffy, E., Borić, D., Drasovean, F., Jakucs, J., Marić, M., Orton, D., Pantović, I., Schier, W., Tasić, N., Vander Linden, M. 2016. A Vinča potscape: formal chronological models for the use and development of Vinča ceramics in south-east Europe, Documenta Praehistorica XLIII, Ljubljana, 1-60. 
PRILOG 1. Dokumentacija arheološkog odjeljenja Muzeja Istočne Bosne u Tuzli

PRILOG 2. Izvještaj o rezultatima zaštitnog arheološkog istraživanja na lokalitetu Trg Slobode (dokumentacija sa terenskog istraživanja)

PRILOG 3. Službeni glasnik BiH, br. 32/03

PRILOG 4. Kulturno-istorijsko i prirodno nasljeđe opšine Zvornik (Elaborat), br. 77/91, Tuzla, 1991.

PRILOG 5. Kulturno-istorijsko i prirodno nasljeđe opštine Lopare (Elaborat), Tuzla, 1990.

PRILOG 6. Dokumentacija sa iskopavanja Gornje Tuzle (1955.-1958.), Zemaljski muzej u Sarajevu.

PRILOG 7. Izvještaj sa arheološkog iskopavanja na lokalitetu neolitskog naselja u Gornjoj Tuzli 14.07.-19.07.2008. godine (04-155/08), 22.07.2008. godine, Muzej Istočne Bosne u Tuzli

PRILOG 8. Izvještaj sa arheološkog iskopavanja na lokalitetu neolitskog naselja u Gornjoj Tuzli 2009. godine, Muzej Istočne Bosne u Tuzli

PRILOG 9. Dnevnik sa arheološkog istraživanja na lokalitetu neolitskog naselja Gornja Tuzla 14.07-19.07. 2008. godine (04-157/08), 23.07.2018. godine

PRILOG 10. Izvještaj o arheološkim iskopavanjima na prostoru Gornje Tuzle, 27.08.2018.- 31.08. 2018.

PRILOG 11. https://www.katastar.ba/pregled

PRILOG 12. Odluka o proglašenju arheološkog područja Korića han u Gračanici nacionalnim spomenikom Bosne i Hercegovine, Službeni glasnik BiH, br. 32/03

PRILOG 13. Arheološko područje - prahistorijsko naselje u Butmiru, općina Ilidža (faza 1), Sarajevo, 2015. 


\section{5d Biografija}

Dženan Brigić rođen je u Tuzli 7. marta 1991. godine. Godine 2009. upisao je studij na Odsjeku za historiju Filozofskog fakulteta u Sarajevu. Dodiplomski ciklus studija uspješno je okončao 2012. i iste je godine nastavio studij na diplomskom ciklusu te diplomirao na temu "Istočni dio Donje Panonije u protohistoriji i klasičnom periodu". Doktorski studij arheologije upisao je u akademskoj godini 2014./2015.

Sudjelovao je na nekoliko arheoloških istraživanja na prostoru Bosne i Hrvatske, u saradnji sa Filozofskim fakultetima u Sarajevu i Zagrebu, te godine 2018. pokrenuo vlastito istraživanje na lokalitetu Gornja Tuzla, u svrhu pisanja doktorskog rada.

Tokom studija sudjelovao je na nekoliko stručnih naučnih skupova u Bosni i Hercegovini, te vezano uz to objavio nekoliko radova.

Bibliografija

1. Dž. Brigić, Gornja Tuzla - prahistorijsko naselje sjeveroistočne Bosne (Kulturna stratigrafija na osnovu Čovićevog iskopavanja iz 60-ih godina 20. st.), Colloqvivm: In honorem professoris Esad Pašalić - quinquagesimo anniversario eius mortis, Acta Illyrica II, Sarajevo, 2017., 27-41.

2. Dž. Brigić, Historijat prahistorijskih arheoloških istraživanja bosanskohercegovačkog dijela Panonije, BIHERIT - Curricular reform of Heritage Sciences in Bosnia and Herzegovina (Kurikularna reforma baštinskih nauka u Bosni i Hercegovini), Sarajevo, 2014., 133-139.

3. Dž. Brigić, Kontinuitet naseljenosti Bosanske Panonije od neolita do željeznog doba, Baština Sjeveroistočne Bosne br. 6, Tuzla, 2014., 30-38.

4. Dž. Brigić, Uticaj podizanja trajnih naselja i uzgoja žitarica na razvoj putnih komunikacija, Naučna konferencija (okrugli stol) na temu: "Godine razvoja i integracije - 2000 godina namjesništva Publija Kornelija Dolabele u provinciji Dalmaciji", Acta Illyrica I, Sarajevo, 2014., 32 43.

5. Dž. Brigić, Narodi antičke Panonije (Zemlje antičkog Ilirika prije i poslije Milanskog edikta), Filozofski fakultet u Sarajevu, Sarajevo, 2013., 220-233 (elektronsko izdanje). 


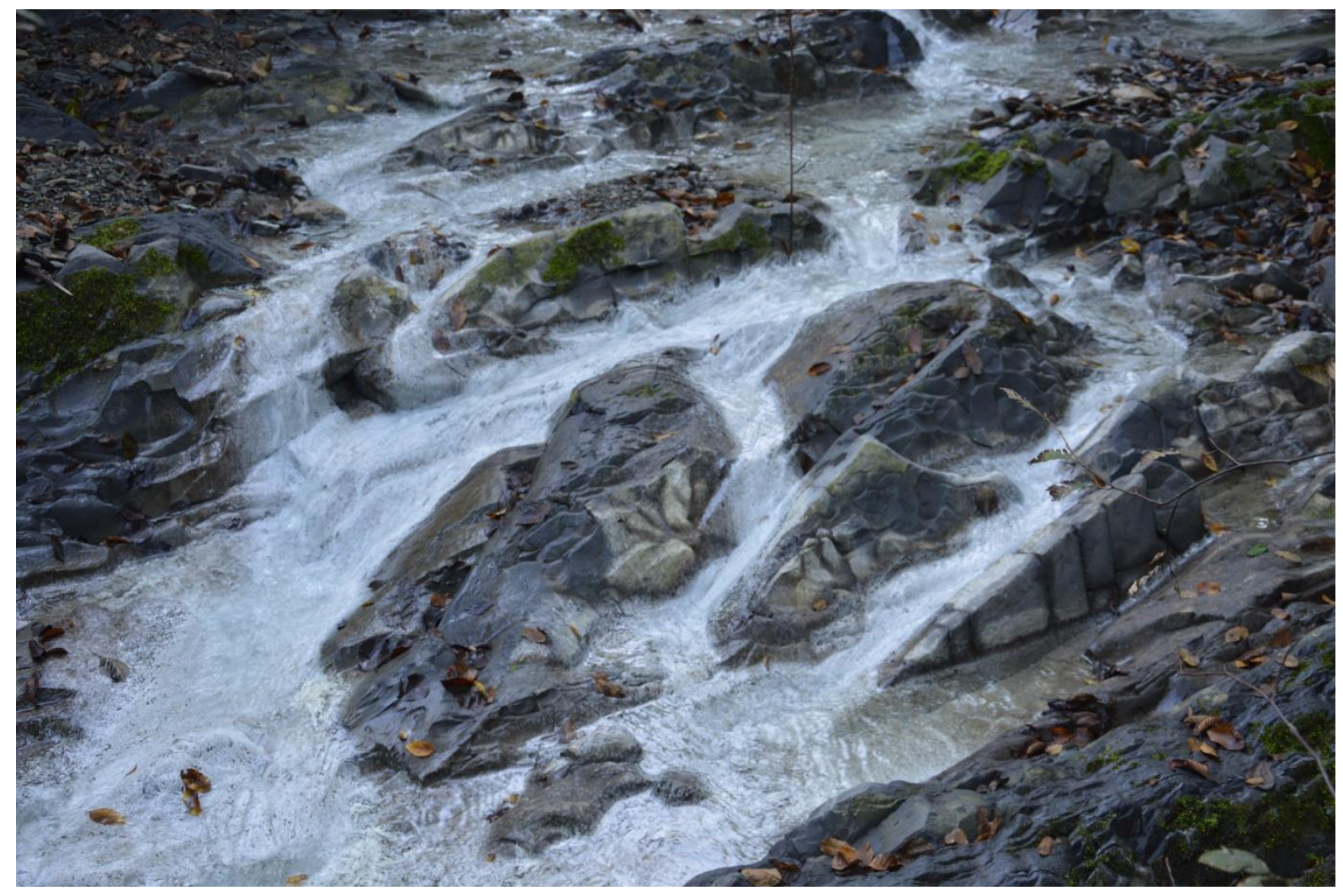

Tabla 1a. Izvor rijeke Jale (snimio Dž. Brigić)

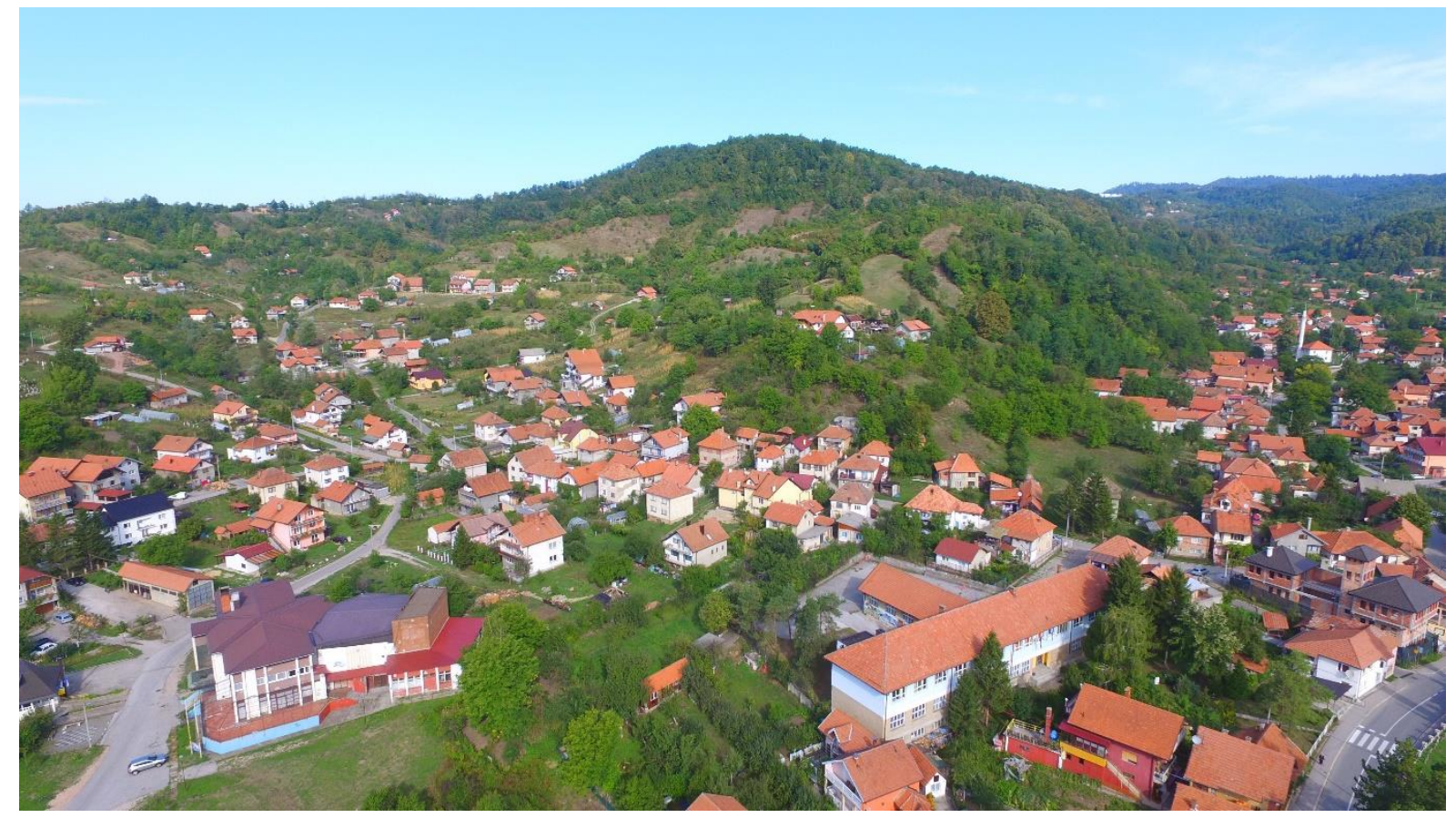

Tabla 1b. Dronski snimak Gornje Tuzle, pogled na centralni dio lokaliteta (snimio M. Burić) 

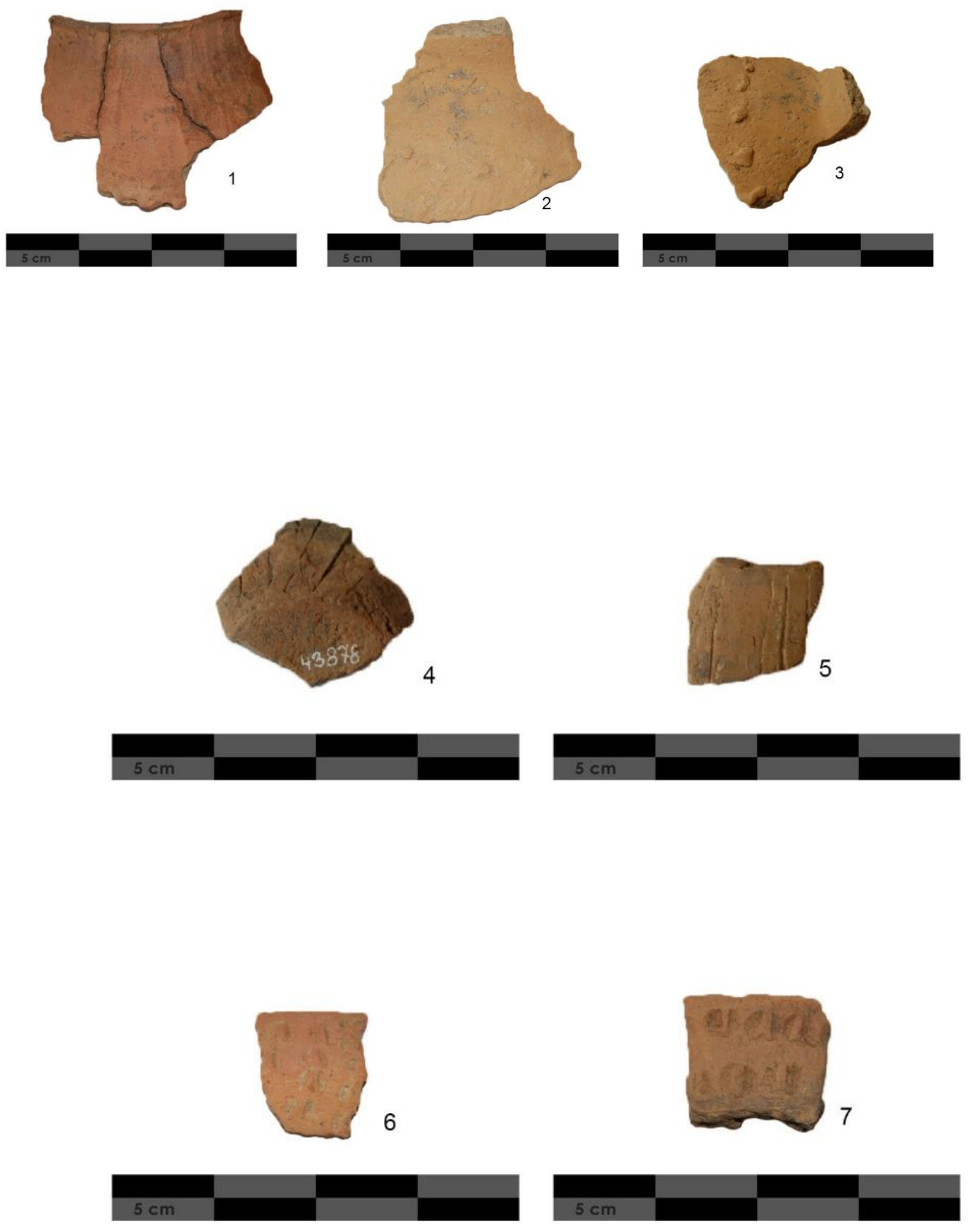

Tabla 2. Keramika iz stratuma VIb (snimio Dž. Brigić) 

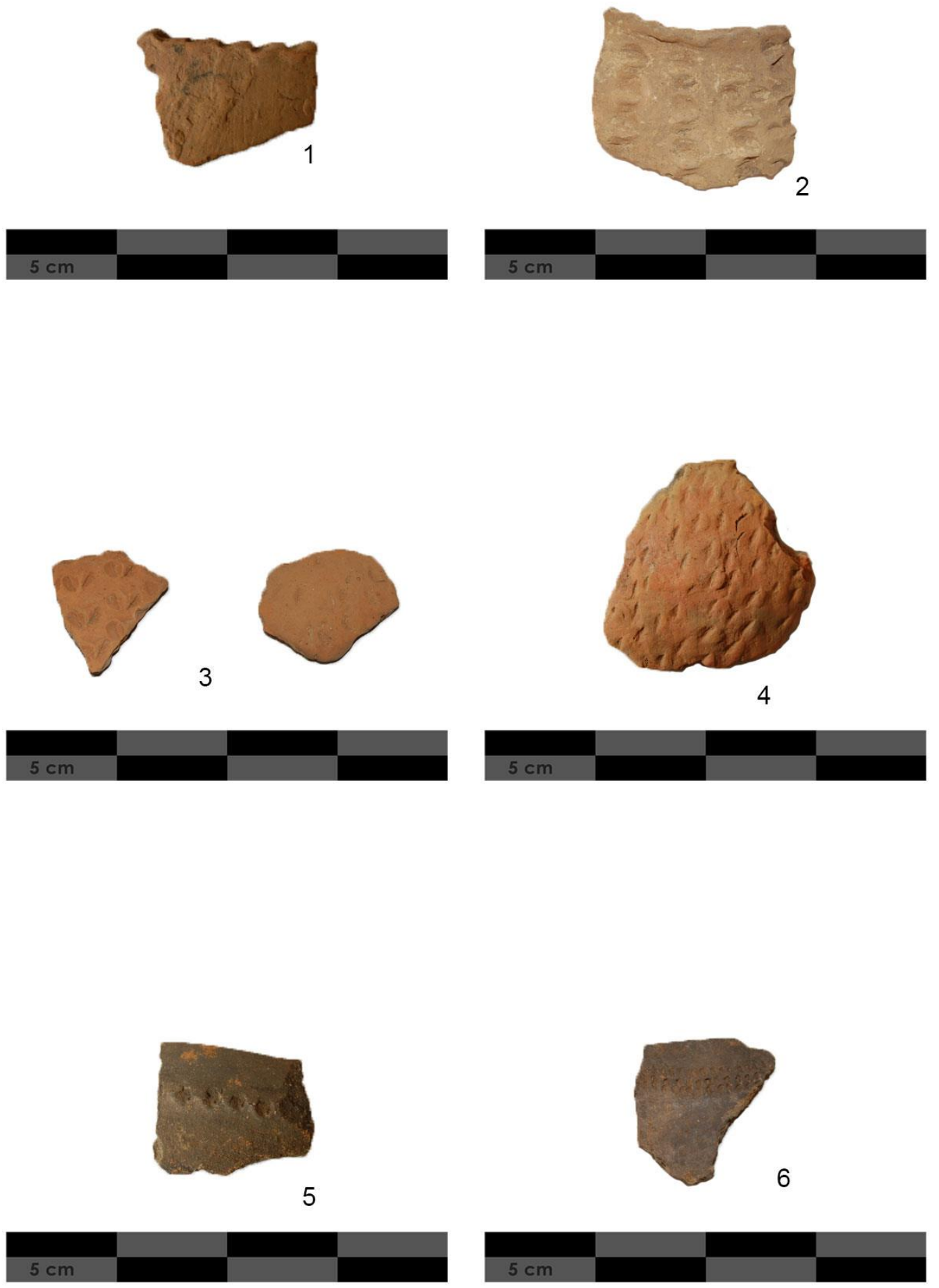

Tabla 3. Keramika iz stratuma VIb (1-3) i stratuma VIa (3-6) (snimio Dž. Brigić) 

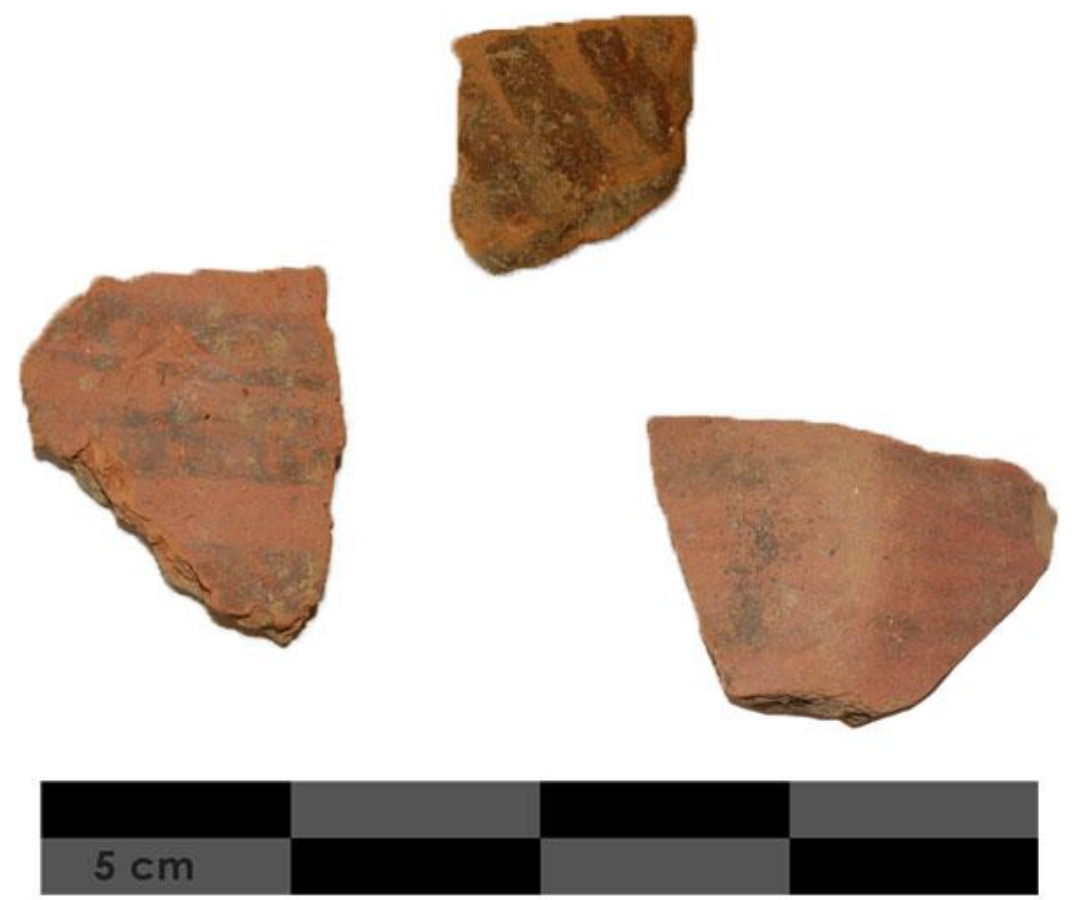

Tabla 4. Slikana keramika, stratum VIb, dubina 5,45 m (snimio Dž. Brigić)
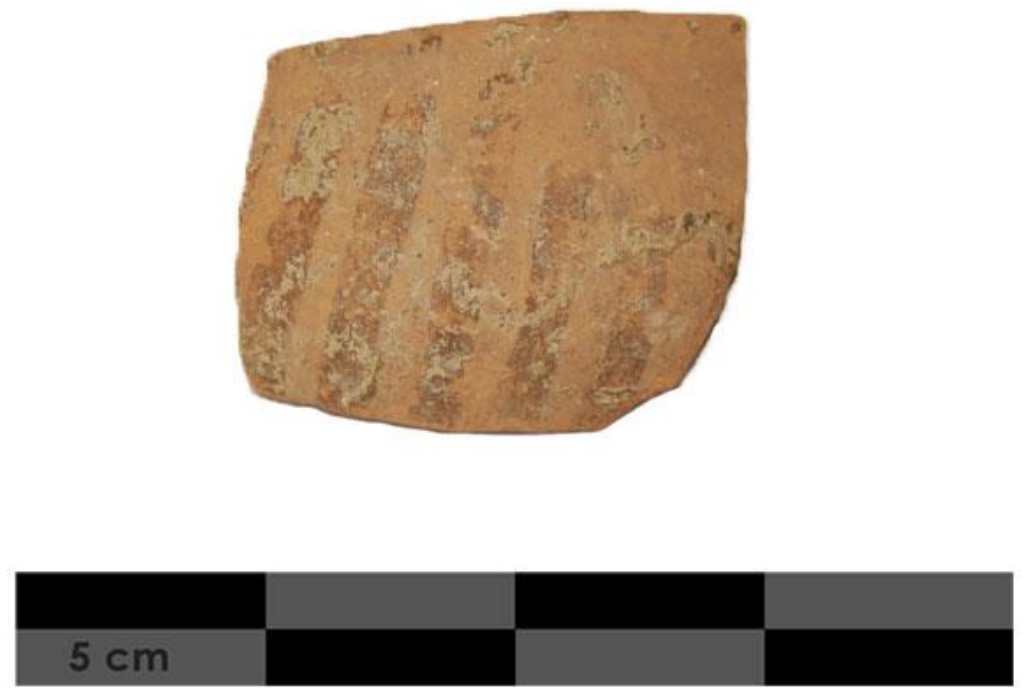

Tabla 5. Slikana keramika, stratum VIb, dubina 5,40 m (snimio Dž. Brigić) 

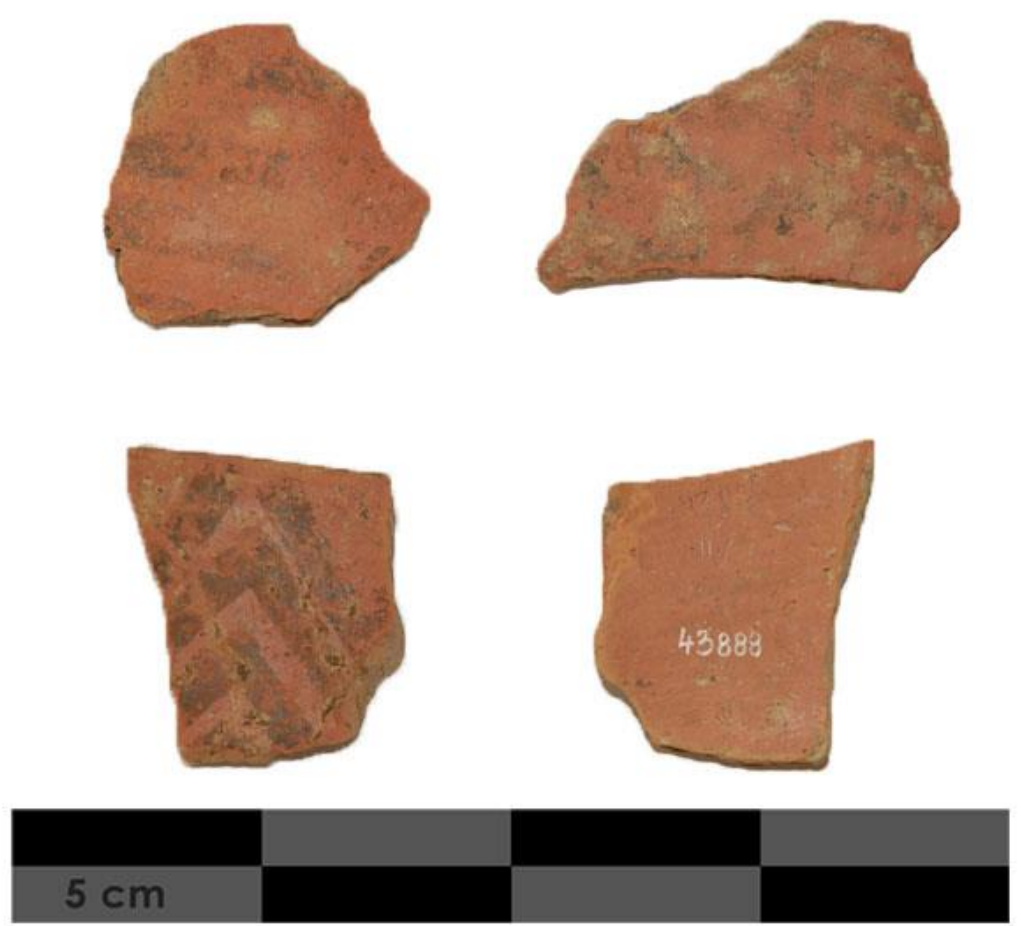

Tabla 6. Slikana keramika, stratum VIb, dubina 5,40 m (snimio Dž. Brigić)
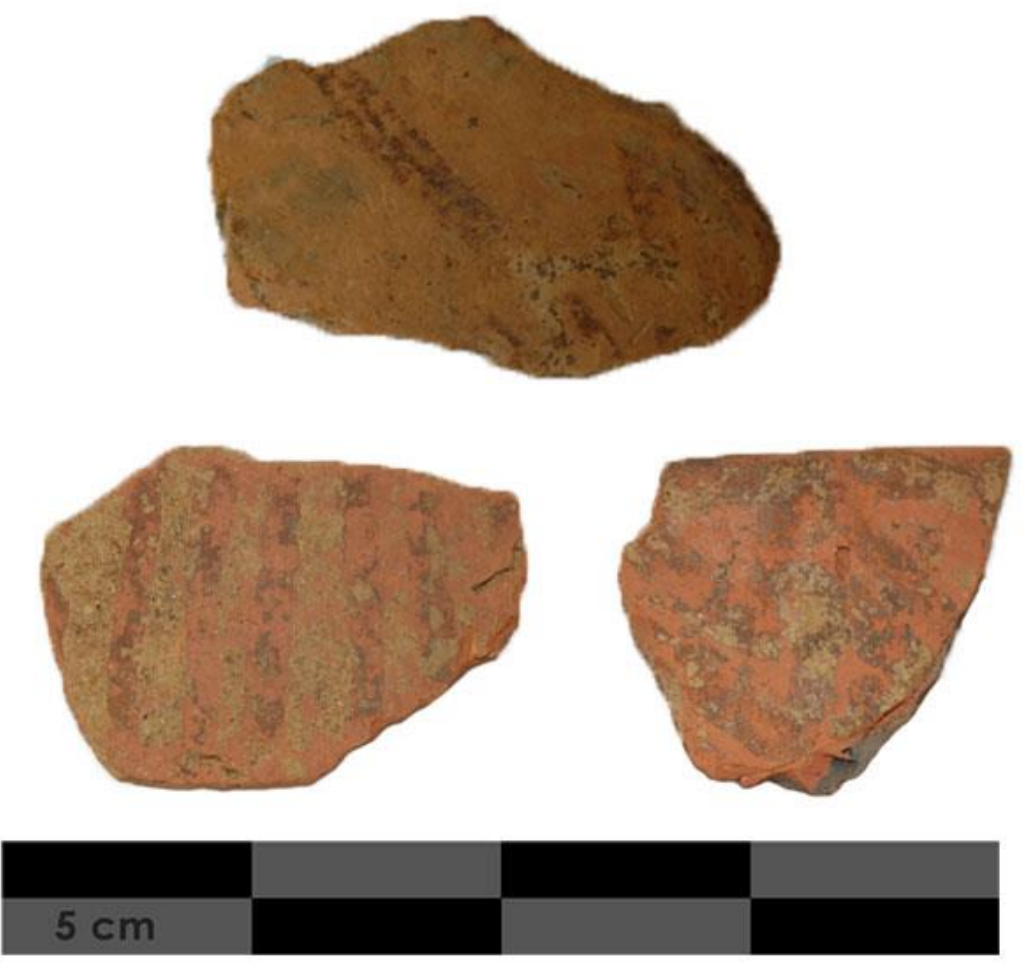

Tabla 7. Slikana keramika, stratum VIb, dubina 5,40 m (snimio Dž. Brigić) 


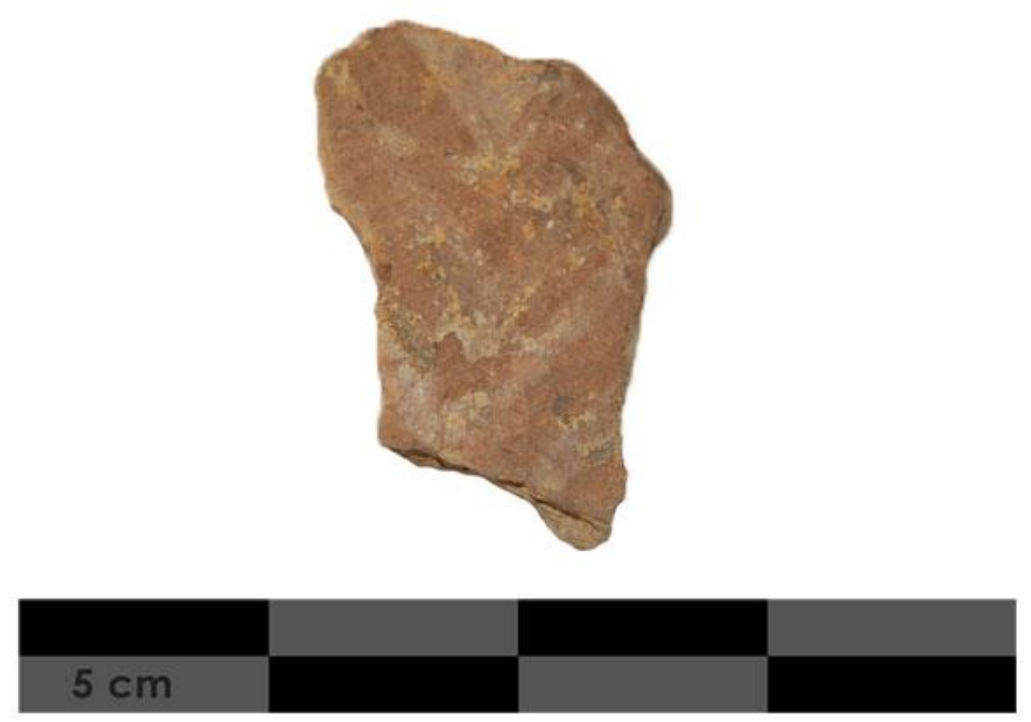

Tabla 8. Slikana keramika, stratum VIb, dubina 5,25 m (snimio Dž. Brigić)
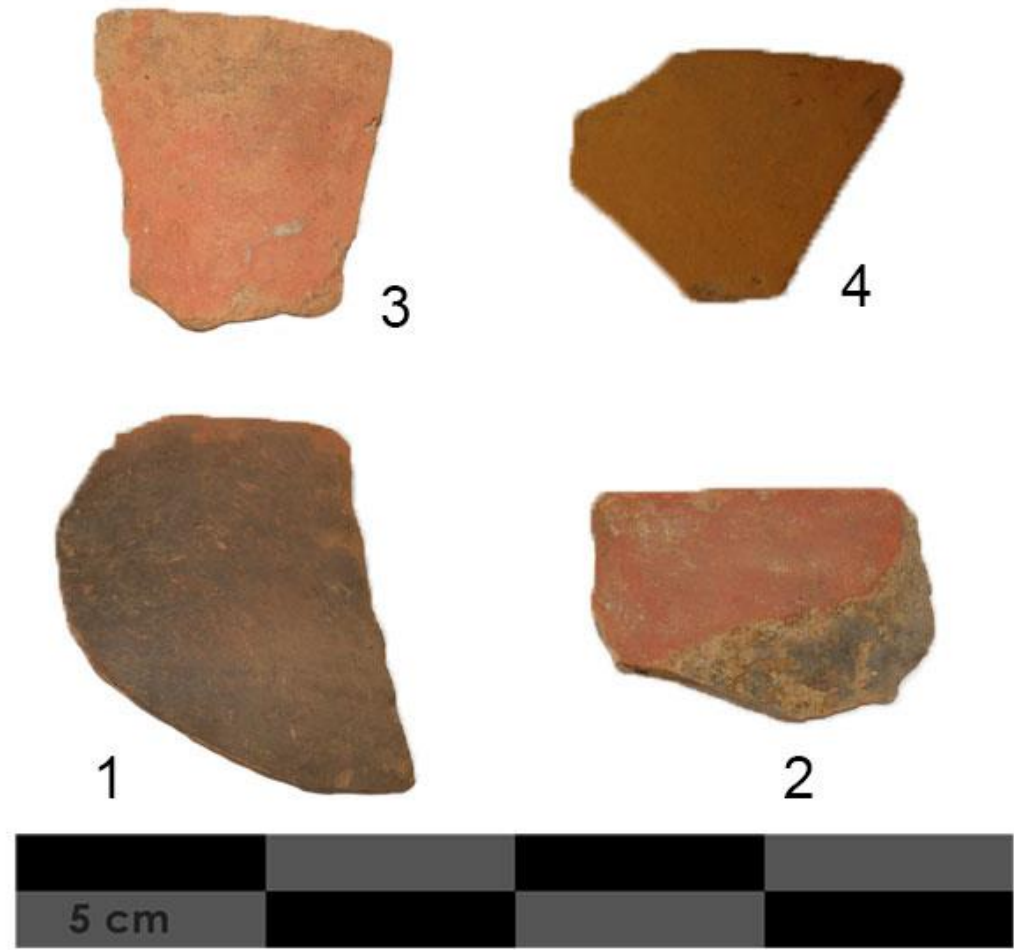

Tabla 9. Monohromna keramika, stratum VIb: 1 - 5,45 m; 2 i 3 - 5,40 m; 4-5,25 m (snimio Dž. Brigić) 

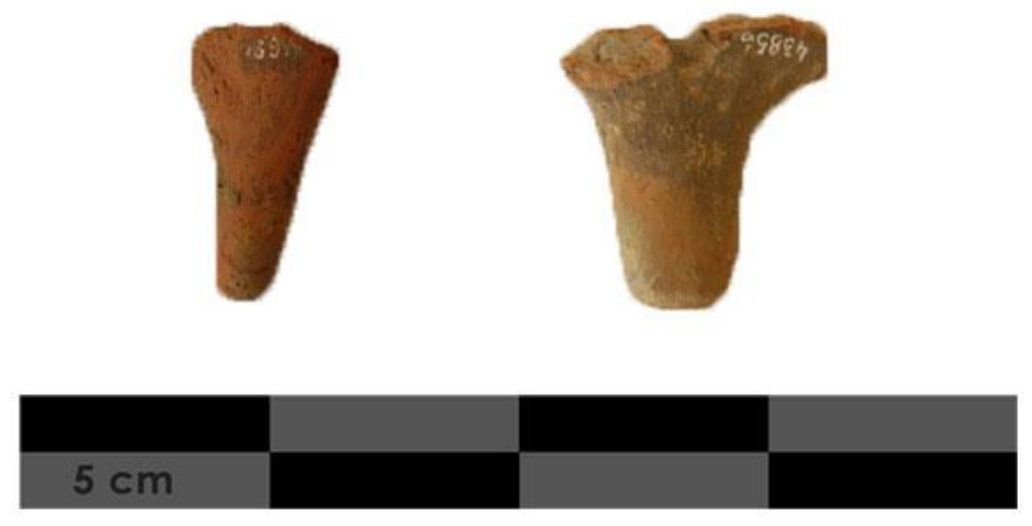

Tabla 10. Noge žrtvenika monohromne keramike, stratum VIb (snimio Dž. Brigić)
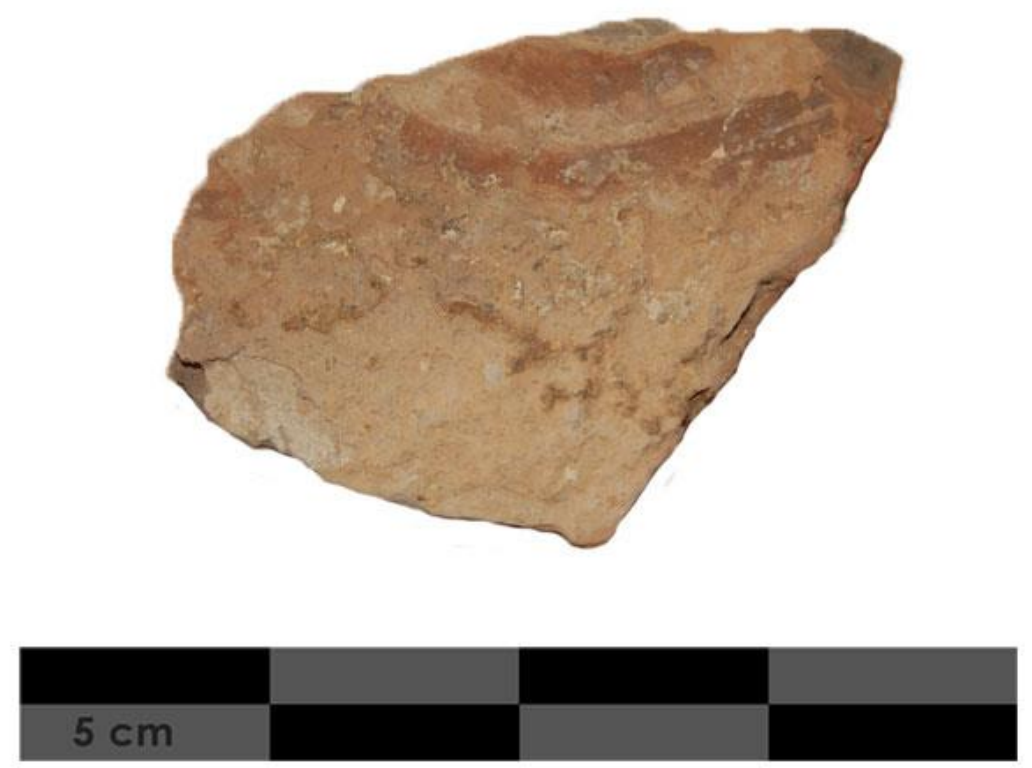

Tabla 11. Slikana keramika, stratum VIa, dubina 5,0 m (snimio Dž. Brigić) 

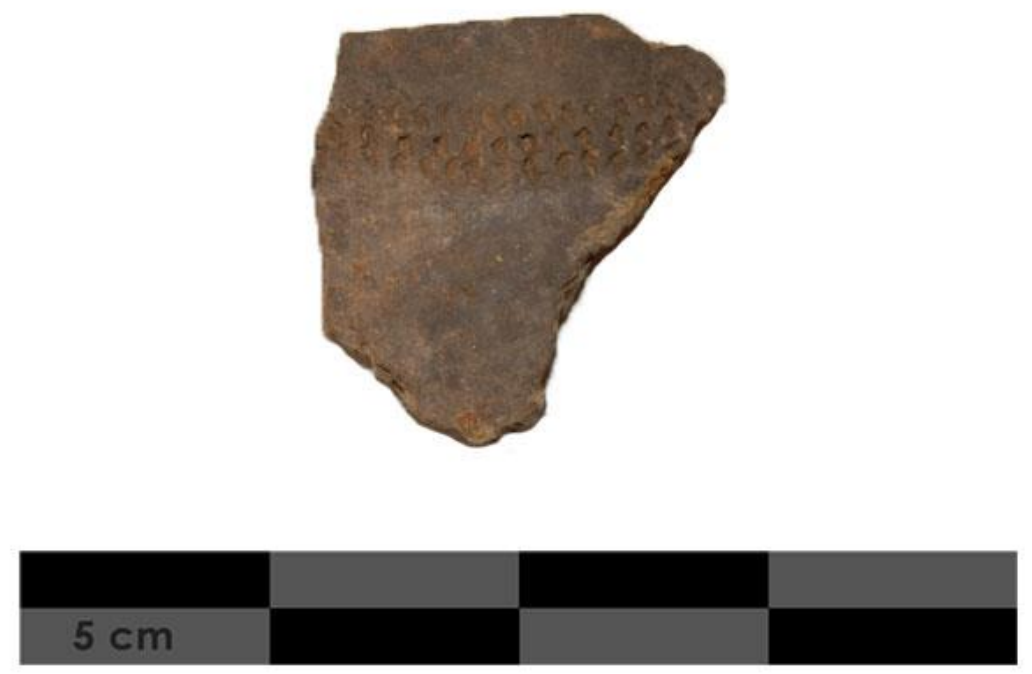

Tabla 12. Tamnocrna posuda ukrašena horizontalnim plastičnim trakama u tri reda, stratum VIa, dubina 5,0 m (snimio Dž. Brigić)
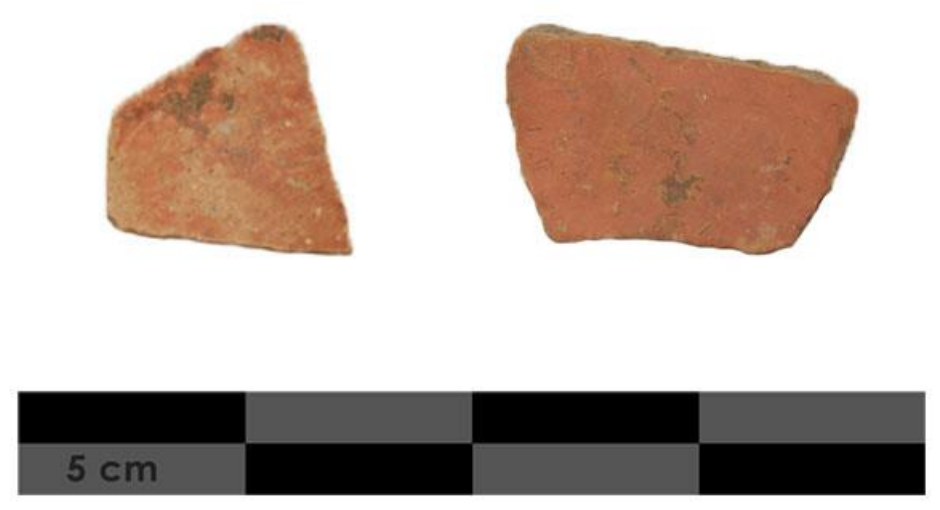

Tabla 13. Monohromna keramika čija je površina bojena u crveno, stratum VIa (snimio Dž. Brigić) 


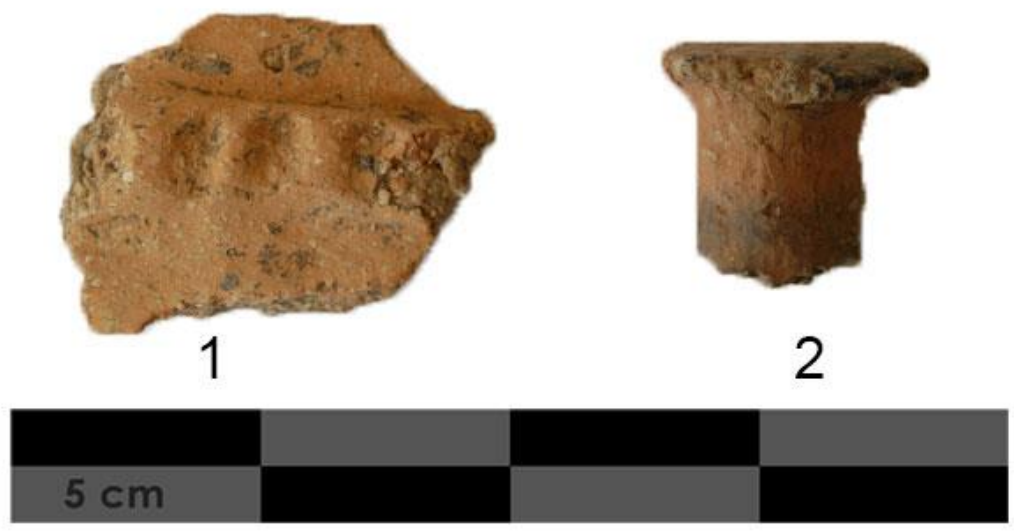

Tabla 14. Impresso fragmenat i čepasta noga, stratum $\mathrm{V}$, dubine: 1 -4,32 m; 2-4,85 m (snimio Dž. Brigić)

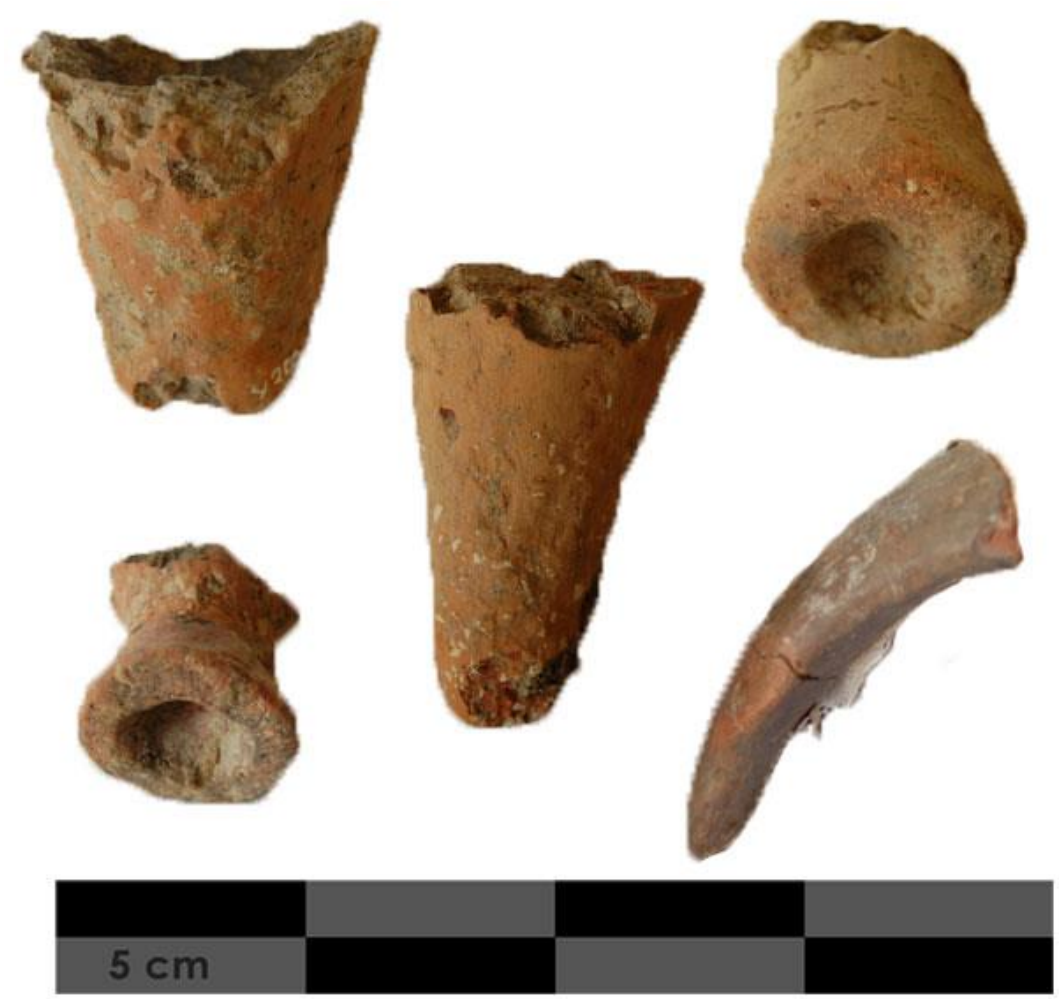

Tabla 15. Noge posude, stratum V (snimio Dž. Brigić) 

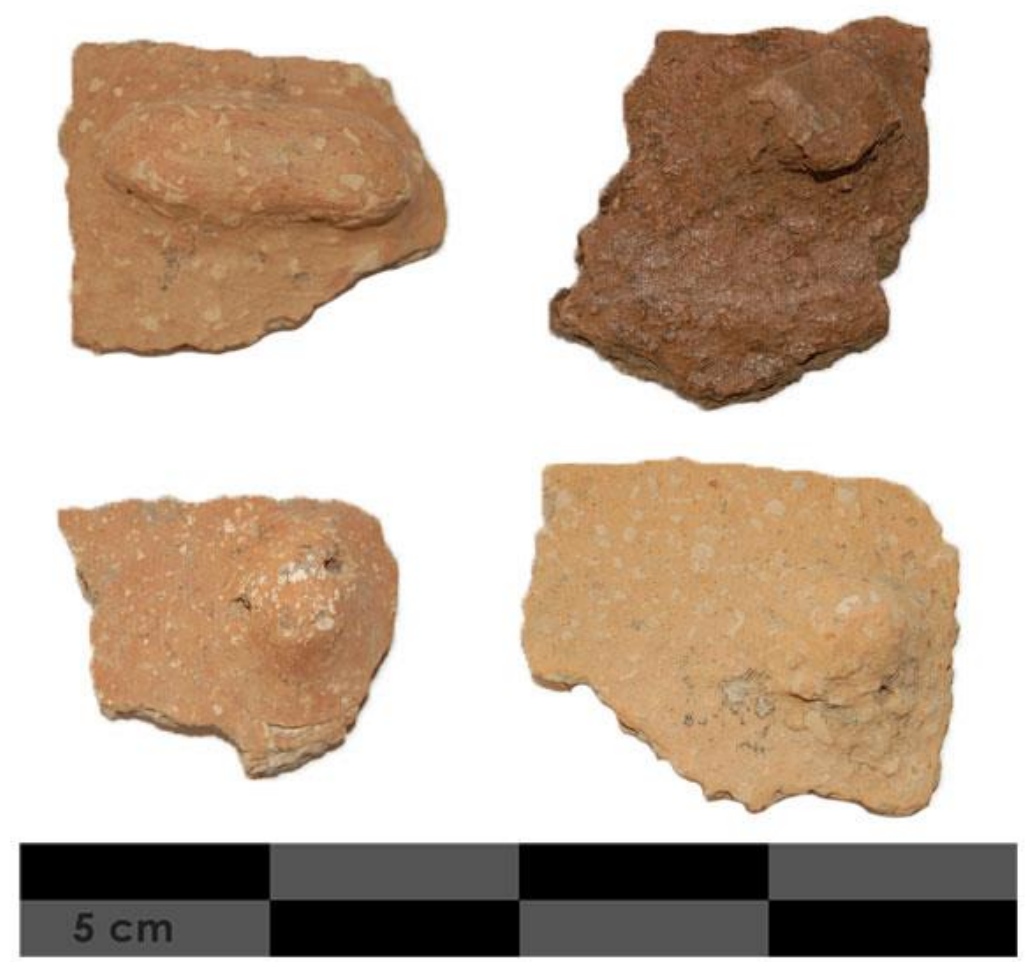

Tabla 16. Neke od karakterističnih bradavičastih drški iz stratuma V (snimio Dž. Brigić)

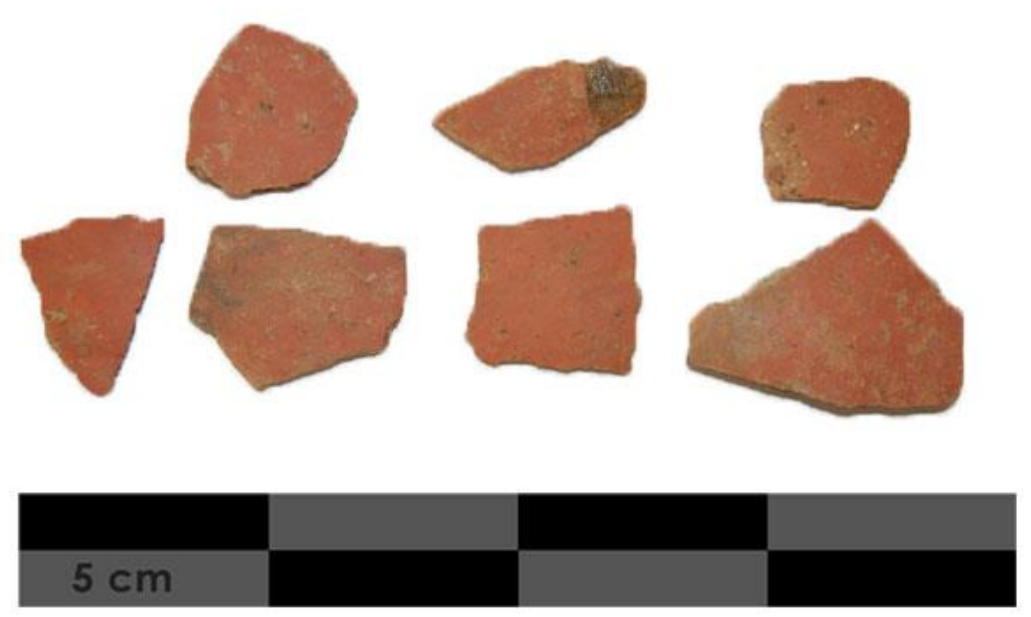

Tabla 17. Monohromna keramika, stratum V, dubina 4,85 m (snimio Dž. Brigić) 

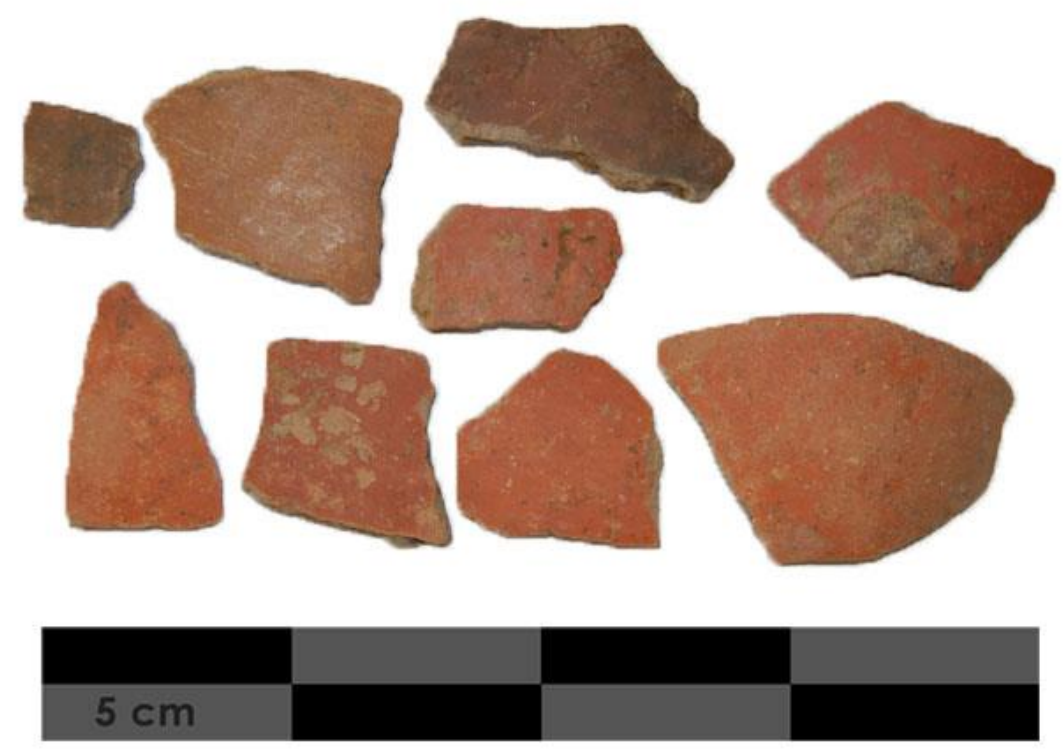

Tabla 18. Monohromna keramika, stratum V, dubina 4,76 m (snimio Dž. Brigić)

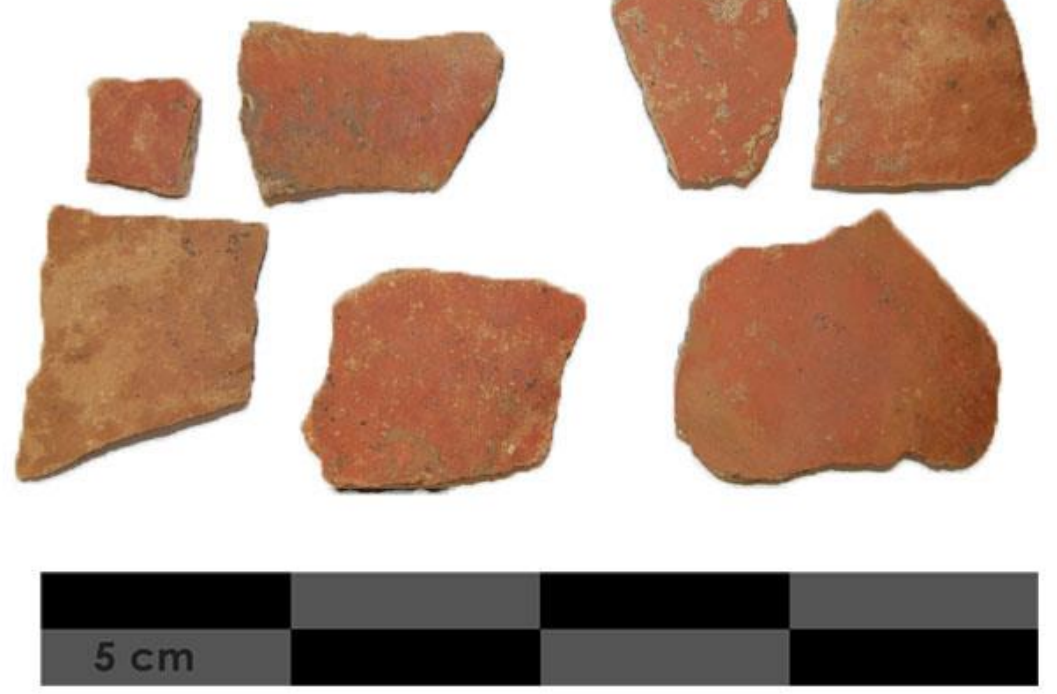

Tabla 19. Monohromna keramika, stratum V, dubina 4,62 m (snimio Dž. Brigić) 

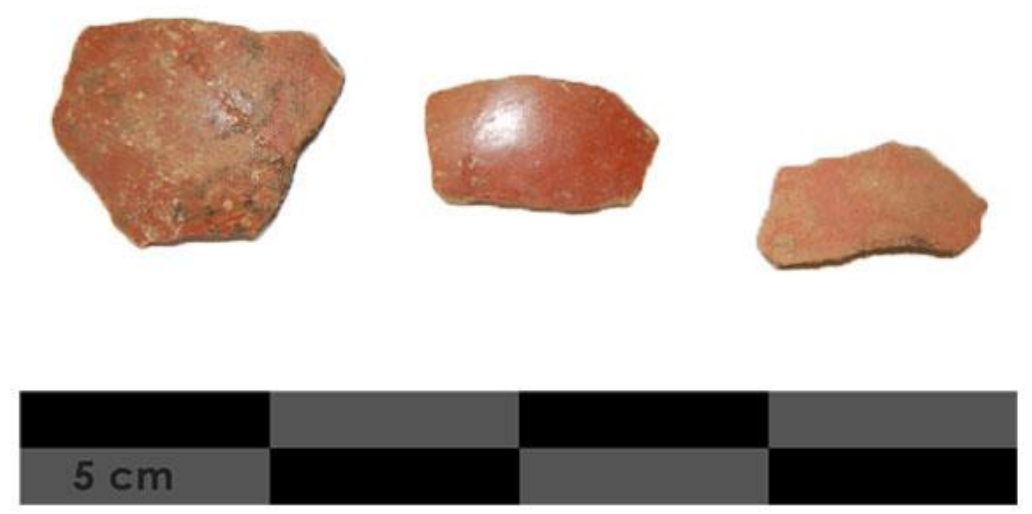

Tabla 20. Monohromna keramika, stratum V, dubina 4,48 m (snimio Dž. Brigić)

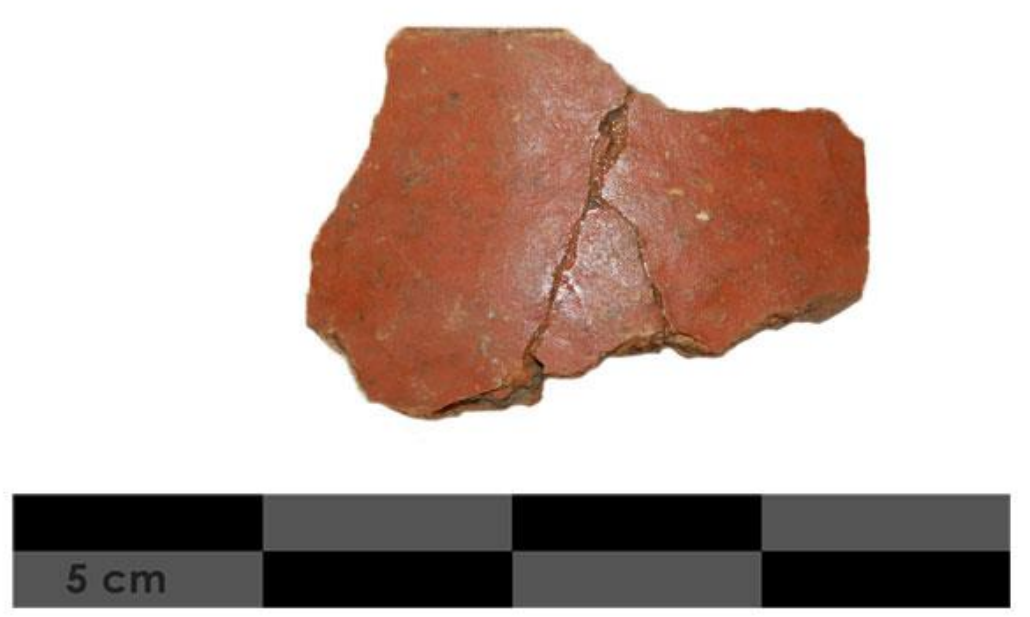

Tabla 21. Obod monohromne poluloptaste crveno bojene posude, stratum V, dubina 4,76 m (snimio Dž. Brigić) 

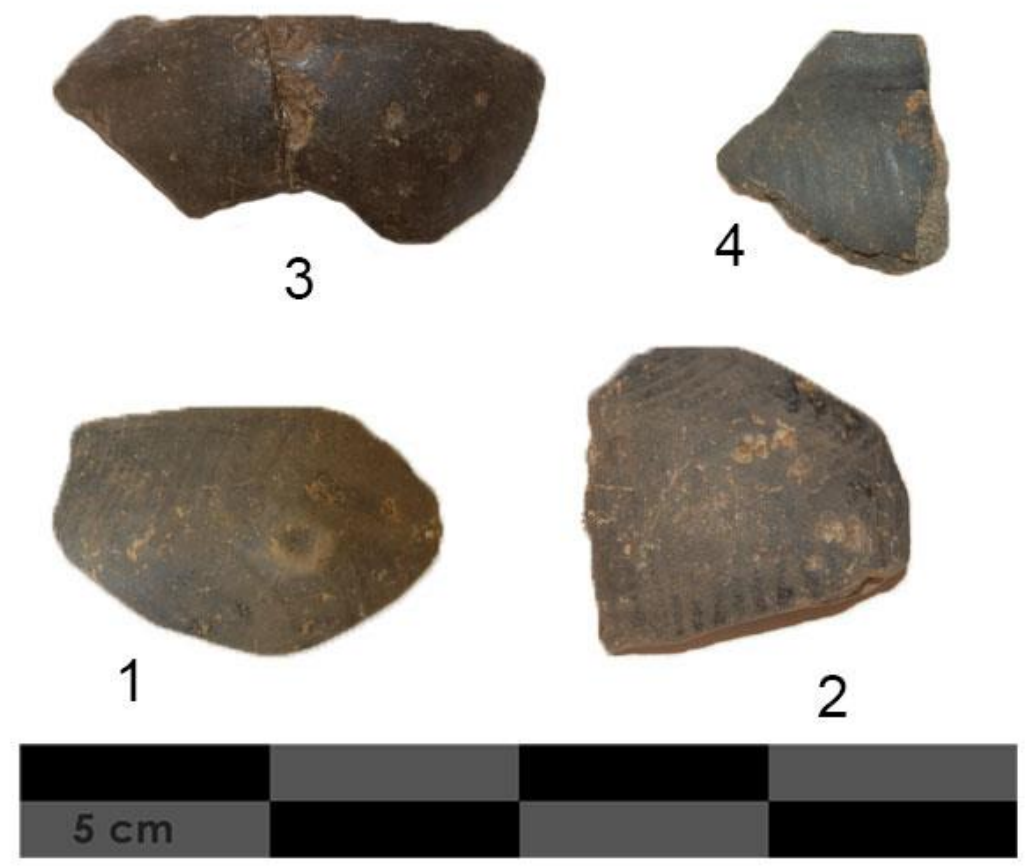

Tabla 22. Crnoglačana keramika, stratum V: 1 i $2-4,76$ m; 3 i $4-4,62$ m (snimio Dž. Brigić)
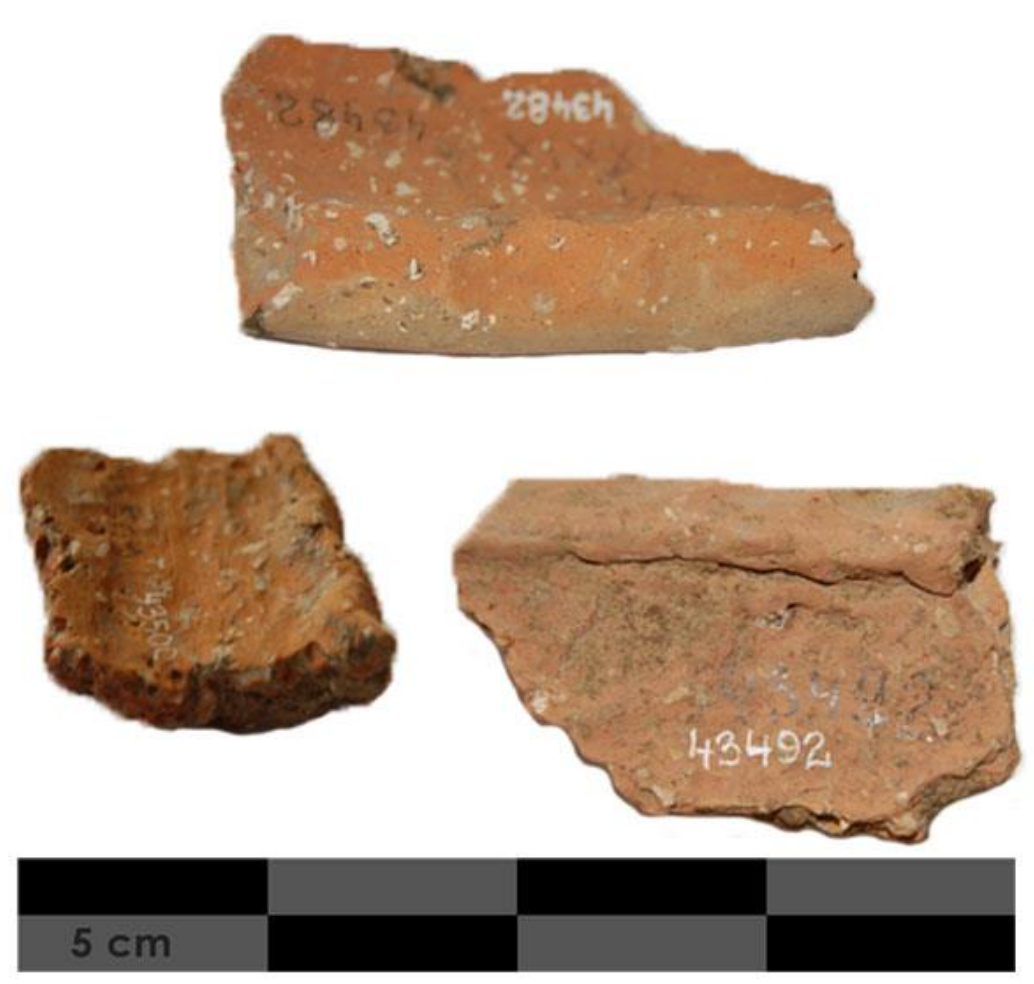

Tabla 23. Keramika iz stratuma IV (snimio Dž. Brigić) 

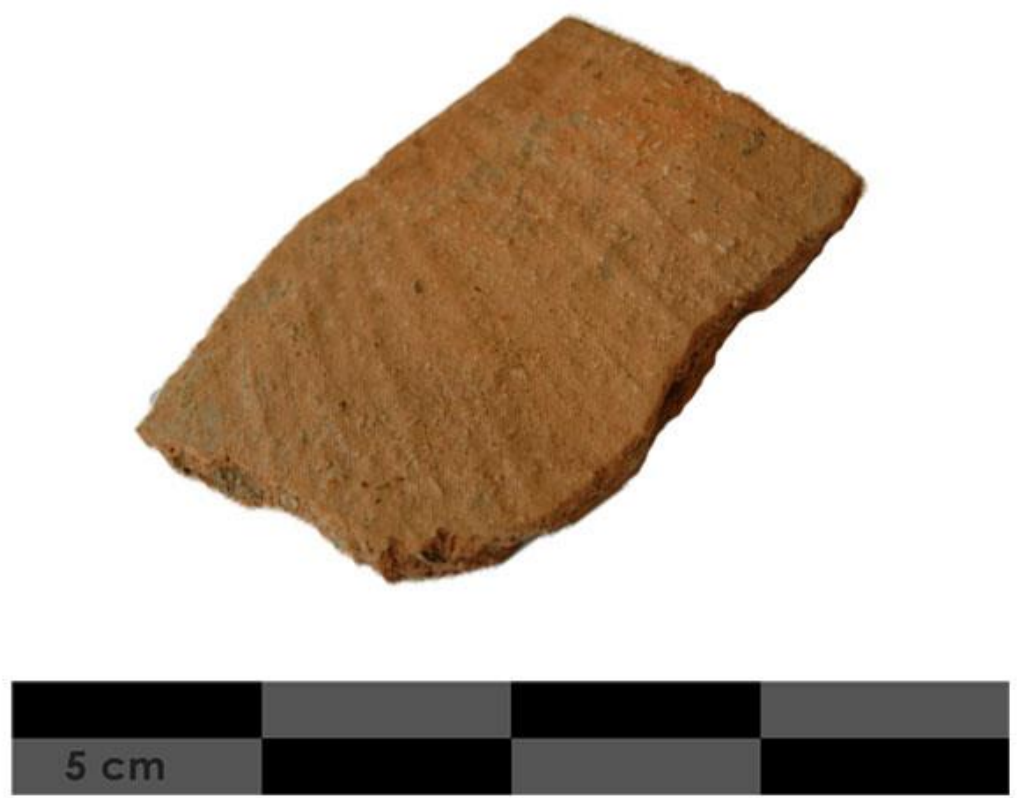

Tabla 24. Posuda sa ravnim obodom, stratum IV (snimio Dž. Brigić)

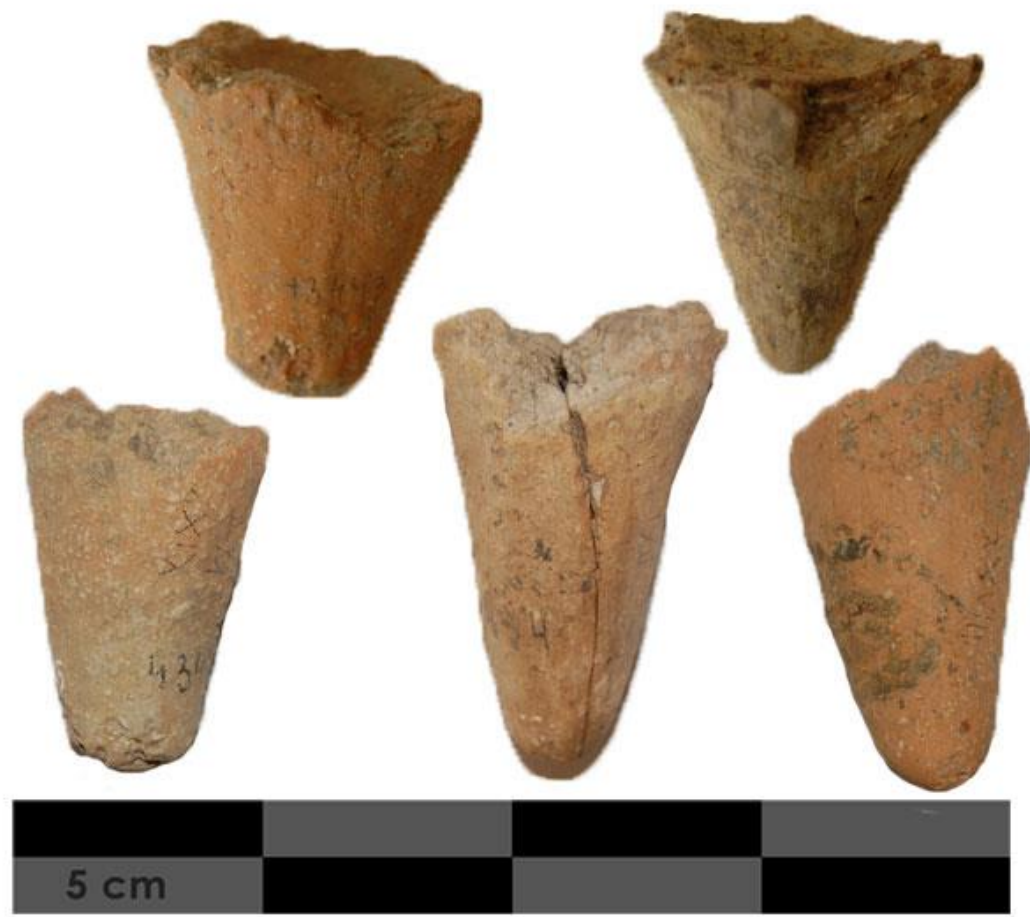

Tabla 25. Konične prema dole sužene noge, stratum IV (snimio Dž. Brigić) 


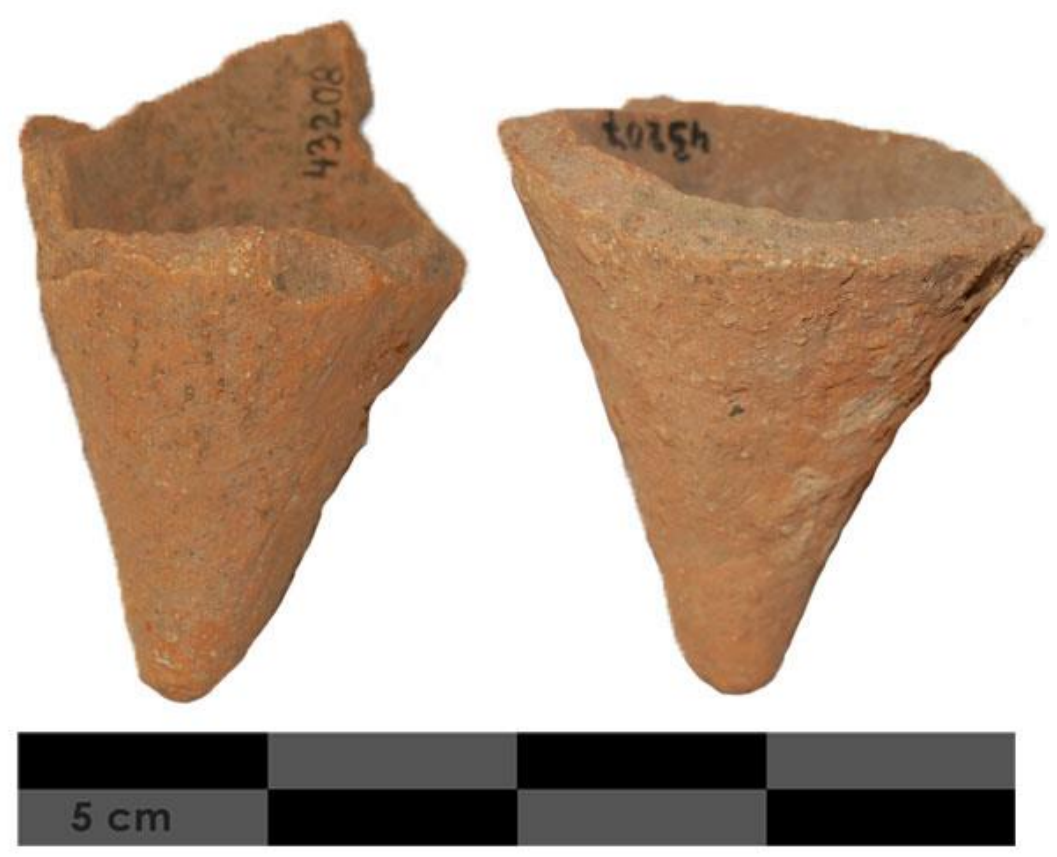

Tabla 26. Posude sa šiljatim dnom, stratum III (snimio Dž. Brigić)

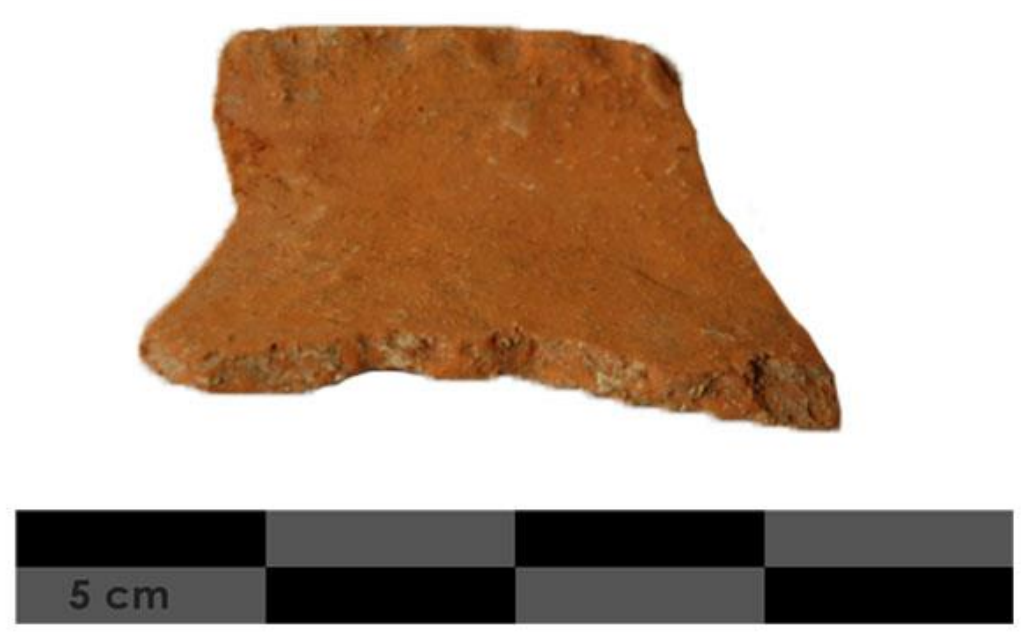

Tabla 27. Trbušasta posuda sa izvraćenim obodom ukrašena utiskivanjem prstiju, stratum III (snimio Dž. Brigić) 


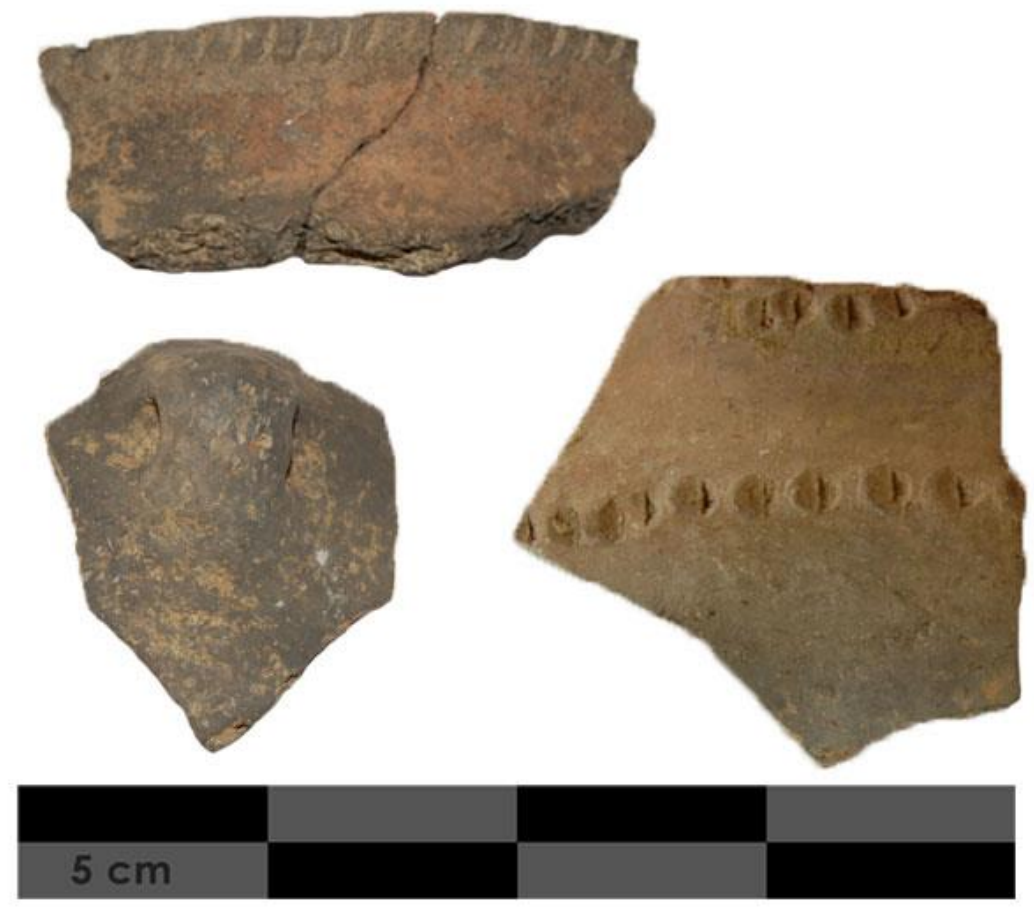

Tabla 28. Gruba sivocrna keramika, stratum III (snimio Dž. Brigić)

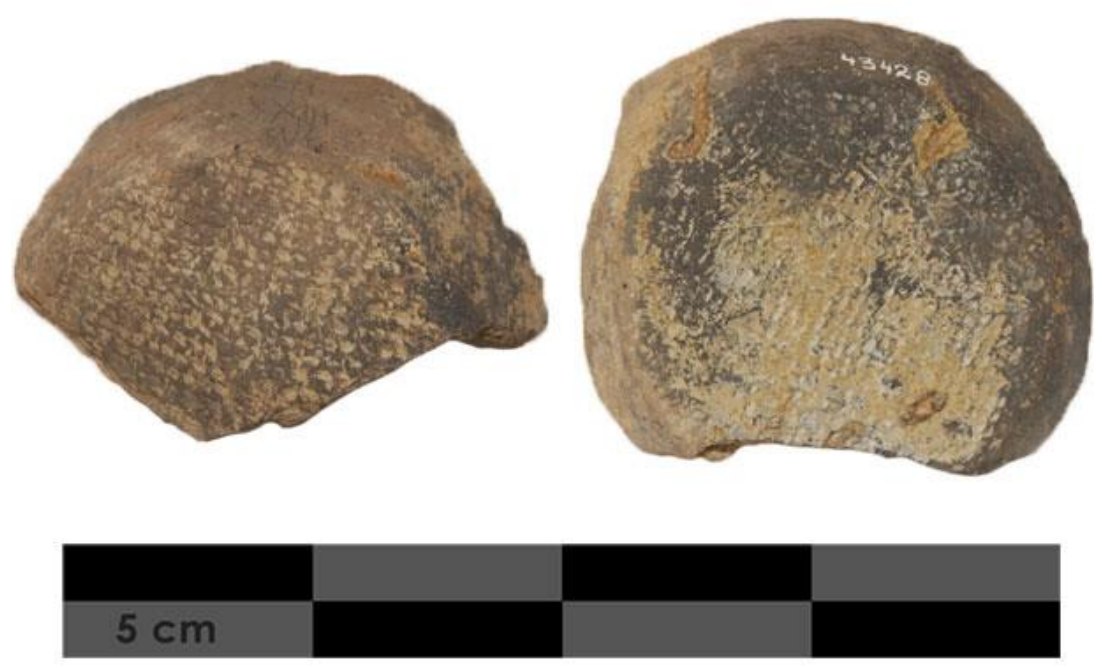

Tabla 29. Dno posuda sa otiskom asure, stratum III (snimio Dž. Brigić) 


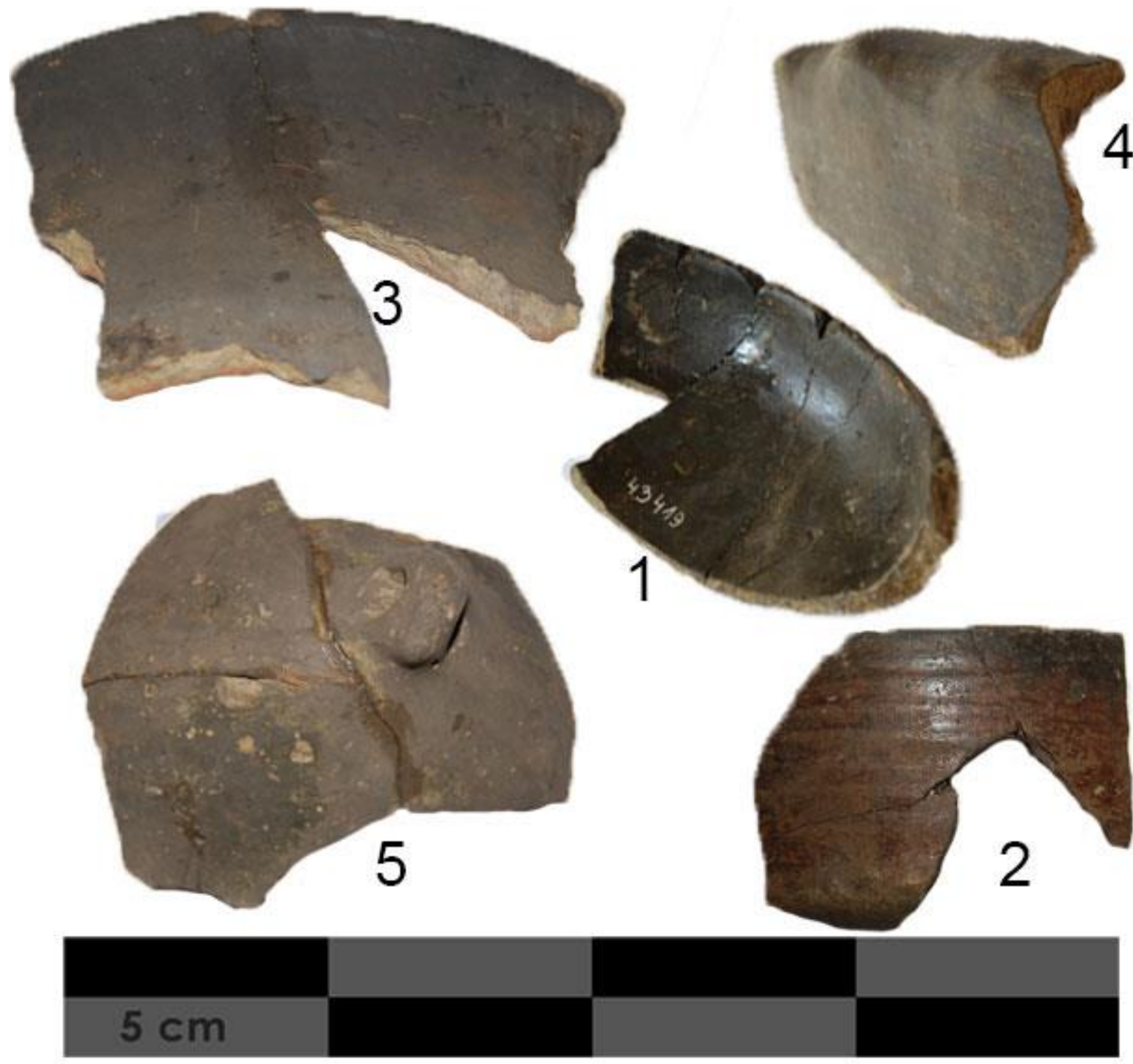

Tabla 30. Osnovni oblici fine keramike iz stratuma III: 1 - manja zdjela sa uvučenim obodom; 2 - zdjele sa cilindričnim vratom i ojačanim ramenom; 3 - zdjela sa ojačanim ramenom i široko izvijenim vratom; 4 - duboke zdjele sa prema gore suženim vratom, sa ispupčenjima na centralnom dijelu; 5 - amfore sa malim ušicama kao drškama (snimio Dž. Brigić) 

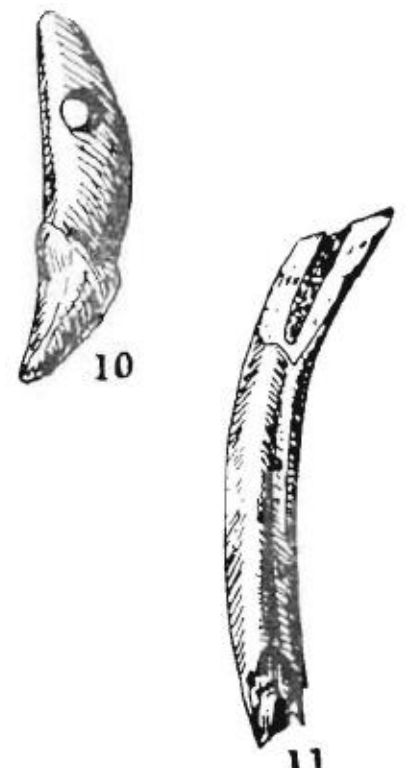

11
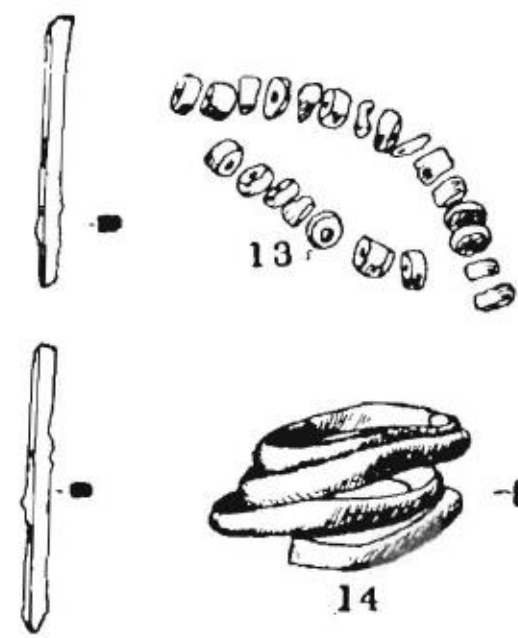

12

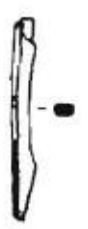

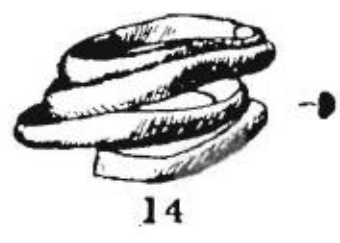

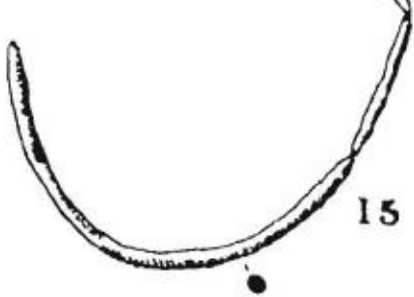

Tabla 31. Nakit od bakra, stratum III (Čović 1960-61: 98)

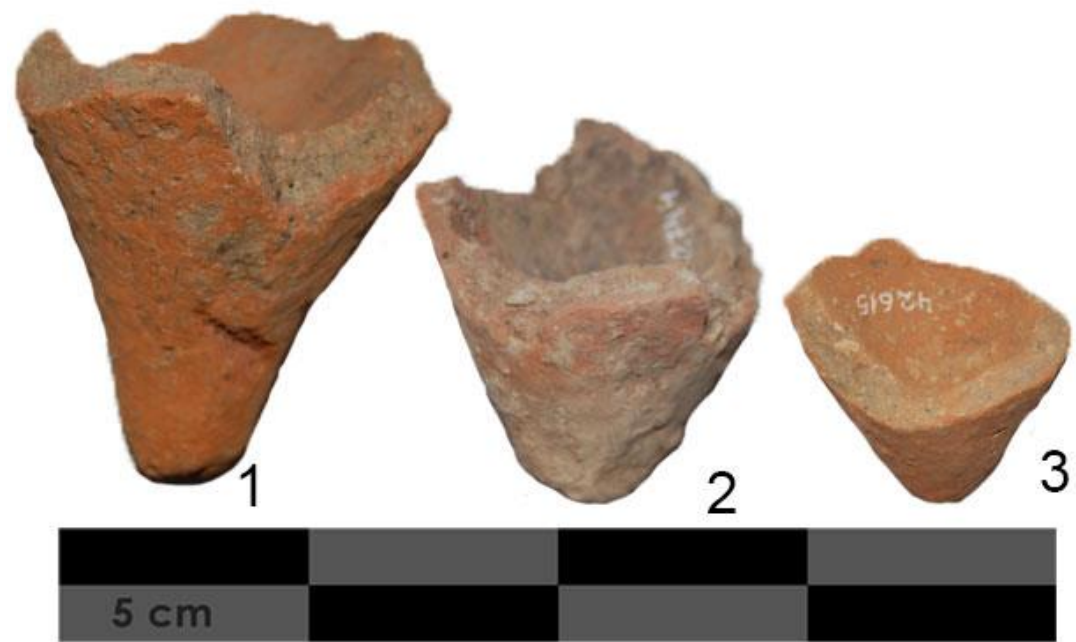

Tabla 32. Posude sa zdepastim dnom, stratum II: 1 - dubina 2,0 m; 2 - dubina 1,78 m; 3 dubina $1,54 \mathrm{~m}$ (snimio Dž. Brigić) 

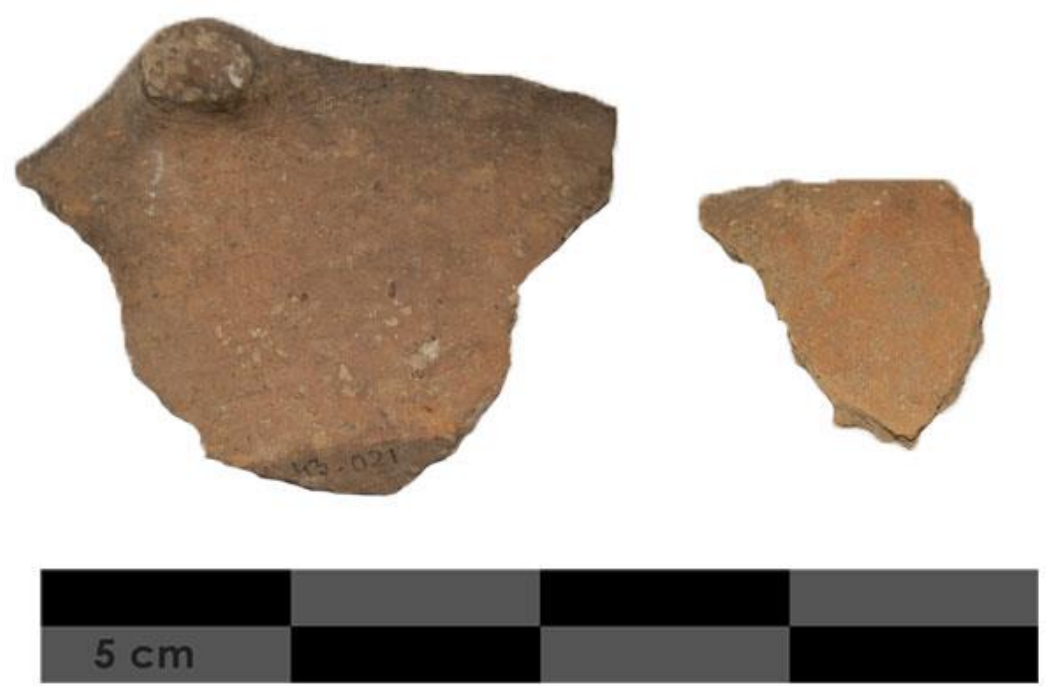

Tabla 33. Posude sa bradavičastim drškama na obodu, stratum II (snimio Dž. Brigić)

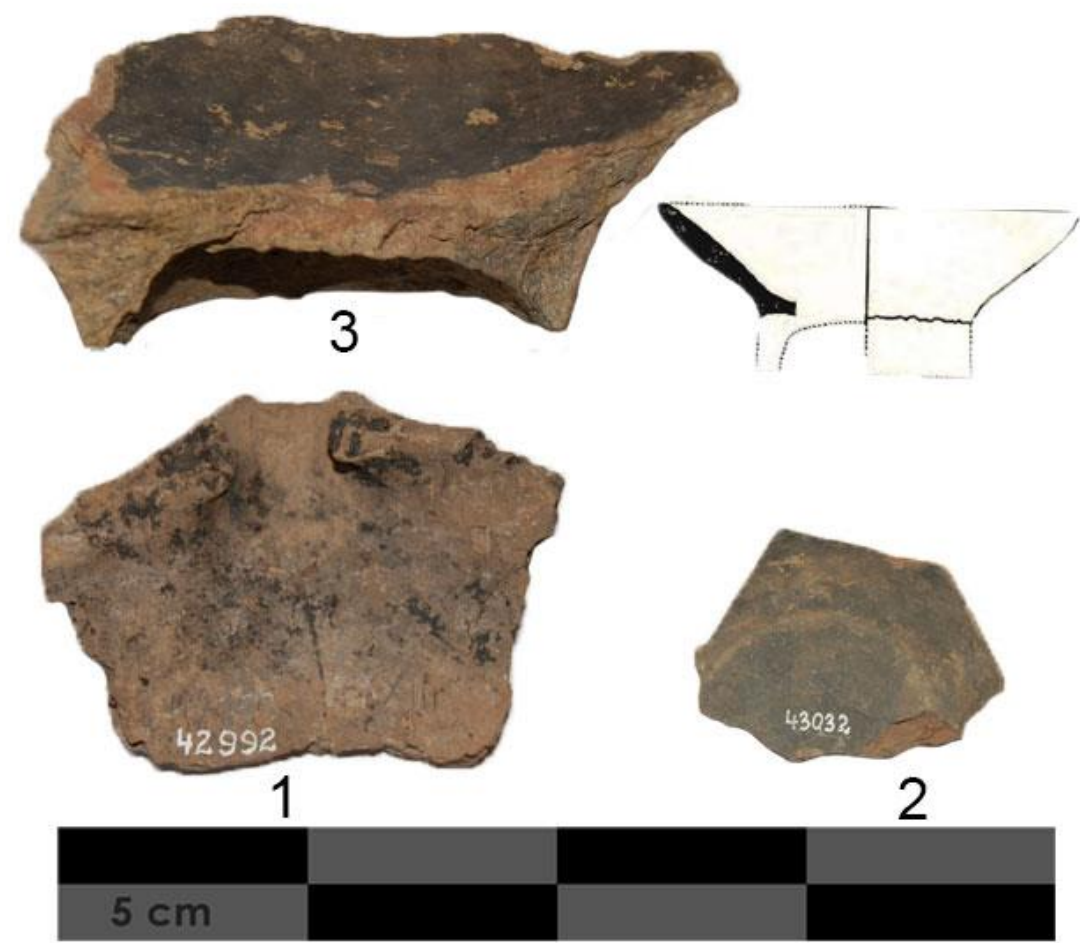

Tabla 34. Novi oblici grube keramike, stratum II: 1 - zdjele sa kljunom; 2 - plitke posudice; 3 - posude na veoma širokoj cilindričnoj nozi (snimio Dž. Brigić) 


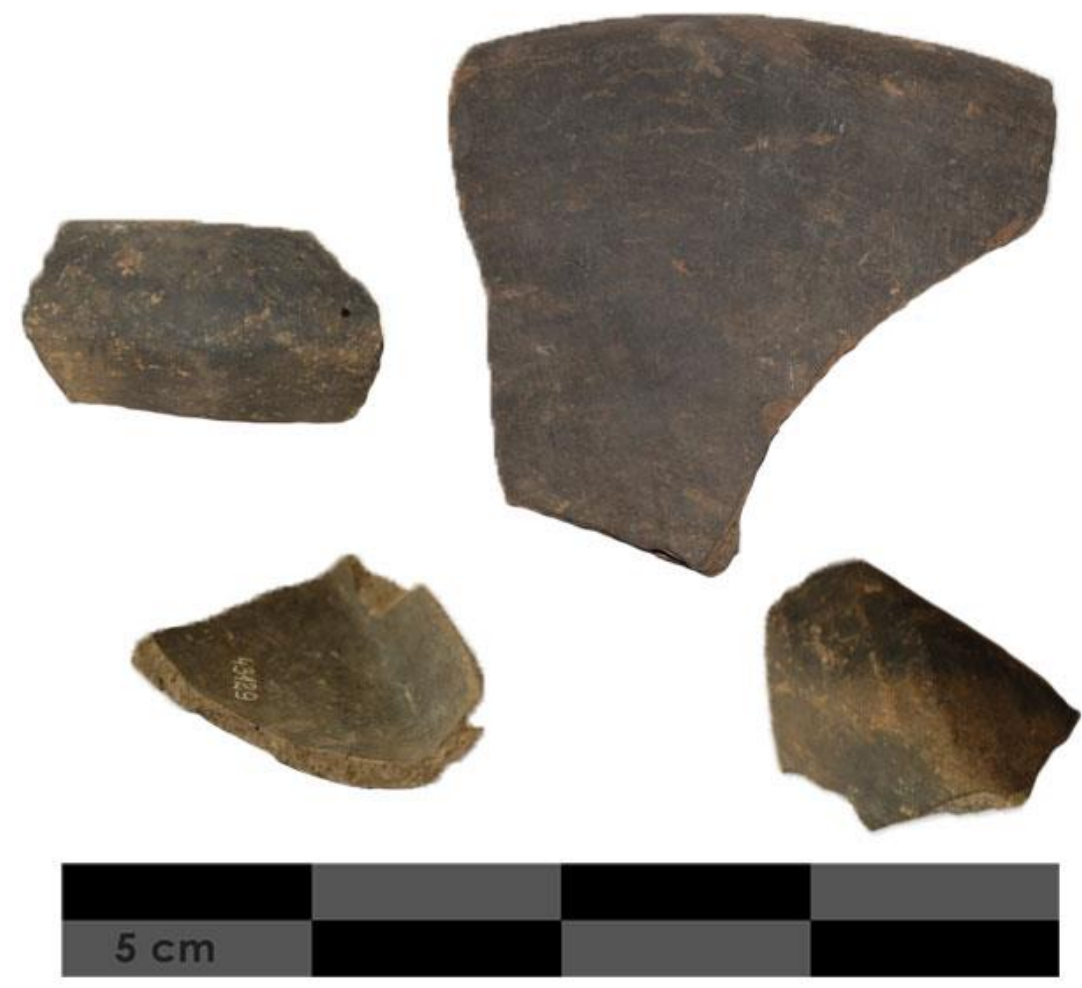

Tabla 35. Zdjele sa uvučenim obodom, stratum II (snimio Dž. Brigić)

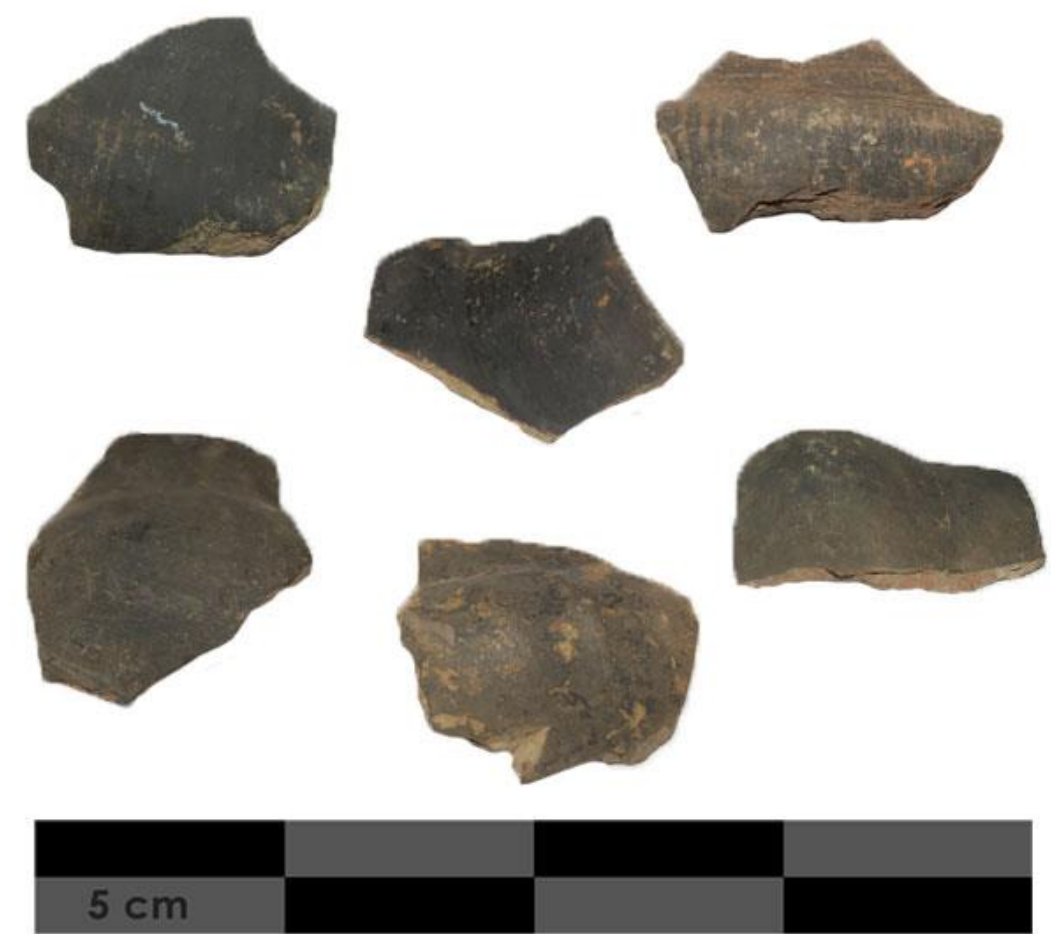

Tabla 36. Zaobljene poluloptaste zdjele sa kratkim širokim vratom, stratum II (snimio Dž. Brigić) 


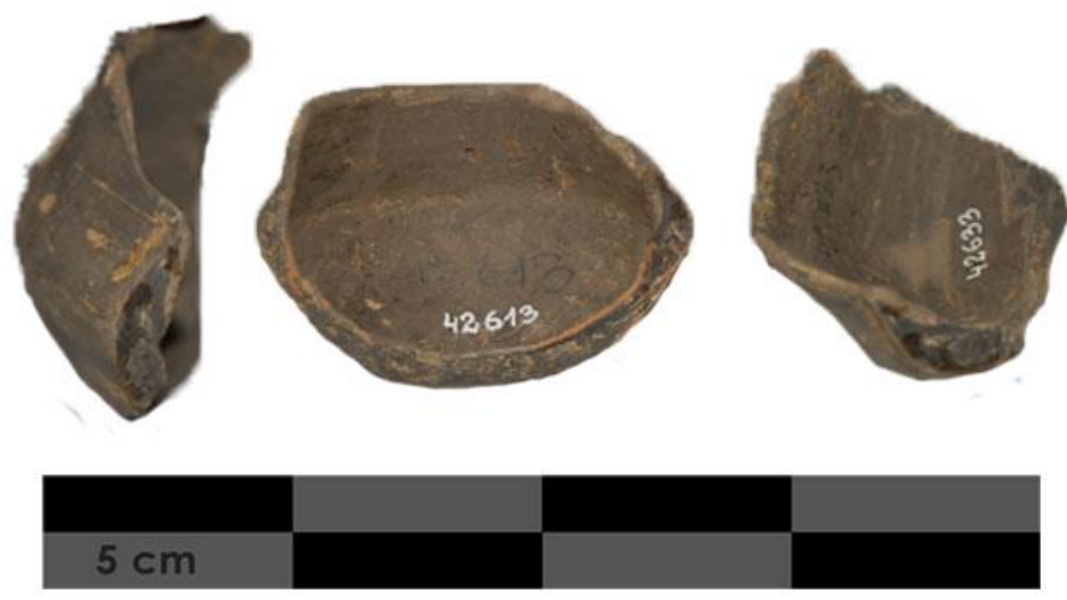

Tabla 37. Poluloptaste šolje na kojima se ne ističe dno, stratum II (Dž. Brigić)

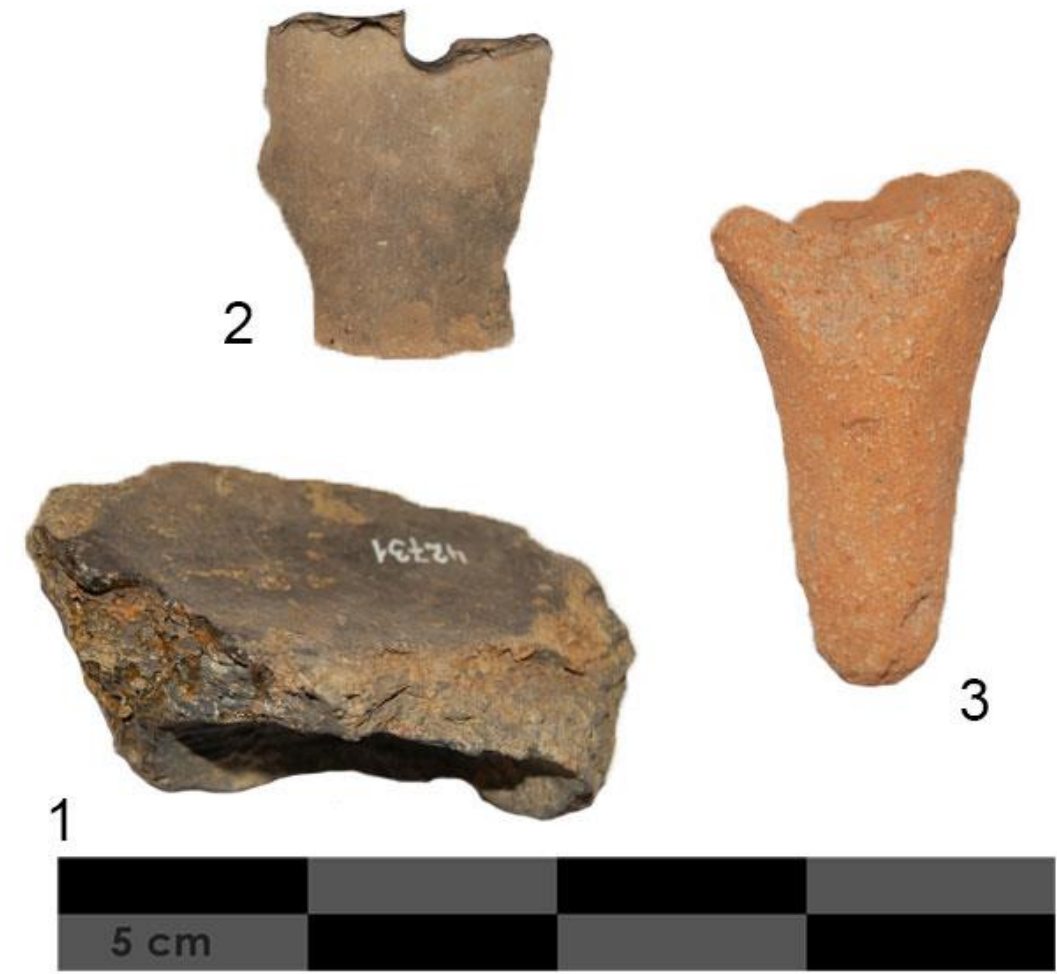

Tabla 38. Posude na višoj ili nižoj šupljoj nozi, stratum II: 1 - cilindrična; 2 - zvonolika; 3 - visoka šuplja noga (snimio Dž. Brigić) 

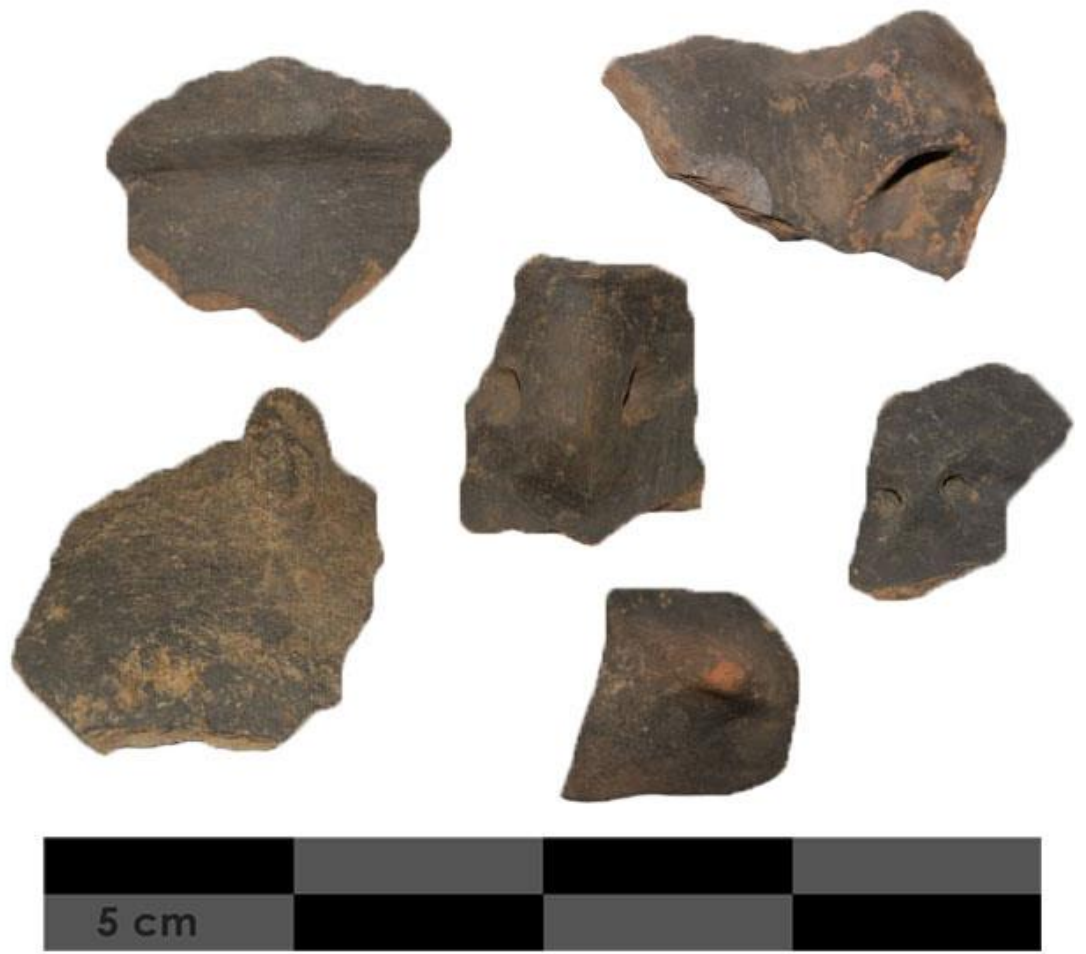

Tabla 39. Drške iz stratuma II (snimio Dž. Brigić)

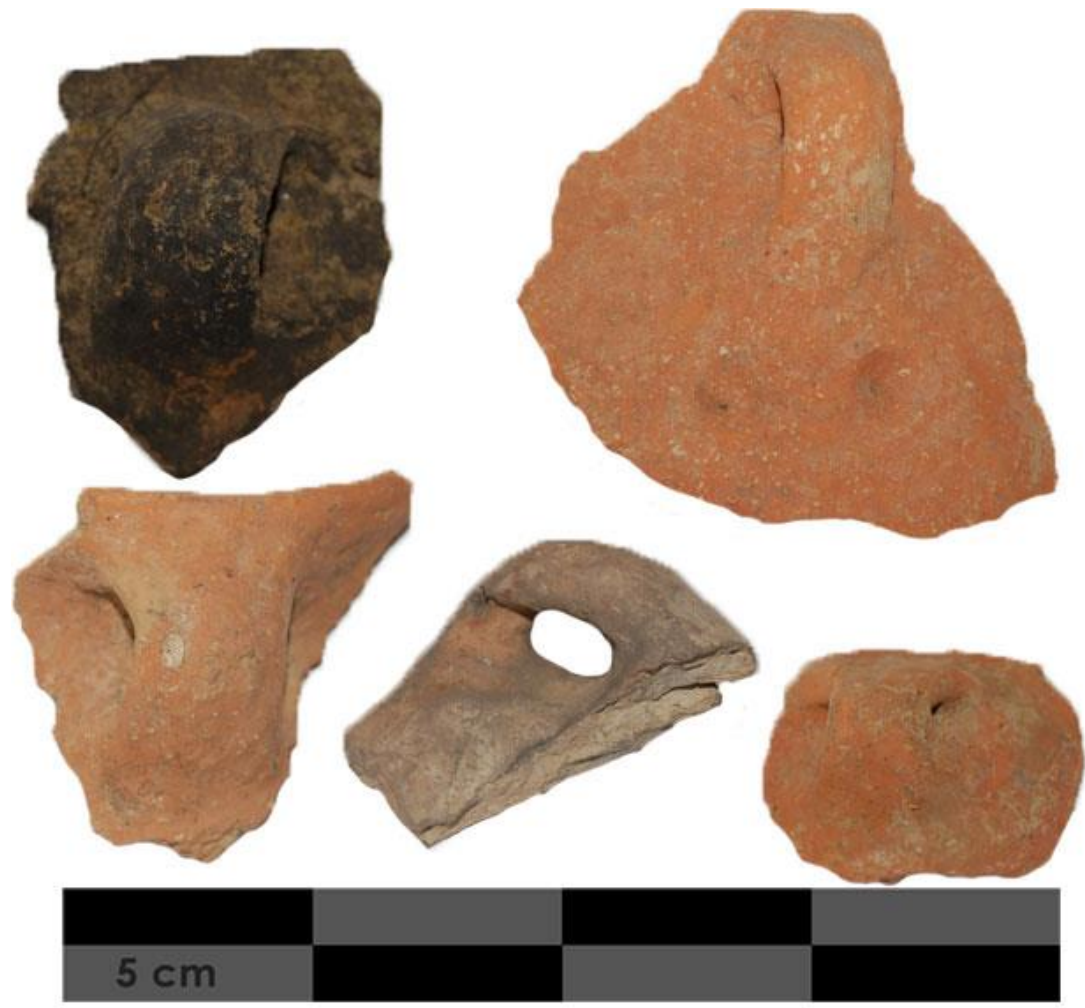

Tabla 40. Drške iz stratuma II (snimio Dž. Brigić) 

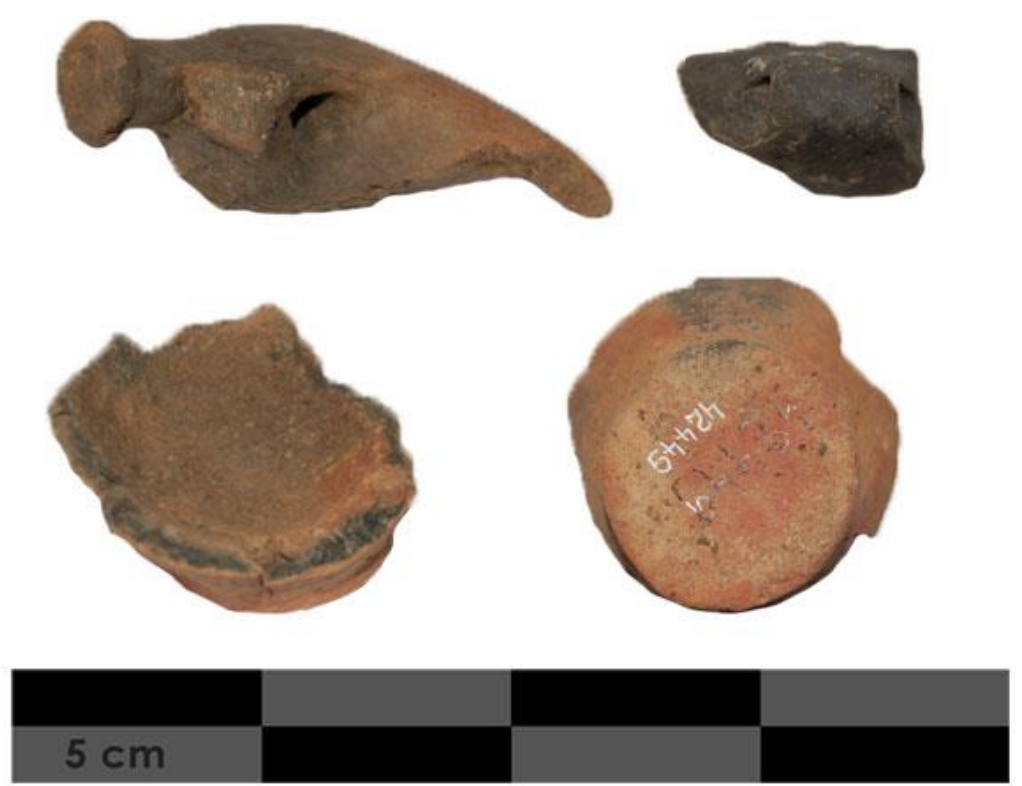

Tabla 41. Keramika iz stratuma I (snimio Dž. Brigić)
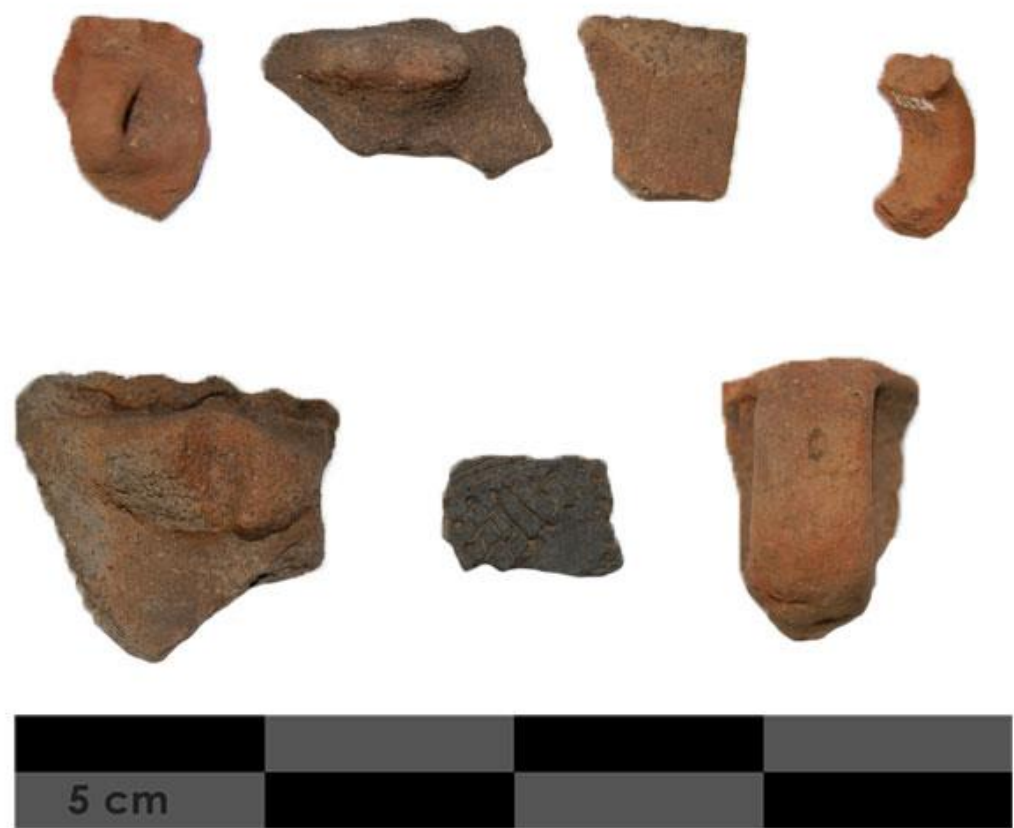

Tabla 42. Keramika iz stratuma I (snimio Dž. Brigić) 


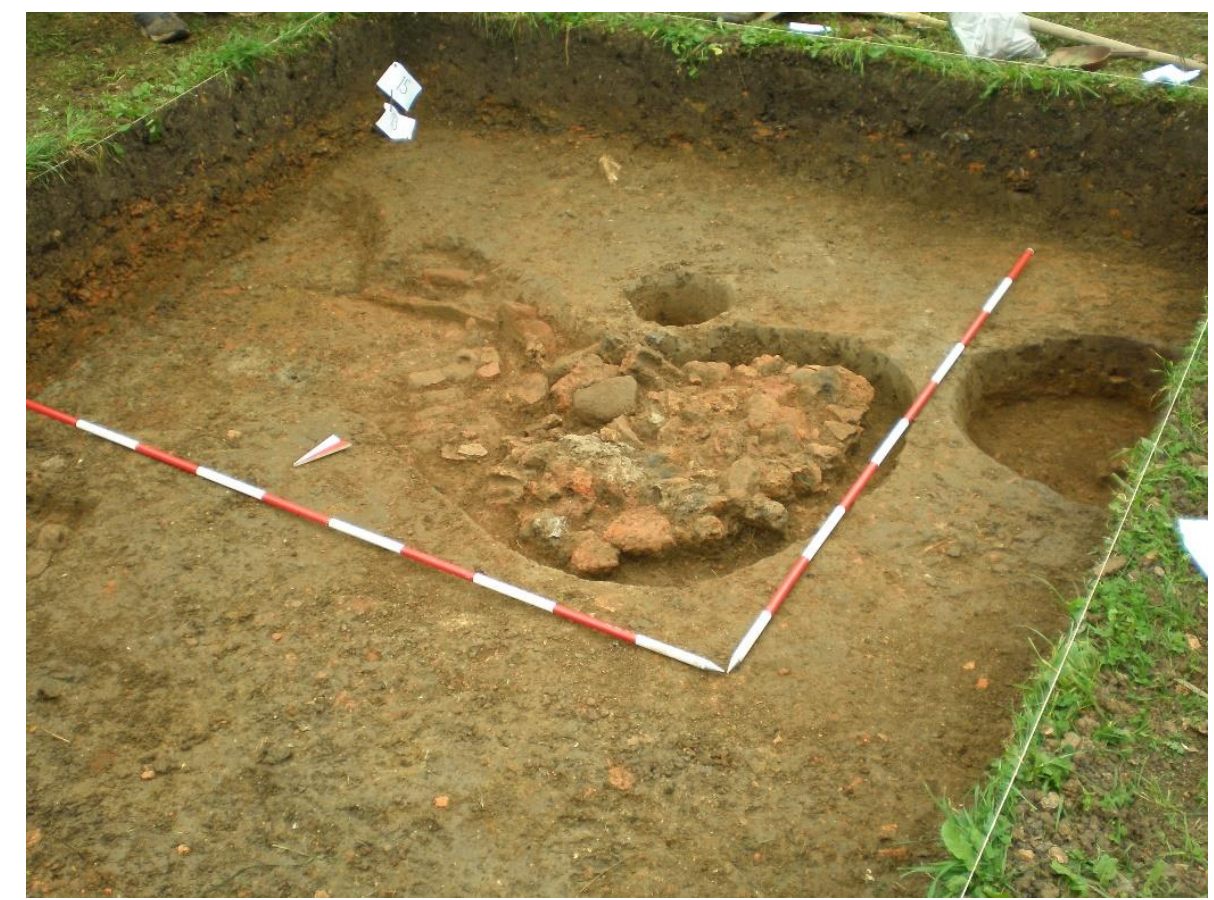

Tabla 43. Ostaci kalotne peći sa istraživanja 2007./2009. (G. Tiefengraber)

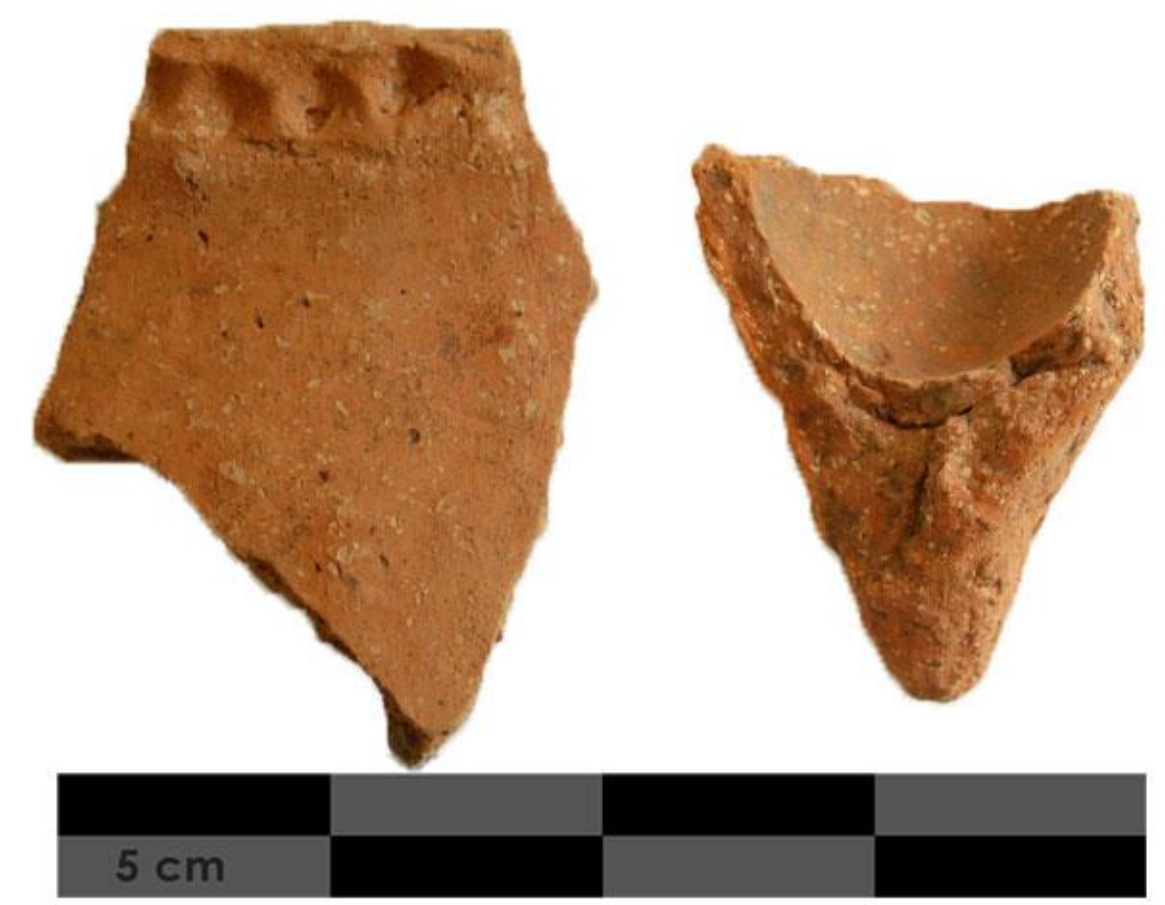

Tabla 44. Safetova bašča, otkopni sloj IV (snimio Dž. Brigić) 


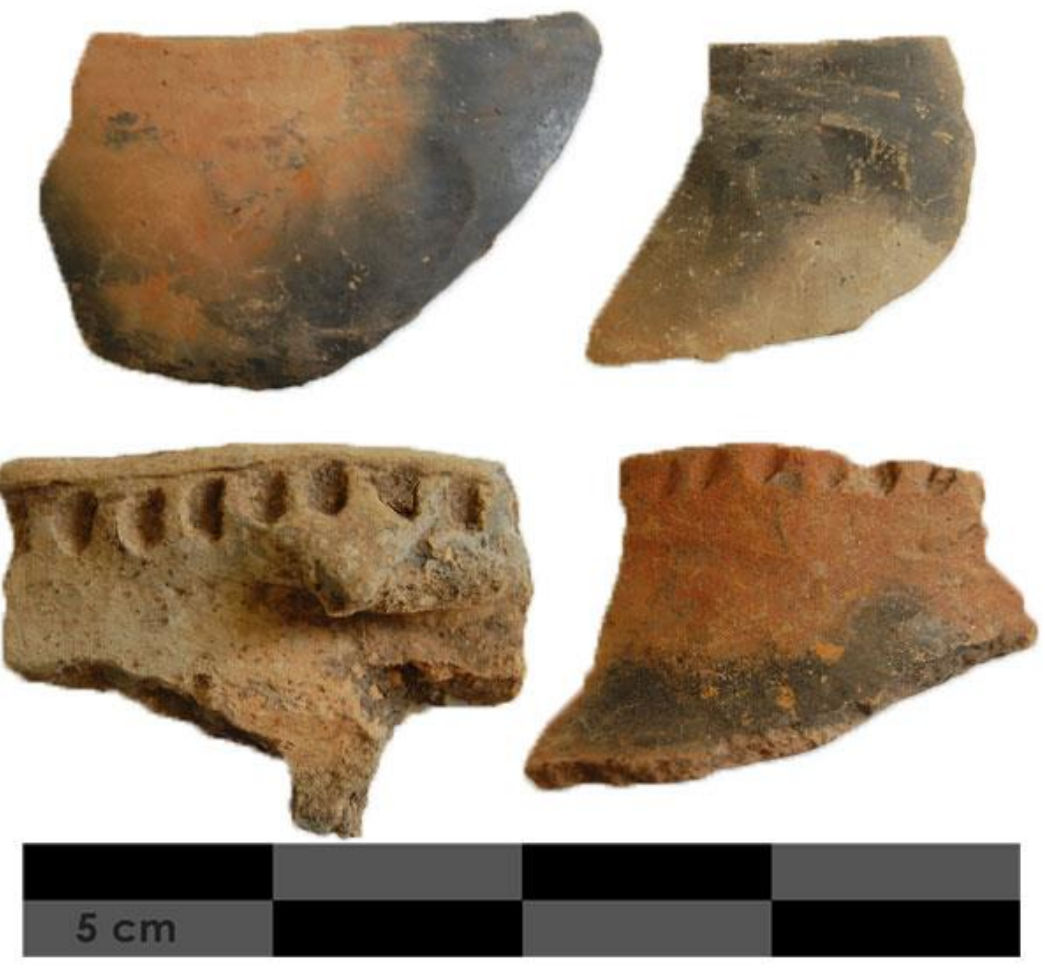

Tabla 45. Safetova bašča, otkopni sloj IV (snimio Dž. Brigić)
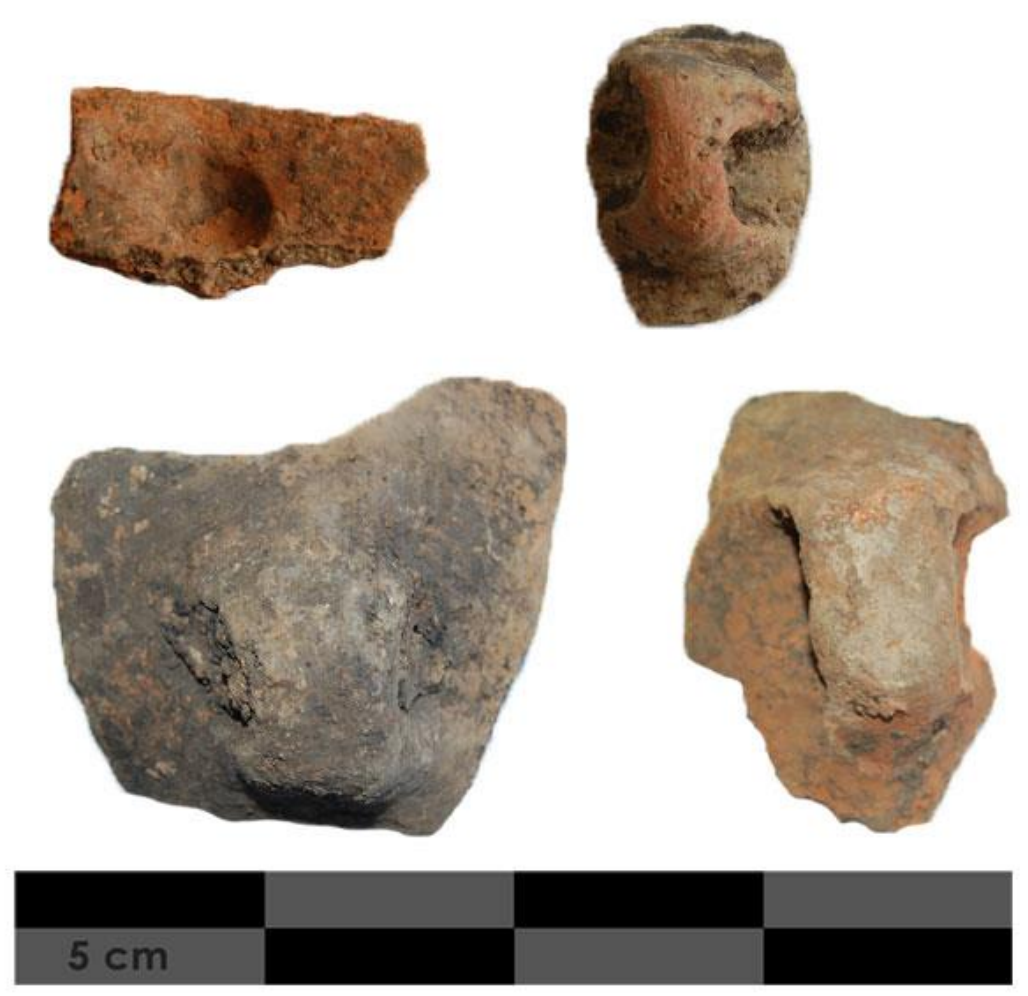

Tabla 46. Safetova bašča, otkopni sloj V (snimio Dž. Brigić) 


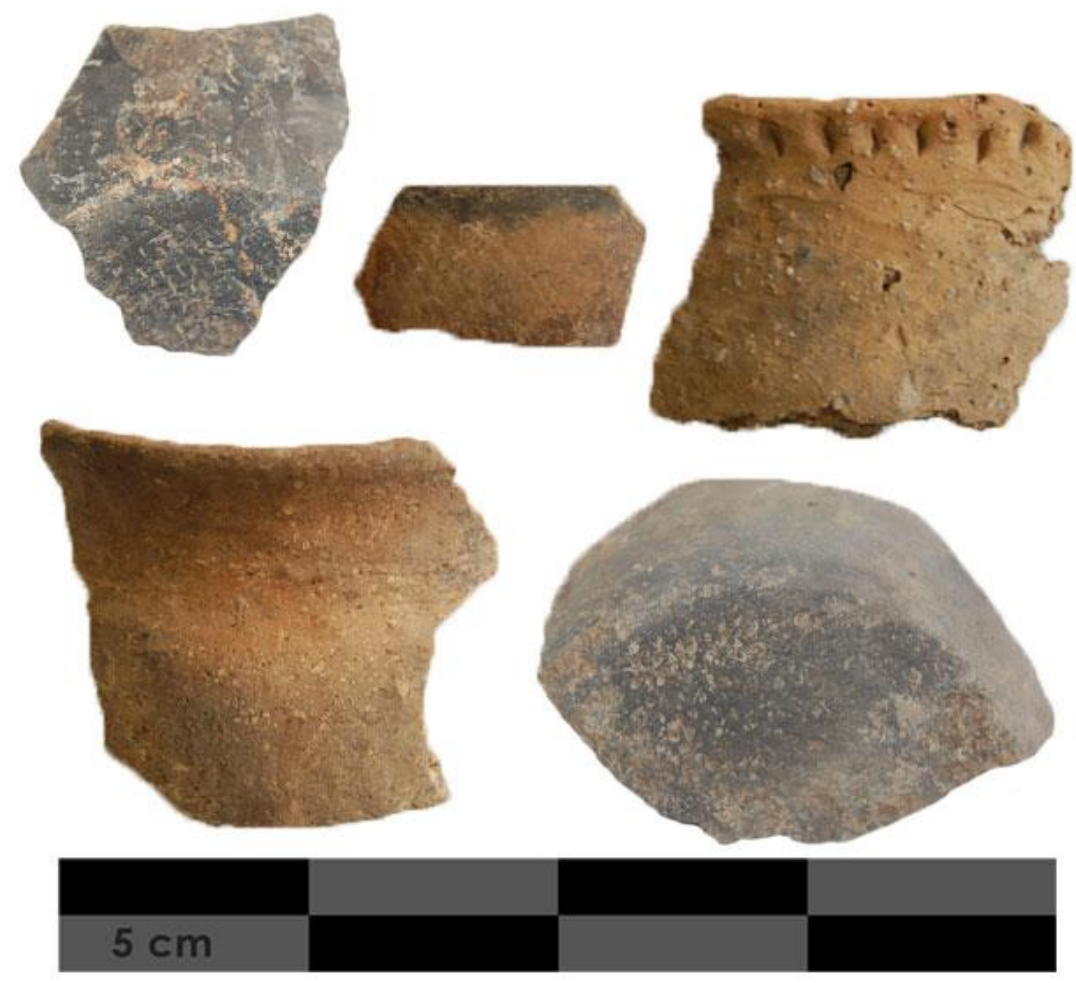

Tabla 47. Safetova bašča, otkopni sloj VI (snimio Dž. Brigić)

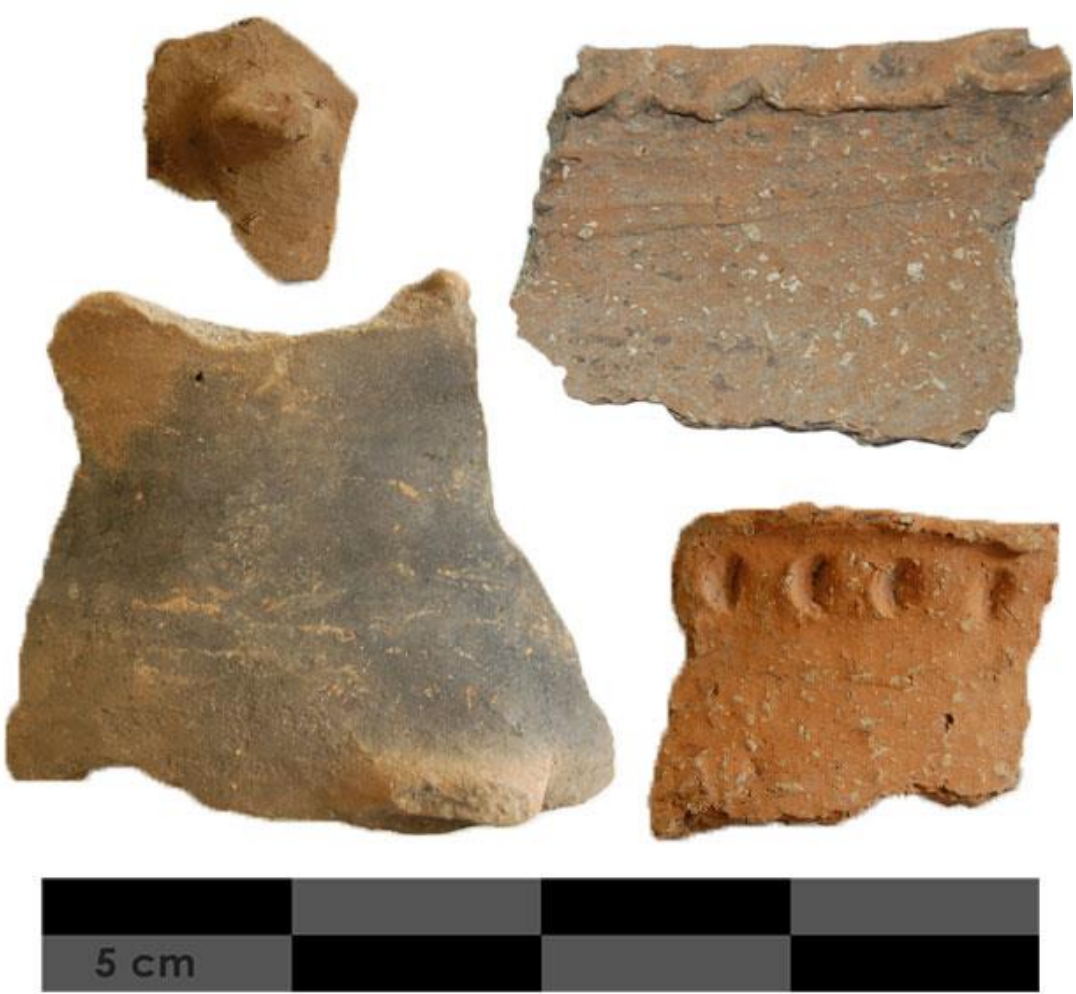

Tabla 48. Safetova bašča, otkopni sloj VII (snimio Dž. Brigić) 


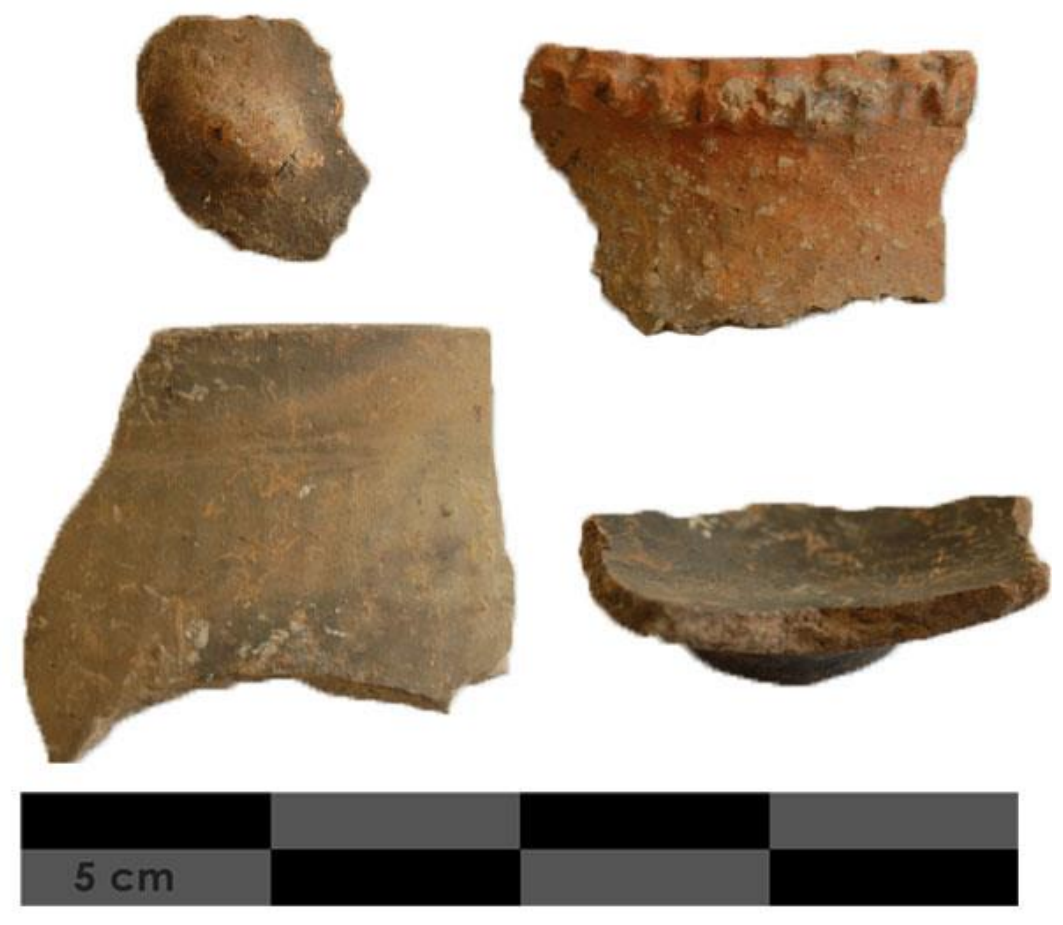

Tabla 49. Safetova bašča, otkopni sloj VIII (snimio Dž. Brigić)

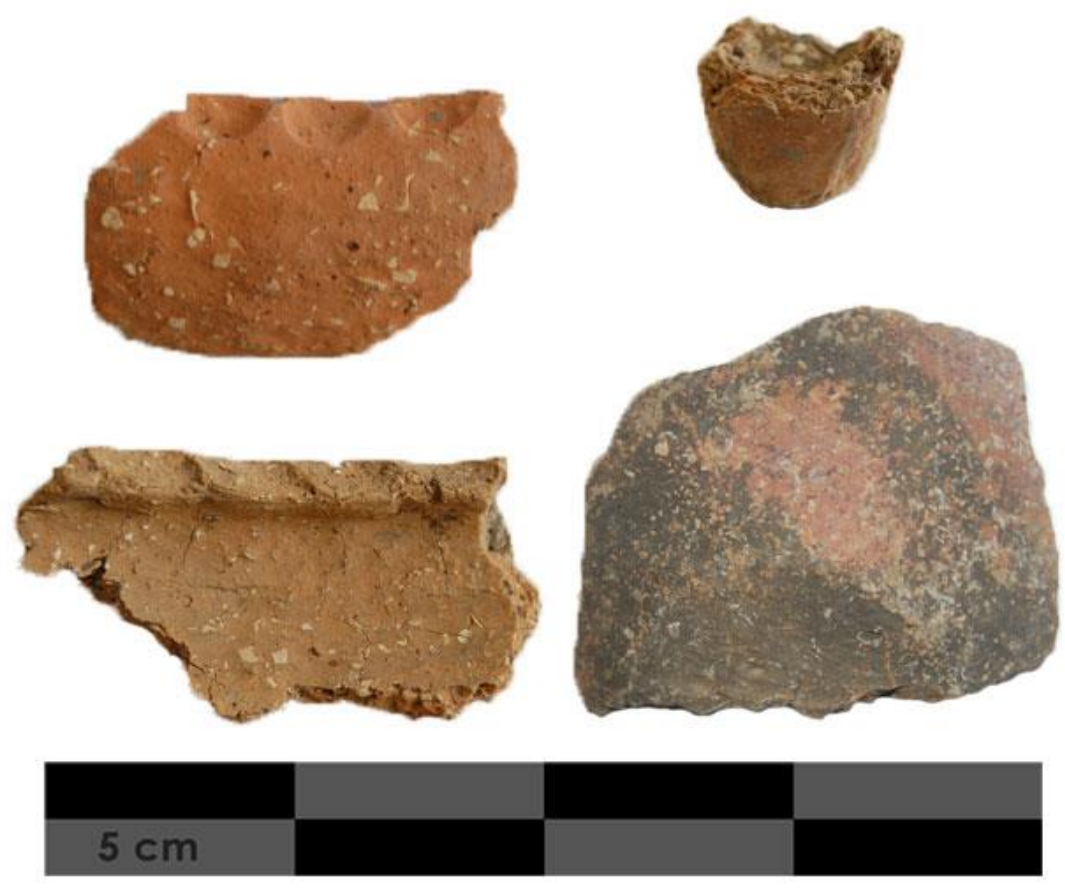

Tabla 50. Safetova bašča, otkopni sloj IX (snimio Dž. Brigić) 

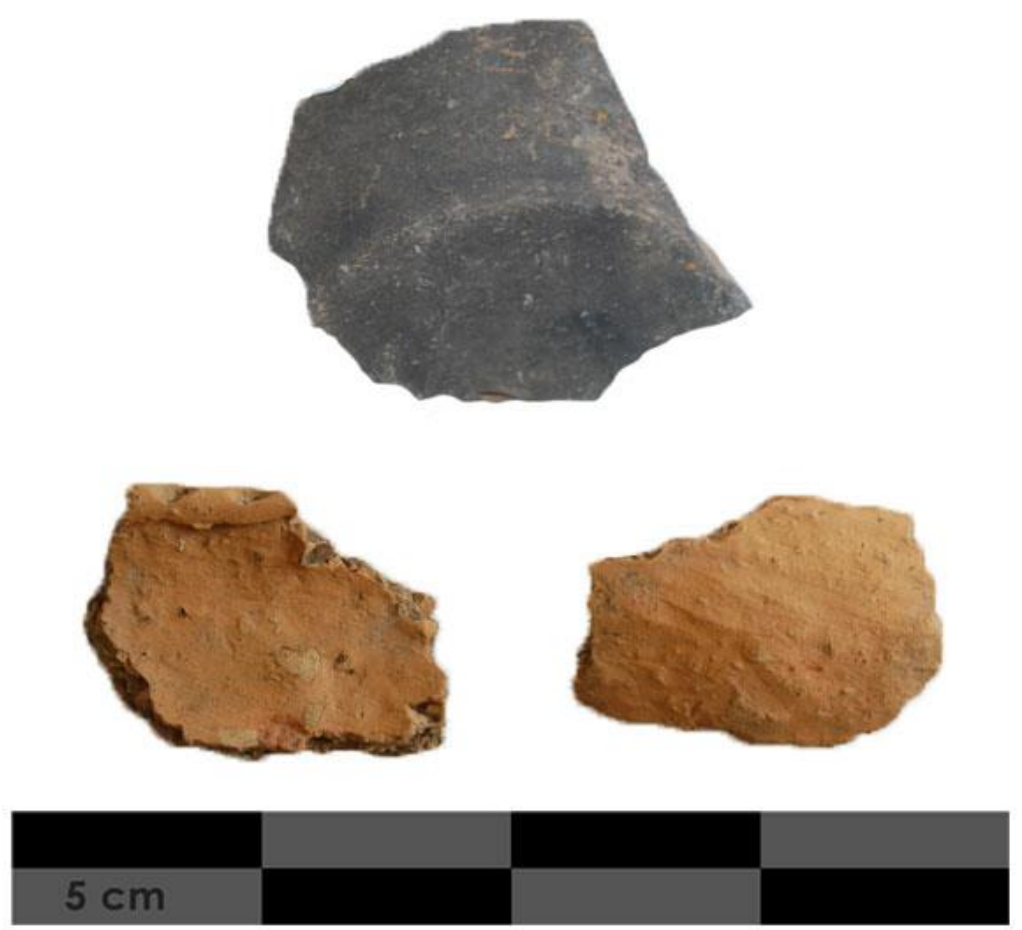

Tabla 51. Safetova bašča, otkopni sloj X (snimio Dž. Brigić)

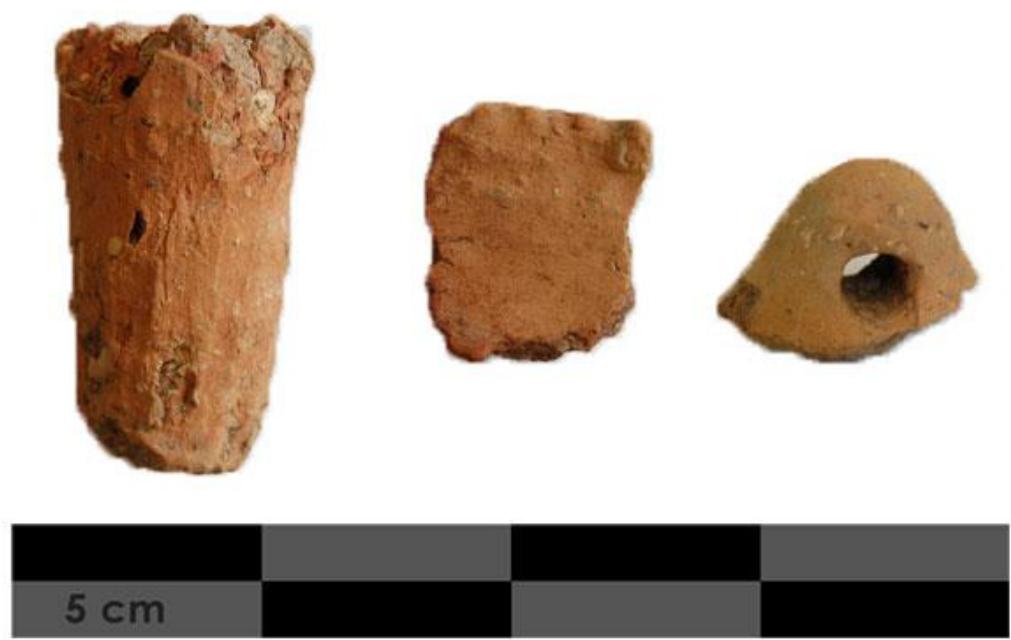

Tabla 52. Safetova bašča, otkopni sloj XI (snimio Dž. Brigić) 


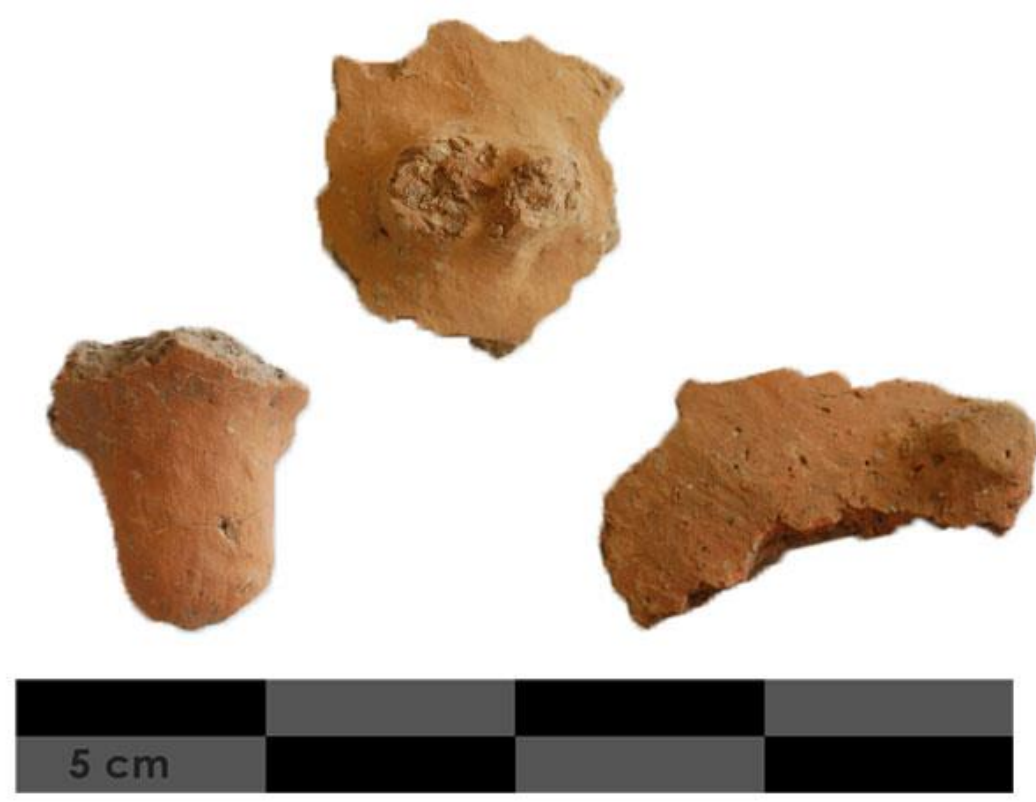

Tabla 53. Safetova bašča, otkopni sloj XII (snimio Dž. Brigić)

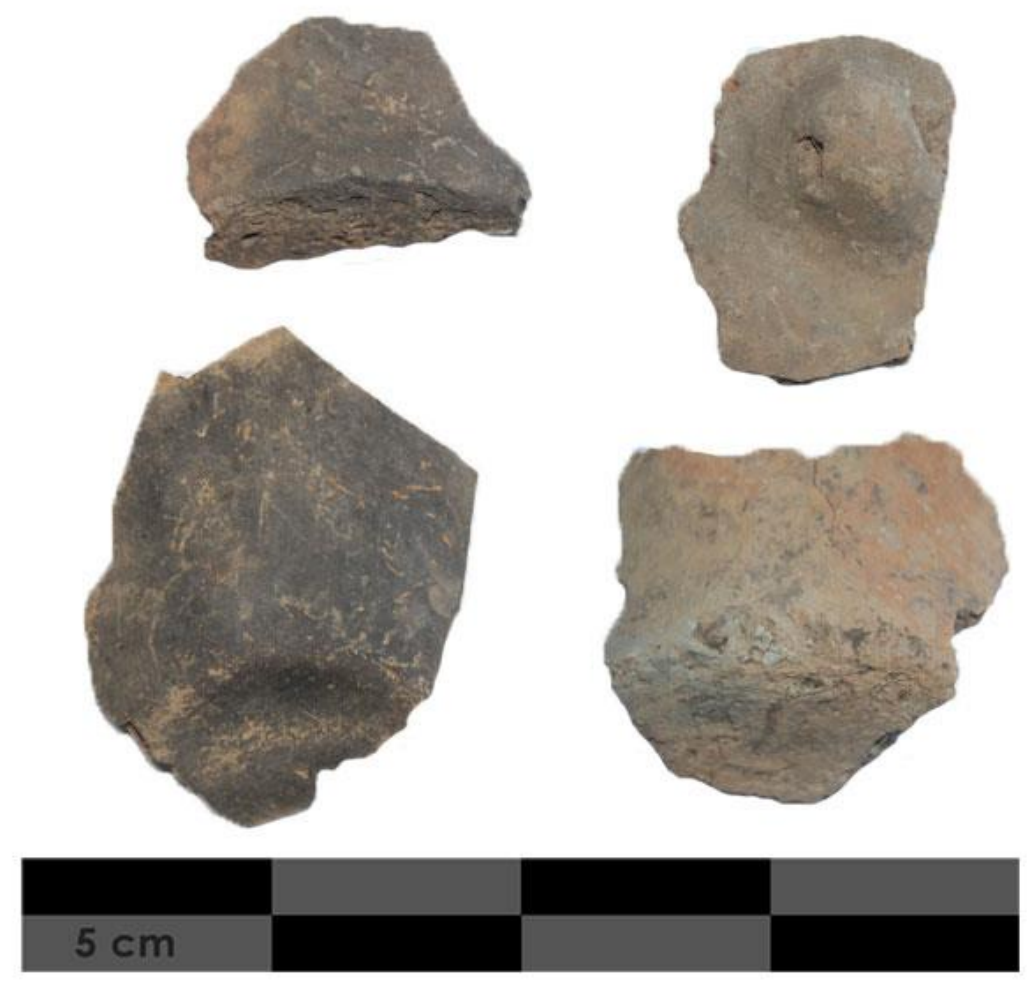

Tabla 54. Safetova bašča, otkopni sloj XIII (snimio Dž. Brigić) 


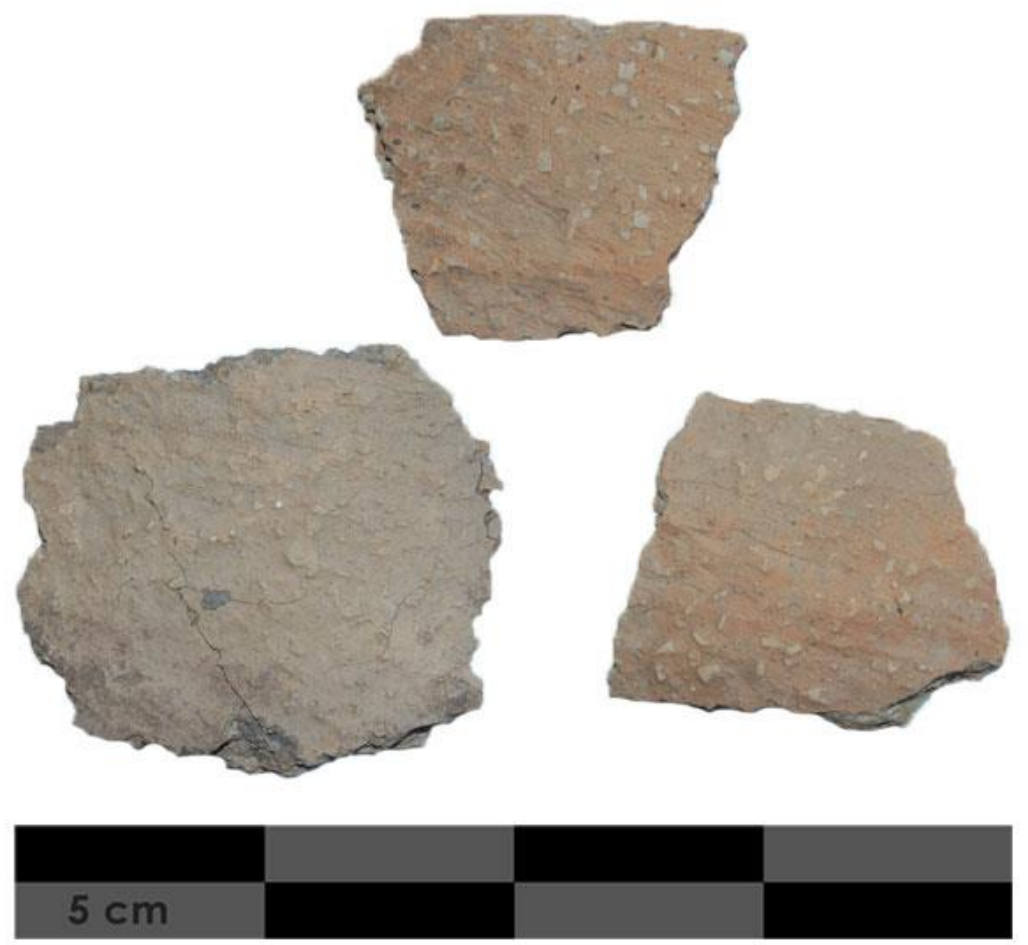

Tabla 55. Safetova bašča, otkopni sloj XIV (snimio Dž. Brigić)
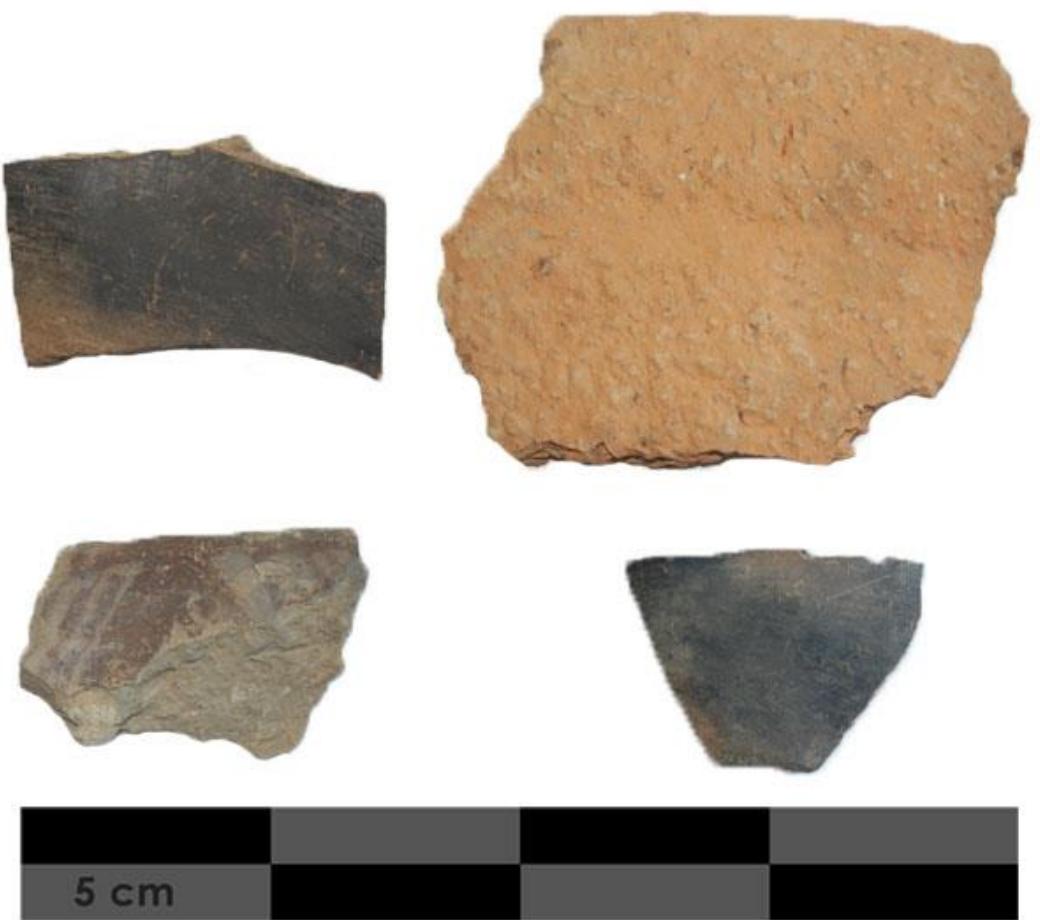

Tabla 56. Safetova bašča, otkopni sloj XV (snimio Dž. Brigić) 


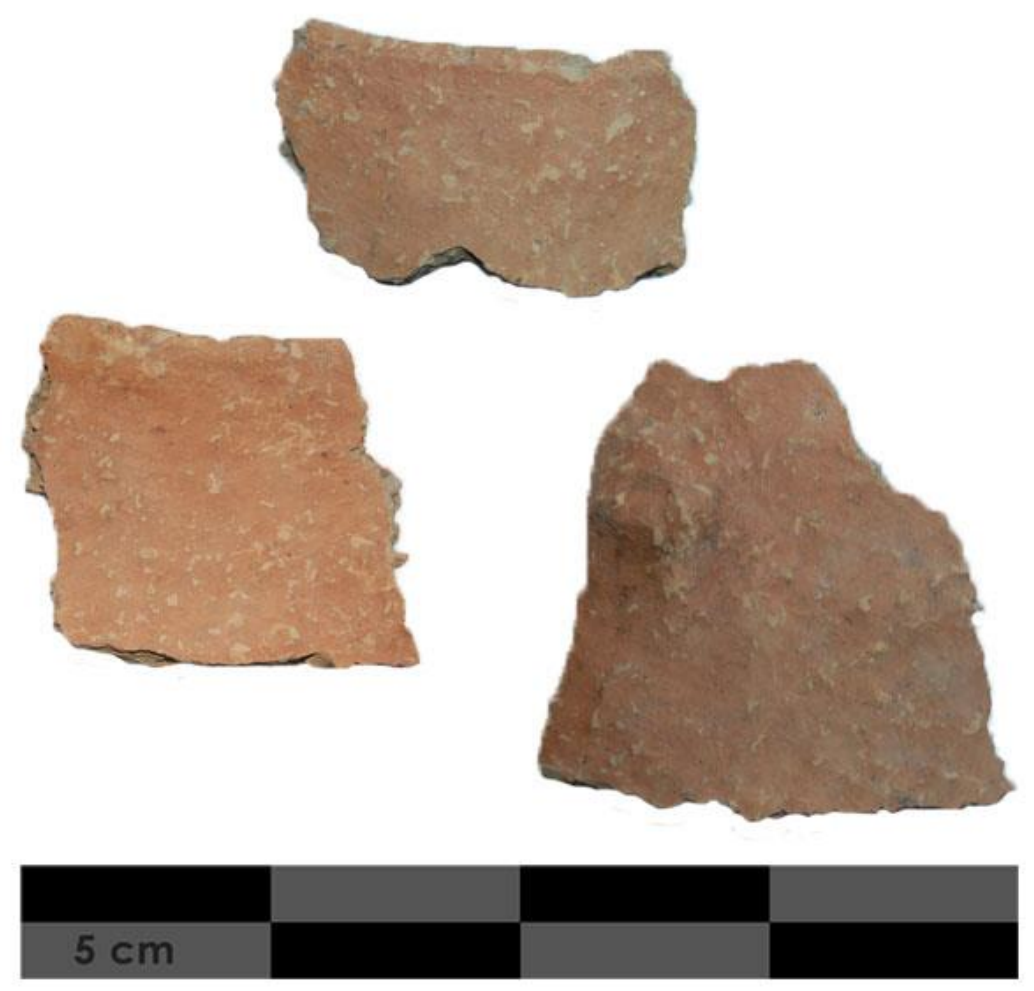

Tabla 57. Safetova bašča, otkopni sloj XVI (snimio Dž. Brigić)
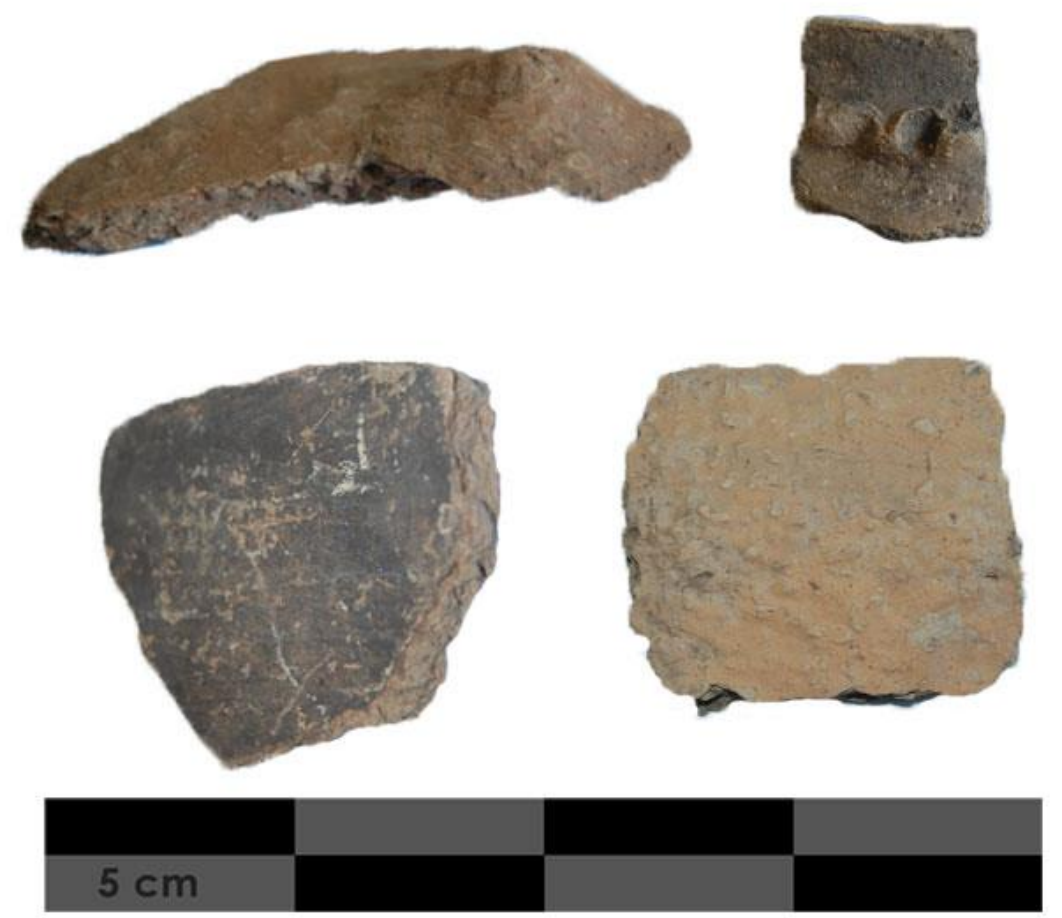

Tabla 58. Safetova bašča, otkopni sloj XVII (snimio Dž. Brigić) 


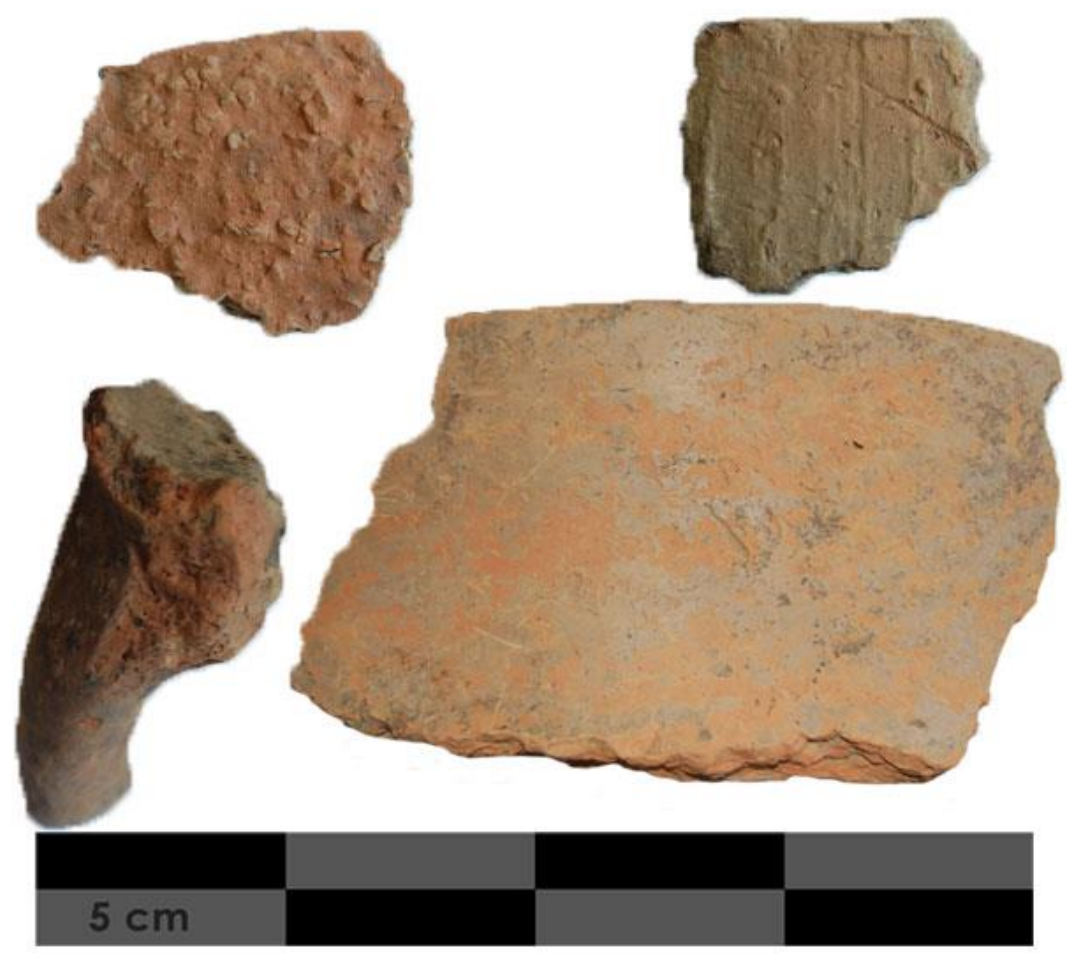

Tabla 59. Safetova bašča, otkopni sloj XVIII (snimio Dž. Brigić)

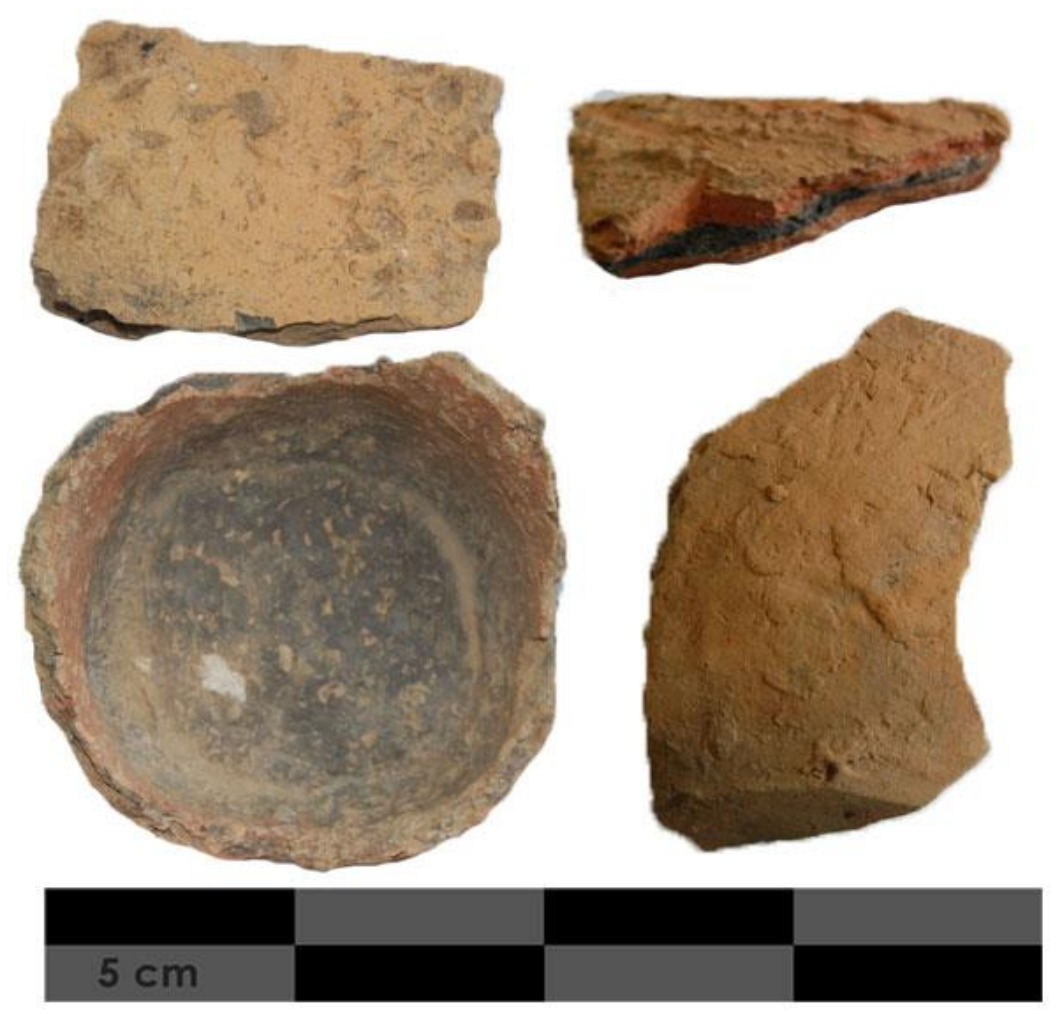

Tabla 60. Safetova bašča, kontrolni rov uz istočni profil sonde (snimio Dž. Brigić) 

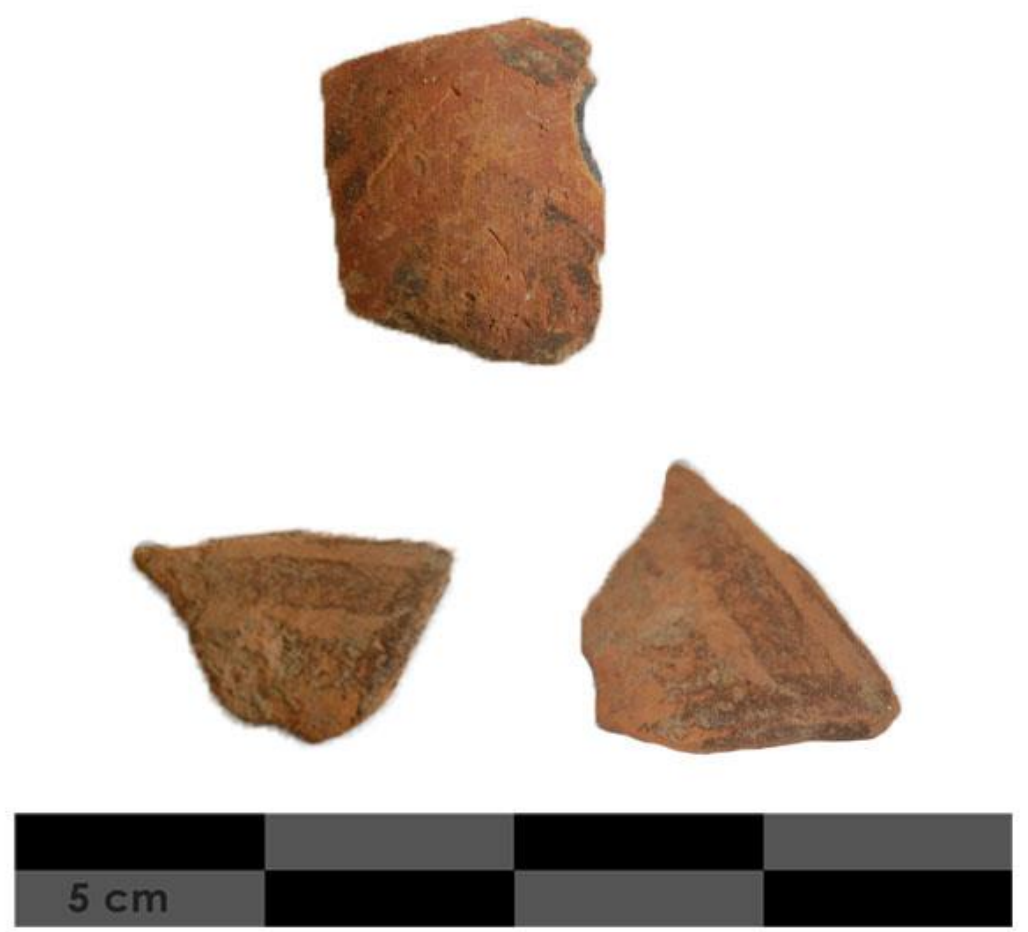

Tabla 61. Safetova bašča, slikana keramika iz kontrolnog rova (snimio Dž. Brigić)

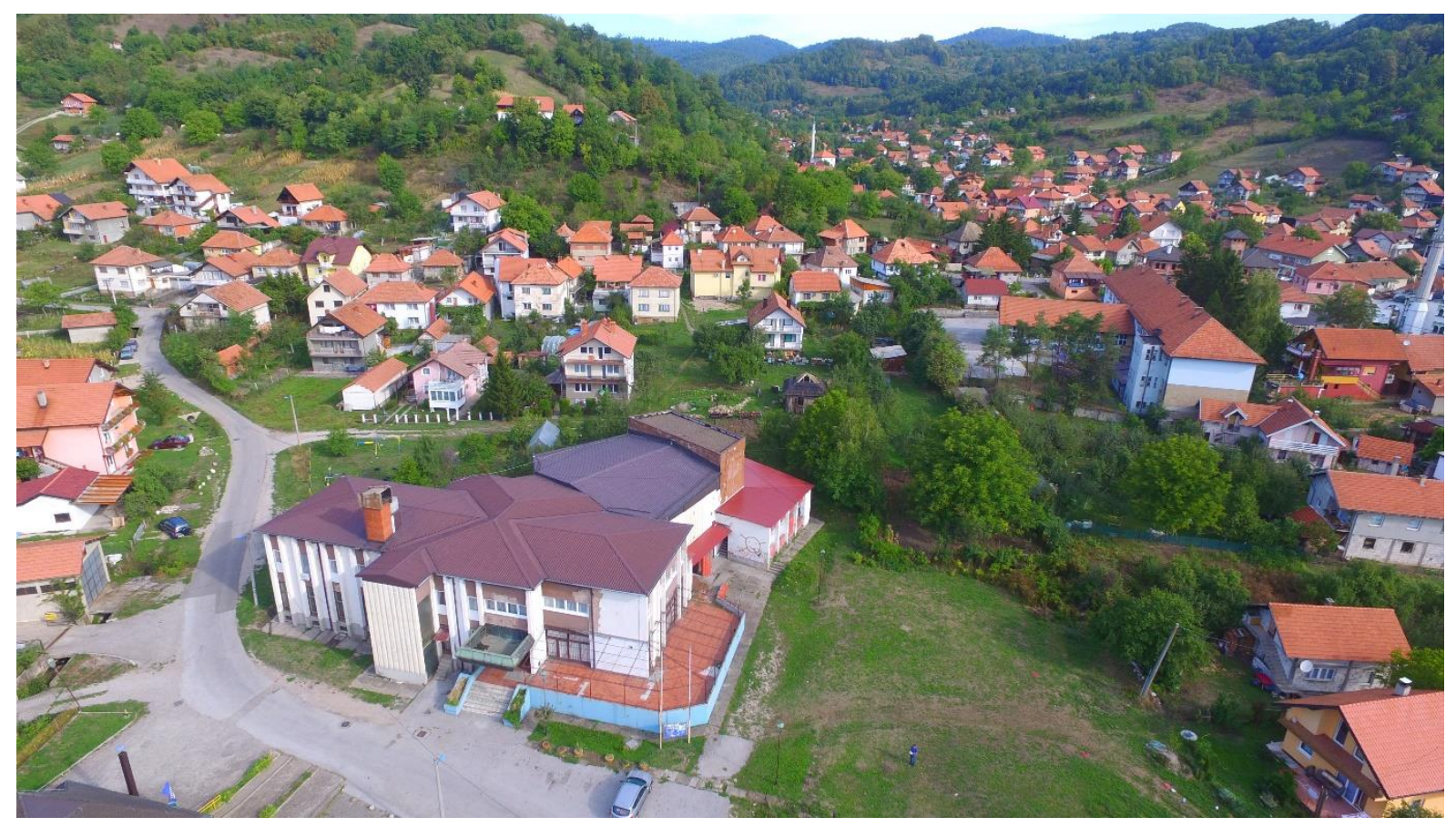

Tabla 62. Lokalitet Gornja Tuzla (snimio M. Burić) 


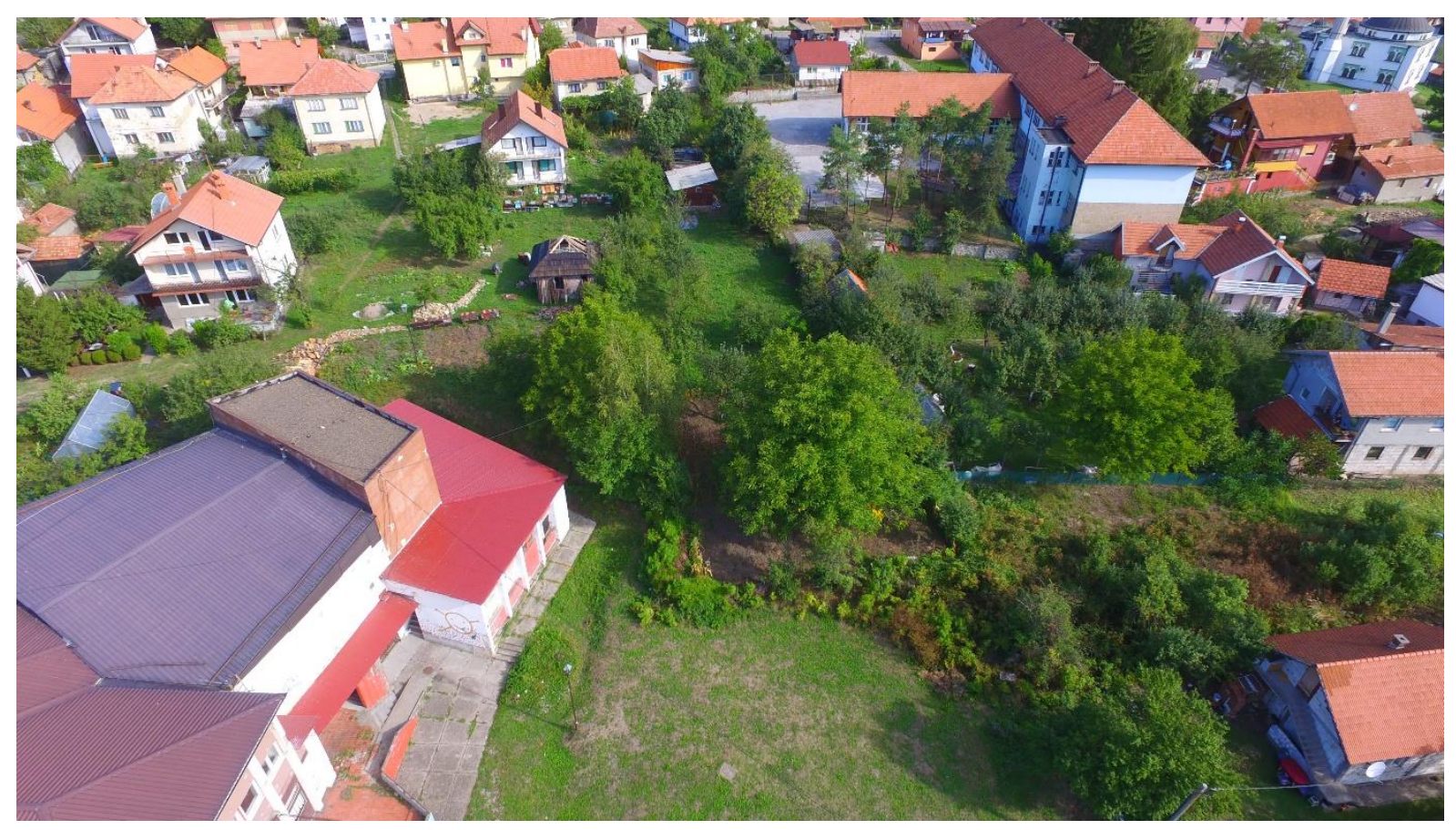

Tabla 63. Katastarske čestice 615, 616, 617, 618, 619 - lokacija otvorenih sondi 2007./2018. (snimio M. Burić)

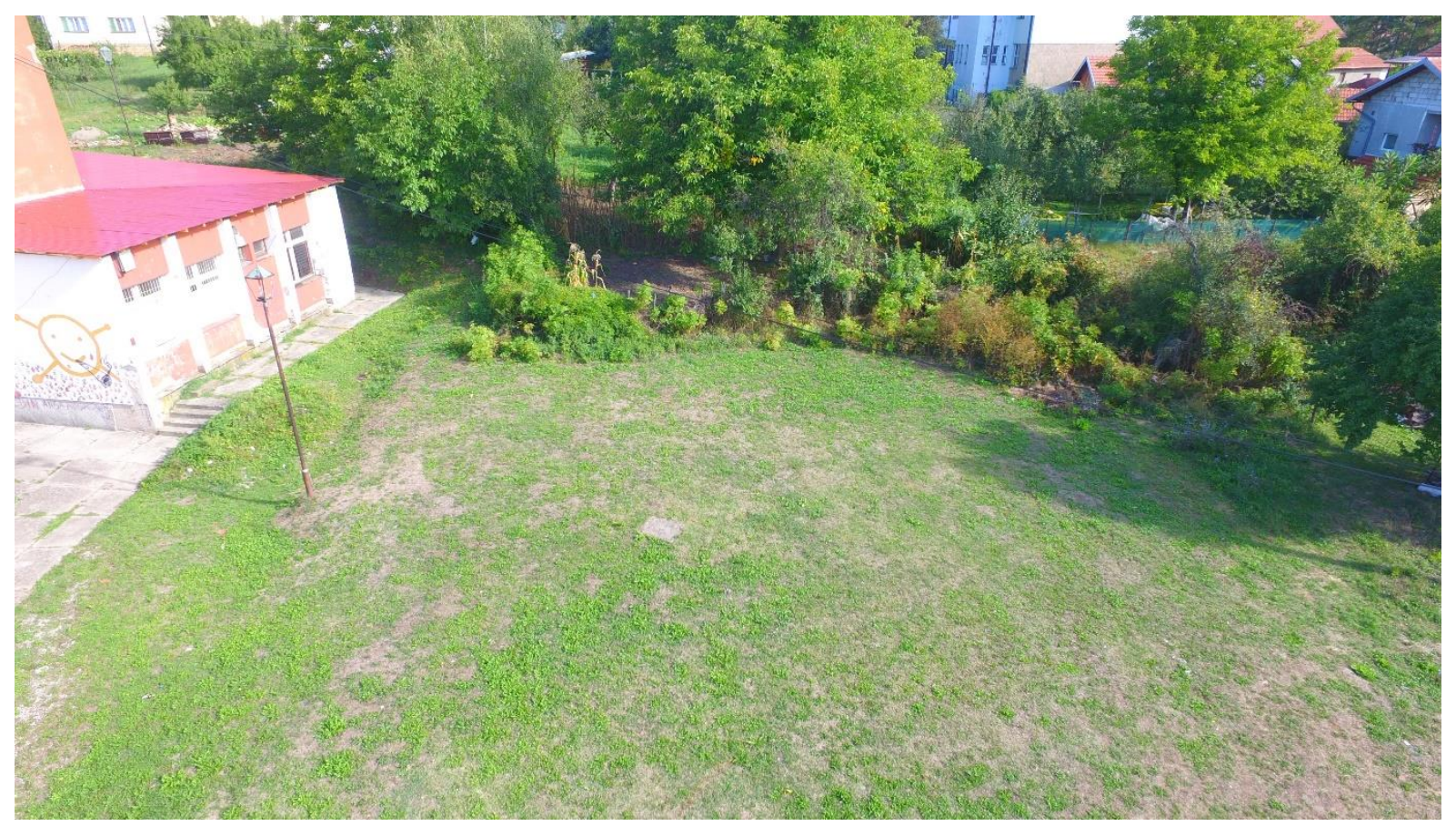

Tabla 64. Bliži pogled na lokaciju sonde I-2018 (snimio M. Burić) 

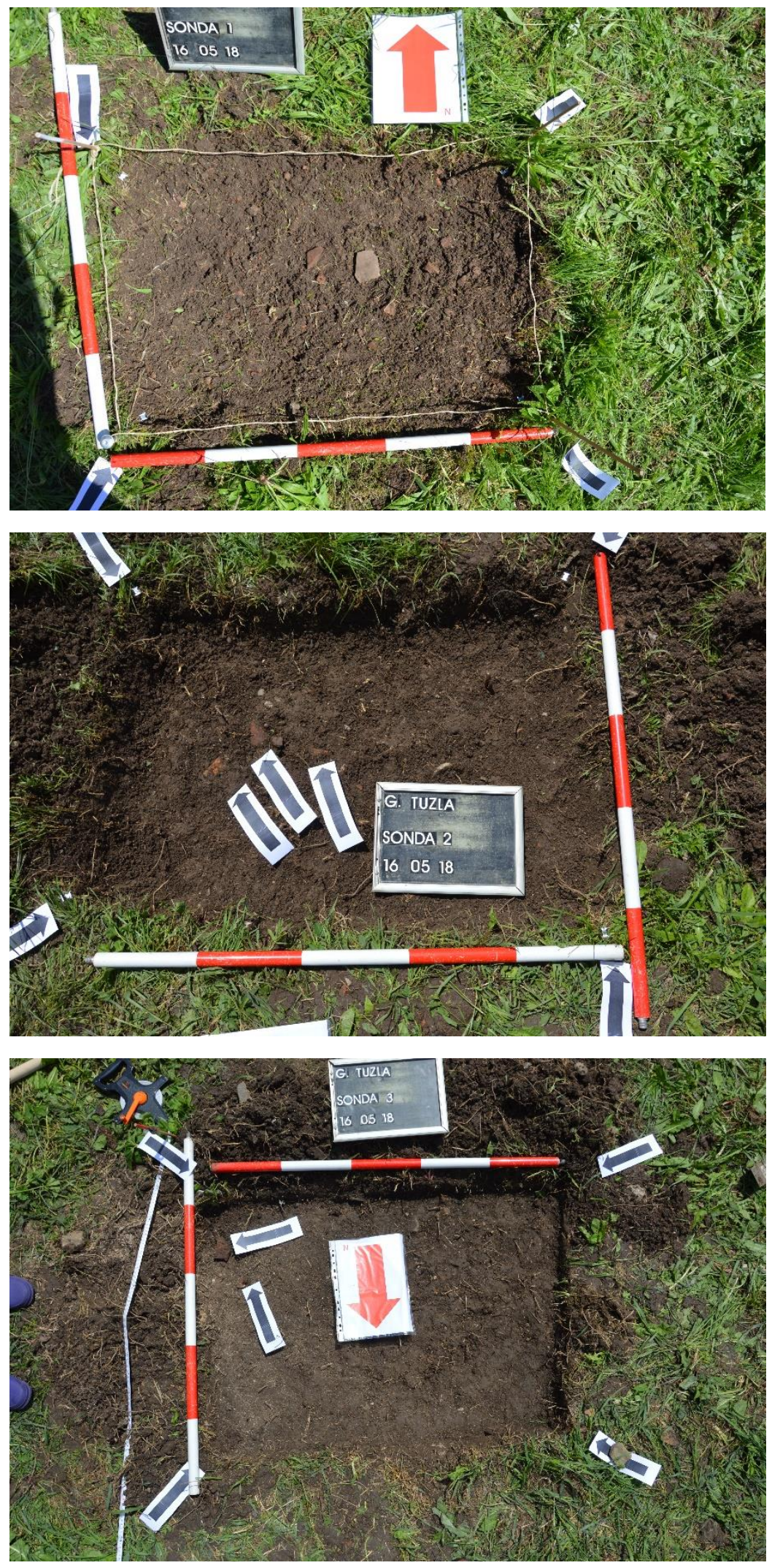

Tabla 65. Probne sonde (snimila E. Hantalašević) 


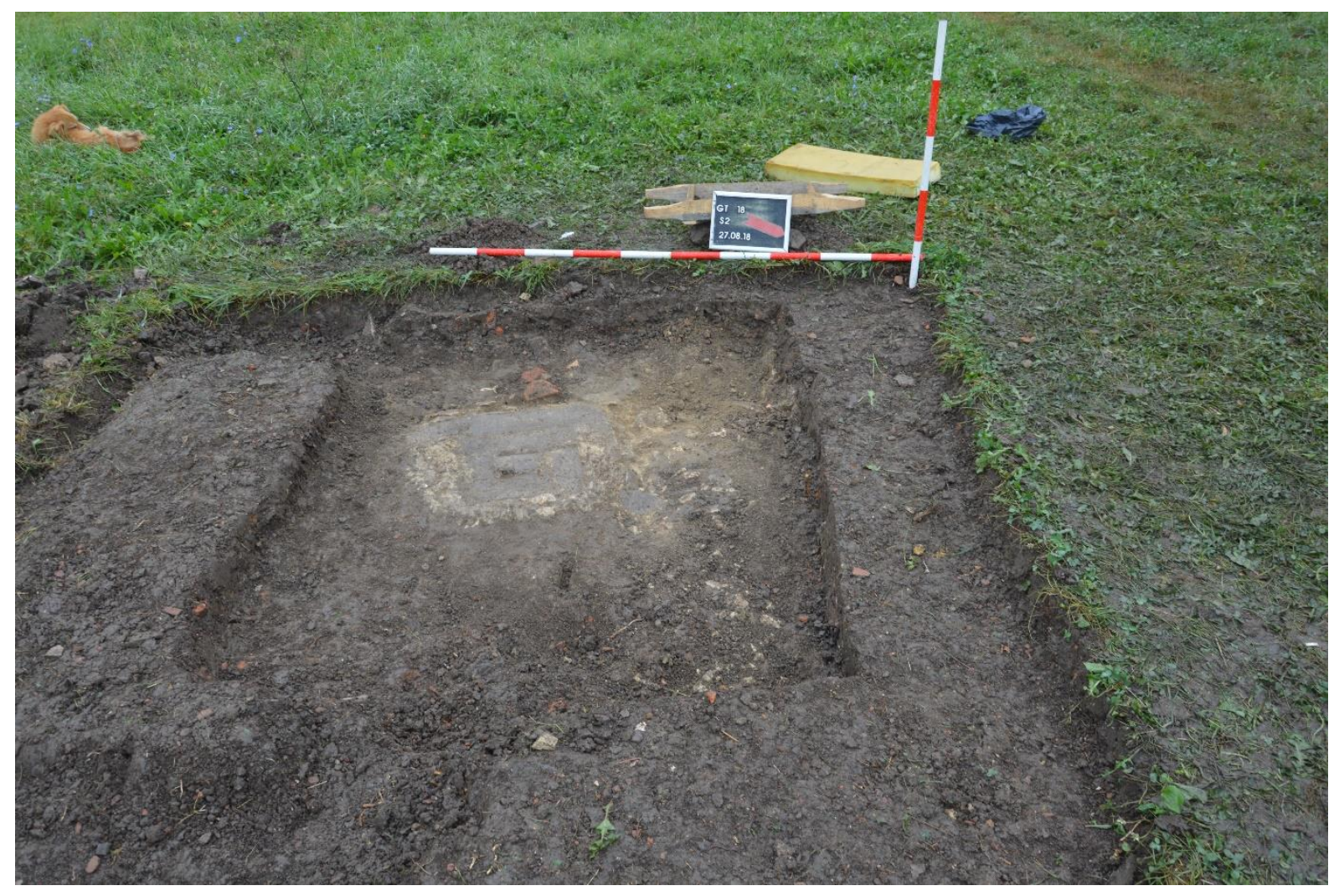

Tabla 66. Sonda II-2018 (snimila M. Turkmanović)

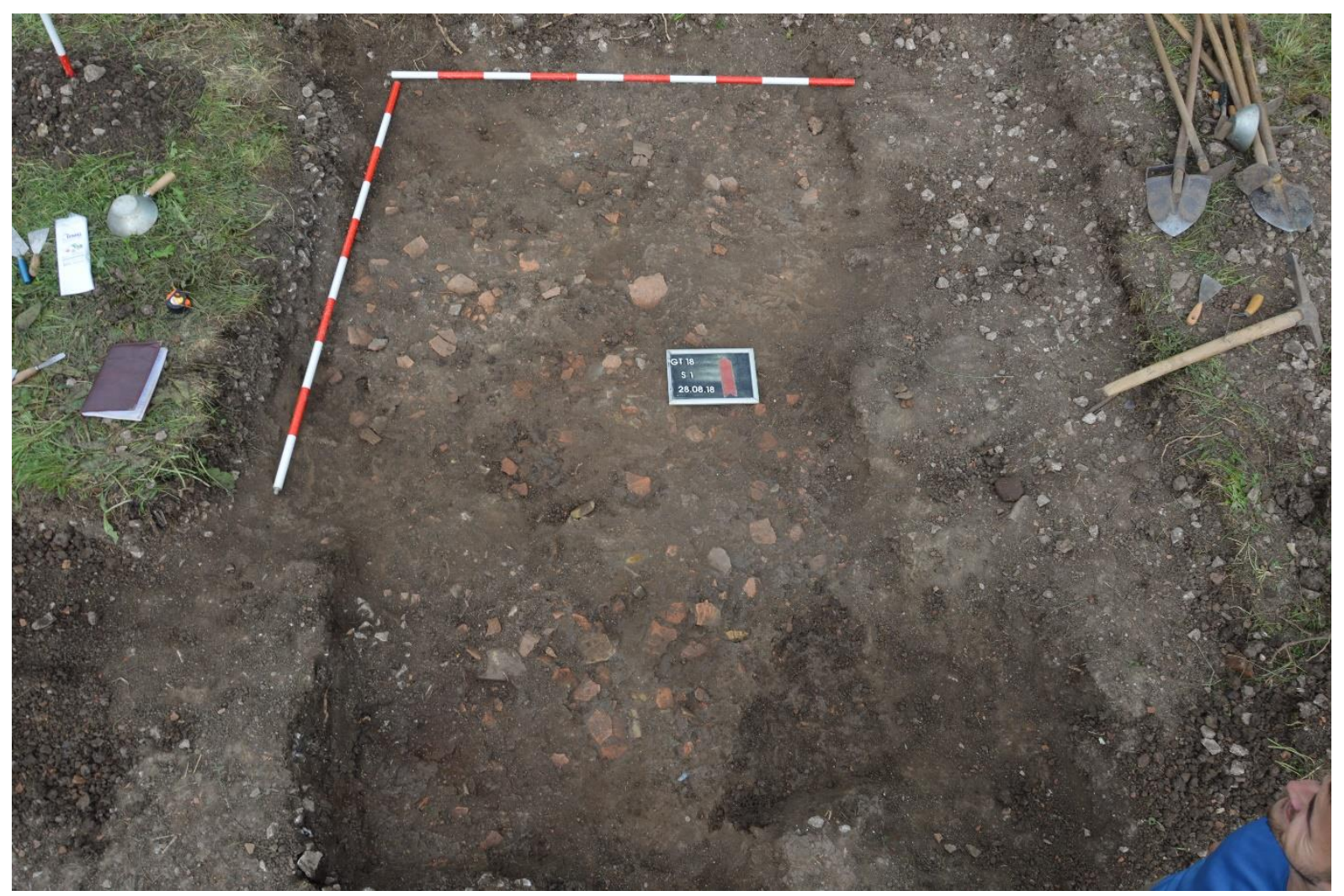

Tabla 67. Sonda I-2018 (snimila M. Turkmanović) 


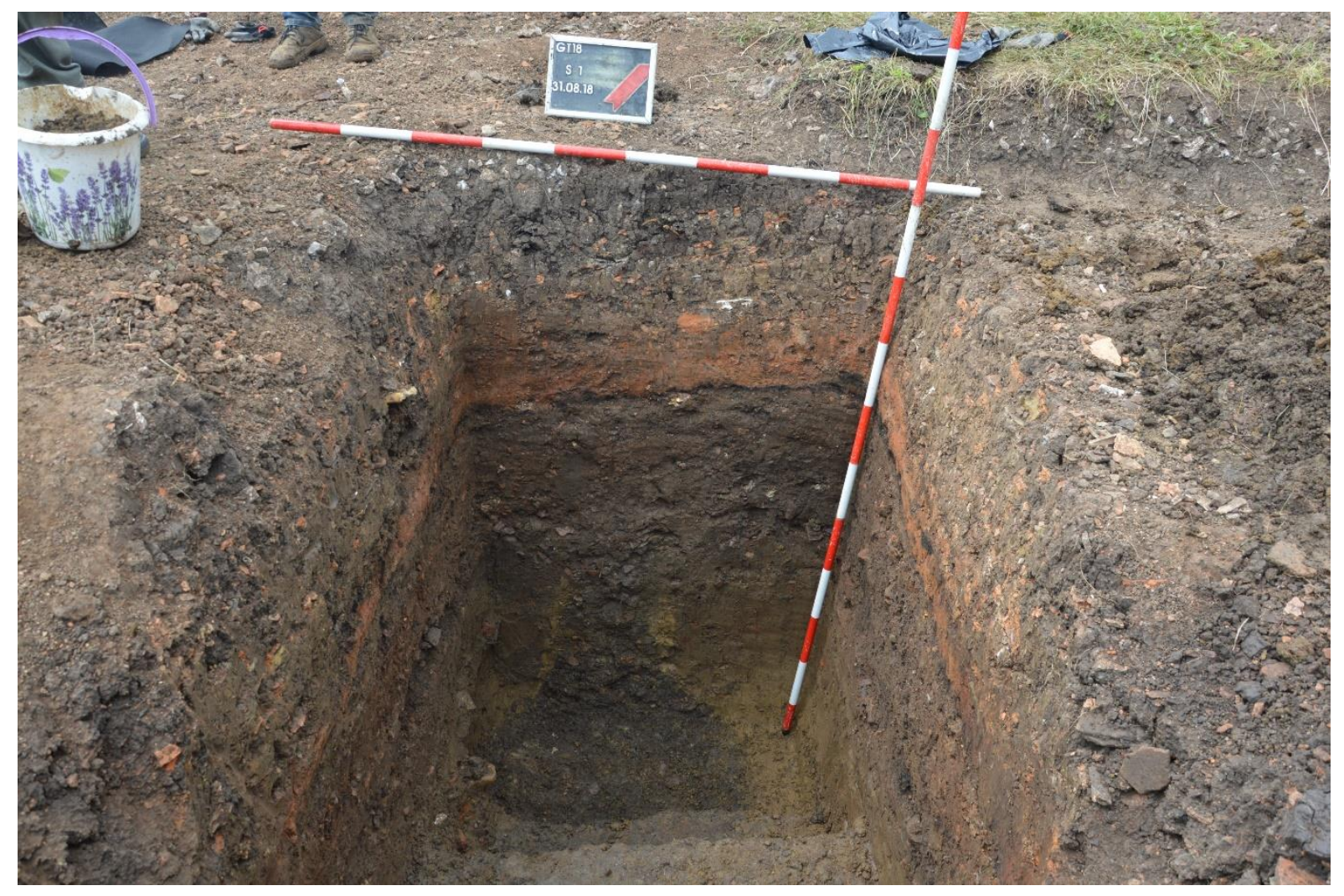

Tabla 68. Vertikalna stratigrafija sonde I-2018 (snimila M. Turkmanović)

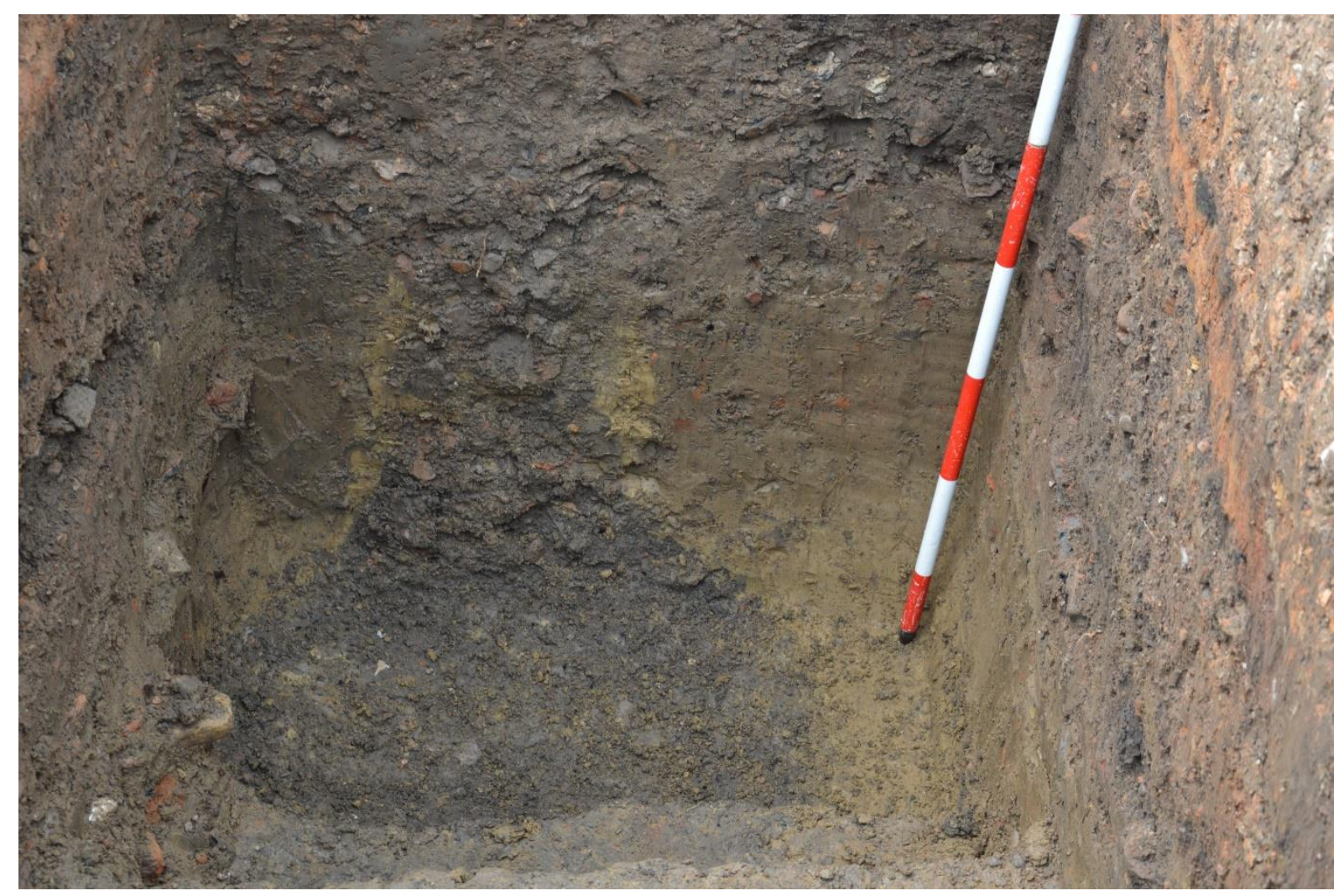

Tabla 69. Jama ukopana u zdravicu, sonda I-2018 (snimila M. Turkmanović) 


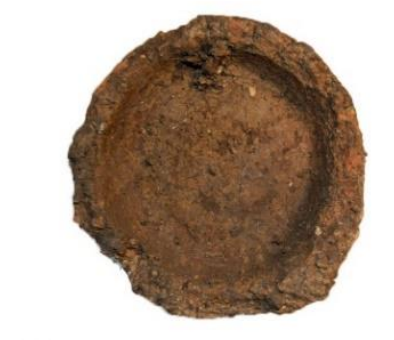

S1

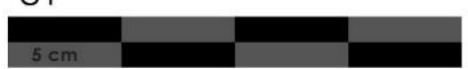

\section{S1}
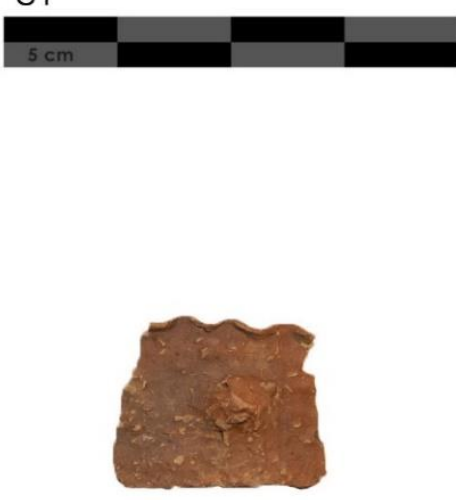

S1
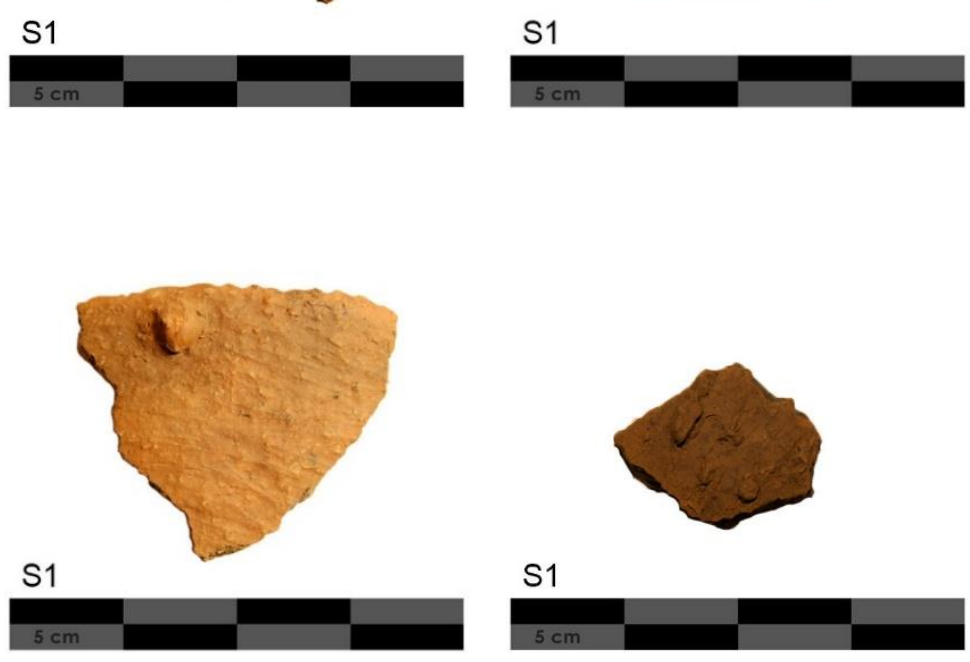

S1

S1
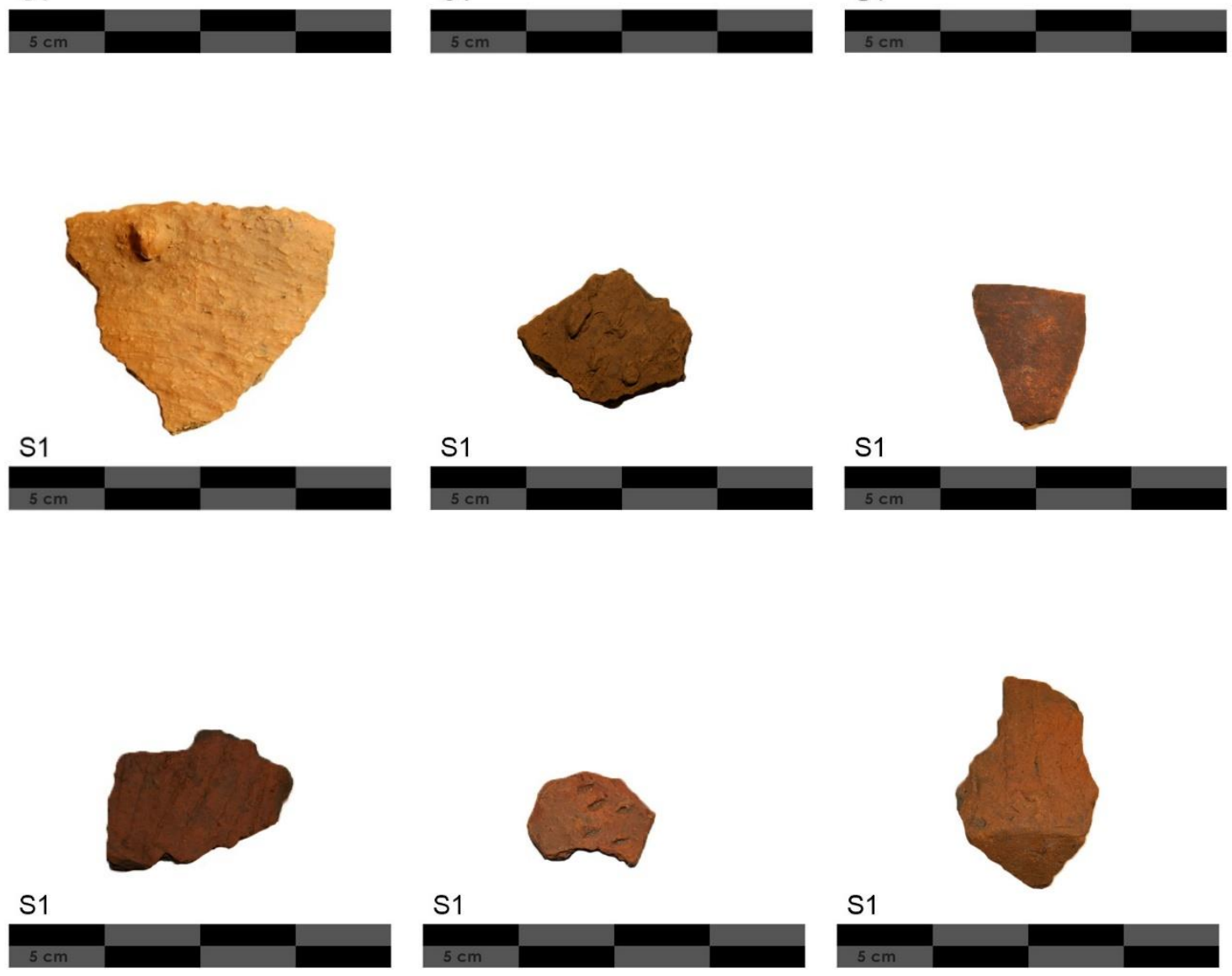

S1
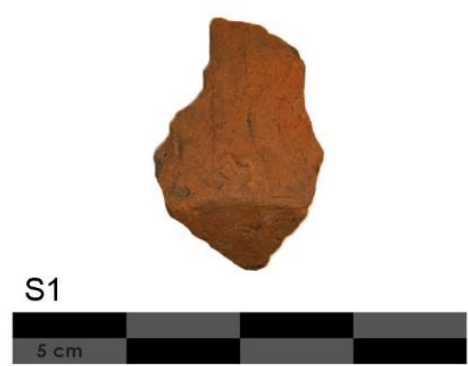

Tabla 70. Starčevačka keramika iz sonde I-2018 (snimio Dž. Brigić) 


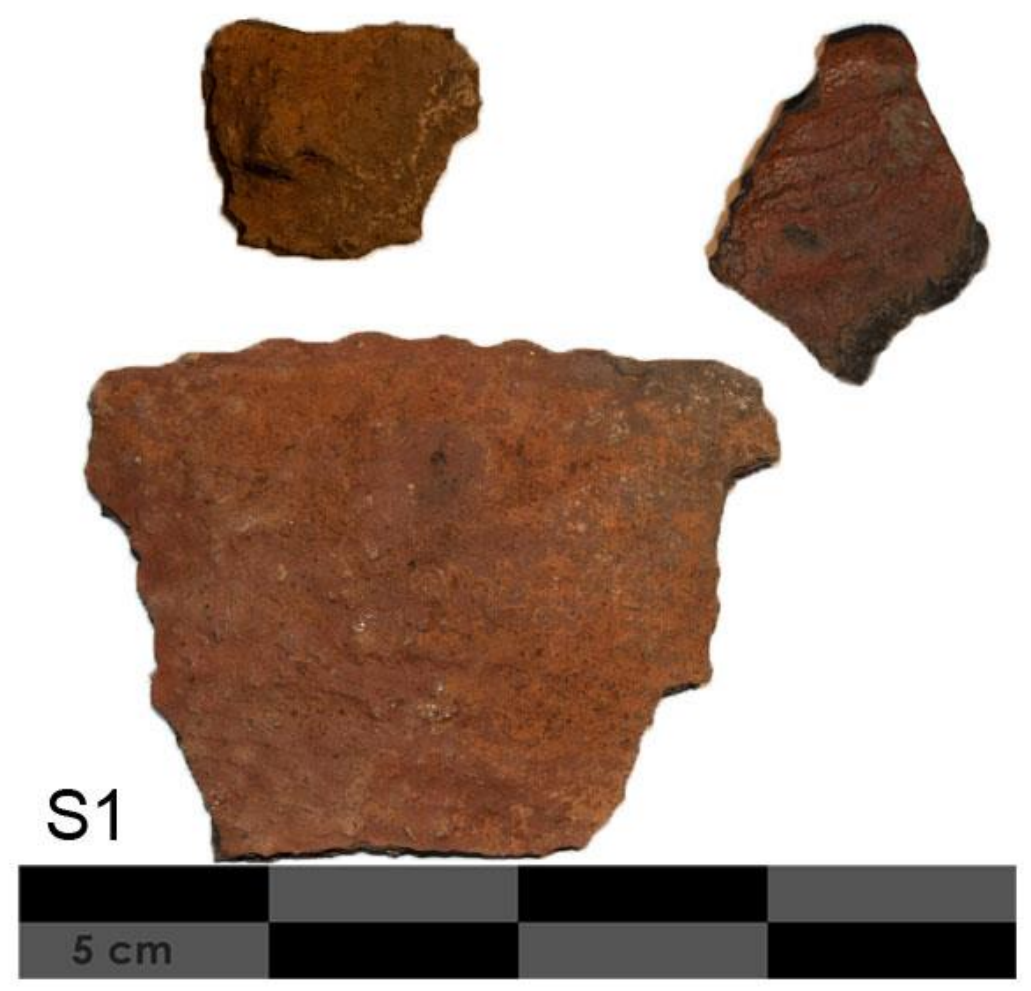

Tabla 71. Barbotin keramika starčevačkog tipa, dubina 1,68-1,80 m (snimio Dž. Brigić)

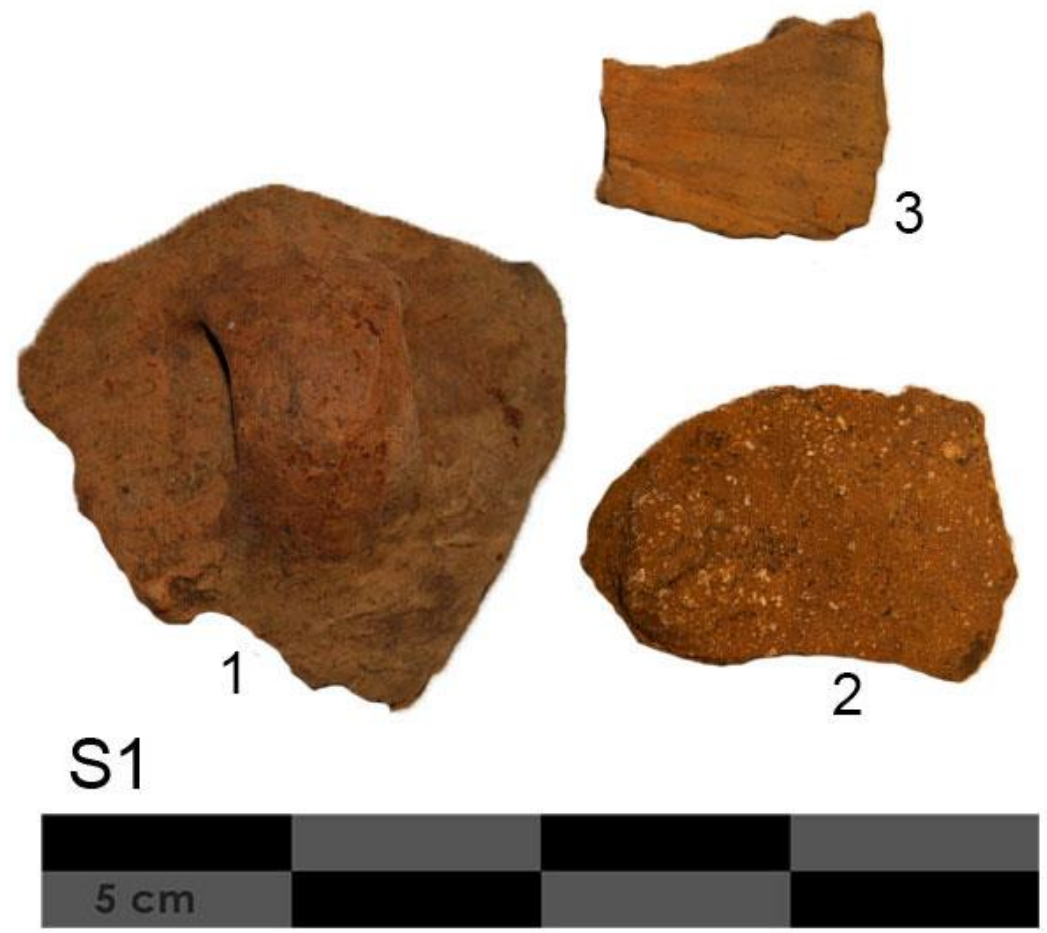

Tabla 72. Keramika sa manjom odnosno većom upotrebom krečnog pijeska, i urezana keramika, sonda I-2018, dubina 1,68 m (snimio Dž. Brigić) 


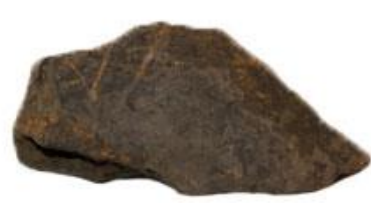

1

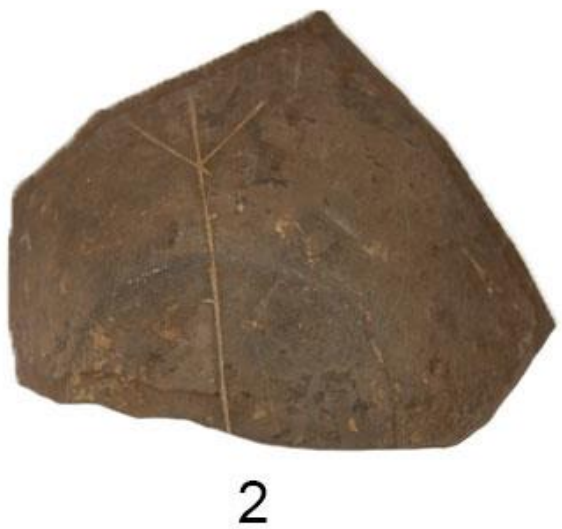

\section{S1}

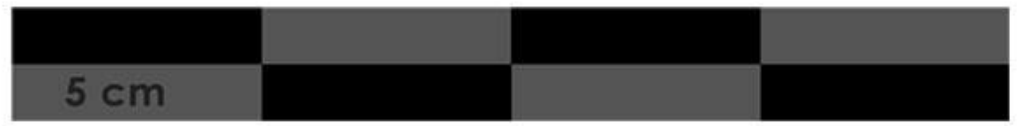

Tabla 73. Vinčanska keramika sa urezanim motivima (snimio Dž. Brigić)

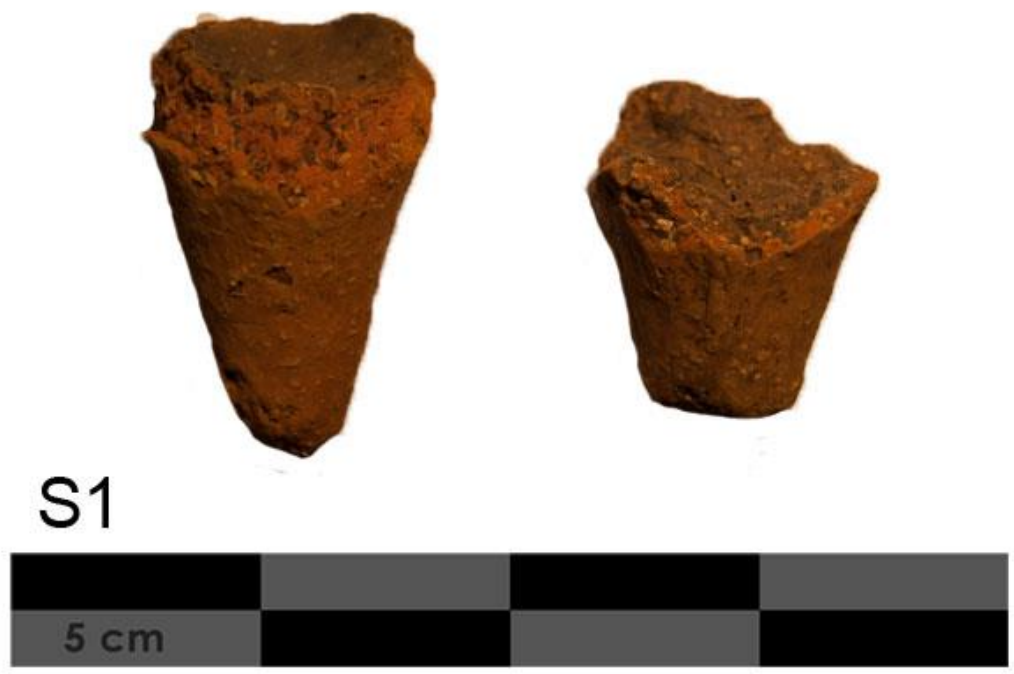

Tabla 74. Noge žrtvenika, sonda I-2018, dubina 1,30 m (snimio Dž. Brigić) 


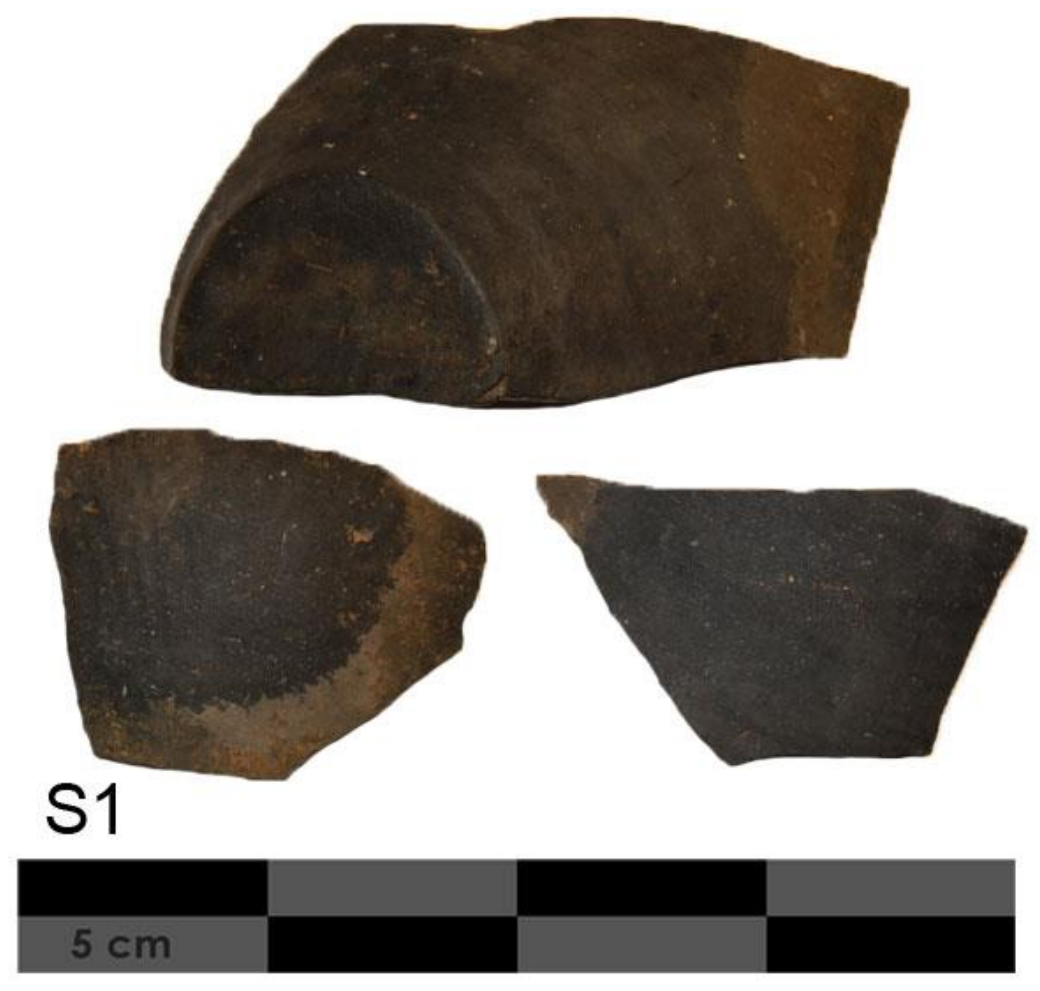

Tabla 75. Vinčanska keramika, sonda I-2018, dubina 0,85 m (snimio Dž. Brigić)
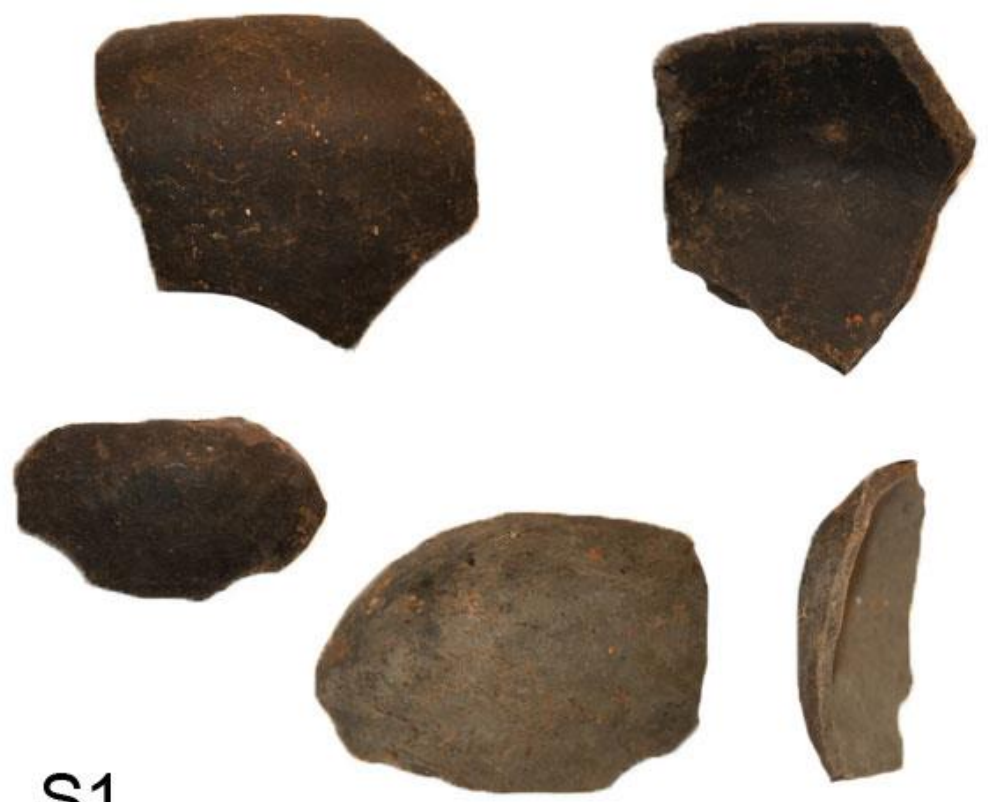

\section{S1}

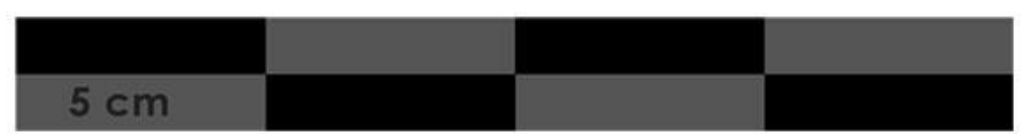

Tabla 76. Vinčanska keramika, sonda I-2018, dubina 0,80 m (snimio Dž. Brigić) 


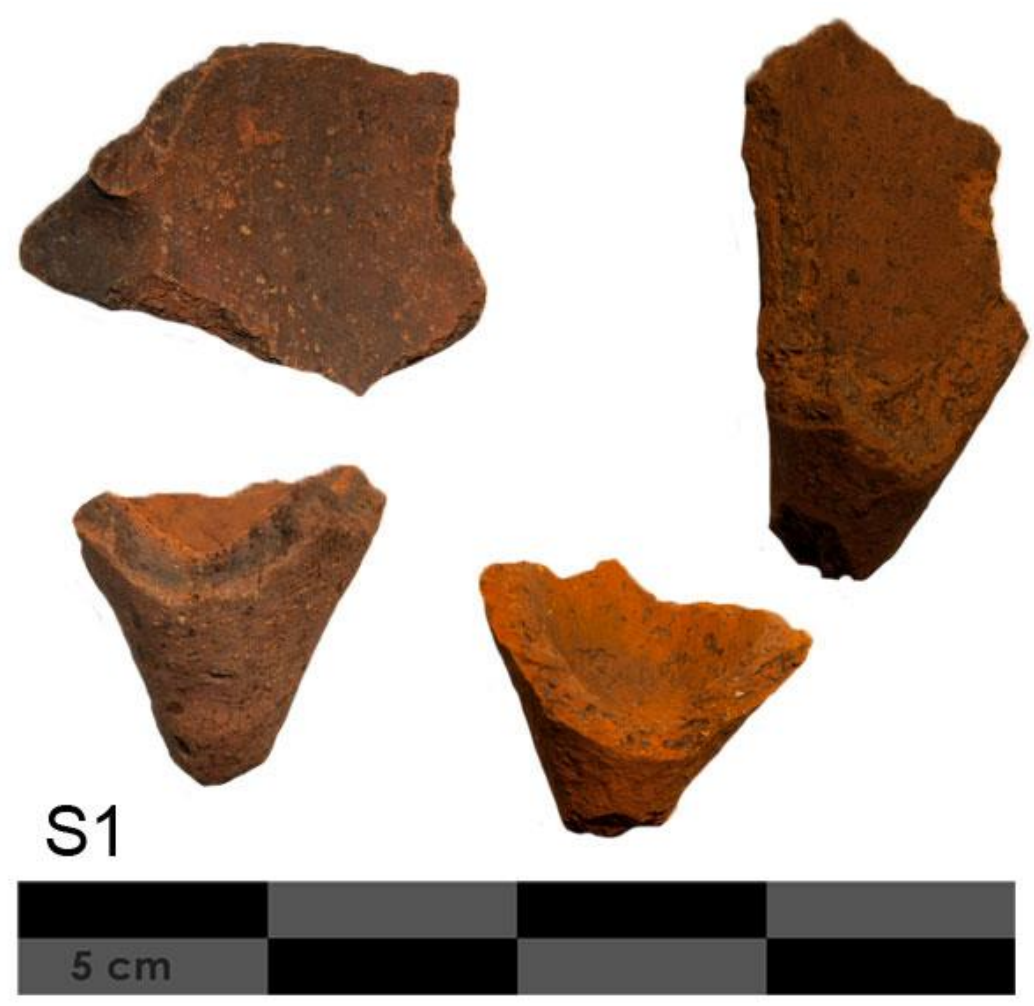

Tabla 77. Posude sa šiljatim dnom i lijevkom, sonda I-2018, dubina 0,80 m (snimio Dž. Brigić)
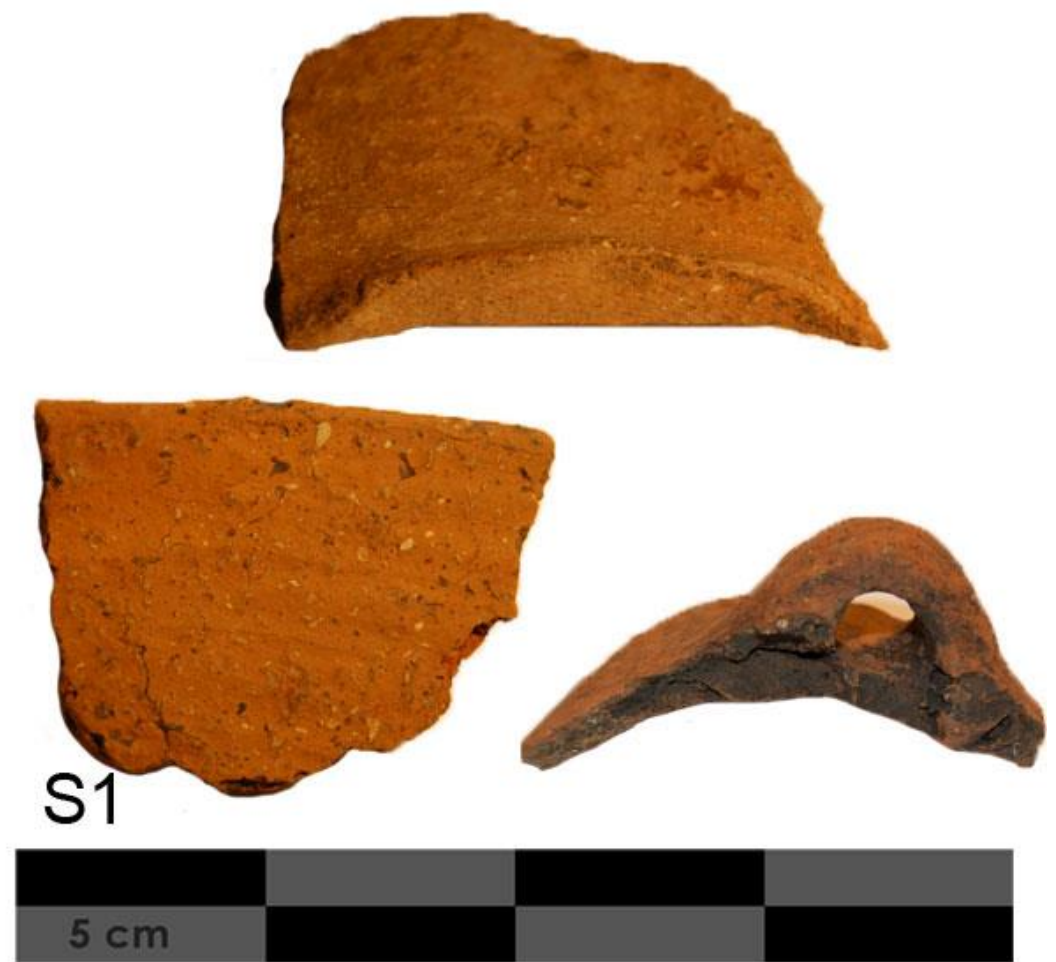

Tabla 78. Crvenkastosmeđa vinčanska keramika, dubina $0,80 \mathrm{~m}$ (snimio Dž. Brigić) 


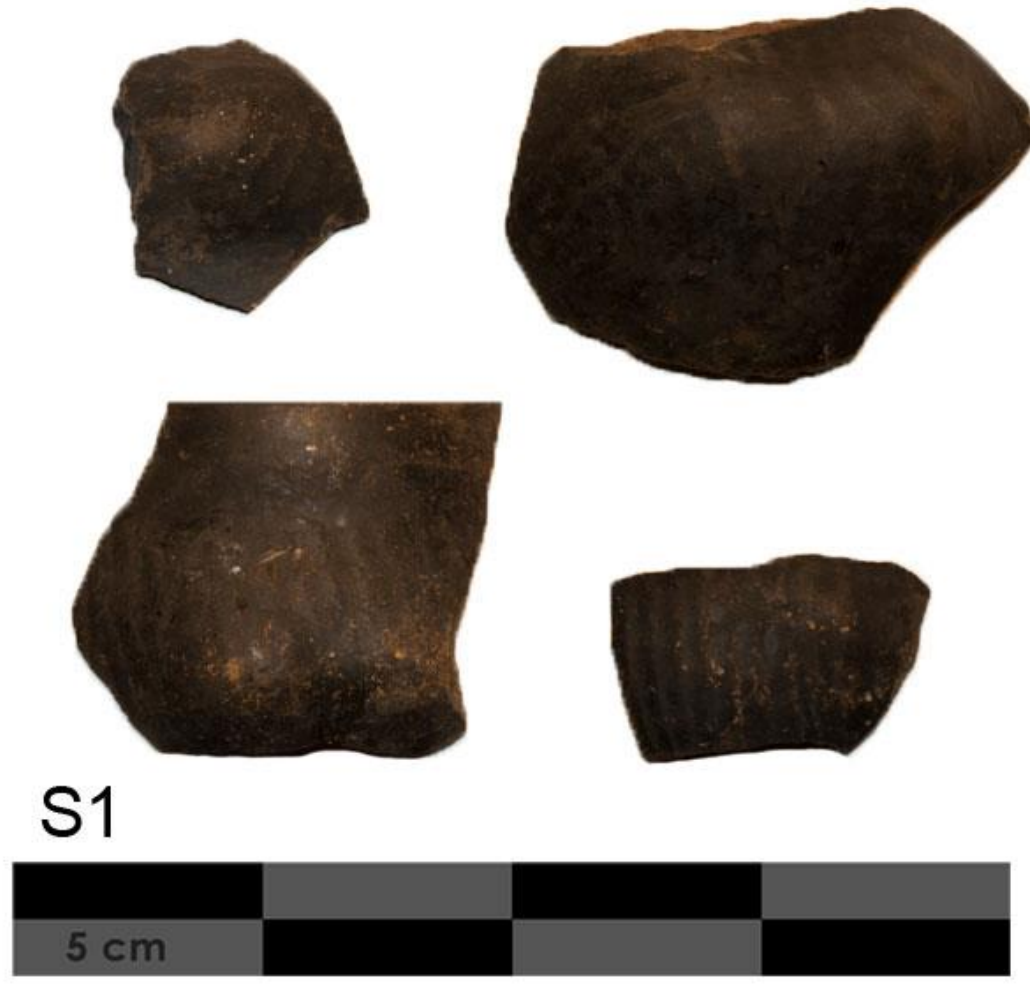

Tabla 79. Oblici vinčanske kulture, dubina 0,75 m (snimio Dž. Brigić)

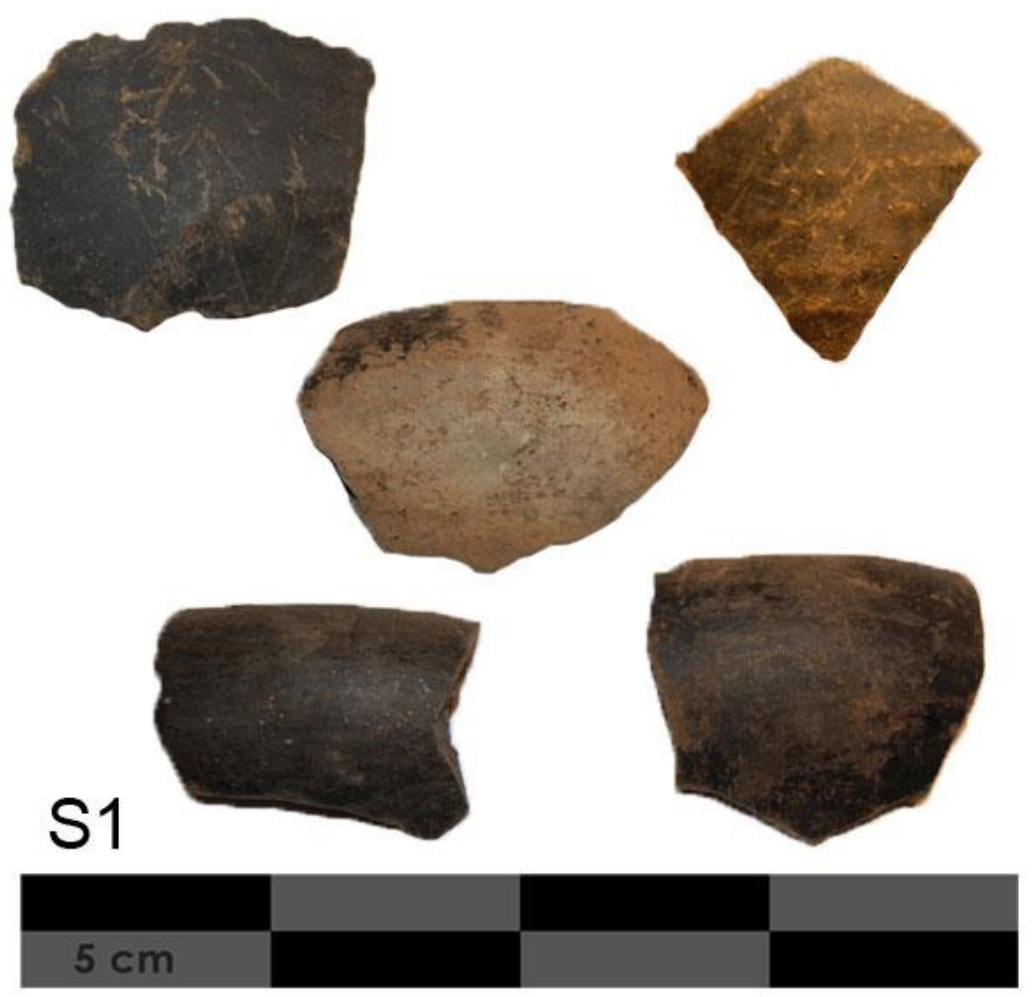

Tabla 80. Oblici vinčanske kulture, dubina 0,68 m (snimio Dž. Brigić) 

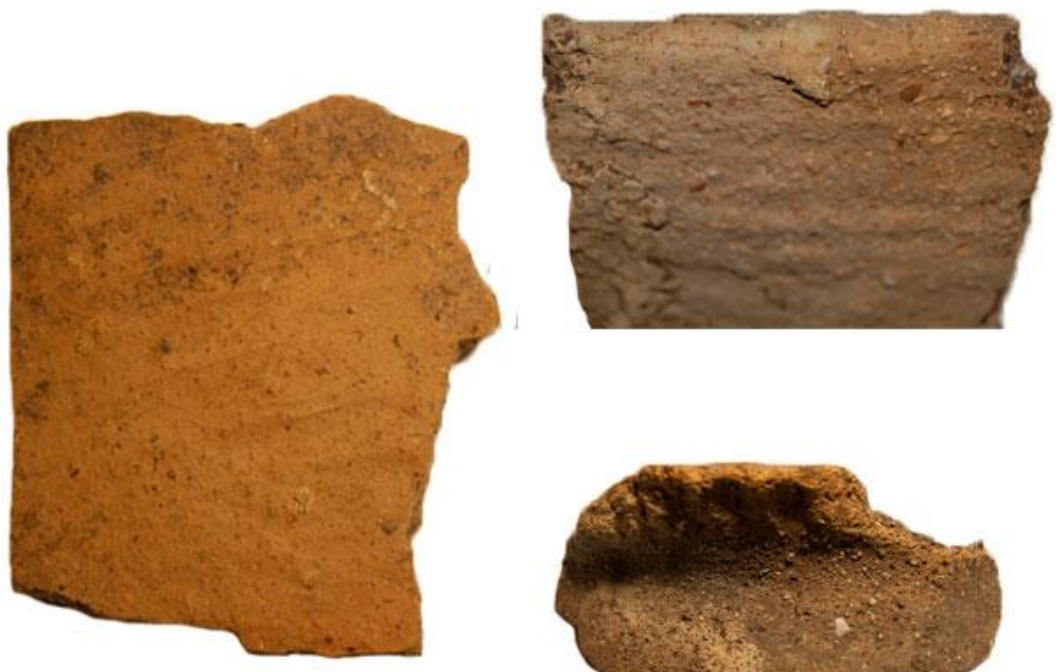

\section{S1}

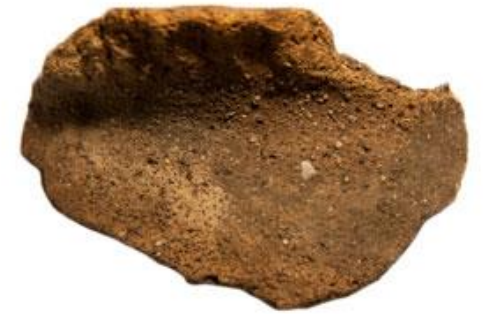

$5 \mathrm{~cm}$

Tabla 81. Gruba vinčanska keramika, dubina 0,68-0,75 m (snimio Dž. Brigić)

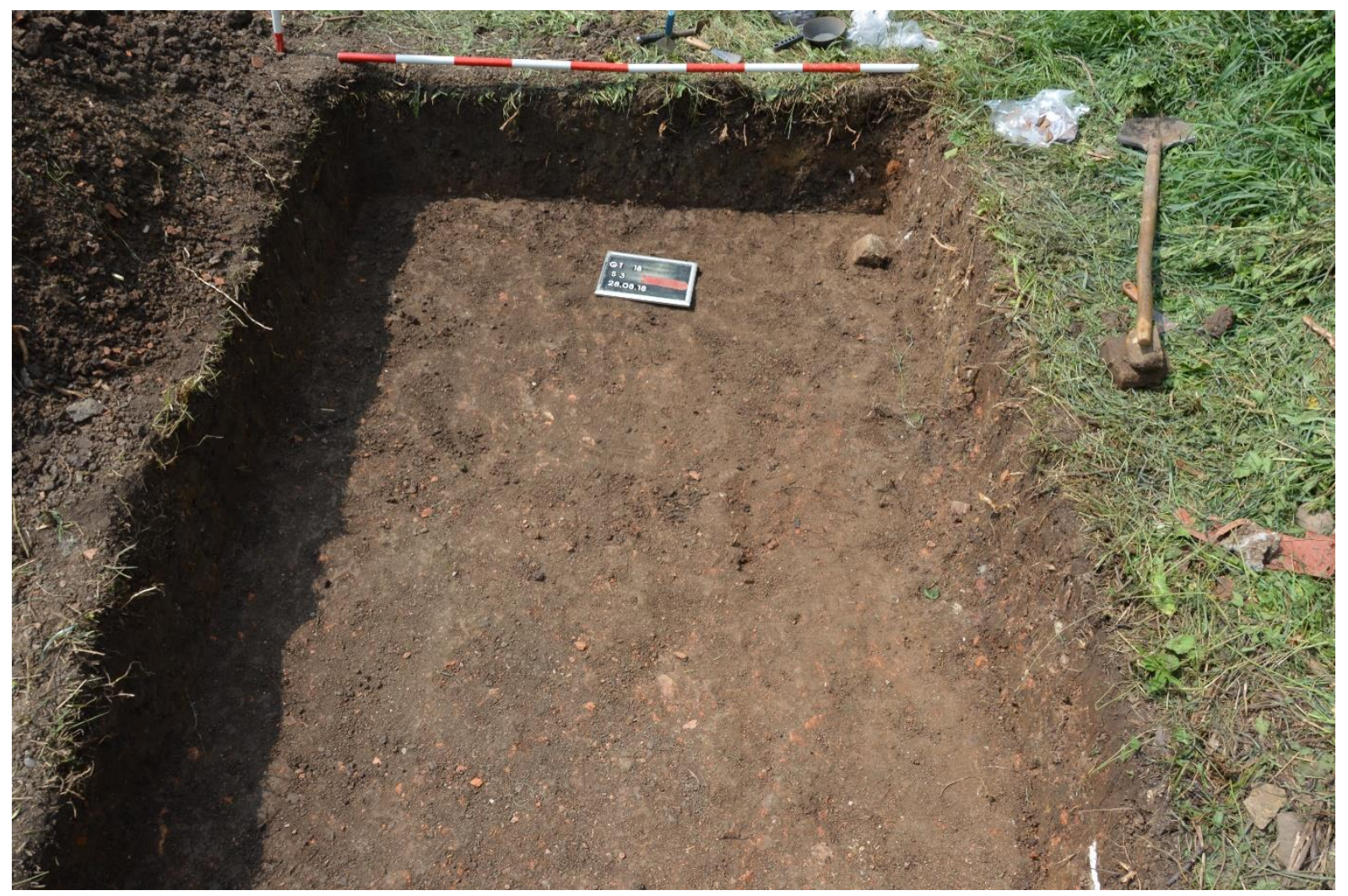

Tabla 82. Sonda III-2018 (snimila M. Turkmanović) 


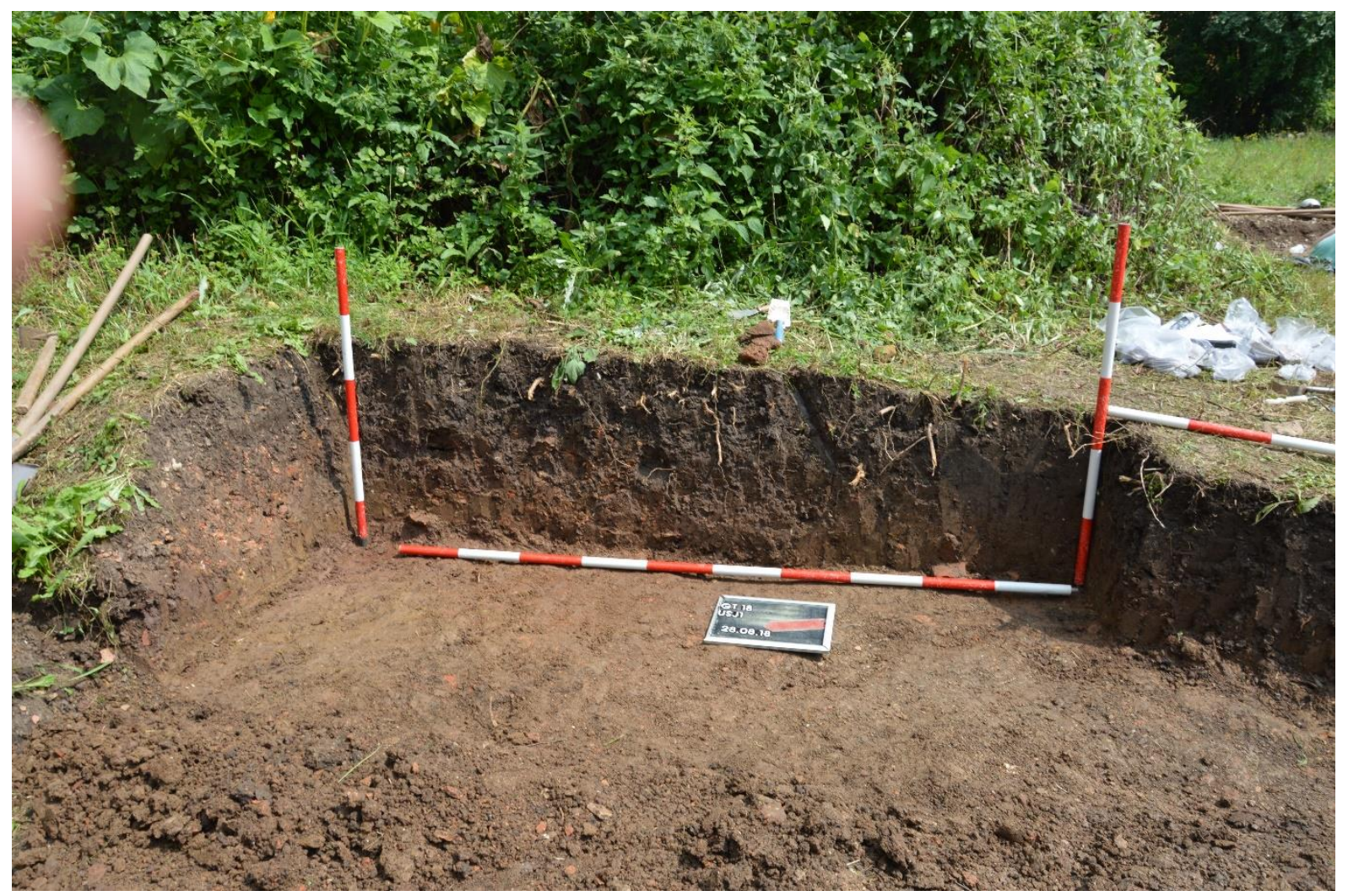

Tabla 83. Usjek 1-2018 (snimila M. Turkmanović)

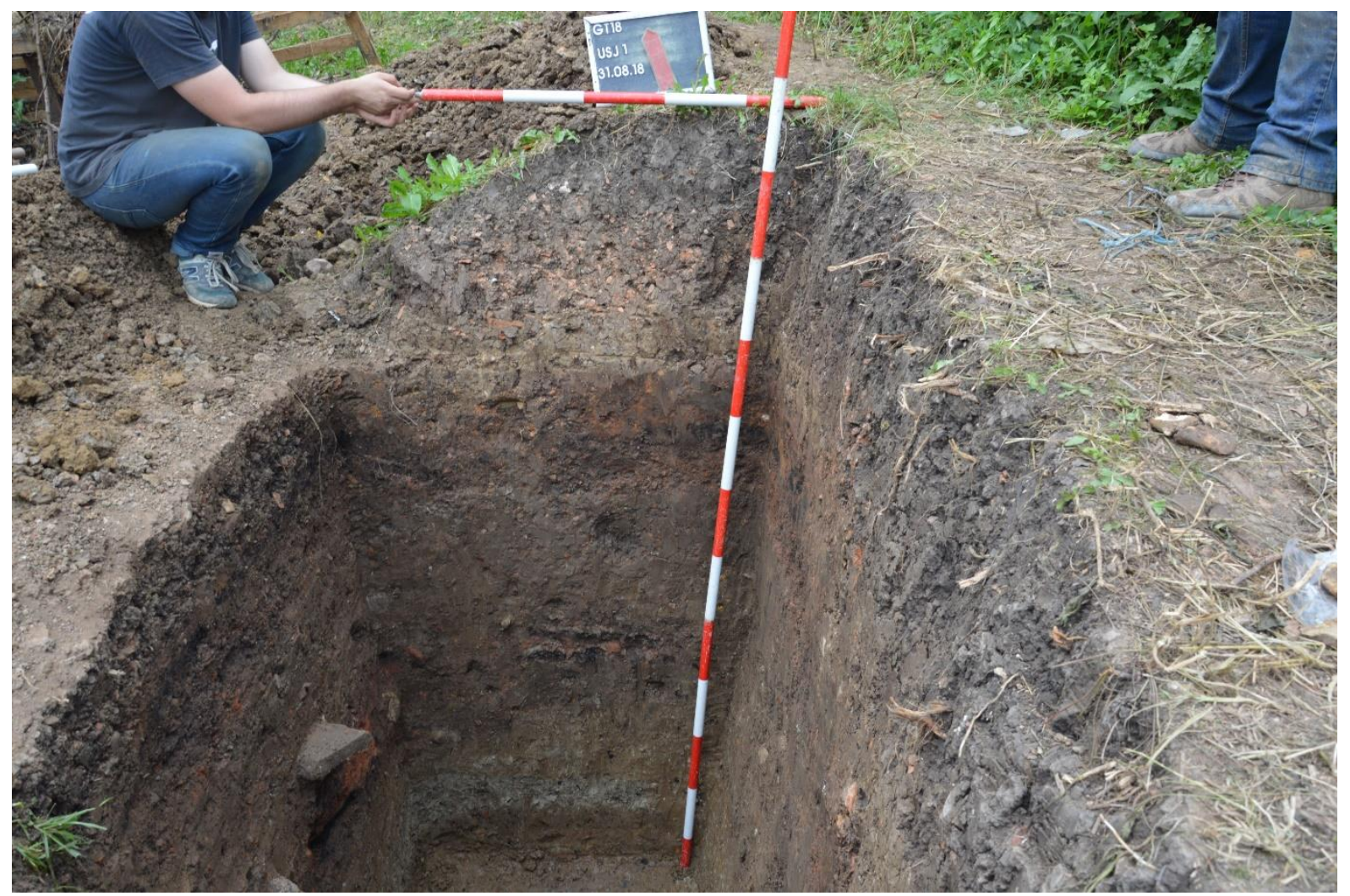

Tabla 84. Vertikalni profil usjeka (snimila M. Turkmanović) 

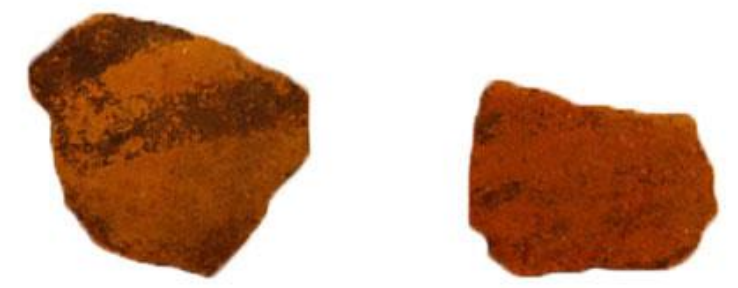

\section{USJ}

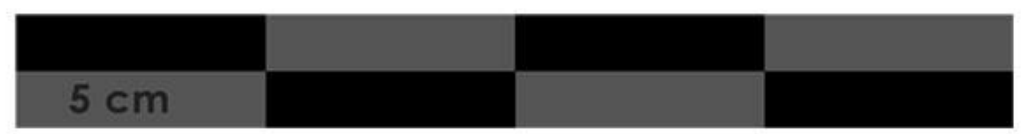

Tabla 85. Slikana keramika iz usjeka (snimila M. Turkmanović)
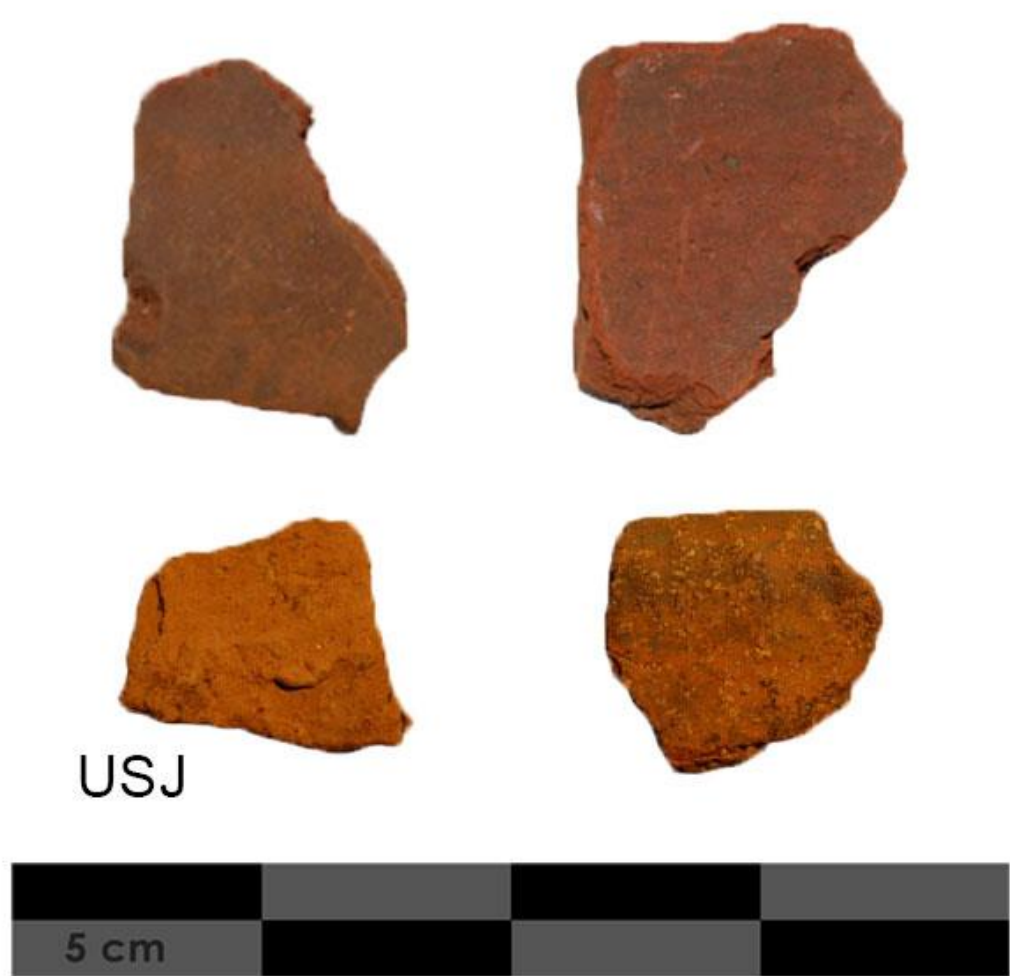

Tabla 86. Monohromna i barbotin keramika (snimio Dž. Brigić) 

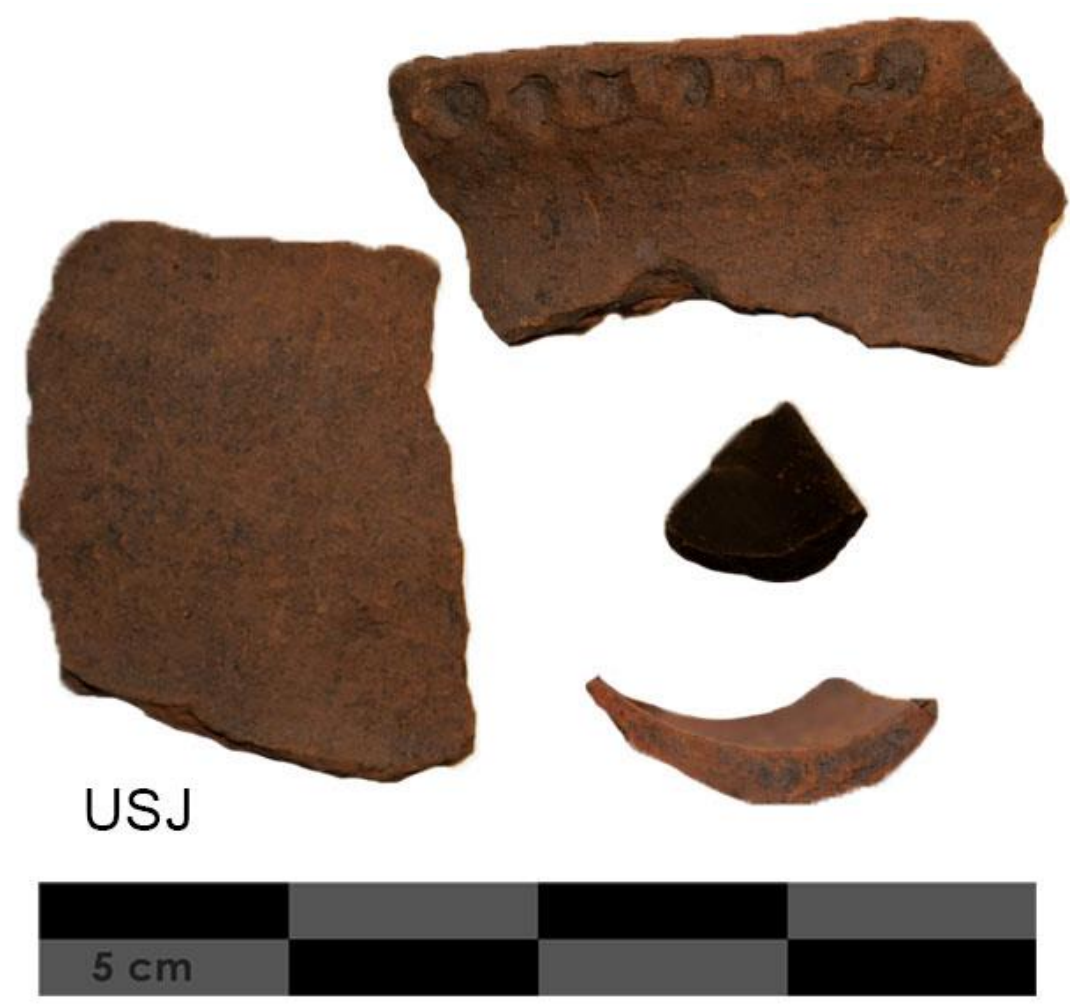

Tabla 87. Keramika ukrašena utiskivanjem prstiju i bikonični oblici (snimio Dž. Brigić)

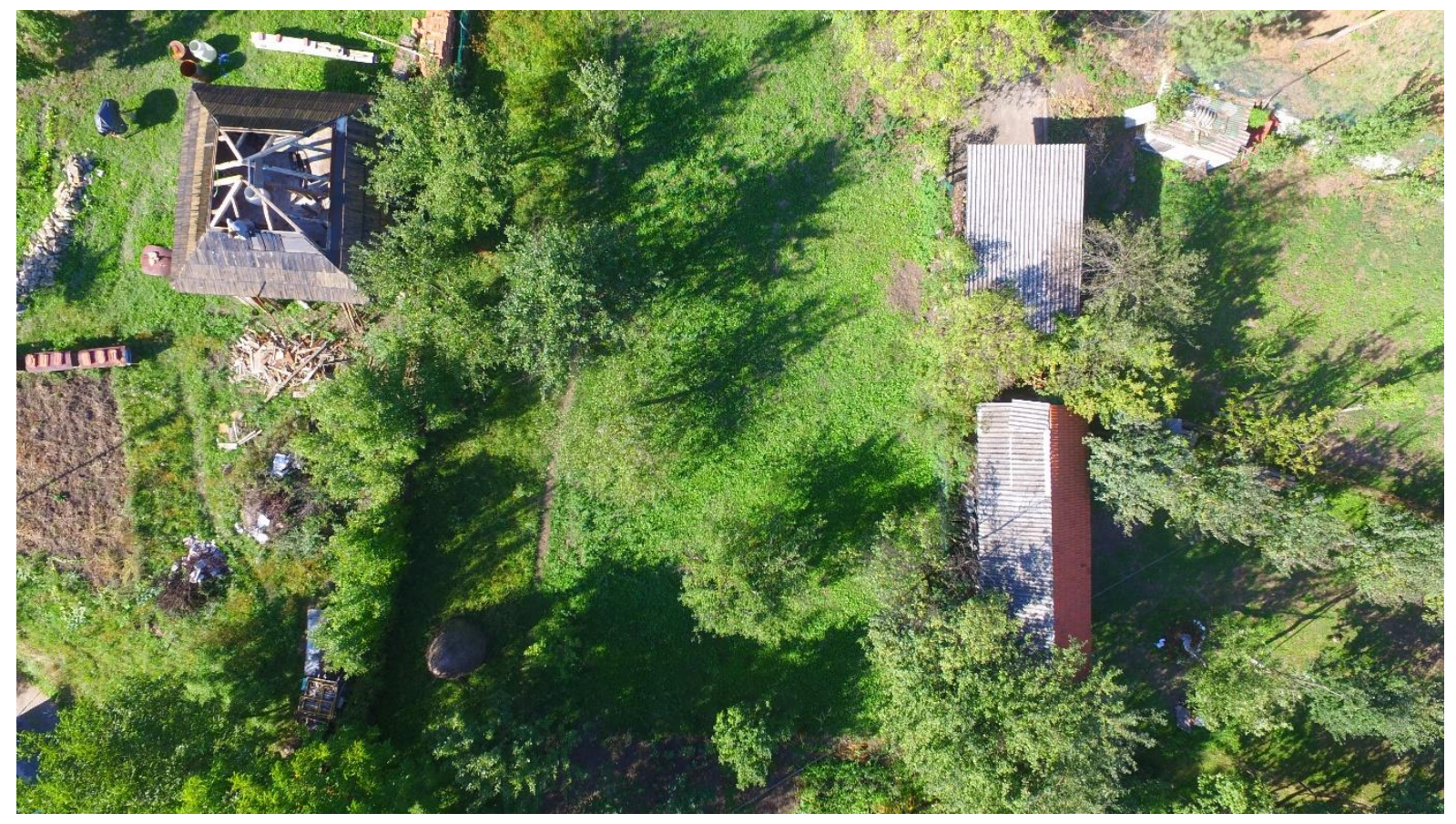

Tabla 88. Katastarska čestica 615 (snimio M. Burić) 


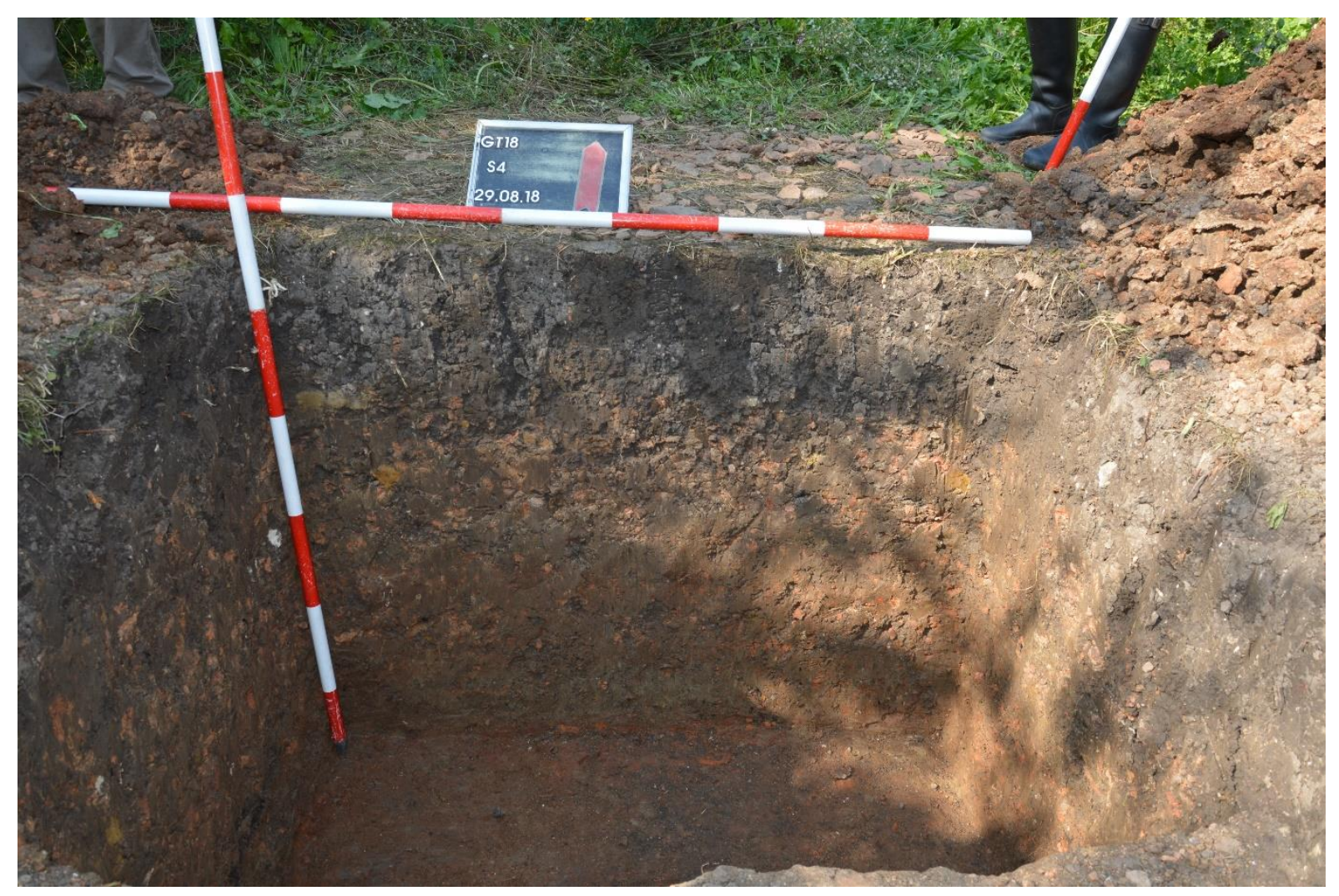

Tabla 89. Sonda IV-2018 (snimila M. Turkmanović)

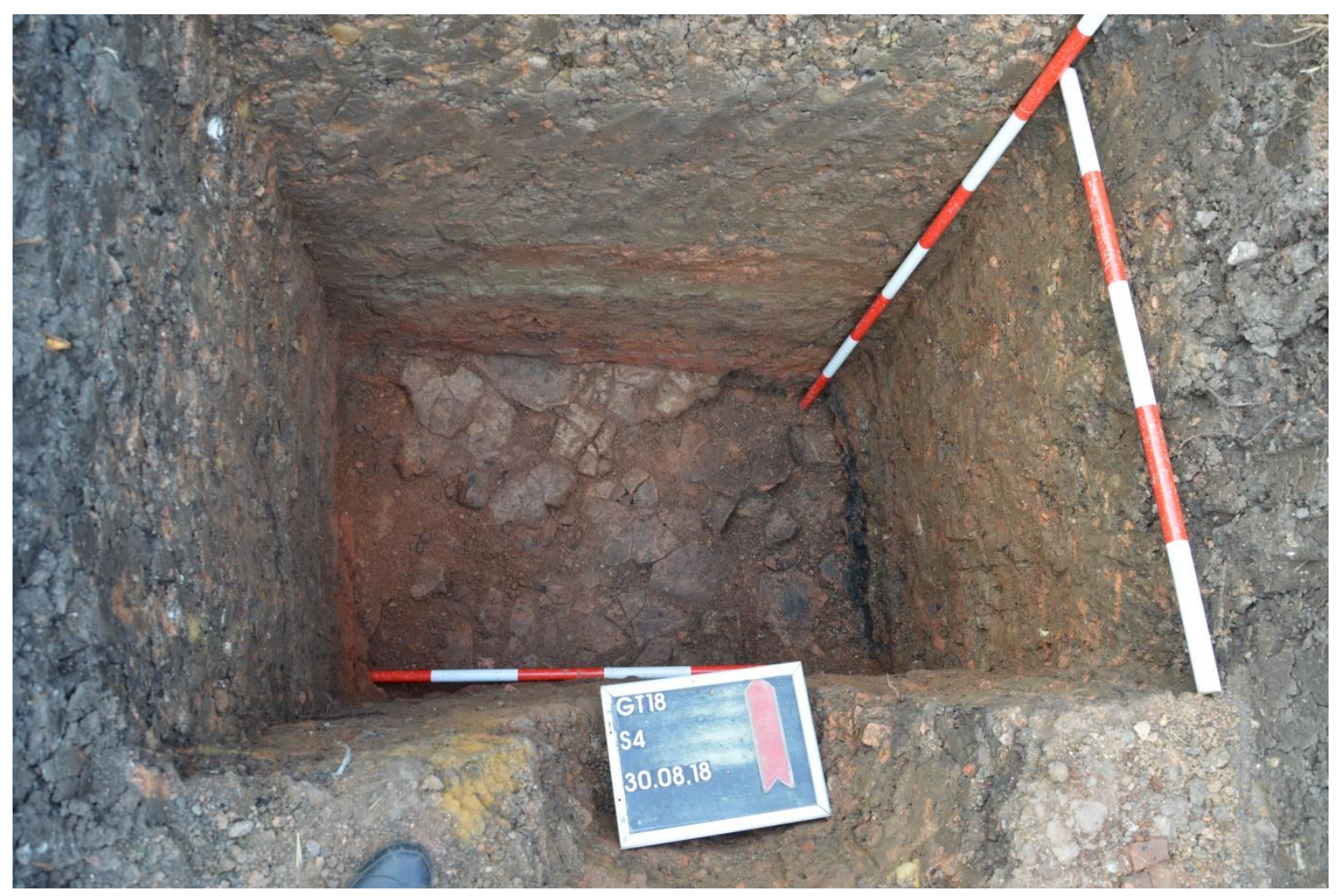

Tabla 90. Sonda IV-2018 (snimila M. Turkmanović) 


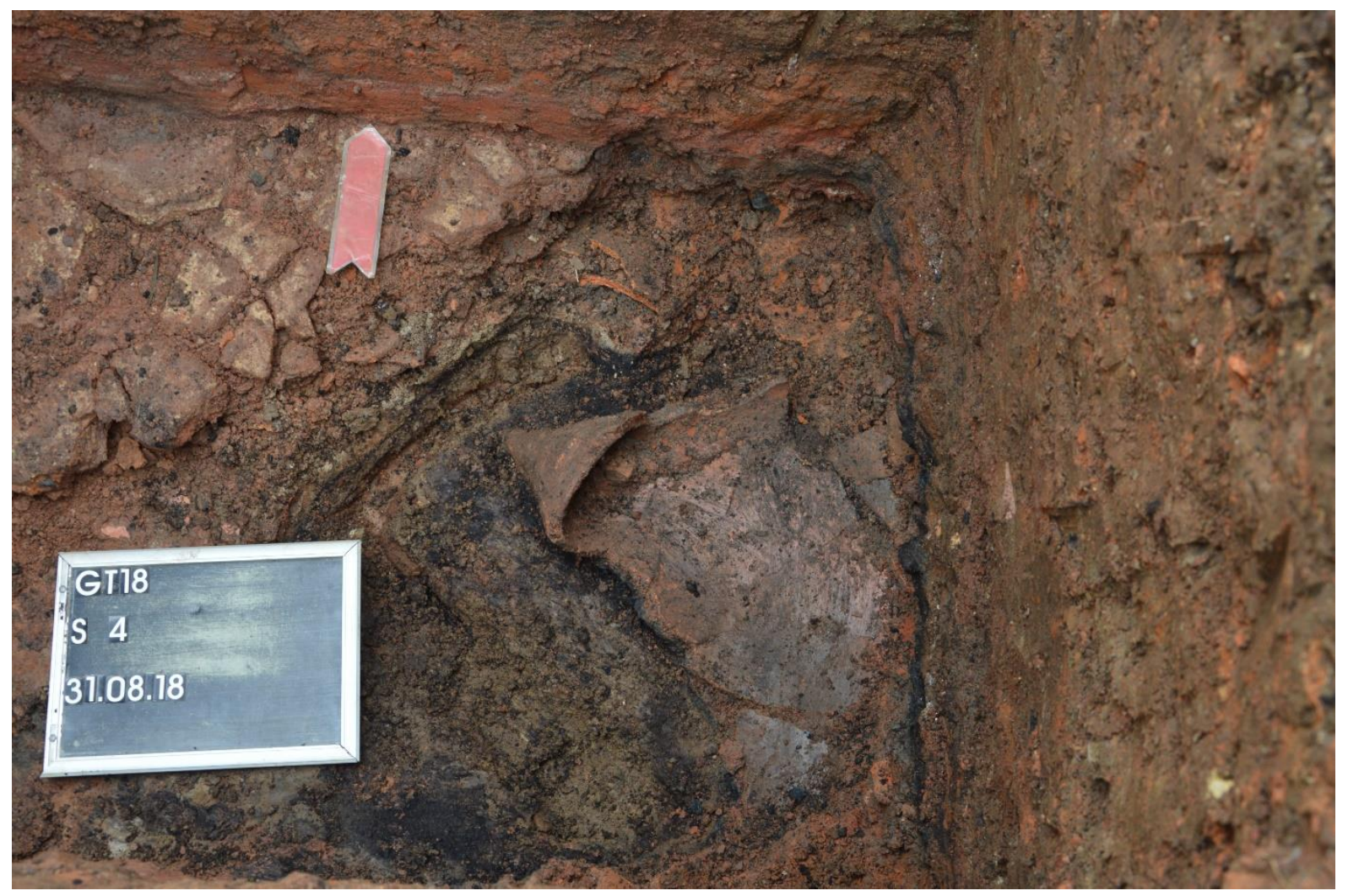

Tabla 91. Podnice i posuda sa šiljatim dnom, sonda IV, dubina 1,90 m (snimio Dž. Brigić)

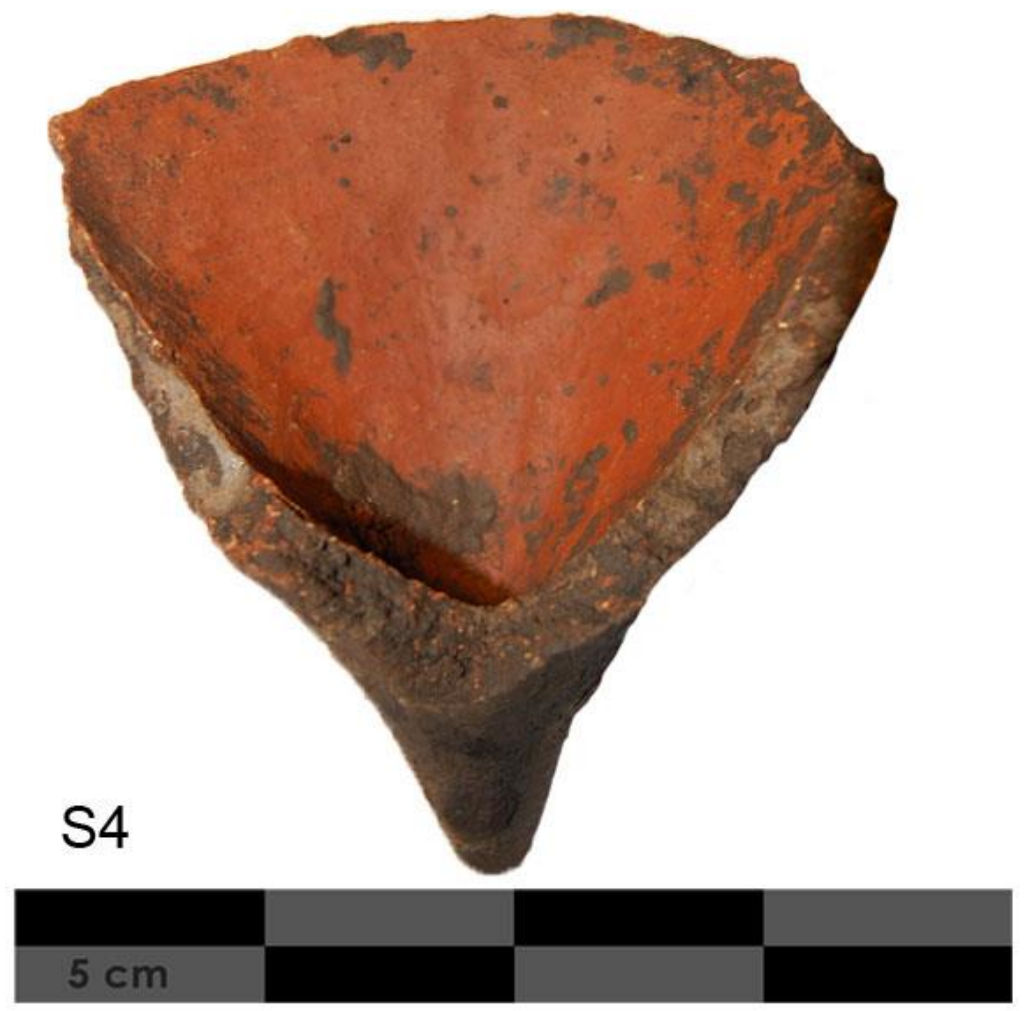

Tabla 92. Posuda sa šiljatim dnom, sonda IV (snimio Dž. Brigić) 


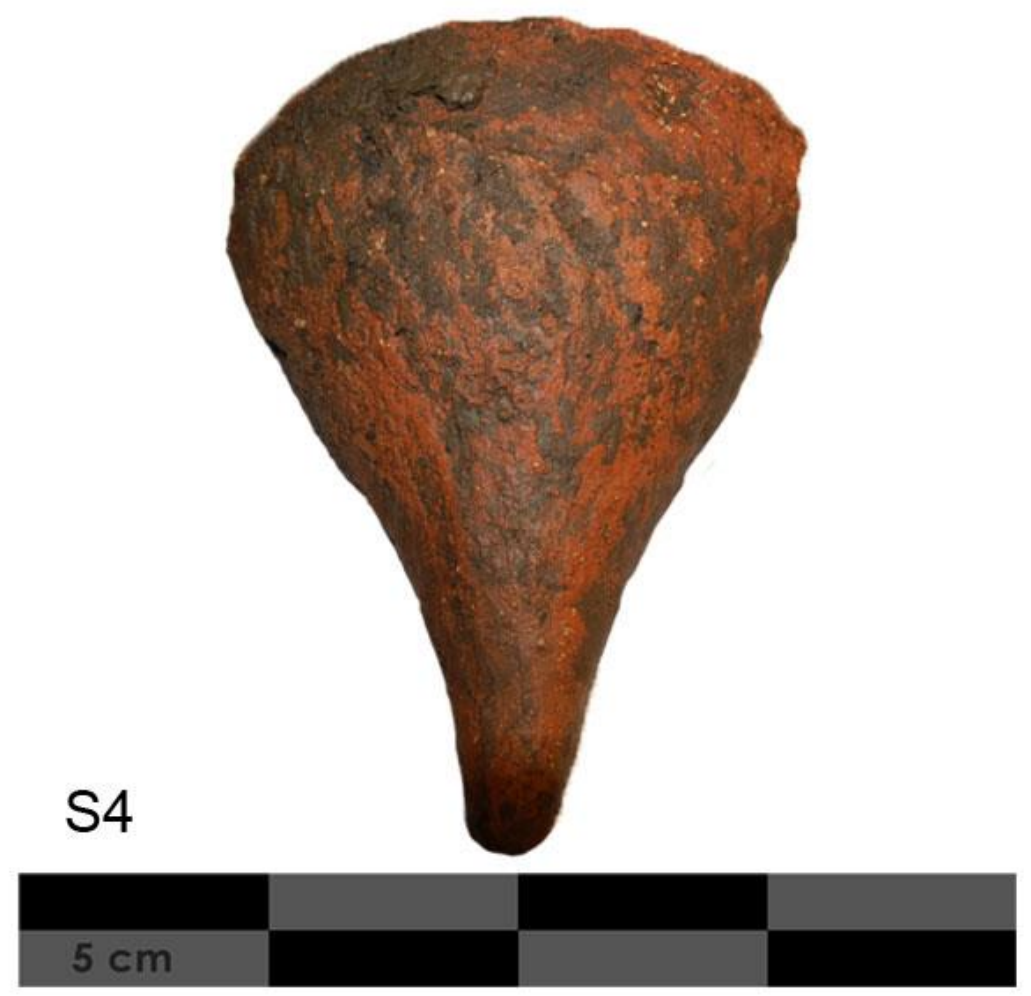

Tabla 93. Posuda sa šiljatim dnom, sonda IV (snimio Dž. Brigić)

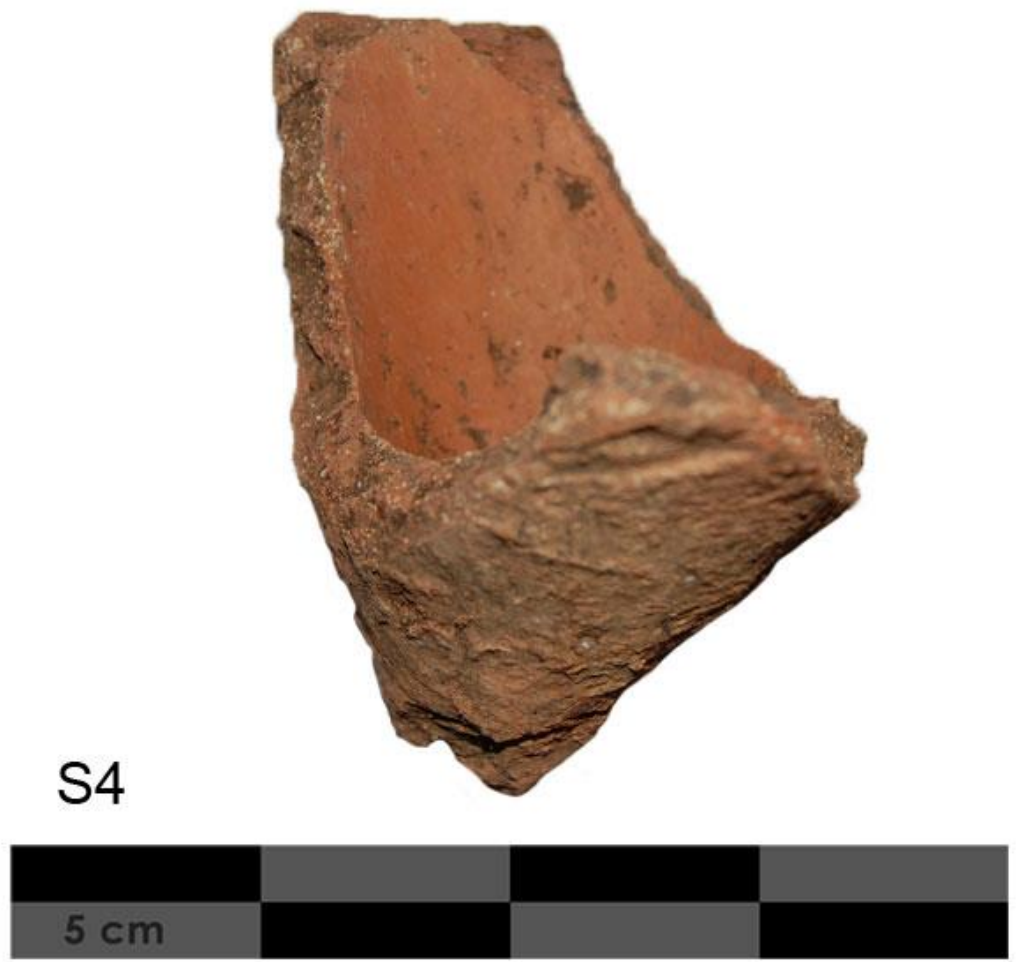

Tabla 94. Posuda sa zdepastijom nogom, sonda IV, dubina 1,70 m (snimio Dž. Brigić) 

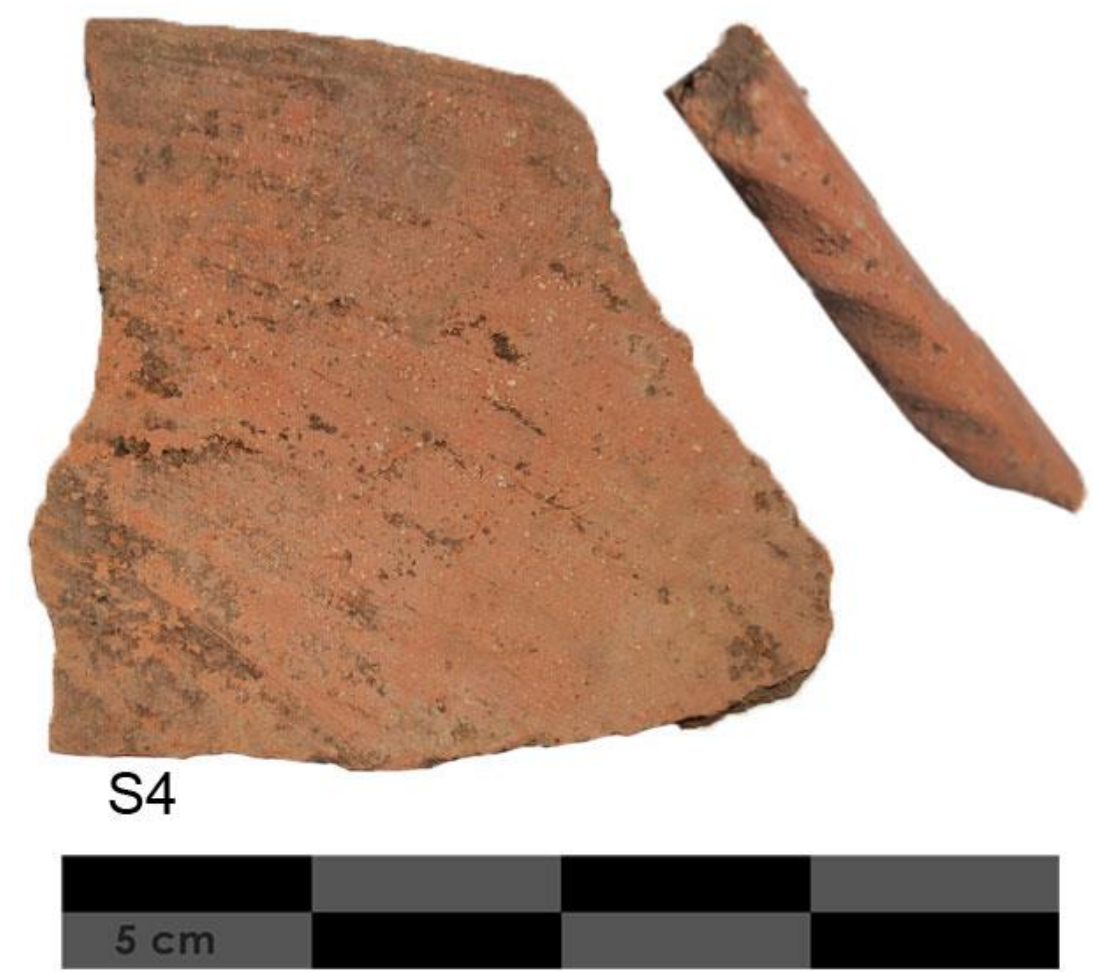

Tabla 95. Ornamenti posude sa šiljatom nogom, dubina 1,90 m (snimio Dž. Brigić)

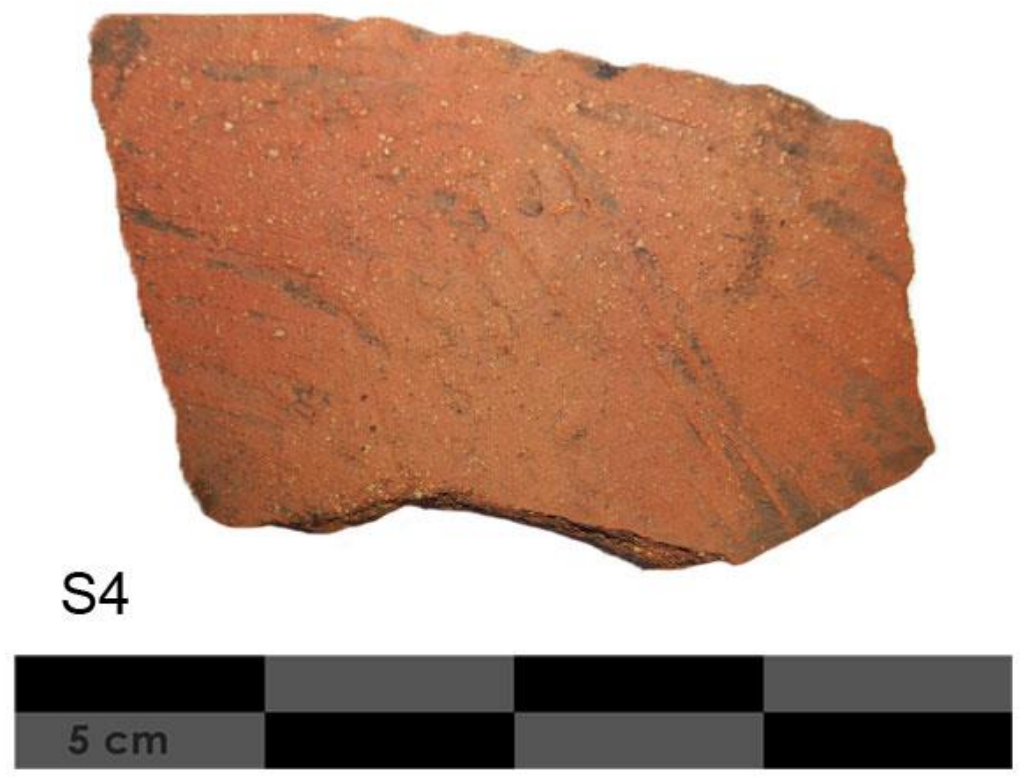

Tabla 96. Ornamenti posude sa šiljatom nogom, dubina 1,90 m (snimio Dž. Brigić) 


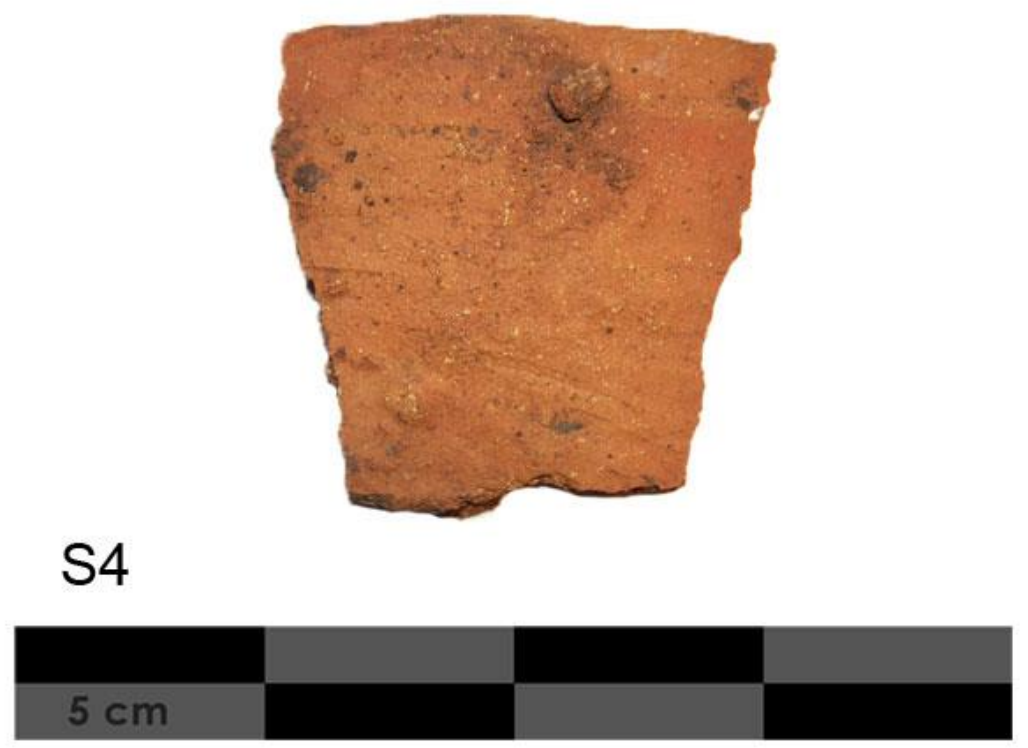

Tabla 97. Plastični naljepak na posudi sa šiljatim dnom, dubina 1,70 m (snimio Dž. Brigić)

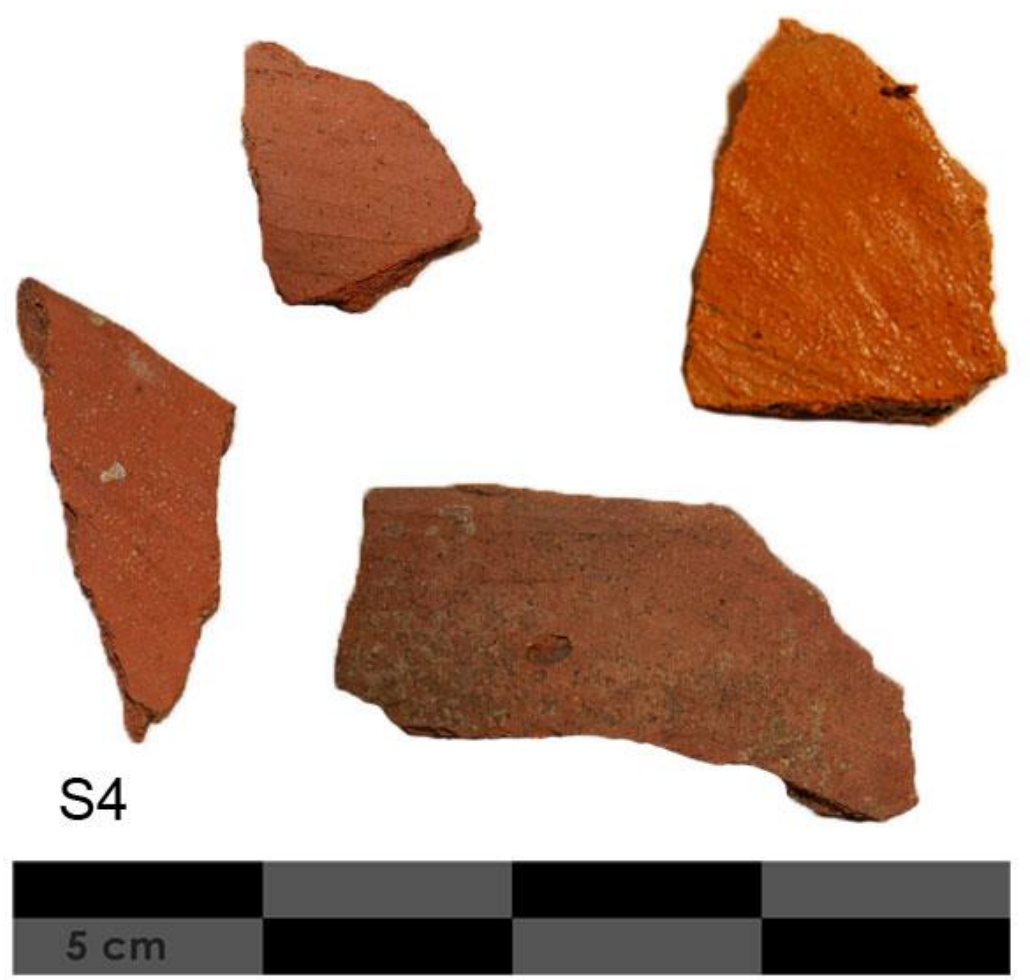

Tabla 98. Ornamenti posude sa zdepastom nogom, dubina 1,70 m (snimio Dž. Brigić) 


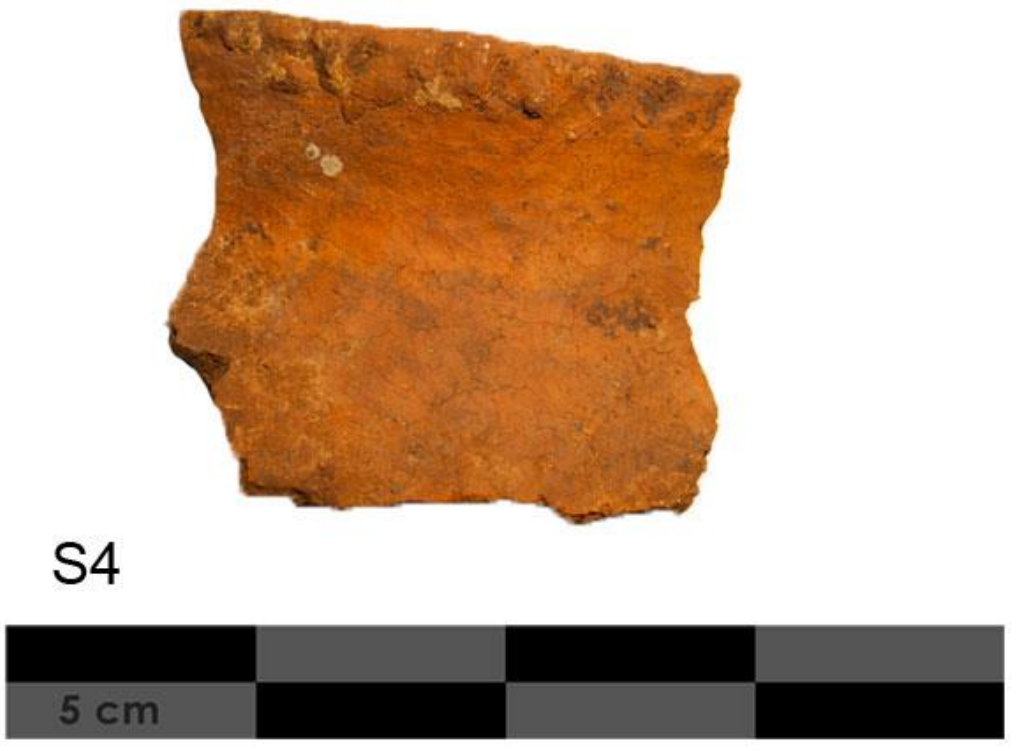

Tabla 99. Trbušaste posude sa izvraćenim obodom, dubina 1,63 m (snimio Dž. Brigić)

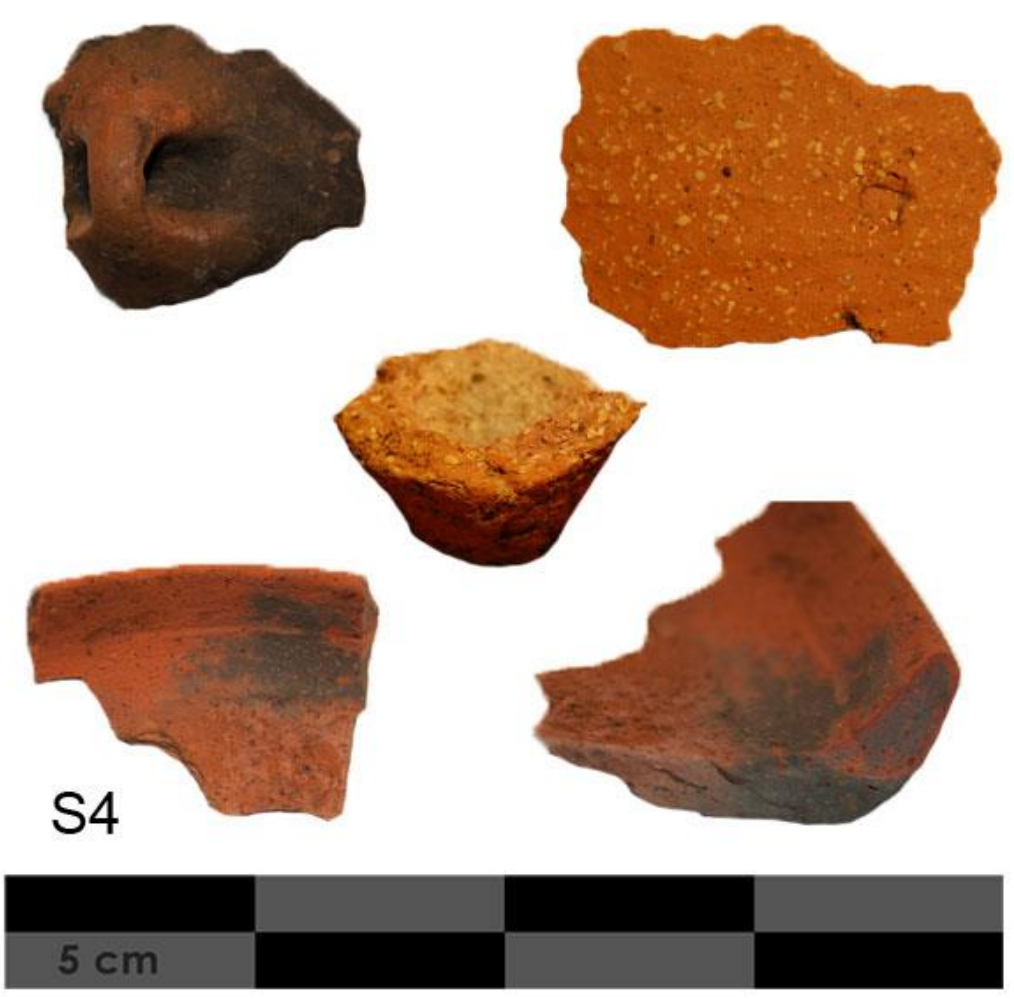

Tabla 100. Vinčanski oblici, sonda IV, sloj 5 (snimio Dž. Brigić) 


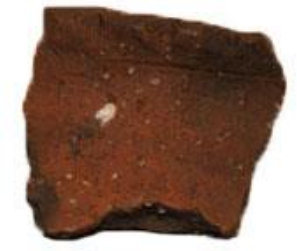

1

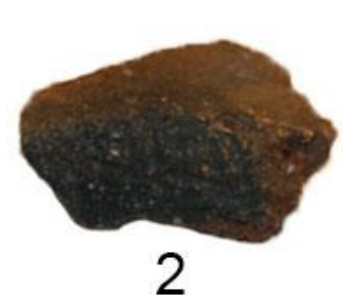

2

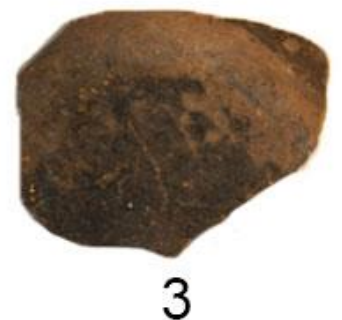

S4

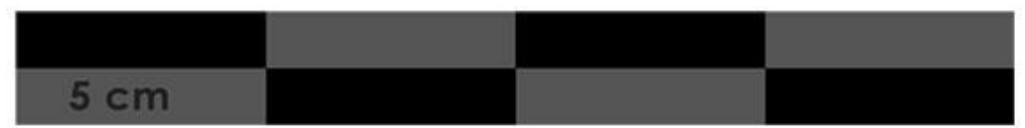

Tabla 101. Sl. 1 - trbušasta posudica; 2 i 3 - dno sa otiskom asure (snimio Dž. Brigić)

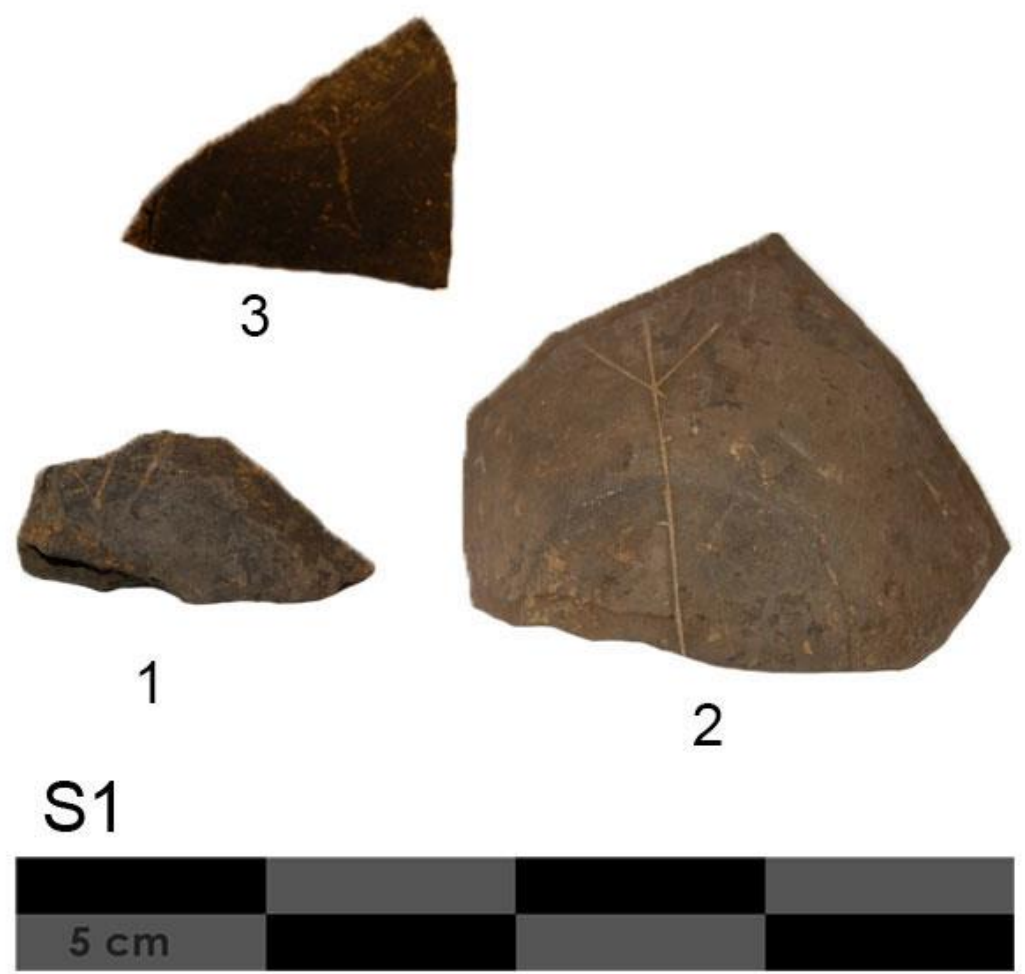

Tabla 102. Vinčanska keramika sa urezanim motivima: 1 - sonda I-2018; 2 - sonda II-1958; 3 sonda IV-2018 (snimio Dž. Brigić) 